University of Louisville

ThinkIR: The University of Louisville's Institutional Repository

Electronic Theses and Dissertations

$5-2014$

\title{
The ethos of conspiracy argument : "character" as persuader in conspiracy rhetoric.
}

Michael James Sobiech

University of Louisville

Follow this and additional works at: https://ir.library.louisville.edu/etd

Part of the English Language and Literature Commons

\section{Recommended Citation}

Sobiech, Michael James, "The ethos of conspiracy argument : "character" as persuader in conspiracy rhetoric." (2014). Electronic Theses and Dissertations. Paper 1359.

https://doi.org/10.18297/etd/1359

This Doctoral Dissertation is brought to you for free and open access by ThinkIR: The University of Louisville's Institutional Repository. It has been accepted for inclusion in Electronic Theses and Dissertations by an authorized administrator of ThinkIR: The University of Louisville's Institutional Repository. This title appears here courtesy of the author, who has retained all other copyrights. For more information, please contact thinkir@louisville.edu. 
THE ETHOS OF CONSPIRACY ARGUMENT:

"CHARACTER" AS PERSUADER IN CONSPIRACY RHETORIC

By

Michael James Sobiech

B.S., Indiana University, 1988

M.A., Western Kentucky University, 2008

\begin{abstract}
A Dissertation
Submitted to the Faculty of the

College of Arts and Sciences of the University of Louisville in Partial Fulfillment of the Requirements

for the Degree of
\end{abstract}

Doctor of Philosophy

Department of English

University of Louisville

Louisville, Kentucky

May 2014 
Copyright 2014 by Michael James Sobiech

All rights reserved 

THE ETHOS OF CONSPIRACY ARGUMENT:

"CHARACTER" AS PERSUADER IN CONSPIRACY RHETORIC

By

Michael James Sobiech

B.S., Indiana University, 1988

M.A., Western Kentucky University, 2008

A Dissertation Approved on

April 14, 2014

by the following dissertation committee

Debra Journet

Dissertation Director

Bronwyn Williams

Carol Mattingly

Susan Griffin

Marilyn Cooper

ii 


\section{DEDICATION}

\section{To my parents,}

Margaret and Andrew Sobiech.

I am thankful that God let me be your son. 


\section{ACKNOWLEDGMENTS}

This is not a perfect dissertation, but it has been made so much better by the help of so many. A very special thanks to my wonderful director, Debra Journet, who has been helping graduate students through the challenges of dissertations for over twenty years. I am so thankful that she took me on as one of her last students. Thank you to all the members of my committee, Debra Journet, Bronwyn Williams, Carol Mattingly, Susan Griffin, and Marilyn Cooper. Although I can be verbose (see the following dissertation), I am at a loss to adequately state how much I appreciate all your time, insight, encouragement, support, and help throughout this long project. Had I done it by myself, it would have been an utter wreck-picture the Hindenburg landing on the deck of the Titanic. I hope, some day, to emulate your qualities in my own teaching and research.

Thank you to all those at Western Kentucky University who helped set me on this path through their help in my receiving my MA, including Dale Rigby, who served as the director for my thesis, and Jane Olmsted, who helped me get a start in studying conspiracy rhetoric by letting me teach a class on conspiracy theories and pop culture.

Thank you to the University of Louisville's libraries, in particular the Interlibrary Loan department and Robert Detmering — both have been invaluable in doing this project. Thank you, also, to Joanna Wolfe (for whom I worked as an assistant director of composition), Susan Griffin (for whom I worked as a research assistant), and Joanne Webb (for whom I worked as an editorial assistant at the Henry James Review). 
Thank you to Karen Kopelson and Susan Ryan, who have been so helpful to me (and so many others) during their time as the director of graduate studies, and thank you to Beth Boehm, who has served as the dean of graduate studies. Thank you to Linda Baldwin and the English department staff. Thank you to my students here at the University of Louisville.

And thank you to my friends here at school, upon whom I could always depend in so many ways during the beautiful slogfest that is graduate school. This is not an exhaustive list, but special thanks to Chris Alexander, Lisa Arnold, Nancy Bou Ayash, Alicia Brazeau, Laura Detmering, Jason Dietz, Matthew Dowell, Harley and Gabi Ferris, Lauren Hall, Becky Hallman, Brittany Kelley, Carrie Byars Kilfoil, Tika Lamsai, Brice and Abby Nordquist, Rodrigo Martini Paula, Kathryn Perry, Caleb Pittman, Melissa Ratliff, Vanessa and Mike Sohan, Ryan Trauman, Simon Sangpukdee, Stephanie Weaver, Ben Wetherbee, Matthew Wiles, and Caroline Wilkinson.

I would also like to thank my church family here in Louisville, in particular Larry and Joan Coffey, Paul and Wilma Earnhart, Brock and Brittany Henry, Mark and Teresa McCrary, and the members of the Wednesday night supper club. Additionally, thanks to David and Ann Moses of Nashville, Tennessee.

And finally, a special thanks to my siblings, nieces, and nephews: Steve, Kathleen, Helen, Joseph, and John Paul Sobiech; Mary Ann, Brad, Drew, and Erin Barrett; Paul, Karin (McGowan), Anya, Eli, Ian, and Mila Sobiech. One of God's best gifts is taking those whom parents have to separate on long car rides and turning them into friends you wouldn't want to live without—and I have been so blessed. 


\title{
ABSTRACT \\ THE ETHOS OF CONSPIRACY ARGUMENT: \\ "CHARACTER" AS PERSUADER IN CONSPIRACY RHETORIC
}

\author{
Michael James Sobiech
}

April 14, 2014

Conspiracy theory has, as Timothy Melley states in Empire of Conspiracy

(2000), "animated our political culture from the early Republican period to the present, at times powerfully swaying popular opinion" (vii). Though it has attracted attention from a wide range of disciplines, conspiracy theory has not received significant notice within rhetoric and composition. My dissertation adds to the interdisciplinary body of scholarship concerning conspiracy theory by examining it as rhetoric, focusing on how the construction of a conspiracy proponent's ethos/character affects the persuasiveness of a conspiracy theory. I argue that ethos construction plays a much more significant role in conspiracy persuasion than typically considered.

In "The Paranoid Style in American Politics" (1964), Richard Hofstadter describes the importance played by "the figure of the renegade from the enemy cause" (such as an ex-Mormon or ex-nun) in American conspiracy argument. This dissertation examines the ethos of one prominent "renegade" - Charles Chiniquy (1809-1899), an ex-Catholic priest whose conspiracy charges were extensively used by anti-Catholics during America's Gilded Age and into the twenty-first century. I use as a case study Chiniquy's 1885 autobiography Fifty Years in the Church of Rome, in which he claims that President Lincoln spoke with him about the Catholic Church's covert working for the Confederacy and the Church's desire to assassinate Lincoln. With Lincoln as witness, Chiniquy's conspiracy was widely circulated to promote anti-Catholicism. 
Belief in Chiniquy's tale about the dead president ultimately depended on belief in the ex-priest; thus, my dissertation uses Chiniquy's ethos construction as a means of examining the role ethos plays in persuading people to accept extreme claims.

Chapter One reviews scholarship concerning ethos, anti-Catholicism, conspiracy rhetoric, and Chiniquy, my dissertation's principal historical and theoretical approaches. Chapter Two explores how Fifty Years constructs ethos for Chiniquy. Chapter Three examines how the purported Catholic plot against the president and the Union were constructed in Fifty Years to support an anti-Catholic message, concentrating on three themes which have implications concerning ethos in conspiracy narratives. And Chapter Four describes the reception of Chiniquy's conspiracy from the Gilded Age to the age of the World Wide Web. 


\section{TABLE OF CONTENTS}

\section{PAGE}

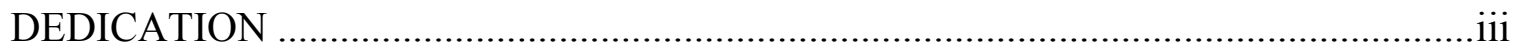

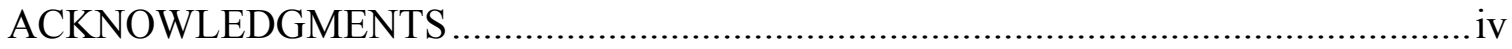

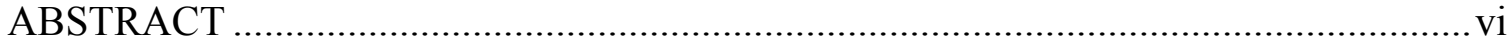

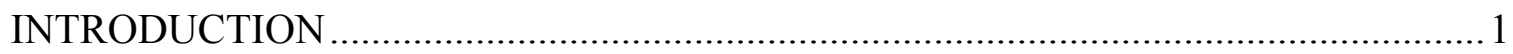

CHAPTER ONE: ETHOS, CONSPIRACY ARGUMENT, ANTI-CATHOLICISM, AND CHARLES CHINIQUY: A REVIEW OF THE LITERATURE ............................ 8

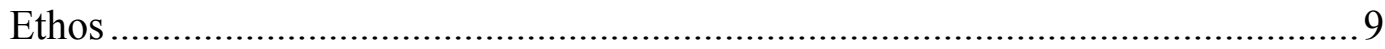

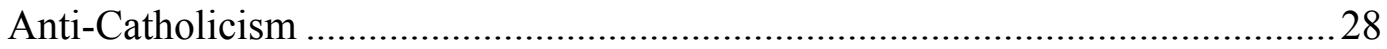

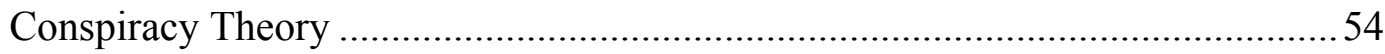

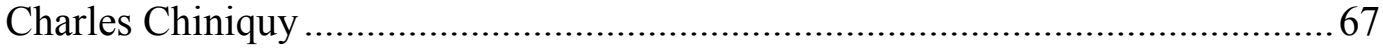

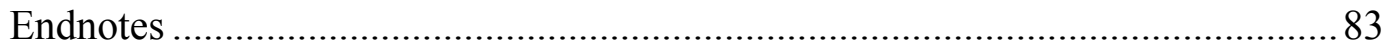

CHAPTER TWO: THE ETHOS OF A RENEGADE: CHINIQUY'S SELF

CONSTRUCTION IN FIFTY YEARS IN THE CHURCH OF ROME ...........................8 88

External Ethos Via Printed Paratext .............................................................. 94

Internal Ethos Via Autobiographical Constructs............................................. 108

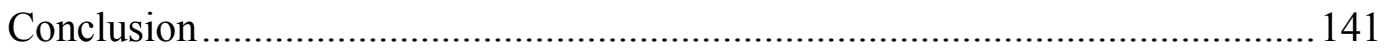

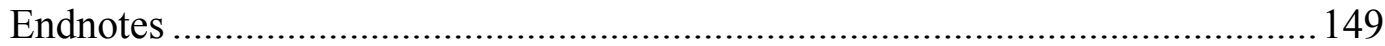


CHAPTER THREE: MAKING ANTI-CATHOLICISM CREDIBLE VIA THE

MEMORY OF A MURDERED PRESIDENT: THE ETHOS OF ASSOCIATION,

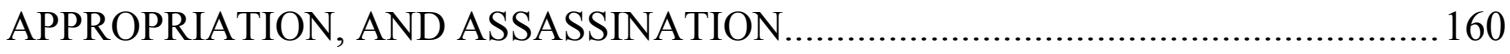

Chiniquy, Friend of Lincoln: Ethos by Association ......................................... 165

Lincoln, Enemy of Catholicism: Ethos by Appropriation............................... 176

The Catholic Church, Enemy of Lincoln: Ethos by Assassination ..................... 191

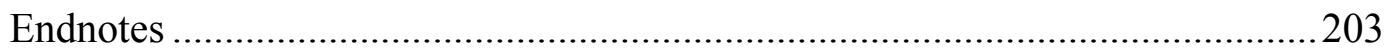

CHAPTER FOUR: FROM PAGE TO PICTURE TO PIXEL: THE CONTINUED LIFE

OF CHARLES CHINIQUY FROM THE NINETEENTH- THROUGH THE

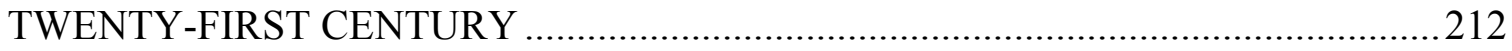

Nineteenth-Century Nativism and Chiniquy: The A.P.A. Magazine...................2214

Twentieth- and Twenty-First-Century Anti-Catholicism: Jack Chick’s Comic

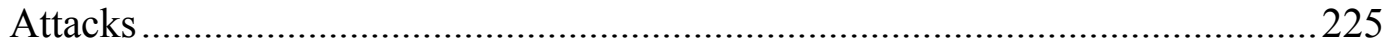

From Page to Picture to Pixel: A Nineteenth-Century Renegade and the Twenty-

First Century World Wide Web .............................................................2246

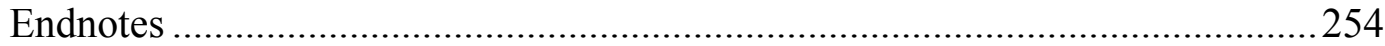

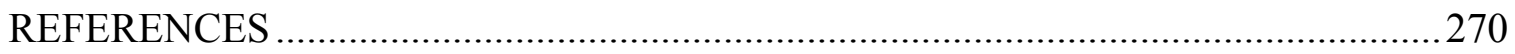

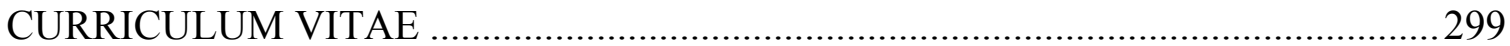




\section{INTRODUCTION}

"All men of prominence after death," noted the American historian Carl Russell Fish, "are liable to . . misrepresentation" (724). Writing in the American Historical Review (July 1924), he posited that when it came to distorting the deceased, "[a]t the present time . . . Lincoln is the chief victim." Fish challenged a claim then being made in the name of the slain chief executive that he found both "absurd" yet widespread: it had "recently circulated by the million [sic]" (724). The "current falsification" he condemned was that the great emancipator was a religious bigot. Fish quotes from "An American Protestant Protest against the Defilement of True Art by Roman Catholicism," which alleges Lincoln said, "Unfortunately, I feel more and more each day, that it is not against the Americans of the South alone I am fighting. It is more against the Pope of Rome, his perfidious Jesuits, and their blind and bloodthirsty slaves ... that we have to defend ourselves .... [sic] It is to Popery that we owe this terrible Civil War." Fish argued, correctly, that "the spirit of the quotation is contrary to the whole character of Lincoln's thought and expression, ... [and] that . . . it is no less absurd to attribute such a statement to Lincoln, than it is to accuse the papacy of such a position." He reasoned that this kind of "fabrication," of which "[m]any similar inventions" were "being continually circulated," was done "in order to attach [Lincoln's] great prestige to this cause or that" (725). 
In the years following the Civil War, Lincoln's name- - his "great prestige"was attached to many a cause and movement. In this dissertation, I examine how an anti-Catholic, conspiratorial Lincoln was constructed and used to promote an intolerant and xenophobic agenda beginning toward the end of America's so called Gilded Age (roughly 1880-1900) and continuing into the present day.

Arthur Goldwag (2012) writes of “America's long-standing penchant for conspiracy thinking” (14), which has, as Timothy Melley (2000) states, "animated our political culture from the early Republican period to the present, at times powerfully swaying popular opinion" (vii). Conspiracy theory has attracted the consideration of a number of scholars from a wide scope of disciplines; however, it has not received significant attention within the discipline of rhetoric and composition (for an exception, see Sharon Crowley's [2006] Toward a Civil Discourse). This lack of attention is especially striking in light of rhetoric and composition's longstanding interest in popular and political discourse, argumentation, and persuasion. My dissertation adds to the interdisciplinary body of scholarship concerning conspiracy theory by examining it as rhetoric, focusing on how the construction of a conspiracy proponent's ethos/character affects the persuasiveness of his or her conspiracy theory. I am arguing that ethos construction plays a much more significant role in conspiracy persuasion than typically considered.

In "The Paranoid Style in American Politics" (1964), Richard Hofstadter describes the importance played by "the figure of the renegade from the enemy cause"- the ex-Mormon, ex-Mason, ex-nun, or ex-Communist—in American conspiracy argument. This dissertation engages with Hofstadter's thesis by examining 
the ethos of one prominent "renegade"-Father Charles Chiniquy (1809-1899), an exCatholic priest whose conspiracy charges were extensively used by anti-Catholics and nativists during America's Gilded Age and well into the twentieth- and twenty-first centuries. Though no longer the political force it once was, anti-Catholicism has a long presence in American culture. The Pulitzer Prize-winning historian Arthur Schlesinger described anti-Catholicism as "the deepest bias in the history of the American people" (qtd. in Goldwag 199). I use as a case study Chiniquy's 1885 autobiography Fifty Years in the Church of Rome, in which Chiniquy claims that President Lincoln spoke at length with him about the Catholic Church's sympathies with and covert working for the Confederate cause - including its desire to assassinate Lincoln. With Lincoln as his star witness against the Catholic Church, Chiniquy's conspiracy narrative was widely circulated to promote a nativist and anti-Catholic agenda. Whether one believed in Chiniquy's tale about the dead president depended on whether one believed in Chiniquy the ex-priest; thus, my dissertation uses Chiniquy's ethos construction as a means of examining and understanding the role ethos plays in persuading people to accept extreme or, to borrow Hofstadter's problematic term, "paranoid," claims.

In Chapter One, I review the literature in four areas of scholarship that act as my dissertation's principal historical and theoretical approaches. I start with the literature concerning ethos, demonstrating the need for increased consideration to ethos in conspiracy theory in general and in the conspiratorial claims of purported "renegades." Second, I survey scholarship regarding American anti-Catholicism, a pervasive bias in American culture since the days of English colonization, and one that helped create an 
American identity of the nation as Protestant and not Catholic. My dissertation concentrates on Gilded Age anti-Catholics and their use of ex-clerics with alleged insider information that the Catholic Church was maneuvering against the United States. Though these ex-clerics and their confessional and conspiratorial disclosures were popular methods of furthering socially and politically prominent nativist and antiCatholic agendas, they have not received substantial consideration in the academy from rhetoricians. Third, I examine literature regarding conspiracy theory, arguing that conspiracy theory is a default argument in popular American discourse, thus meriting serious attention by rhetoricians. Fourth, I survey biographical, historical, and other scholarship regarding Father Charles Chiniquy.

In Chapter Two, I explore how ethos is constructed in the primary text for Chiniquy's Lincoln conspiracy theory, Fifty Years. The text constructs ethos in a multiplicity of ways, but I focus on five specific moves. I analyze Chiniquy's ethos formation in Fifty Years using a three-fold prism suggested by George Creps for understanding how conspiracy proponents typically locate themselves - as crusaders, experts, and victims. Chiniquy relates to his audience via each of these three roles, but the text also adopts two other significant postures not described by Creps. First, Fifty Years positions Chiniquy as a visionary, as somebody who hears the voice of God. By depicting a "mysterious" voice that helps his Catholic self see the faults of the Roman way, Chiniquy can call on the definitive witness for a Christian audience-God. Second, Fifty Years positions Chiniquy as an insider within the conspiratorial organization (the Catholic Church) — but an insider who always, on some level, knew that the institution was wrong: at heart, he was always a renegade. Consequently, he 
can exploit the authority of first-hand knowledge as a Catholic minister while separating himself from apprehensions held by anti-Catholic readers of believing and trusting someone who had been a part of (in their view) a profoundly foreign religion. Chiniquy may have been a Catholic, but the text presents him as having always been, at heart, a Protestant. The chapter ends by examining other ex-priest accounts as well as current, secular conspiracy theories for occasions of these types of ethos construction.

In Chapter Three, I analyze how the memory of Lincoln was used to provide credibility to the anti-Catholic movement. I examine how both a purported Catholic plot against the president and a president who claims a Catholic conspiracy against himand the Union - were constructed by Chiniquy in Fifty Years to support his antiCatholic message. I concentrate on three themes, all of which have implications concerning ethos in conspiracy narratives. First, Fifty Years constructs Chiniquy as an intimate friend of Lincoln, which performs as a potent means of ethos construction, particularly during the post-Civil War time period. This is ethos by association, in which an author or speaker gains believability for extreme claims by associating with another person considered as exceptionally trustworthy. Second, the text situates Lincoln as an adversary of Catholicism. Chiniquy places the case against the Catholic Church in the mouth of the sixteenth president, thus grounding his case on the ethos of Lincoln. This rhetorical move is ethos by appropriation: the anti-Catholic movement appropriates Lincoln, giving it and its conspiracy message greater credibility. Third, the text constructs the Catholic Church as the nemesis of Abraham Lincoln and the American republic. Ethos is not always positive: when constructed by one's adversaries, ethos becomes negative. This is ethos by character assassination. I examine political 
assassination as a conspiracy trope, demonstrating its helpfulness in constructing an opponent as treacherous to the body politic.

In Chapter Four, I explore the reception by anti-Catholics of Chiniquy's conspiracy theory, concentrating in particular on how his - and Lincoln's - ethos were used to make credible the anti-Catholic message. The late-nineteenth century saw other men publish exposés of their past lives as priests. More than one of them appeared on the nineteenth- and early twentieth-century anti-Catholic lecture circuit. Their narratives were retold in the anti-Catholic press, and their stories were spread. However, none have the presence in the twenty-first century that Chiniquy's has. His narrative remains available on Kindle, as a comic book, and throughout the Internet. What was there about him that leads to his book still being used today? There are various factors, but I contend that his long-lived popularity is due, in part, to an especially effective ethos construction concerning the memory of Abraham Lincoln and a sensational message that draws upon anxieties of a foreign other.

This dissertation adds to our understanding of how persuasion works, the act of which is a deeply complex process, involving a number a situtational and contextual factors; this complexity certainly characterizes conspiracy claims. In this perennially popular genre in American socio-political discourse, my project adds to our understanding of the working of conspiracy claims, arguing that ethos construction plays a much more substantial role than typically considered. As Hofstadter demonstrates, "the renegade from the enemy cause" has had a reoccurring role in persuading significant segments of the American population to accept what others 
would characterize as extreme, even "paranoid," claims. Chiniquy's Lincoln conspiracy theory is a means of testing Hofstadter's thesis, for the acceptance of Chiniquy's narrative about the murdered president ultimately hangs on belief in Chiniquy the expriest; this case and others like it rests or falls upon the basis of ethos. The use of Chiniquy's allegations by the historically important anti-Catholic and nativist movements thus proves an excellent case study for analyzing the role of ethos in how renegades used conspiracy discourse to support claims not easily established or repudiated, claims, which Aristotle argues, are where ethos proves most persuasive. Fifty Years is a rich text for rhetorical analysis, a close and theoretical reading of which provides valuable heuristics for examining other conspiracy claims. But I would add that an examination of the ethos constructions of this text extends our knowledge of ethos construction beyond the conspiracy genre. The ethos of association, appropriation, and assassination, for instance, are not limited to conspiracy narratives but have meaning and usefulness in other types of public, religious, and political rhetoric. Finally, as we approach the sesquicentennial of his death, my dissertation adds not only to our understanding of ethos construction in conspiracy argument but also to the ongoing rhetorical—and political—use of the memory of the great emancipator, Abraham Lincoln. 


\section{CHAPTER ONE}

\section{ETHOS, CONSPIRACY ARGUMENT, ANTI-CATHOLICISM, AND CHARLES CHINIQUY: A REVIEW OF THE LITERATURE}

In this chapter, I examine four areas of scholarship that serve as the primary historical and theoretical approaches for my dissertation. First, I begin by surveying literature concerning ethos; in so doing, I am suggesting the need for increased attention to ethos in conspiracy theory in general and in the conspiratorial claims of alleged "renegades" from marginalized communities (such as members of the nineteenthcentury Roman Catholic Church in the United States) who were viewed with anxiety and suspicion by the dominant culture. Second, I review scholarship concerning American anti-Catholicism, an endemic prejudice in American culture since the days of British colonization, and one that helped create an American identity of the country as Protestant and not Catholic. My dissertation, in particular, focuses on Gilded Age antiCatholics and their use of ex-clerics with putative insider knowledge that the Catholic Church was plotting against the United States. Although these ex-clerics and their confessional and conspiratorial exposes were popular means of advancing socially and politically prominent nativist and anti-Catholic agendas, they have not received significant attention in the academy in general or from rhetoricians in particular. Third, I review literature concerning conspiracy theory. My dissertation argues that conspiracy theory is a default argument in popular American discourse, thus deserving serious 
consideration by rhetoricians. Fourth, I survey the history of and scholarship concerning Father Charles Chiniquy, who serves as my dissertation's case study. Chiniquy, I would argue, deserves greater attention not only for his place in history but also rhetorically for his use of conspiracy theory. He provides an excellent site for analyzing the role of ethos in how renegades used conspiracy argument to support claims not easily established or refuted, which is where ethos, as Aristotle argues, proves most persuasive.

\section{ETHOS}

\section{Overview}

Able to address socio-political arguments, ethos remains a vital concern in modern rhetoric. ${ }^{1}$ In my dissertation, I add to this ongoing conversation by using ethos to understand the rhetoric of conspiracy argument and its intertwining relationship with renegade rhetoric. In so doing I am following in the work of Richard Hofstadter ("The Paranoid Style in American Politics" 1964), to whom I am indebted for the concept of renegade rhetoric, which concerns "the figure of the renegade from the enemy cause" (34); Earl George Creps III, who concludes his “The Conspiracy Argument as Rhetorical Genre Ethos" (1980) calling for further research concerning "the role of the speaker's ethos in defining the conspiracy genre" (199); and Thomas B. Farrell's 1993 analysis of Senator Joe McCarthy's anti-communist conspiracy charges, the ultimate success of which, Farrell argues, was determined by the senator's character or ethos (39-41). In the following section, I survey the literature concerning ethos by first examining the complexities involved in describing ethos, looking at a variety of ways it 
has been defined and understood historically and currently, giving special attention to its relationship with "character." I then consider three interrelated elements of ethos that have a special bearing on my dissertation: the pragmatic, idealistic, and public nature of ethos/character. I conclude by briefly describing the benefits of ethos in understanding and analyzing anti-Catholicism, conspiracy argument, and my case study, Charles Chiniquy.

\section{Defining Ethos}

Widely understood as the use of a speaker's character (in some sense) in speech or persuasion, ethos has a long established place in Western rhetoric: "[n]o other Aristotelian 'proof' has been subjected to more empirical examination" (Craig Smith 2). Though often connected to Aristotle as one of his three artistic proofs (along with logos and pathos) that ground a rhetor's appeal, neither the term nor the concepts involved in ethos were invented by Aristotle. ${ }^{2}$ Rather, in his Rhetoric, Aristotle provided an early systematic organization to rhetorical issues, practices, and theory, including the role of ethos in persuasion. Aristotle was not the only teacher of rhetoric in the classical world to connect ethos/character to persuasion. In Antidosis, Isocrates stresses having a good reputation in making a successful appeal: "the man who wishes to persuade people will not be negligent as to the matter of character" (page 339; paragraph 278). ${ }^{3}$ Here, though, it is important to note that Isocrates and Aristotle (at least in his Rhetoric) view the nature of ethos/character differently. When discussing ethos as part of the rhetorical art, Aristotle speaks of it as something created in the speech, while Isocrates speaks of it as something pre-existent to and separate from a speech: for Isocrates, the type or nature of "character" in which a person should "not be negligent" refers to a person's 
"honourable name" and "good repute." Or as James S. Baumlin (1994) states, "If Isocratean tradition asserts the speaker's need to be good, Aristotelian tradition asserts the sufficiency of seeming good" (xv). However, both Aristotle and Isocrates see ethos/character as essential in changing minds. For Isocrates, ethos is more persuasive than any stylistic word choice, rhetorical flourish, or sophistic argument: "the argument which is made by a man's life is of more weight than that which is furnished by words." And Aristotle called ethos perhaps "the most authoritative form of persuasion" (page $38 ; 1.2 .1356 a .4)$.

Although "at once relatively simple," ethos is also "exceedingly complex" (Jasinski 229), or as Farrell describes it, "one of the most enigmatic concepts in the entire [Aristotelian] lexicon" (80). There are various reasons for its complexity. Ethos has had a long life in the Western rhetorical canon, stretching back to classical Greece, and this longevity has led to ethos being attended to by a variety of scholars and practitioners, all speaking from different cultural locations and senses of identity. Race, class, gender, and culture all play a role in understanding or determining ethos/character. ${ }^{4}$ Ethos has not always had the same place or even stature in rhetorical theory and practice (Baumlin [2001] 268; Cherry 389; Johnson [1996] 244; May 3). Aristotle, for instance, categorized ethos under invention, one of three means of proof that a speaker could use to persuade. Aristotle's Rhetoric, however, though known and utilized to some extent by his rhetorical successors (Cicero, Quintillian), did not become a standard text in the period immediately following his death, nor was it readily accessible for centuries: "the treatise was not a major influence on the teaching of rhetoric until it was rediscovered and translated into Latin by George Trebizond in the 
fifteenth century and first printed early in the sixteenth century" (Kennedy 93). As such, while character remained a concern, rhetoricians did not limit themselves to an Aristotelian definition nor to his Greek term (Quintillian states that there is no exact equivalent in Latin for ethos [Institutes of Oratory 6.2.8]). James M. May grants "general similarities" between Cicero and Aristotle; however, he argues that Cicero's "analysis of ethos is not, in its details, particularly Aristotelian" (4), nor could it be in light of how Roman culture would have construed character $(6,9) .{ }^{5}$ James S. Baumlin (2001) points to a related complication: what counts for "character" relates to how a culture understands "selfhood" or what counts as "self." He argues that changing psychological models and notions of selfhood affect each culture's understanding of ethos/character, making ethos/character cultural, constructed, and changing. Additionally, feminist scholars (Jarratt \& Reynolds; Reynolds; Schmertz) have examined the relationship between ethos and subjectivity, challenging essentialist concepts of a stable self and positing potential benefits for those traditionally marginalized.

One final complication with ethos concerns the nuances of meaning available in both ancient and current usage. As Quinn Warnick (2010) points out, when modern-day advertisers, political talking heads, and business leaders "speak of the ethos of an advertisement, the ethos of a political party, or the ethos of an entire company," ethos can mean "anything from 'credibility' to 'personality' to 'character' to 'spirit' (23). Reynolds adds that today it "often refers to the character of an age, era, society, or culture, something like zeitgeist" (327). The diversity in contemporary definitions parallels that found in the ancient Greek term. Considering both its Aristotelian and pre- 
Aristotelian usage, scholars have used the involved etymology of ethos to understand the term in its classical context; but they also explore ancient etymology as a means of opening up ethos to postmodern rhetorical concerns (Chamberlain; Cherry; Frobish; Halloran; Kennedy; Reynolds; Warnick; Welch). Reynolds writes, "Standard translations of the Greek word ethos have not maintained its complexity" (327), and Schmertz posits the "rich tradition of conflicting interpretations of ethos" as "stemming in large part from confusion as to the word's etymology" (Schmertz 84).

Beginning with Homer and continuing through Hesiod, Herodotus, and Plato (among others), Charles Chamberlain (1984) traces the linguistic trail that leads to Aristotle's own usage. ${ }^{6}$ By Aristotle's time ethos “usually" meant human character (97); however, ethos originated among the animals: "the word originally designates "the places where animals are usually found.'” Homer, for instance, only uses the plural form of the word and never of humans but only of animals. Chamberlain elaborates on one instance in Homer, a simile in the Iliad, in which a stabled horse breaks free to return to "the "ethea and nomos of horses." Although distant from the meaning of ethos in Aristotle, this sense is not unrelated. Chamberlain argues that it contains the foundation for ethos's later meaning as character, for here the word has "the idea of 'belonging in'" (97) and the simile in which it is used points to a key concept in Aristotle's later discussion about character creation in his Nicomachean Ethics, "the power of habituation" (98). In the simile, a wild horse does not belong in a stable; that is not its habitat. Rather, it belongs in the place where wild horses are usually found, which is where it will run to, with joy, if given the chance in spite of human efforts to domesticate or habituate it to a stable. This emphasis on habituation is a key point in 
Aristotle's discussion about how ethos/character is developed in a person in his Nicomachean Ethics (102-103). ${ }^{7}$ Commenting on Chamberlain, Margaret D. Zulick (2004) grants, "One can perhaps see how the name has traveled from 'lair' to 'habit' (via 'habitat') to 'character' in the sense of the constellation of habits of thought, manners, and reputation that constitutes a rhetorical subject" (20). Chamberlain next considers the work of Hesiod and Theognis, in which ethos is used both more often than in Homer and in the singular; it is also used of people. Ethos is now an "arena in which people ... move," and in addition, it is an "essence" that "resists the imposition of outside influences" (99). Chamberlain raises the question of whether those in the ancient world thought it possible to change ethos - an important question not only for ethical concerns surrounding character building but also rhetorical concerns about constructing ethos in a text. He suggests that at least some people thought that ethos was "susceptible to change, but only through a process of long association best done in childhood" (100): even here, one sees a connection between habituation and ethos. Chamberlain points to further nuances of meaning in the development of the word including a "political" usage in which "ethos refers to the peculiarities which people of a certain polis acquire as a result of being brought up under its particular laws and customs" (101). These different "strands of meaning and implication" would have been available to Aristotle when he wrote about ethos.

This attention to origins, for instance, helps differentiate ethos as a rhetorical concept concerned with character as used in persuasion from a philosophical inquiry into moral behavior understood as the study of ethics. Ethos and ethics are related: "ethikos ... or 'theory of living,' comes from the same Greek root [as ethos], and from 
there we derive the modern English word ethics" (Warnick 24). However, while ethos and ethics are related, they cover distinctly different ground. Reynolds critiques scholars who have translated ethos as "ethical" when the "Greek roots" of ethos "are habit, custom, and character" (327). Of course, ethos raises moral questions; historically, the practice of rhetoric in general has always raised ethical questions concerning how it may be used to manipulate. For instance, a rhetor can take on or construct a false character or persona in order to persuade (see Roger D. Cherry [1998] for the overlap and distinction between ethos and persona). However, as Gerald A. Hauser (1986) helpfully maintains, there remains a need for ethos to be distinguished from ethics: "Questions of ethos focus on the perceptions of the speaker caused by his rhetoric. Questions of ethical appeals focus on the issues raised (or suppressed) and the quality of arguments addressed to them. We need a concept of ethical appeal, quite apart from ethos, as a guide for testing the moral quality of rhetorical arguments" (101).

Scholars such as Reynolds, Hyde, and Halloran all suggest ways to connect places/haunts to human character while opening up areas of inquiry for ethos. Exploring how the relationship between ethos and "location"_- "one's place or perceived place in the world" (325); "the position from which ... [a] person speaks or writes" (326)— Reynolds considers the "spatial and social emphases" of ethos, making an argument, in part, based on etymology: "Careful attention to the etymology of ethos-its connection to space, place, or location — helps to reestablish ethos as a social act and as a product of a community's character" (327). In so considering, Reynolds sees the opportunity for ethos 'to open up more spaces in which to study writers' subject positions or identity formations" (326) including those who traditionally have not been regarded by their 
culture as having strong ethos-such as women who have been marginalized in patriarchal societies. Michael J. Hyde posits that by attending to the earlier or "primordial" meaning of ethos, "the ethos of rhetoric" can be viewed as speaking of how "discourse is used to transform space and time into "dwelling places"” that "define the grounds, the abodes or habitats, where a person's ethics and moral character take form and develop" (xiii). And S. Michael Halloran (1982) sees in ethos, understood as "a habitual gathering place," the foundation for the eventual Aristotelian usage: "I suspect that it is upon this image of people gathering together in a public place, sharing experiences and ideas, that its meaning as character rests" $(60)$. Note here that character, which might be thought an innately or essentially individual, personal, private, or subjective quality is rather the result of enculturation: it stems from a public gathering or community of people "sharing experiences and ideas," and so one man or woman's ethos comes via socialization. Referencing Halloran, Reynolds posits that understanding ethos as being socially constructed "shifts its implications of responsibility from the individual to a negotiation or mediation between the rhetor and the community" $(328){ }^{8}$ As a rhetor attempts to connect with an audience by his or her character to align with the standards of a community, ethos provides a means to understand the values of a community. Thus, ethos's shared cultural construction can make it helpful for understanding what counts as character/ethos - and thus proves persuasive to an audience — in a community such as, for my dissertation's purposes, the anti-Catholic and nativist communities, or those populations that believe conspiracy theories.

The Pragmatic, Idealistic, and Social Nature of Ethos/Character 
Having established the continuing importance of ethos, understood as character, to rhetorical theory, I now consider the character of ethos by examining three interrelated elements that have special importance for my project: the pragmatic, idealistic, and social nature of ethos. The complex and intertwining relationship between these elements provides at least part of the persuasive appeal of renegade rhetoric such as Chiniquy's autobiographical conspiracy narrative. Chiniquy's message tapped into his audience's sense of what counted as character (social) by constructing an ethos on the page (pragmatic) that connected to the ethos of his past and present life and experience (idealistic).

When it comes to the relationship between character and ethos, rhetoricians have diverged into two broad camps: according to Nan Johnson, there is a "pragmatic" and an "idealistic" view of ethos ("Ethos" 244). The idealist view sees the character of ethos as an appeal based upon the pre-existing "virtue of the speaker" (243), such as the converted Chiniquy's reputation as a devout Protestant; the pragmatic view sees it as "a mode of persuasion that relies on the speaker creating a credible character for particular rhetorical occasions" (243), such as Chiniquy's construction of himself in Fifty Years as a Catholic priest who, in his heart, was substantially a Protestant. For the idealist, ethos is akin to one's reputation: it is something with which one enters the rhetorical ring. For the pragmatist, ethos, while not necessarily disconnected from a rhetor's reputation, is developed or constructed in the moment of the speech or the text: it is something created in the heat of the battle. Classical rhetorical figures such as Plato, Isocrates, Quintilian, and Augustine would be aligned more with the idealist perspective, while Cicero and Aristotle should be counted among the pragmatists (243-44). ${ }^{9}$ In Aristotle's 
rhetorical scheme, ethos was an "artistic" proof (as opposed to "inartistic" evidence that did not require the art of rhetoric). In one of the key statements in the Rhetoric, which I quote here in full, Aristotle describes the importance of ethos as constructed in a speech (the bracketed material is the translator's [Kennedy]):

[There is persuasion] through character whenever the speech is spoken in such a way as to make the speaker worthy of credence; for we believe fair-minded people to a greater extent and more quickly [than we do others], on all subjects in general and completely so in cases where there is not exact knowledge but room for doubt. And this should result from the speech, not from a previous opinion that the speaker is a certain kind of person; for it is not the case, as some handbook writers propose in their treatment of the art, that fair-mindedness [epieikeia] on the part of the speaker makes no contribution to persuasiveness; rather, character is almost, so to speak, the most authoritative form of persuasion. (pp. 38-39; 1.2.4)

Jasinski suggests that Aristotle argued for ethos being "in" the speech and not the speaker out of concern "with identifying an 'art' of rhetoric" (229). This would not rule out a concern for personal morality or good character - a concern held by those who worry that rhetoric is an amoral or immoral tool. As Johnson states, "it is not Aristotle's intention to imply that virtue in the speaker can be or should be contrived" (243-44). But Aristotle here limits ethos rhetorically to something within the speech or text. Kennedy posits that Aristotle's limitation of ethos "to the effect of character as conveyed by the words of the speaker" and not "the great role of the authority of a speaker as already perceived by an audience" originated in the situation facing those 
who spoke in the courts or before political gatherings. They were often largely unknown to their audiences, and thus what mattered "was not who they were but what they said" (22). Speechwriters or logographers could be contracted to prepare a speech for their clients to commit to memory and present. The key for the logographer was to capture in words the character of their clients in such a way as to help make their clients' case persuasive; in essence, the logographer was to disappear, not calling attention to himself, but drawing on or drawing out or drawing their clients' character (Rollins). Lysias (445-380 BCE), a contemporary of Plato (who was also his critic and who includes him in his Phaedrus), was renowned for this ability. Dionysius of Halicarnassus credits Lysias's fame to his "skill in constructing means of persuasion from character" (qtd. in James Baumlin [2001] 264). Although Aristotle is fairly clear (1.2.4) about ethos being constructed in discourse (perhaps drawing from the logographers [see Fredal 253]), his own usage in the Rhetoric, writes Schmertz, does not seem to have been done "with great consistency" $(85) .{ }^{10}$ Kennedy concurs that ethos/character in the Rhetoric can have more than one nuance of meaning, "such as an innate sense of justice"; however, he posits that the "predominant meaning ... is 'moral character" and that in 1.2.4 "the word refers to the trustworthy character of a speaker as artistically created in a speech" (148).

In contrast to Aristotle's pragmatic ethos, others in the classical age and since have advocated for a more idealistic approach. Quintilian, for instance, stated, "no one can be an orator who is not a good man" (19). ${ }^{11}$ As Christianity grew in power in the West, and rhetoric became a concern of the church in its teaching and preaching, the 
idealistic view of ethos dominated homiletic theory (Johnson [1996] 244). In Christian thought, the ultimate power is in the Word itself, and a minister (who during this period of time would have been male) must recognize his dependence on God. Without personal holiness and a sincere desire for the divine, the ministering orator cannot even properly apprehend the truth of Scripture. In order to be an effective teacher, the preacher must be a holy man; he must embody the virtues he wishes to inculcate in his congregation. And his holiness, more than any rhetorical eloquence, would persuade. Although a minister should strive for eloquence, one who lacked this skill could still preach an effective sermon: as Augustine states, "the life of the speaker has greater force to make him persuasive than the grandness of his eloquence" (482).$^{12}$ While it was possible for a bad man to deliver a good speech that would benefit the hearers, God, who knows the heart, would still judge him for his sins: "For the man who speaks wisely and eloquently, but lives evilly, instructs indeed many who are eager to learn though he is unprofitable to his own soul as it is written" (482-83). ${ }^{13}$ Johnson argues that Augustine's idealistic leanings dominated the church in the centuries following, when sermons were an important part of the Western world's rhetoric. Russel Hirst (1994) demonstrates the importance of prerequisite ethos in nineteenth-century preachers. Although differences existed over "the nature of the education" needed to produce "proper ministerial ethos," there was widespread agreement "that the preacher should embody the virtue and holiness he endeavored to cultivate in others" (293). Elmer Gantrys need not apply. This of course bears on the believability of ex-clerics like Chiniquy - the Catholic counter-response against him would focus on allegations of a lack of integrity and morality. If ex-priests did not have the requisite holiness, then 
they were not worthy of being believed. While idealistic ethos dominated in the church, the pragmatic view held sway elsewhere: "The overall emphasis of rhetorical treatises designed for the academy and for the general public since the Middle Ages has maintained the Aristotelian-Ciceronian approach" (Johnson 244). James L. Kinneavy and Susan C. Warshauer (1994; p. 171) as well as Rollins concur on the prominence of pragmatic ethos in the contemporary teaching of composition. Rollins suggests that Aristotle's ethos is the favored approach both for its "eminent teachability" (51) (as opposed to a more Isocreatean model which would involve "a lifelong course in moral development") and the socially constructed nature of its rhetor: there is "a decidedly modern ring" to this ethos, for it "suggests that the speaking subject is socially produced" (52).

When interpreting the persuasive role of ethos, it is difficult to limit ethos to a binary of either pragmatic or idealistic. Intratextual and extratextual elements both play a role in the construction and reception of a text. The way in which readers or listeners understand a rhetor's character is not always limited to what they hear or read in the discourse moment, especially when readers have prior knowledge of the character of the author, which will affect their reading of the text. Authors may be able to sway readers to a different understanding of their character via the text, but they also may confirm their prior reputation in the minds of their readers. Crediting Hauser for the distinction in terms (27), Warnick provides a helpful overview of the complicated relationship between "internal" and "external" elements in the construction of ethos (with "internal" largely corresponding with the idealistic or extratextual view and "external" corresponding with the pragmatic of intratextual view). "The link between a text's 
content and context," Warnick posits, "is now firmly entrenched in modern rhetorical criticism, and any discussion of a text's ethos will almost certainly contain references to external elements: the reputation of the author, the place of publication, the physical properties the printed work, etc." (21-22). "[E]xternal elements," he writes, "color our analysis of the text and influence our perception of the text's ethos" (30; see also Miller [2001] 269). Content takes place within a context that embraces and exceeds a particular text. Rather than attempting to limit ethos to one or the other, I will argue that the power of ethos in texts like Chiniquy's autobiographical polemic rests in the relationship between the pragmatic and idealistic, the intratextual and the extratextual, the internal and the external.

Regardless of how ethos is understood - whether idealistically, pragmatically, or some blending of the two - it is essential to understand its social and public nature. In the ancient Greek world, ethos was initially concerned for public performance; as Karen Burke LeFevre points out,"[i]n Aristotle's view, ethos cannot exist in isolation; by definition it requires possible or actual others" [qtd. in Reynolds 333].) Halloran, too, points to the public nature or performance of what might have seemed a private virtue (moral character), explaining that "ethos emphasizes the conventional rather than the idiosyncratic, the public rather than the private" (60). It is this mix of the public and private, group and individual that allows ethos to illuminate the inner dynamics and character of a culture, for as Halloran points out, "To have ethos is to manifest the virtues most valued by the culture to and for which one speaks." Kate Ronald argues that ethos "work[s] in the spaces between personal and public life" (37), defining it as 
"the appeal residing in the tension between the speaker's private and public self" (39). In so arguing, she calls into question hard and fast distinctions between personal and public: "in order to be an effective public speaker, one must cultivate a personal sense of ethos. This ethos in turn requires attention to the welfare of one's audience. Again, we're back to the notion that classical rhetoric demanded a dialectic between the personal and public discourse of the speaker" (44).

Rhetoric always concerns itself with an audience, and this is no less true with ethos. Ethos may call on the audience to consider the speaker's character outside the discourse event, questioning whether the rhetor's life/character provides credibility for the claims: did Chiniquy leave the priesthood for conscience sake or because he could not get along with his superiors? Or it may call on an audience to determine from the speech itself whether the speaker, who might be personally unknown to the audience, has credibility, questioning the text for signs of appropriate authority for the claims: does Chiniquy demonstrate a true knowledge of Catholic doctrine, thus demonstrating an expertise to be believed? But in both cases, the character of the speaker/writer is being considered by an audience. The ethos/character of rhetoric is not something to be enjoyed at home, alone, by the orator or author; rather, in some form or fashion, it is employed to achieve persuasive ends among an audience. Additionally, the ethos/character that an individual rhetor utilizes stems from and connects with the ethos/character of the audience. The speaker taps in to what the community values, making the rhetor's constructed ethos a product of the community's ethos, which is why one can study a community's values by studying how an individual understands those values. In other words, a rhetorical analysis of a successful rhetor (such as Chiniquy) 
demonstrates not only that individual's ethos but also the ethos of the community reached (such as the anti-Catholic movement). The ethos of an individual connects and reflects the ethos of a group.

Ethos cannot be reduced to being "one of several tools in the rhetoricians toolbox" (Schmertz 83), nor is it entirely in the control of an author/speaker-discourse speaks through him/her. "Locating ethos in written text," Reynolds argues, "requires attention to the mediation or negotiation that goes on in the spaces between writers and their locations" (333). Whether viewing ethos in the author, audience, medium, or message, it remains unstable, fluid: "ethos is not something 'embodied' by the classical orator with his audience, nor it is crafted in solitude by the modernist artist in his garret. ...Ethos, like postmodern subjectivity, shifts and changes over time, across texts, and around competing spaces" (Reynolds 326; see also Schmertz 85). It remains a construction, a process of "interpretation" (Hauser). But with its concern for the social—personal/public, group/individual—and character — pre-existing and textual, ideal and pragmatic — ethos offers a valuable means by which to understand individual and cultural identities and their role in persuasion.

\section{Conspiracy Argument, Charles Chiniquy, and Ethos}

Questions of ethos and character are at the heart of conspiracy arguments. When Hofstadter describes the "distinguishing" quality of "the paranoid style," he uses the language of evil incarnate: practitioners of the paranoid style view history itself as "a conspiracy, set in motion by demonic forces" (29). Indeed, the very word "conspiracy" denotes ethical malfeasance: a conspiracy is a "combination of persons for an evil or 
unlawful purpose; an agreement between two or more persons to do something criminal, illegal, or reprehensible (especially in relation to treason, sedition, or murder); a plot" (OED Online 2a). (This argument is taken up more fully in Section III below.) Those arguing for the existence of a conspiracy must persuade their audience that wrongdoing is afoot; and in order to successfully persuade an audience of the dark machinations of a cabalistic plot, those revealing the alleged plot must construct an effective ethos of their own while destroying the character of their opponents. For instance, in order to convince an audience that George W. Bush knowingly allowed the Twin Towers to be destroyed by suicide bombers in order to provide a pretext for war with Iraq, the 9/11 Truth movement must demonstrate to a skeptical crowd that Truthers are reliable, ethical, credible authors - they know the facts and how everything fits together. Further, they must attack the character of those they allege to be conspirators - they must paint "W" as the nation's greatest traitor, willing to murder thousands out of a desire to avenge his father's honor. The effective conspiracy argument necessitates careful construction of authorial ethos and pathos-filled character assassination. $^{14}$

Using the framework provided by ethos to consider conspiracy arguments in general and my case study in particular serves several significant purposes. First, it addresses a gap in rhetorical theory. Earl George Creps III concludes his "The Conspiracy Argument as Rhetorical Genre Ethos" (1980)—a work that David Zarefsky (1990) describes as "the most thorough rhetorical study of the genre of conspiracy arguments" (103) — calling for further research concerning "the role of the speaker's ethos in defining the conspiracy genre" (199); my dissertation's focus on ethos 
construction helps fill this need. Second, my focus on ethos construction elucidates the workings of a particularly important strain of conspiracy argument that, historically, has had great appeal to the American public - the rhetoric of "the figure of the renegade from the enemy cause" (Hofstadter 34). Hofstadter describes the historical importance of the renegade - the ex-Mormon, ex-Mason, ex-nun, or ex-Communist-in American conspiracy argument. Indeed, numerous renegades consisting of alleged and actual exnuns (Maria Monk, Edith O'Gorman, Rebecca Reed, Margaret Shepherd) and ex-priests (Charles Chiniquy, William Hogan, J. M. McNamara, George P. Rudolph, Joseph Slattery) formed a rhetorical frontline against the American Catholic Church. Rather than being an optional way of examining renegade rhetoric, ethos construction is essential to understanding its persuasiveness. Aristotle argued for the importance of ethos to persuasion in general but especially "in cases where there is not exact knowledge but room for doubt" ( $38 ; 1.2 .4)$. In alleging covert plots and conspiracy narratives, in which unquestionable proofs are difficult to provide thus leaving room for doubt, the persuasive appeal of a renegade largely rests on the rhetor's ethos/character: people believed an ex-priest's conspiracy charges because they believed in him, his personal story, his character, his narrative of defection from darkness to light. This dissertation engages with Hofstadter's thesis by examining the ethos of one prominent renegade - Charles Chiniquy. In so doing, it lays the groundwork for understanding the appeal of other renegades, historical and contemporary, and their conspiracy charges. Third, with its emphasis on collective, social, or public character, ethos lends itself as a means for understanding group identity: "To have ethos is to manifest the virtues most valued by the culture to and for which one speaks" (Halloran 60). Ethos reveals the 
values of the rhetor and those of his or her audience. In the case of a successful appeal, such as with Chiniquy's conspiracy narrative, which connected powerfully with a large number of Americans over a number of decades, ethos construction reveals what is valued as "character" by his audience: the ethos/character of a successful rhetor reveals the ethos/character of his culture. Chiniquy's ethos can help us then understand the ethos of the anti-Catholic and nativist movements.

In this dissertation, I rely primarily on the pragmatic view of ethos, concentrating on Chiniquy's ethos as constructed in the text; however, for my project as a whole, I think it is best to keep both pragmatic and idealist perspectives in sight, maintaining a tension between the two, for that tension exists in reading an autobiographical text like Fifty Years and attempting to understand a rhetor like Chiniquy. In order to persuade a potentially skeptical audience, Chiniquy had to craft an effective textual ethos, one that connected the words on his pages with his actual life experiences. He had to be who he said was - a persecuted ex-priest, guiltless of the charges made against him, and an intimate of the sixteenth president with insider knowledge on the world's greatest conspiracy. The power of a text like Chiniquy's rests in its crafting of a credible authorial presence and also in that presence accurately reflecting the person in 'real' life for Chiniquy bases his autobiographical argument, in large part, not on shared texts but on his lived experience. Reverend Lyman Beecher and nativist Samuel F. B. Morse could retell other people's tawdry tales of life in a convent or a monastery, but Chiniquy and Maria Monk could tell those tales as their own. They are "ex's" with conversion stories to tell, and conversion stories have an immense interest or appeal to an audience raised in the tradition of the Apostle Paul 
being knocked off his horse or sinful Saint Augustine being told to "take up and read." Theirs were their own personal narratives, and personal experience carries rhetorical weight. But if those experiences are called into question, as when Monk's own mother called her a liar, a once persuasive ethos falls apart. Anti-Catholic, conspiratorial autobiographies like Chiniquy's depend upon both the author's experience and his textual creation — both his artistic craft and his inartistic character. Finally, I would mention that Chiniquy's charges against Catholicism follow the well-worn path of antiCatholic arguments established since at least the Protestant Reformation, and even further back if one considers the contributions of anti-clericalism. Although his own experience may be unique, Chiniquy's arguments predate and surround him, rising from the longstanding anti-Catholic discourse community. Chiniquy does not just speak for himself: the arguments—and the ethos—of centuries speak through him.

\section{ANTI-CATHOLICISM}

\section{Overview}

My dissertation engages at length with what John Higham (1988) describes as "[b]y far the oldest — and in early America — the most powerful of the anti-foreign traditions" (5): anti-Catholicism. ${ }^{15}$ Spread out over continents and spanning centuries, anti-Catholicism is a complex continuum of negative responses to Catholic doctrine, practitioners, and hierarchy, rooted in the Reformation and anti-clericalism as well as social, political, economic, and gender issues. Neither "Catholic" nor "Protestant" can be reduced to simple binaries; and Catholicism, Protestantism, and anti-Catholicism, in all their variety, cannot be read as singular entities. ${ }^{16}$ American Protestants did 
frequently believe in and act (at times violently) upon negative stereotypes; however, there was no one response by American Protestants to Catholicism. ${ }^{17}$ Moreover, American Catholics negotiated differently the demands of living their "Roman" faith in a secular democracy, with varying levels of assent to official church doctrine. ${ }^{18}$ Additionally, while often marginalized and maltreated by the majority culture, American Catholics should not be merely as passive victims. The Church responded vigorously to opposition, especially as it grew in number and influence and became not only the immigrant church but also the assimilated church. Ecumenical tolerance was not a defining virtue for any side. ${ }^{19}$ The Catholic defense often brought about a strong counter-response. Protestant Americans worried about a future republic in which they would share power with Catholics - worries aggravated by a view of history in which a powerful Vatican persecuted any and all in opposition (Sweeting 32). The antiCatholicism of America's past, while to be denounced for its bigotry and resultant mistreatment of a minority, must not be understood in terms of a good versus bad dichotomy. America's religious history, with ties to an older, European history, is more complex than a saints-versus-sinners narrative.

As a result of its lengthy and complicated presence in the American experience, anti-Catholicism has generated a broad body of scholarship to address its impact on American history (Billington; Davis; Hofstadter; Schultz; Welter), literature (Fenton; Franchot; Griffin; Levine), politics (Kinzer; Roy; McGreevy; Nordstrom; Wallace), literacy (Mattingly), immigration (Bennett; Higham; Knobel; Schrag), and sense of identity (Billington; Colley; Fenton; Franchot; Gjerde; Griffin; Malcom; Marchant). My dissertation engages with this body of work and adds to it both by focusing on one of 
the most prominent argumentative genres used by the anti-Catholic movementconspiracy theory — and by focusing on the rhetoric of one of the most prominent antiCatholic voices of the nineteenth- through the twentieth- and even into the twenty-first centuries: Father Charles Chiniquy.

In this section, I survey the literature providing necessary background information for understanding anti-Catholicism in the American experience and Charles Chiniquy's role in it. First, I consider the place of anti-Catholicism in the initial creation of an American identity, concentrating on the history of anti-Catholicism from the colonial period through the early years of the republic. Although my project focuses on the latter part of nineteenth century, it is important to pay attention to America's beginning, for it demonstrates how deeply embedded in the American consciousness was anti-Catholicism and the identification of the nation as Protestant. This provides an important context for understanding the depth of feeling by concerned nineteenthcentury Protestants to a nation rapidly becoming home to the "Roman" religion-a faith long held suspect and constructed as an inherent enemy of democracy. Second, I consider anti-Catholicism in the nineteenth-century: my case study originates during this time period, hence the need for an understanding of the anti-Catholic movements of this century. I also give notice to the nativist movements of the nineteenth century. Nativism is often conflated with anti-Catholicism, although the two should be separated, with nativism broadly understood as a fear of the foreign and foreigners. Third, I consider three typical rhetorical moves by which nineteenth century antiCatholics constructed Catholic faith as "Roman" and not American. 
A significant portion of the American electorate base their political views and decisions, in part, on the narrative of a Christian America of the past that must be maintained in the present and for the future. This section helps with understanding one of the key components, historically, that helped construct this nationalistic and religious identity: anti-Catholicism. Throughout this literature survey I am arguing for increased attention to anti-Catholicism in American life, suggesting its importance in the development of an American identity whose default is Protestant and "native," not Catholic and Roman. ${ }^{20}$

In Order to Make a More Protestant Union: America's Anti-Catholic Origins

For those in the British colonies and then the American states, the fear of Catholics lingered in the developing American imagination, helping create a sense of the nation as Protestant and not Catholic - it was a Protestant-normative culture. ${ }^{21}$ Fears of a Catholic "other" came natural to seventeenth century British subjects on both sides of the Atlantic who, according to Philip Jenkins (2003), "shared an elaborate mythology about Catholic misdeeds that almost amounted to a national foundation myth" (25). Linda Colley (2005) concurs, describing how British nationalism developed, in part, because of conflict with Catholic countries. "[W]ar with France brought Britons," Colley writes, "whether they hailed from Wales or Scotland or England, into confrontation with an obviously hostile Other and encouraged them to define themselves collectively against it" (5). Anti-Catholicism served an "integrative function" for the United Kingdom (Drury 102; see also Bennett [1988] 17; Higham 5; Tumbleson 17-19). Additionally, as demonstrated by Brandi H. Marchant (2012), 
throughout the seventeenth century England experienced turmoil related to the Protestant/Catholic divide, with the Gunpowder Plot of 1605 being one example (1415). Hence, the English fear of a foreign Catholic was not limited to Catholic powers from another shore, but also included attempts to subvert England (and her colonies) from within. Reflecting an English homeland that came to picture itself as a bulwark of Protestantism against a foreign, continental Catholicism (Tumbleson 1-2), those who colonized the Atlantic seaboard for the British crown did so, in part, to claim the land for Protestantism. Potential immigrants to Virginia, for instance, were told to transport "no traitors, nor Papists that depend on the Great Whore" (Waldman 4). It should be noted, however, that the colonists were not claiming a land for a unified Protestant church. New England Puritans condemned Virginian Anglicans, believing them to have retained vestiges of Catholicism: by this understanding, one could be Protestant and yet still Papist. Surrounded by Catholic New Spain and Catholic New France, colonists saw their Edenic attempt to return to the Protestant purity of a city set on a hill as one in constant peril from the Catholic menace, whether it be a French Canadian, a Spanish Floridian, or a Native American being used surreptitiously by Roman Jesuit: "Americans now felt the same Catholic threat against their national existence that the English had felt in the days of Elizabeth" (Billington 9). This fear of the alien Catholic subverting both king and God permeated the discourse of colonial America, for Thomas More Brown writes, "no intellectual tradition was more prominent, or more omnipresent," being "as vigorous in 1760 as it was in 1607" ("The Image of the Beast," 1). This rampant fear of the Catholic existed even though many colonists would never actually see a Catholic. Numbering around 25,000, Catholics constituted roughly 1\% of 
the 1770s population, with nearly all located in two states (Maryland and Pennsylvania); “[i]n New England John Adams claimed a Roman Catholic was as rare as a comet or an earthquake" (Marty 140-41).

Colonial fears of neighboring Catholics—and the King's policies toward them— played a role in the move from colony to nation: the thirteen colonies became the thirteen states, in part, because of anti-Catholicism. It did so not only by defining America as Protestant but also by defining the British crown's Protestantism as suspect. When they were fighting the French Catholics during the French and Indian War (17541763), the British crown passed muster in the eyes of the colonists as appropriately antiCatholic. However, in winning the wars and conquering Canada, misgivings arose about the sincerity of the British government's anti-Catholic convictions (Waldman 49). Specifically, the British parliament's enactment of the Quebec Act (1773) led the American colonists to imagine that their King was in bed with the Great Whore to destroy American freedom and faith. The Quebec Act was an effort by the Anglican British to deal with a conquered Catholic population, allowing them to retain their faith rather than forcibly converting them to the Anglican fold (Wills 180). But colonists were horrified that a fellow British colony was allowed to maintain an allegiance to the pope. Representing the fears of many, Alexander Hamilton asked, "Does not your blood run cold to think that an English Parliament should pass an Act for the establishment of arbitrary power and Popery in such an extensive country?" (qtd. in Waldman 50). The first Continental Congress (1774) accused King George's government of “erecting a tyranny" in Canada, "to the great danger, from so total a dissimilarity of religions, law, and government to the neighboring British colonies" (qtd. in Wills 180). The Congress 
protested in terms that reflect their worries of a Catholic presence so near the borders of their own land that they identified clearly as Protestant: the King had "established an absolute government and the Roman Catholic religion throughout these vast regions that border on the westerly and northerly boundaries of the free Protestant English settlements" (qtd. in Wills 180-81). The British compromise with Canada would not be easily forgotten or forgiven. When it came time in the Declaration of Independence to demonstrate the King's "history of repeated injuries and usurpations, all having in direct object the establishment of an absolute Tyranny over these States," America's founding fathers condemned the Crown "[f]or abolishing the free System of English Laws in a neighbouring Province, establishing therein an Arbitrary government, and enlarging its Boundaries so as to render it at once an example and fit instrument for introducing the same absolute rule into these Colonies.” A New Hampshire minister would later recall the colonial mindset concerning the Quebec Act: "We were all ready to swear, that this time [King] George ... was secretly a Papist; and whose design it was to oblige this country to submit itself to the unconstitutional powers of the English monarch" (qtd. in Billington, 17-18). He added that in New England the "real fears of Popery ... stimulated many timorous pious people to send their sons to join the military ranks." War, however, makes for strange bedfellows. If anti-Catholicism played a role in separating the colonies from a suspect Protestant crown, both the (unsuccessful) mission to entice Protestant and Catholic Canadians into joining the battle for independence and the actual entering into an alliance with an eminent Catholic power-Francedampened anti-Catholicism during the course of the Revolution (Billington 18-20; Dolan 73; Higham 6). 
Although Catholic France's help to the rebellious colonies dampened rampant anti-Catholicism, it did not disappear. Nor did the understanding that the colonies and then the states comprised a Protestant space. Even during the time of the Franco/American alliance, colonies continued to legislate against Catholics, with over half the states at war's end still stipulating officeholders must be Protestant (Billington 21). Following the war, gradually, many anti-Catholic pieces of legislation were abolished (Billington 22-23), and the American Catholic Church, according to one of its earliest historians, John Gilmary Shea (1890), “prospered” (419). ${ }^{22}$ However, antiCatholicism, though muted, remained with the United States during the early decades of its republic and into the nineteenth century. And equally importantly, Protestantism remained the default faith, as Jon Gjerde (2012) states, "Protestant Christianity was . . . central to American mythmaking" with "Catholicism provid[ing] a foil for the Protestant ideal" (34).

\section{The Nativistic and Anti-Catholic Nineteenth-Century}

During the nineteenth-century, anti-Catholicism would wax and wane as a focus of public fear-the rise in immigration by Catholics, the expansion of the American west, clashes over public schools, and economic crises would all affect its cultural momentum. And yet throughout the nineteenth century, anti-Catholicism remained endemic in American culture, with significant outbreaks of virulent, vocal, and at times violent anti-Catholicism.

Anti-Catholic feeling had subsided during the revolution and early Republic years; according to Billington, "there was every indication in the period before 1820 
that the No-Popery sentiment of colonial days had completely vanished" (24). But these were also the days before the Irish diaspora, when the Catholic population was a small percentage of the national population. It is estimated that in 1800 the United States had only 50,000 Catholics (Marty 272). However, by 1850 the Catholic Church had become the nation's largest denomination, and by 1900 Catholics numbered around $12,000,000$ - an increase in one hundred years from roughly $1 \%$ to $16 \%$ of the nation's population. The rapid influx of a people whose faith had long been constructed as alien and inimical to both biblical Christianity and American democracy would challenge Protestant Americans in ways that their Puritan ancestors had not experienced. At times, unfortunately, the nineteenth-century response was not in keeping with the ideals of the Constitution, but more in line with the worst of Reformation polemics.

Violence was not the typical response by either Protestants or Catholics to each other. However, there were incidents that would burn into the American imagination, especially during the antebellum period, with perhaps the most memorable being also one of the earliest— the destruction of the Charlestown convent (August 11-12, 1834). The Charlestown convent was a private school for girls run by Ursuline sisters; of their 47 students, the majority were “the daughters of Boston's Protestant, largely Unitarian, elite" (Franchot 138). Located near Boston, Henry James’s "little Puritan metropolis" (The Europeans 11), within sight of the Revolutionary War's Bunker Hill battleground, this elite school run by Catholic women became the site of cultural anxieties (Schultz 102-104). Several factors contributed to the eventual burning of the convent, including putative "escapes" as well as tales and rumors spread of secret abuses by the nuns (see Rebecca Reed's Six Months in a Convent [1835]). The famous patriarch of the Beecher 
family, Lyman Beecher, also played a precipitating role when he preached three antiCatholic messages "to huge congregations in three different Boston churches" on Sunday, August 10 (Franchot 138). On the following Monday night, a Protestant working or lower class mob attacked and burned down the convent, which was never repaired. According to Franchot, the attack was possibly the "most important political event in Massachusetts prior to the agitation surrounding the passage of the 1850 Fugitive Slave Law," marking "the renewal of anti-Catholicism" (136; see also Billington; Griffin; Schultz).

Following on the heels of the convent burning was the publication of what has become a seminal anti-Catholic text: Maria Monk's (1836) Awful Disclosures of the Hotel Dieu Nunnery of Montreal..$^{23}$ Although not the first "ex-nun" account-Rebecca Reed's Six Months in a Convent, for instance, had been published to great success the prior year (1835) - Awful Disclosures would capture the antebellum American readership, with estimates of 300,000 sold in the years prior to the Civil War, to be outpublished only by Harriet Beecher Stowe's (1852) Uncle Tom's Cabin" (Franchot 154). Monk, an alleged ex-nun (her mother denied it [Billington 101; Franchot 160]) and also alleged author (some have argued that Protestant ministers were the actual writers [Billington 101; Franchot 154]), charged that priests turned her Montreal convent into a house of ill repute, with the holy fathers regularly raping the sisters and then murdering (but only after first baptizing) any daughters or sons born to these unholy sessions. Monk's hugely successful narrative was widely accepted as true by the Protestant press (Billington 102). (And it possibly almost garnered her a marriage proposal from nativist, anti-Catholic, and pro-slavery inventor of the telegraph Samuel F. B. Morse. In 
a letter, James Fennimore Cooper, Morse's friend, worries that "Morse is about to marry a certain Miss Monk" [qtd. in Veil of Fear, ed. Schulz, xxxi]). Monk's case was built, in part, on the brick and mortar of the Hotel Dieu. She claimed an insider's knowledge of the secret passageways between a seminary and the convent, of places within the cloister where nuns were raped, babies were killed, and the innocent buried in pits with lime. Monk's believability thus rested on the actual edifice of the abbey and whether it conformed to her gothic description. (This argument via architecture repeats itself in other anti-Catholic works, including later authors who would literally sketch out the closeness of Catholic buildings or Catholic colleges [Georgetown] to prominent government offices in Washington D.C.) When William L. Stone, a Protestant lawyer and certainly not pro-Catholic (Billington 155), investigated the Hotel Dieu in 1836, he discovered that Monk's description of the abbey did not match the building's reality. For his troubles, Stone, who had been inclined to believe Monk's charges until the abbey's actual architecture disproved them, was rewarded with a Protestant literature that attacked him as either on the Jesuit payroll or "Stone-blind" (Billington 106). Although relatively quickly discredited, Awful Disclosures was republished throughout the nineteenth and twentieth centuries and remains available in print and as a Kindle ebook. Monk's book demonstrates the power of renegade rhetoric in the anti-Catholic movement.

As would be true throughout the nineteenth century (and well into the twentieth century), antebellum anti-Catholicism was often fueled by nativism (Billington; Bennett; Higham; Kinzer). American nativism was a complex movement, incorporating the Know Nothings of the 1850s, the American Protective Association of the 1890s, and 
the Ku Klux Klan of the 1920s, whose target varied according to the ethnicity, economic status, and religion of the teeming masses disembarking at Ellis Island or, with Asian immigrants in San Francisco. Nativist reactions to American immigrantsand their descendants - were the results of a variety of causes, including racial and religious bigotry, economic downturns, and fear of foreign influence. But while there was variety among nativists, there was also similarity: "What tied these movements to one tradition was the common vision of alien intruders in the promised land--people who could not be assimilated in the national community because of their religion or ethnicity" (Bennett [1988] 2). Nativism concerned itself with the identity of the native and with any perceived attacks on "true" natives by those who were not (Bennett 2; Higham 4; Schrag 233). Higham's definition is helpful: "Nativism is an intense opposition to an internal minority on the ground of its foreign (i.e., 'un-American') connections" (4). Nativism was a movement that worried about national identity, a perhaps natural anxiety in light of the nature of America's self-government and population, which with the exception of Native Americans, was and is made up of immigrants and their descendants. If government is "by the people" then it is essential to determine who exactly those people are.

Without eliding or diminishing its often bigoted and xenophobic nature, a simplistic description of this powerful series of political movements ignores the historical context that engendered it: "Many nativists seriously grappled with the question of what it meant to be an American, and their fears were not merely the product of arrogance, ignorance, and hatred" (Bennett [2010] 522; see also Higham 3; Schrag 30). While as Bennett points out "immigrants of the mid-nineteenth century 
appear as innocent victims from the perspective of later generations," to those already living in the United States at that time, the newcomers brought with them more than hopes and dreams of a better life for them and their families. Large-scale immigration put great financial and social stress on America's burgeoning cities, with immigrants being blamed for increases in crime, poverty, and epidemic diseases (Bennett [1988] 89). Social and economic anxieties, tinged with a conspiratorial tone and imbricated with worries over foreign powers attacking the nation via populating the new world with the denizens of the old, can be heard in Lyman Beecher's (1835) antebellum A Plea for the West: "If the potentates of Europe have no designs upon our liberties, what means the paying of the passage and the emptying out upon our shores of such floods of pauper emigrants - the contents of the poor house and the sweepings of the streetsmultiplying tumults and violence, filling our prisons, and crowding our poor houses, and quadrupling our taxation, and sending annually accumulating thousands to the polls to lay their inexperienced hand upon the helm of our power?" (54). ${ }^{24}$ Nativism reveals the socio-economic complexities and cultural tensions of a country, made up of immigrants, that defines itself with conflicting mythologies: America as an inclusive beacon for the teeming masses yearning to be free versus America as an excluding new promised land, a nation to be kept pure from foreign vices, viceroys, and vicars.

In the American context, nativism is not inherently anti-Catholic or a synonym for anti-Catholicism, though the two terms are often used interchangeably. One can be a nativist, as many Protestant and Catholic Americans were, toward non-Catholics such as Jewish or non-Christian Chinese immigrants; and one could be a German or Irish Protestant immigrant who opposed Catholic immigration. The religion of the newcomer 
was not the only cause for concern by American "natives." Higham describes three strands in nativistic opposition: "European radicals, European religion, and European races" (53). However, of these themes, Higham argues that anti-Catholicism is "the oldest — and in early America — the most powerful of the anti-foreign traditions" (5). But while anti-Catholicism and nativism should not be equated, when immigration becomes viewed as predominately Catholic, then the line between them blurs. Largescale Catholic immigration was not a concern during the colonial and early republic years, when the Church was a tiny minority that could be ignored, but this changes with the antebellum Irish diaspora (along with immigration from other Catholic nations). Billington argues that the unprecedented level of immigration should be viewed as "the most important causal factor leading" to the rise of antebellum anti-Catholicism (33). Historically, the first of three large-scale anti-Catholic and nativist political movements was the antebellum Know-Nothings of the 1850s (the other two movements were the latter-nineteenth-century American Protective Association [A.P.A.], and the Ku Klux Klan [KKK] of the early twentieth century). The Know-Nothing movementso named for the secretive nature of the organization, in which members, when asked if they belonged, responded that they knew nothing about it—incorporated a variety of organizations including "the American Party, the American Republican Party, the fraternal Order of the Star Spangled Banner, the Order of United Americans, the American Patriot Party, and ... various other orders, clubs, groups, and publications" (Schrag 29). Though short-lived (as was also true of the A.P.A. and KKK), the KnowNothing movement had the greatest political success. In the 1850s, Know-Nothings elected governors (California, Delaware, Massachusetts), state legislators, mayors 
(Boston, Chicago, Philadelphia), and over forty congressmen (Schrag 33). In 1856 the American Party's presidential candidate, former president Millard Filmore, finished third, behind the Republicans, but managed to garner $23 \%$ of the popular vote, capturing the electoral votes of Maryland (33). In the mid-1850s, the nation for a time seemed to displace its struggle over African slavery by focusing on so-called Roman slavery (Franchot; Griffin). But while the concerns of the Know-Nothing party might have elevated it to the level of a national party that could possibly win the White House, the nation's fervor was quickly displaced in its march to civil war.

The war and immediate post-war years saw a great diminishing of antiCatholicism from its Know-Nothing heights in the 1850s. A nationwide war had changed the nation, and its rebuilding affected its view of those once thought alien (Bennet [1988] 159). The war that divided also brought people together. Roughly a quarter of the two million men who served in the Union Army were not born in the United States, including almost forty regiments who called themselves Irish (Schrag 41). Schrag argues, "by virtue of their war service, Irish (and other) immigrants would thereafter regard themselves as complete Americans" (43). Better economic conditions, along with America's faith in its ability to assimilate, as well as a perceived need for new workers via immigration all contributed to a tolerance after the war (Higham 1920). Indeed, in the years immediately following the Civil War, as the nation rebuilt, immigration from once feared Catholic nations was actually encouraged, with states vying to fill and till their land with those from foreign shores (Schrag 7; see also Higham). However, while diminished, anti-Catholicism remained (Higham 28; Schrag $43)$. 
Anti-Catholicism in the Gilded Age focused on several concerns including public and parochial schools, government support of religious charities, Catholic political and government influence (Kinzer 4). These were fueled by significant social, political, and economic changes in the United States, including industrialization and urbanization (with a concurrent move away from an agrarian economy), and the return of mass immigration (Schrag 4). Billington argues that as the century moved toward its end, there was a "complex of disorienting developments that made this time reminiscent of the anxious years of the late 1840s and early 1850s" (166). Higham describes the economic challenges facing Americans during the last part of the nineteenth century (roughly 1885-1897) as "one of recurring calamities and almost unrelieved discontent, culminating in the savage depression of 1893-1897" (68; see also Bennett 165). In 1885 — the same year that Chiniquy published his memoir-Reverend Josiah Strong published Our Country: Its Possible Future and Its Present Crisis. ${ }^{25}$ Strong, one of the creators of the Social Gospel movement, uses half of his fourteen chapters to detail seven "perils" facing the United States: immigration, Mormonism, intemperance, socialism, wealth, the city, and Romanism. Quoting Catholic (or alleged Catholic) sources, Strong makes typical anti-Catholic arguments, positing that the principles of the Catholic Church are contrary to those upon which the nation is founded. Hence, the Catholic Church is opposed to "liberty of conscience" (47), "free speech and a free press" (48), and "free schools" (49); as such, "our fundamental ideals of society . . . are as radically opposed to Vaticanism as Imperialism. And it is as inconsistent with our liberties for American citizens to yield allegiance to the Pope as to the Czar" (54). The book was a publishing hit; by 1891 it had "sold 167,000 copies" (Kinzer 18). 
Commenting on the book's success, which he in part credits to Strong's "urgent, graphic, and vigorous style," Donald L. Kinzer (1964) argues that the more substantive reason for its popularity was that Strong had "struck nearly every current chord that could be sounded." And though Strong himself was not intimately connected with openly nativist groups, according to Dale T. Knobel (1996), Our Country encouraged nativist sentiment and activity to similar levels as that following Beecher's Plea for the West, published fifty years earlier $(196,195)$.

Despite having been discredited, Maria Monk's Awful Disclosures remained in circulation in post-bellum America. Monk's longevity demonstrates a favorite means of spreading the anti-Catholic message—-literature written by and lectures delivered by renegade Catholic clerics, alleged or actual former nuns and priests who revealed the dark, inner workings of a church hell-bent on destroying American freedom, families, and democracy. A. P. Stauffer (1933) describes this anti-Catholic lecture circuit as being comprised of "unemployed ministers, unfrocked priests, and charlatans" who "gain[ed] a lucrative living by giving lectures on alleged papal conspiracies" (19). The lecturers were not limited to former priests and nuns, who might, as in the case of Mr. and Mrs. Slattery, become husband and wife (Kinzer 110). Justin D. Fulton, a Baptist minister from Boston, was a prominent polemicist against Catholicism. ${ }^{26}$ While numerous born-and-bred Protestant ministers attacked the Catholic Church, often using the autobiographical work of ex-Catholics (as was true of Fulton who utilized Chiniquy's work), the "most effective" of the anti-Catholic polemicists, according to Stauffer, were the ex-priests and ex-nuns, "since they were popularly believed to 
possess intimate knowledge of priestly practices" (19). And of these renegade clerics, Stauffer argues, Chiniquy "was by far the most successful" (20).

The 1890s would see the rise—and fall—of the nativistic American Protective Association (A.P.A.). Started in a small Iowa town in 1887 (Kinzer 35), the A.P.A. would become the leading nativistic organization of the last decade of the nineteenth century (Bennett 171; Higham 62-63, 80-87; Kinzer; Knobel 212; Massa 29; Stauffer 156b). It was not the only nativistic group of the time. The United Order of Deputies, formed the previous year (1886) in Chicago had initially, according to Alvin P. Stauffer, seemed set to "dominate the new Know-Nothingism" (156b). However, it would be the A.P.A. that would be the most prominent nativistic voice in the decade before the dawn of the twentieth century. The A.P.A. never achieved Know-Nothings' level of electoral success, and never generated a national third party ticket. But the A.P.A. did help elect officials sympathetic to their causes. "In the spring of 1893," for instance, "the A.P.A. showed substantial strength in midwestern municipal and school board elections, and that fall contributed to William McKinley's phenomenally successful re-election as Ohio governor" (Higham 83-84). The electoral accomplishments of the A.P.A. were not entirely to the organization's benefit; if it attracted anti-Catholic voters to the Republicans, it also strengthened the appeal of the Democrats among Catholics and immigrants (Knobel 215). Due to a variety of factors, including the increasing cultural acceptance of Catholics and strife within the party, the A.P.A. disappeared relatively quickly from national prominence (Higham 86-87; Knobel 215-18). Knobel argues, however, that the A.P.A. did see success, with several of its concerns producing legislation across the country; although, he does not argue the A.P.A. actually caused 
this success (216). The A.P.A. does demonstrate the continued appeal of traditional anti-Catholic rhetoric through the end of America's long, nativistic nineteenth century.

\section{Understanding/Constructing American Identity via Anti-Catholic Arguments}

In the context of the history of the United States, the attempt to identify who is - and who is not - an American is fraught with complexity. Can there be a singular identity in a country defined by widespread diversity — from the many, one? And yet, in order to make the many one - to take a them and create a "we the people"- the citizenry of the United States have frequently defined themselves as "not them." In understanding what it means to be an American, the nation has described what an American is not in order to understand what an American is. Beginning in colonial times, the question of identity has been answered negatively: real Americans are not, for example, American Indians, African slaves, or Chinese immigrants. Following this tradition, nativists and anti-Catholics constructed Catholics as a foreign other, and in so doing constructed America as Protestant: "in writing anti-Catholicism, nineteenthcentury authors were writing — often desperately_-'Protestant,' 'America,' and 'Britain"' (Griffin 11). The essential foreignness of Catholicism in anti-Catholic discourse can be readily seen in the emphasis placed on the Roman nature of the Catholic faith and people. In Roads to Rome: The Antebellum Protestant Encounter with Catholicism, Franchot discusses her use of terms that "an irritated Bishop England once enumerated as 'nicknames' for Rome, ... includ[ing] 'Romish' (or 'Romanish'), . . . and, most important for my uses, 'Romanism'” (xix). Franchot justifies her use of this problematic language as being done "in the service of analyzing the specifically 
Protestant American cultural imperatives behind them." Language describing the Church in Roman terms pervaded the Protestant response to and understanding of American Catholicism. In Rome or America, Which? (1895), Baptist minister John T. Christian stresses the foreign nature of Catholicism not only in the binary title of the book as whole—Rome or America—but in each chapter's title. ${ }^{27}$ With the exception of chapter one, each chapter places the Catholic faith in Rome: "Rome and Morals," "Rome and Civil Liberty," "Rome and the Bible" (table of contents, page 6). Reverend Christian is not alone in Romanizing the faith; he is following in a long tradition. Beecher, for instance, writes of "the past unscriptural and anti-republican claims, maxims, and deeds of the church of Rome" (151). Josiah Strong cautions of the perils of "Romanism": "Our brief examination of the underlying principles of Romanism almost renders superfluous any consideration of its attitude toward our free institutions. If alive, it must necessarily be aggressive; and it is alive" (54). Catholics, themselves, were Romanists (Edward Beecher 121; Strong 210), whose priests served as Rome's ambassadors (Chiniquy 13, 567, 810). In so constructing Catholicism as Roman, antiCatholics and nativists othered the faith of their fellow Americans as Old World, European, and above all, foreign.

In a variety of ways, anti-Catholic and nativist speakers and writers portrayed this essential foreign nature of Catholicism (and in so doing, revealed their own construction of America and Americans). Billington writes of three central aims in antebellum anti-Catholic literature: "first, to show that Catholicism was not Christianity but an idolatrous religion ...; second, that Popery was by nature irreconcilable with the democratic institutions of the United States and was determined to insure its own 
existence by driving them out; third, that the acceptance of the moral standards of the Catholic church would be suicidal to the best interests of both Protestantism and the nation" (351). Les Wallace describes seven basic arguments used by the postbellum A.P.A. (emphasis throughout is from Wallace): first, "Roman Catholics owe ultimate allegiance to the Pope over and above any obedience ... required of a State or Republic" (120-21); second, "Allegiance to the pope requires Catholics to gain control of the government" (123); third, "American free public schools are prime targets for Catholic subversion" (129); fourth, "Catholics are an armed military, ready at the Popes request to rise up and seize political power" (135); fifth, "restrictive immigration is necessary to combat the Catholic menace" (139); sixth, "the Roman Catholic Church is despicable, wicked, squalid, and deserving of contempt" (142); seventh, "dedication to the United States and Protestantism requires an active defense against Romanism" (147). Elaborating on Billington and Wallace, ${ }^{28}$ I would suggest three categories of argument by which anti-Catholics constructed an un-American, at times anti-American, distinctly alien, Catholicism.

First, the Catholic Church was foreign to American democracy and its republican institutions. Anti-Catholics argued that the essential nature of the American experience was at variance with the Roman Catholic Church, seeing it not only or primarily as a religion but more as a despotic political system seeking international temporal power including reigning over the United States: "it has always been, and still is, a political religion" (Lyman Beecher 140). In this view, the Catholic Church was opposed to those rights enshrined in American culture, especially freedom of speech and freedom of religion; Strong quotes an 1864 papal letter condemning "[t]hose who 
assert liberty of conscience and of religious worship" (47). Catholics, it was argued, were not allowed to think for themselves, nor were they allowed to differ in any degree whatsoever from papal doctrine; the church, according to Lyman Beecher, was the "inflexible enemy of liberty of conscience and free inquiry" (82). Catholics were to let their leaders do their thinking for them; they were just to submit: "The Pope thinks for him! It is he (the Pope) who will tell him what he can and should think, and what he can and should believe!" (Chiniquy 67). While Protestant Christian America could tolerate a diversity of churches, a church such as the Catholic Church that proclaimed itself the one true church, could not be accepted in a pluralistic republic (see Lyman Beecher 6668). Nor could the Catholic Church be trusted, as it grew in social and political stature, influencing national elections, running large cities, to be tolerant of its religious neighbors: "She is tolerant," writes Strong, "where she is helpless" (47). At particular risk, in the eyes of pre- and post-Civil War nativists, were America's public schools. The schools were the means by which America's democratic future would be ensured, by educating native-born children and assimilating those foreign-born: "free schools are one of the cornerstones of our government" (Strong 49). Ignoring Catholic objections that a public school that featured a Protestant prayer and the reading of a Protestant version of the Bible was, in effect, making a public education a sectarian one, the Catholic Church was portrayed as being opposed not only to public but to any type of education: "Rome has never favored the education of the masses. In her relations to them she has adhered to her own proverb, "Ignorance is the mother of devotion"” (Strong 50). And even if the Church provided a parochial education, "she has been compelled in self-defense to open schools of her own." In countries where the majority 
religion was Catholic, the true nature of the Church's preference for ignorance could be seen in the high rates of illiteracy: "her own Italy, where seventy-three percent of the people are illiterate."

Second, the Catholic Church was foreign to true-Protestant and AmericanChristian faith. Far from being Christian, the "Romish system" is, according to Edward Beecher, a "spiritual Babylon" (23), a metaphor with multiple connotations including being foreign, ancient (outdated), apocalyptic (Revelation's whore of Babylon), and pagan. "The Church of Rome," writes Chiniquy, "has . . fallen into idolatry" (59). Rather than inculcating faith, Romanism inspired apostasy from faith and an increase in immorality: "Skepticism and infidelity are the legitimate children of unreasoning and superstitious credulity, and the grandchildren of Rome" (Strong 55). Strong warns of the societal danger of this loss of faith: "Apostate Catholics are swelling our most dangerous classes. Unaccustomed to think for themselves, and having thrown off authority, they become the easy victims of socialists or nihilists, or any other wild and dangerous propagandists" (56). However, in pressing the un-Christian and thus antiAmerican nature of Catholic faith, nineteenth-century anti-Catholics had to be careful lest they come across as advocating denying their neighbors their first amendment rights; Lyman Beecher has an imagined interlocutor ask, "But why so much excitement about the Catholic religion? Is not one religion just as good as another?” (79). AntiCatholic authors would at times attempt to distance themselves from making a theological critique of Catholicism, declaiming bigotry, while allowing for a Catholic population in the United States. For example, in Lyman Beecher's worried plea for the American West, which at that time would have included Ohio towns such as Cincinnati 
where he served as a seminary president, Beecher proclaimed that he had "no fear of the Catholics, considered simply as a religious denomination" and that Catholics could "mingle with us as Americans," as long as they and their children "come ... under the full action of our common schools and republican institutions, and the various powers of assimilation" (60). But the lines between Catholic Church and Papal state were always blurry, and a political critique easily blended into a religious critique (or vice versa). Beecher's brand of Calvinism had good "republican tendencies," having "always been on the side of liberty," and even "laid the republican foundations of our nation" (80); but the Catholic "religion never prospered but in alliance with despotic governments has always been and still is the inflexible enemy of liberty of conscience and free inquiry, and at this moment is the mainstay of the battle against republican institutions" (82). Like others over the course of the 1800s, Beecher gives emphasis in his plea to the anti-republican critique, but his sermon for democracy lapses into theology. In so doing, he demonstrates some of the charges that made suspect Catholicism's standing as a truly Christian religion, having deviated from the Protestant, and thus the American, norm. In attacking the view that the Catholic Church is as republican as any other denomination "in our land," Beecher taps into long-bred Protestant fears of and doctrinal disdain for Catholic teachings and practices. He speaks against infallibility, priestly biblical interpretation, the confessional, the granting of indulgences, and the doctrine of purgatory (146-48), but he speaks of them as not only being distinctly Catholic, but also as being not shared by any other church "in our land": "There is in this country, beside the Catholic, no denomination, any principles of whose 
religion is anti-republican" (147). These doctrines fail not only a theological test but a national one as well - they are bad for the church and the state.

Third, the Catholic Church was constructed as being foreign to American values and cultural norms; David Brion Davis (1960) describes mid-nineteenth-century Catholic stereotypes (along with those of Mormons and Masons) as "embody[ing] those traits that were precise antitheses of American ideals. The subversive group was essentially an inverted image of Jacksonian democracy and the cult of the common man" (in The Fear of Conspiracy 12). If George Washington could not tell a lie, a Catholic could not tell the truth. Following traditional anti-Catholic discourse, which took "the honesty of Catholics as its target" (Griffin 44), "all Catholic speech" was held to be "suspect" (45). To be a priest was to be a liar, as ex-priest William Hogan (1845) posits concerning his former colleagues: "They will stop at no falsehood where the good of the church is concerned" (9-10). ${ }^{29}$ If America, via Protestantism's influence, was the land of the free, Catholicism was imagined as despotism incarnate: "Catholicism and Protestantism [were positioned] as analogues for despotism and liberty" (Fenton 5). And so Edward Beecher warns of the possibility that bishops will "to their utmost energy, cooperate with the pope to subvert our civil and religious liberty, and in place of them to establish the intolerant, persecuting, and bloody despotism of the pope" (339). The Catholic Church was a hierarchical structure in a culture that valued egalitarianism, and in a culture that valued the independent man, Catholic clerics called for submission to priestly authority. And its clerical roles upset understood gender roles and American norms about the family. A "female-centered domesticity was a powerful force in both British and American Victorian cultures" 
(Griffin 16); however, nuns were women who could live without a husband or a child: "The existence of groups of women in convents was both a persistent threat and a frightening alternative to the cult of domesticity" (Welter 47). The fear of the convent (or the confessional) perhaps spoke to another underlying value - the need for an open and transparent society. Welter describes the nineteenth-century analysis of American culture by a visitor from Britain, Frederick Marryat: “Americans' fascination for convents ... was explained by ... Marryat, as a national feeling that nothing must be kept veiled, an inherent commitment to freedom of information and open covenants openly arrived at. 'Americans,' he wrote in 1839 , 'cannot bear anything like a secretthat's unconconstitutional"' (48). Nuns were not the only member of the Catholic clergy to upset cultural norms. Celibate, unmarried priests, revered with the title "father" (an "image of a paternity gone awry" [Griffin 95]), also upset cultural expectations of family life: writing of how priests were depicted in 1850s nativist novels, Griffin states, “These 'holy fathers' are usurpers: seeking, by way of a false paternity, to destroy the familial and the democratic structures of American life and, perhaps most ominously, to replace the Nation's Founding Fathers" (95). The Catholic priest could be hypersexualized, with both the confessional and the convent offering opportunities for priestly seduction. In his role as confessor, he could lead women into temptation, preying upon female parishioners in the privacy of the confessional. Or as in Monk's Awful Disclosures, the lecherous priest could turn a house of piety into a house of priestly pleasure, making a convent into a brothel. But if the priest could play the lothario, his male parishioners were to play the woman. Franchot argues that "the alleged psychological seduction of the male by priests" - the Catholic male's "voluntary 
surrender" to the rule of priests_- "violated cultural expectations of masculine autonomy" (171).

\section{CONSPIRACY THEORY}

Overview

Conspiracy theory has attracted the attention of a number of scholars from a wide range of disciplines: Creps (Communication); Fenster (Law); Barkun (political science); Goldberg, Hofstadter, Olmsted (American History); Dean (Cultural Studies); Graumann, Moscovici (Psychology); Jameson (Marxist Theory); Melley, Showalter (English \& American Literature). Despite this widespread consideration in other fields, the conspiracy genre has not received significant attention by rhetoricians (for an exception, see Crowley [2006]). In her (2010) “The Paranoid Style in an Age of Suspicion: Conspiracy Thinking and Official Rhetoric in Contemporary America," Chara Kay Van Horn claims that "[d]espite their current widespread popularity and belief, conspiracy theories and the rhetoric that accompanies them have received only modest attention from historians and even less from rhetoricians" (4). In this section in particular and in my dissertation as a whole, I address this lack of attention to a rhetorical genre that historically has been and continues to be politically popular, pervasive, and for believers, highly persuasive.

In this section, I provide an overview of the place of conspiracy argument in America socio-political discourse. I begin by defining conspiracy theory, considering some of the fundamental rhetorical moves of the genre, including its typically narrative nature and its appeal based in the rhetor's ethos. I then consider its long-established and prominent role in American history, including its use by anti-Catholics and nativists, 
giving notice to Hofstadter's rhetoric of the renegade. In so doing, I am arguing for increased attention by rhetoricians to a genre that has played — and continues to play - a significant role in American argument. Specifically, I am making four arguments. First, conspiracy theory is not a fringe discourse; rather, in the American experience, it is a default argument. Conspiracy charges, allegations, and narratives are a settled and continuing part of America's conversation about itself, with Americans constantly warning of conspiratorial dangers without and within that can end the American experiment. Second, conspiracy rhetoric was not peripheral to but at the heart of the anti-Catholic and nativist message. The anti-Catholic and nativist movements constructed Catholics as foreign and alien to America by conspiracy allegations in which Catholics became a nefarious Other, whose secrecy, plotting, and malevolence were truly alien to the transparent republic whose manifest destiny was to be a (Protestant Christian) light to the world. Third, in light of my first two points, I argue that one cannot understand American argument style in general, and the anti-Catholic and nativist movements in particular, without an understanding and awareness of the conspiracy argument. Finally, in the fourth place, I claim that it is important to understand these arguments in the past, for their rhetoric tends to repeat itself in the present, often with significant political implications. By understanding the workings of conspiracy argument in the past we may understand better conspiracy arguments in the present, for though the targets of conspiracy discourse change, the fundamental rhetorical moves, tropes, and arguments of the genre are repeated. And so, for example, twenty-first-century conspiracy arguments about American Muslims bear resemblance 
to mid-twentieth-century conspiracy fears about Soviet communists, and nineteenththrough twentieth-century fears of Roman Catholics.

\section{Conspiracy vs. Conspiracy Theory}

Legally, a conspiracy is a "combination or confederacy between two or more persons formed for the purpose of committing, by their joint efforts, some unlawful or criminal act" (Black's Law qtd. in Pipes 20). Conspiracies of this nature are a wellknown and accepted fact of life. As Daniel Pipes points out, the courts have indicted people for "various sorts of criminal conspiracy such as bribery, racketeering, price fixing, and drug trafficking" (20-21). And history reveals more than one incontrovertible conspiracy. For instance, while John Wilkes Booth was the only one to shoot Lincoln, a small group of co-conspirators worked with him in this attack on the Union government (that same night, Lewis Powell attempted, unsuccessfully, to kill the Secretary of State). Conspiracies happen.

Although all conspiracy narratives can legitimately be labeled "theories," conventionally only some are. We talk about the Watergate conspiracy—not the Watergate conspiracy theory. Here theory has no noble or scientific connotation-it has just the opposite. Theory here is questionable, irrational, lacking in credibility, evidence, and logic. It is as Marxist literary critic Frederic Jameson labeled it, "the poor man's cognitive map" (356), or in Richard Grenier's phrasing, "the sophistication of the ignorant" (qtd. in Pipes 2). For the conspiracy skeptic the theory in conspiracy theory has the same pejorative nuance as it does for a believer in the divine creation of the earth who dismisses non-theistic evolution as just theory. Peter Knight (2010) reminds 
us, "virtually no one claims to believe in a conspiracy theory as such. The people accused of holding conspiracy theories about the death of JFK . . . are very insistent that they are assassination researchers and not conspiracy buffs. It's only other people who believe in conspiracy theories" (10). Or as John Judge, who prefers to be called an "alternate historian," said, "If other people come up with stuff, it's called history. If we come up with it, it's called conspiracy theory" (qtd. in Knight 10).

Even those conspiracies whose interpretations are supported by wide consensus are still subject to some level of doubt due to the events in question having taken place, at least partially, in the dark. In Conspiracy Narratives in Roman History, historian Victoria Emma Pagán describes the challenge people face in trying to understand in the light what was done in the dark. She opens with two modern illustrations of the problems of the unheard and the unseen, both taken from the world of fact, not fiction: the missing eighteen and a half minutes in Nixon's infamous White House tapes and the Dallas street sign that obscures forever the moment of JFK's assassination in Zapruder's film (1-3). While Pagán does not argue that if only Nixon's conversation had been heard or Kennedy's bullet filmed then "the clouds of conspiracy" would have disappeared, she does argue that it is in these kinds of "gaps" that battles rage. And it is in these gaps that theories arise.

Daniel Pipes, argues that a "[c]onspiracy refers to an act, [while a] conspiracy theory [refers] to a perception" (21). He bluntly dismisses conspiracy theories as "the fear of a nonexistent conspiracy." David Aaronovitch defines conspiracy theory as "the attribution of deliberate agency to something that is more likely to be accidental or unintended" (5). He goes on to explain, "a conspiracy theory is the unnecessary 
assumption of conspiracy when other explanations are more probable." Mark Fenster defines a conspiracy theory "as the conviction that a secret, omnipotent individual or group covertly controls the political and social order or some part thereof" (1). Michael Barkun provides a helpful paradigm for understanding the basic make-up of a conspiracy belief, describing it as "the belief that an organization made up of individuals or groups was or is acting covertly to achieve some malevolent end" (3). Looking at the world through conspiracy-colored glasses (under a homemade helmet of aluminum foil) "implies" a belief in a world "governed by design rather than randomness" (3). In other words, you are not alone if Big Brother is watching over you with an all-seeing eye (which might, in a strange way, be comforting). This "emphasis on design," according to Barkun, reveals itself in "three principles found in virtually every conspiracy theory":

1. "Nothing happens by accident." If something happens it happens because the powers-that-be caused it to happen. They are like the God of hyper-Calvinism in this regard—except that they are not divine.

2. "Nothing is as it seems." Trust no one because what you see is not what you get: "conspirators wish to deceive in order to disguise their identities and activities."

3. "Everything is connected." If you look hard and long enough, you will see how UFOs, the JFK assassination, 9/11, and the current banking crisis are all related. (Barkun 3-4)

A belief in a grand, meta-conspiracy then will typically emphasize secrecy, powerlessness, and malevolence. You cannot have a global conspiracy to promote random acts of kindness; those in on the secret want to use their power to further evil 
aims. It is also important to note that Barkun's meta-conspiracy is a way of looking at reality as a whole: it is a belief system, an ideological apparatus, a world-view.

\section{Conspiracy Rhetoric}

Conspiracy appeals utilize a variety of rhetorical moves to make their arguments. Zarefsky, for instance, describes their ability to "self-seal": "Given surface plausibility, the conspiracy argument's 'theory' of events is almost self-sealing. It is virtually impossible to disprove, and even discrepant evidence can be explained easily, as the work of the clever conspirator who is trying to cover his [sic] tracks" (qtd. in Jasinski 105). And although it is tempting to marginalize conspiracy believers as simply a minority of people who believe in spite of or without any substantial evidence, this easy, quick, and at times arrogant dismissal is a mistake. For believers do not have a lack but an abundance of over-interpreted evidence. Steve Clarke reminds us that since conspiratorial believers are passionately looking to reveal the truth that is out there, "they are typically quite dedicated in their search for evidence ... and are usually able to overwhelm you with a deluge of evidence" (135). In fact, "[c]onspiracy theories invariably seem to be based on more evidence than their immediate rival, the nonconspiratorial 'received view.' This is because," according to Clarke, “they explain all that the nonconspiratorial received view explains ... [,] and then go on to account for the evidence that the received view is unable to explain." In "The Paranoid Style in American Politics," Hofstadter writes of the concern for "facts, or at least of what appears to be facts," among those caught up in the paranoid style: "It is nothing if not scholarly in technique. McCarthy's 96-page pamphlet, McCarthyism, contains no less 
than 313 footnote references, and Mr. Welch's incredible assault on Eisenhower, The Politician, has one hundred pages of bibliography and notes" $(36,37)$.

But while a conspiracy theory is based in an oversupply and not a dearth of evidence, the appeal of a conspiracy theory is not found in the mere accumulation of disconnected, disparate, random pieces of data. What persuades believers are not isolated facts, but facts brought together in a meaningful plot with secretive agents controlling events to bring about an end. Conspiracy theory's narrative framework connects the dots in such a way as to provide meaning and persuade readers. The proof lies not within evidence abstractly conceived or randomly presented; the proof--and the truth--are found within the framework of a compelling story. Conspiracy theories provide their adherents a powerful metanarrative. Hofstadter speaks to this quality when he writes: "The paranoid spokesman sees the fate of conspiracy in apocalyptic terms--he traffics in the birth and death of whole worlds, whole political orders, whole systems of human values" (5).

Fenster describes three "aspects" or "characteristics" that are typical of "the 'classical' conspiracy narrative" (121). Although he is describing, primarily, fictional narratives, Fenster's paradigm is still useful for considering conspiracy narratives, such as Chiniquy's memoir, that purport to be non-fictional; additionally, in the world of conspiracy narratives in general, the lines between fiction and non-fiction are frequently blurred by those who advocate for a conspiracy. First, there is "the role of individual agency within a particular historical situation, as embodied in the protagonist who finds, resists, and destroys (or leads the way to destroying) a conspiracy." According to Fenster, the hero or heroine will find her power in his or her mind--“agency .. .through 
cognition" (126): "The protagonist collects, sorts, and interprets information, and can only begin to act by identifying and correctly unraveling the pieces of information that remain hidden" (125). In fact, many of these protagonists are "professionals in some kind of knowledge industry," and so The Da Vinci Code's Robert Langdon (portrayed in the film version by Tom Hanks) is a professor of symbology at Harvard who is in Paris on a tour to promote his latest book; or in the case of Chiniquy, the protagonist is a seminary-trained priest and preacher. "Faced with imposing, omnipotent mysteries," writes Fenster, "these characters turn their professional or well-developed amateur cognitive expertise toward finding, exposing, and, finally, physically challenging conspiracy" (126).

Second, there is "the dynamic," or what Fenster labels, "the speed and velocity, of the conspiracy narrative, its tendency toward a spiraling and dazzling flow of information about a global array of people, institutions, and events" (121). Fenster argues that the "narrative's dynamic progress emanates from a central paradox at its core" (133). On the one hand, a conspiracy theory reduces a conspiracy spanning time, place, and the globe to "a conflict between a central but secret power and an unsuspecting public." It is this meta-feature of conspiracy theory that makes it so appealing: it explains the world. But on the other hand, it is "an incredibly complex phenomenon that requires great skill and expertise to find and explain.” The relationship between complexity and simplicity helps set the narrative's pace. And the conspiracy narrative's pace of direction is leading it to the defining moment for the protagonist's (and the audience's) understanding. This is the moment when the light bulb turns on, and divergent and contradictory experiences come together for the "aha" 
moment, or as Fenster calls it, borrowing a term from narratologists, the "narrative pivot" (124). "Virtually every conspiracy narrative," he writes, "turns on a particular moment in which the central character, through investigative skill or by sheer luck, uncovers convincing evidence of a conspiracy."

Third, there is "the attempt to contain the narrative's troubling historical situation and incessant movement within a difficult and often disturbing resolution" (121). If a protagonist is dealing with global forces with near omniscience, omni(secretive)presence, and omnipotence, it is hard to bring a narrative to resolution. It is the "simultaneous... moving toward and away from closure and coherence" that "is at the heart of the conspiracy narrative's progression" (142). In the end, it is hard to end (in more than one sense) a conspiracy theory.

Ethos also plays a role in the construction of a conspiracy argument. Earl George Creps ends The Conspiracy Argument as Rhetorical Genre (1980) by calling for further research concerning "the role of the speaker's ethos in defining the conspiracy genre" (199). He briefly sketches three ethos constructions he sees in his dissertation's exemplars-Attorney General (Woodrow Wilson administration) Mitchell Palmer's conspiratorial argument concerning communism and Rush to Judgment author Mark Lane's revisionist history of the JFK assassination. First, the unveilers of hidden plots "adopt the position of crusader," making them "leader[s] of 'the people,", whose "efforts are the only thing that stand between the community and disaster" (208). Second, "conspiracy advocates" position themselves as those with "superior knowledge or abilities." Third, conspiracy believers make allegations of having been the victims of persecution. After describing how these three constructions play out in Mitchell and 
Lane, Creps suggests, “conspiracy advocacy may involve certain consistent patterns of speaker ethos" (210). As will be seen in my analysis of Fifty Years in the Church of Rome, Chiniquy clearly establishes an ethos based on all three elements described by Creps, thus demonstrating its usefulness as a paradigm by which to examine conspiracy rhetoric.

\section{American Conspiracy}

A recent (2011) CCCC panel included two panelists who spoke on their use of the marginal (conspiracy theories, aliens, UFOs, urban legends) in teaching critical thinking. They were asked by an audience member a question whose working premise was that this type of thinking was done by a few. The two panelists did not reject the questioner's premise, but they should have: according to a 2007 Scripps Howard/Ohio University poll, more than a third of Americans believe in a variety of conspiracy theories. Throughout American history, conspiracy fears have been at the center not the periphery (see Levine 11ff.).

While conspiracy advocates are sometimes marginalized as belonging to society's fringe, allegations of conspiracy are, in fact, a default in American argument. As Jodi Dean (1998) argues, “Throughout American history some people have sought to defend what they understood as democracy against what seemed to them hidden machinations of a secret society" (143). And so the Declaration of Independence charges that Great Britain has brought upon the American colonies "a long train of abuses ..., pursuing invariably the same Object," thus "evince[ing] a design to reduce them [the governed] under absolute Despotism" (218); Abraham Lincoln alleges a slave 
power conspiracy against the free states; and then-first-lady Hillary Clinton declares on a national morning television program the existence of a "vast, right-wing conspiracy." In Real Enemies: Conspiracy Theories and American Democracy, World War I to 9/11 (2009), Kathryn S. Olmsted illustrates a typical twentieth-century pattern of a government mishandling a situation, causing conspiratorial fears to arise. And so Wilson's government acts in such a way that in the years following WWI, many believe that it was bankers who colluded with officials to bring on a war that Wilson promised during his 1916 electoral bid we would not enter. Or consider the charges made against FDR that claim that he forced the US into WW II by allowing Pearl Harbor to be bombed—eerily reminiscent of charges made against Bush in the months following 9/11, that he allowed the towers to be bombed, or actually had explosive devices placed in them, so that he could carry out his crusade against Iraq, bringing vengeance for his father's failure to eliminate Saddam. As can be seen in the recent success of the "birther" movement in compelling President Obama to release a copy of his birth certificate in order to quell birthers' qualms about his being a "native-born" American, conspiracy theory has a definite hold on the contemporary imagination (Aaronovitch; Dean; Jameson; Kay; Pipes; Ronson; Taibbi). Jasinski posits, “Americans traditionally have been fascinated by persuasive appeals exploiting the idea that there is a 'conspiracy' ... at work that is ultimately responsible for all of our problems" (103). Indeed, from the beginning, America's self-identity came, in part, through seeing in an other a secret design to subvert us. Although the despot might change over time-British king, Italian pope, Soviet premiere, Iranian imam - the nature of the threat remained the same: to destroy "us" through the infiltration of "them." 
"The essential element in the anti-Catholic attitude," writes Kinzer, "was the idea of a 'conspiracy,' operating by devious and illogical means to attain the end of Catholic supremacy" (31). As can be seen in the titles of some of their movements' books and pamphlets, nineteenth-century anti-Catholicism and nativism thrived on conspiracy fears: Edward Beecher's The Papal Conspiracy Exposed, and Protestantism Defended, in the Light of Reason, History \& Scripture; Samuel F.B. Morse's Foreign Conspiracy against the Liberties of the United States; Philip Phillips's The Popish Intrigue: Fremont a Catholic!!! (1856); (author unknown), Red Cross of Catholicism in America; Startling Expose of an Infernal Catholic Plot. Know-Nothings Set at Defiance. Use of Fire Arms in Cathedrals. Confessions and Secret Correspondence (1854); (author unknown) Secret Instructions to the Jesuits (1831); Oliver E. Murray's The Black Pope: Or, The Jesuit's Conspiracy against American Institutions (1892). The “image of Catholics lurking in secret passages to prey on unsuspecting citizens and induce corruption," writes Justin Nordstrom (2006), "was a prevalent trope throughout American nativism, and it proved to be exceptionally popular as Catholic charitable work increased in the early twentieth century" (99). And one of the central countermeasures against the papal plot was the renegade from the Catholic Church.

In describing the paranoid style, Hofstadter calls attention to "the special significance that attaches to the figure of the renegade from the enemy cause" (34). This "recurring aspect" of American counter-conspiracy movements was found in antiMasonry, which "seemed at times to be the creation of ex-Masons" (34-35); among anti-Mormons, who utilized "the ex-wife from the harem of polygamy" (35); in midtwentieth century "right-wing movements," in which "a particularly important part" was 
"played by ex-Communists"; and for the anti-Catholic movement, there was "the runaway nun and the apostate priest." Robert A. Levine (1989) describes the appeal to readers of renegade rhetoric wrapped within a conspiracy narrative: "Lifting the holy veil of the unholy church, the first-person narrators of these texts ... offered a restless reading public an intensely captivating experience with conspiracy" (110). And during the religious rhetorical wars waged in the nineteenth century between Protestants and Catholics, deserters were a polemic prize. In The Priesthoods and Apostasies of Pierce Connelly: A Study of Victorian Conversion and Anticatholicism, D. G. Paz (1992) argues, "convert clergy played an important role in the denomination warfare of the day" (6). When a priest became a Protestant pastor he "brought a message as it were from the belly of the beast. His testimony validated commonly held beliefs about the phoniness of celibacy, the horrid goings-on behind convent walls, the moral perversions of the Jesuits, the tyranny of the Inquisition, and the general threat that Roman Catholicism posed to Anglo-American freedoms" (6-7). Hofstadter, speaking of renegades more generally, argues that to some extent "the special authority accorded the renegade derives from the secrecy so characteristic of such movements: the renegade is the man or woman who has been in the secret world of the enemy, and brings forth with him or her the final verification of suspicions" (35). And thus famous - or infamousex-clerics like Monk, or Hogan, or Chiniquy provided powerful substantiation of prevalent conspiracy charges, while stoking fears of an outsider taking over the United States and changing America's identity via the false garb of an unholy and foreign church. 


\section{CHARLES CHINIQUY}

\section{Overview}

Although his death was reported in The New York Times ("Father Chiniquy Is Dead"), and while he continues to be studied in connection to Canadian history (Laverdure; Lougheed; Noel), with some occasional attention from American scholars of Lincoln (Fehrenbacher \& Fehrenbacher; George; Hanchett; Neely; Wilson \& Davis), most students of American history, religion, and rhetoric seem to have largely forgotten Father Chiniquy. However, I am arguing for renewed attention to Chiniquy. He provides an excellent opportunity to study the workings of conspiracy rhetoric; although his charges are no longer popularly believed as they once were, Chiniquy's construction of his Lincoln conspiracy theory provides insight into the conspiracy genre, which remains a powerful appeal in contemporary America. Additionally, Chiniquy provides a rich and complicated resource for exploring the nativist and anti-Catholic movement, which sought to create a more Protestant union. Chiniquy's life overlaps with the major moments in the nativist and anti-Catholic movements (he was a contemporary of his fellow Canadian Maria Monk; he emigrated to and lived in Illinois during the rise and height of power for the Know Nothings; and his work was used extensively by the A.P.A.); further, his writings continued to fuel twentieth- and even twenty-first-century nativist and anti-Catholic propaganda.

In this section, I provide a brief biography with an emphasis on the defining campaigns - temperance and anti-Catholicism - and allegiances - Catholicism and then Protestantism — of his life. These points of emphasis are at the heart of my dissertation's primary resource, Chiniquy's Fifty Years In the Church of Rome (1885). As the title 
indicates, Fifty Years focuses on the first part of Chiniquy's life—his life as a Catholic. But this is Catholicism as viewed through the eyes of a devoutly anti-Catholic renegade priest. In addition to an overview of Chiniquy's life as both Catholic and Protestant, I consider Chiniquy's relationship with Lincoln, both as known in history and as popularized in Fifty Years.

There are a variety of challenges involved in trying to construct the historical Chiniquy: there are competing narratives, and as Richard Lougheed (2008) posits, these "presuppose that the other side habitually distorts the truth" (5). Claims made by or against Chiniquy cannot always be corroborated. And historians do not agree. For instance, though Lougheed would not agree with Chiniquy's anti-Catholic polemic, he argues that "the benefit of the doubt" in Chiniquy's own narrative should be given to Chiniquy's version of events, "except where there is compelling proof otherwise" (6). In contrast, Marcel Trudel, author of the standard French historical biography Chiniquy (1955), argues “one will be forced to accept [Chiniquy's] fantastic autobiography" if "one forgets that Chiniquy lied systematically" (qtd. in Lougheed 5-6). An additional challenge is that not all materials written by or about Chiniquy are readily accessible or translated from French into English; Trudel's work, for instance, has never been translated as a whole into English. However, those works of Chiniquy's that made the greatest impact in the United States and are my dissertation's focus (Fifty Years), are available and in English. Finally, a variety of first and second-hand sources, including Lougheed's recent work on the nature of Chiniquy's conversion (which includes substantial biographical material), along with Chiniquy's own Fifty Years, help flesh out the story behind the conspiratorially minded Chiniquy. 


\section{Catholic Temperance Priest}

Charles Chiniquy was born in Kamouraska, a Canadian village on the St.

Lawrence River, roughly 100 miles north and east of Quebec; interestingly, he was born in the same year (1809) as Abraham Lincoln: their brief lawyer/client relationship would ultimately result in a place for French Canadian Chiniquy in American politics. According to Chiniquy, his father, Charles Thélesfor (the son of "the head master [pilot] of the harbour" of Quebec City [Forty Years in the Church of Christ 27]), almost became a priest; however, "a few days before making his vows, having been the witness of a great iniquity in the high quarters of the church, he changed his mind, studied law and became a notary" (Fifty Years 9). Chiniquy's mother Reine Perrault was, as Lougheed points out, "well-connected" (1): "Her sister had married into the prominent Dionne and Chapais families who became seigneurs or landed gentry controlling most of the South shore of the St. Lawrence River below Quebec" (20), and when young Charles was christened, "all the nobility of the region" were present. These connections would prove useful when Chiniquy's father died shortly before Charles's twelfth birthday, with Chiniquy eventually being taken in by his Aunt and Uncle Dionne: "We [his mother and two brothers] came very near starving to death; fortunately, my mother had a sister married to a very rich merchant of Kamouraska, Mr. Dionne, who came to take me as his own child" (Forty Years 28). His relationship with the Dionnes, however, would eventually prove problematic, with his uncle breaking off financial support for Chiniquy's seminary education. The exact cause for this disruption is hard to pin down. Chiniquy labels it a "misunderstanding between myself and my uncle Dionne" (82). 
Lougheed describes how "[t]he early evidence mentions a dispute over money and 'the rest' which is not explained in the only letter [between the director of Chiniquy's college and Bishop Plessis] still extant" (21). Later Catholic opponents would argue that "the fault" was sexual impropriety by Chiniquy toward his uncle's daughter: "Chiniquy was turned out of the house four years later because he was thought to have made indecent advances to one of his adoptive sisters" (Gagnon; ${ }^{30}$ see also Lougheed, who thinks the allegations of sexual misconduct "less likely given the ... continuing relationship between Chiniquy, his aunt and other Dionne relatives" [21], and Sydney Smith, ${ }^{31}$ who believes the charge to be true [16-17]). In his biography, Chiniquy lambasts his uncle, portraying him as an unscrupulous businessman who "had made a colossal fortune at ... [the] expense" of his hometown (392). He positions himself as a hometown hero against his enemy, his uncle, describing himself during his priestly tenure at Kamouraska as one who helped break "the yoke imposed upon them by ... Mr. Dionne" (392), bringing "the monopoly which had cost them so much money" to an end (392-93). His hometown would, in Chiniquy's reckoning, “congratulate[] themselves, that they had, at last, a priest, with such an independent and honest mind, that he would not do them any injustice, even to please a relative in whose house he had spent the years of his childhood" (393). Despite the severance from his uncle's financial assistance, Chiniquy was provided for by others, and able to complete his schooling, whereupon, in 1833, at age twenty-four, he was ordained to the priesthood.

In understanding the faith Chiniquy would eventually oppose, it is important to recognize the dissimilarities between his nineteenth-century, French Canadian Catholic experience and a contemporary, post-Vatican II, American Catholic experience. 
Chiniquy was born, raised, and for most of his priestly career served in a majority Catholic culture in which Protestants were an often despised "other." Berton reminds readers that in attempting to understand Chiniquy, "we tend to forget the almost maniacal bitterness of the Catholic-Protestant division" (138). The dynamics at work in the fear of the Catholic minority by the Protestant majority in the United States also played out in Catholic Canada, only with the roles reversed: in Quebec, the feared "other," against whom a national identity could be constructed, was the minority Protestant. Out of fear of assimilation into Anglican and Anglophile British Canada, French Catholic Canada "deemed" French Protestants as "traitors" (Lougheed 25); in this context, "Protestant" equaled "British." If in the United States, Catholics were pejoratively labeled "Romanists," calling into question their status as true Americans, French Canadian Protestants were "branded as Swiss Methodists"- derived from Swiss Protestant missions to Quebec — "and therefore both foreigners and sectarians" (Lougheed 25). In addition to Protestant scapegoating, over the course of the nineteenth century ultramontane Catholicism significantly affected Quebec culture. The term 'ultramontane' (beyond the mountain) derives from the geography and history of France: someone in France who looks beyond the Alps to the pope and the Holy See is an ultramontanist; he or she is a "strong adherent or supporter of the Papal authority" (Oxford English Dictionary). Although sometimes viewed as primarily a European phenomenon, ultramontanist Catholicism made significant inroads in the church in the United States and Canada: "American Catholics, no less than European, trained their vision across the Alps; for them too, the life of the Church issued from Rome" (Byrne 301). Ultramontanism was "one of the most successful religious movements of the $19^{\text {th }}$ 
century" (Byrne 304), and with its rise came a worldwide resurgence of what would now be labeled "traditional" Catholic piety. John T. McGreevy (2003) describes ultramontanism as "shorthand for a cluster of shifts that included a Vatican-fostered move to Thomistic philosophy, a more intense experiential piety centered on miracles and Vatican-approved devotions such as that of the Sacred Heart, an international outlook suspicious of national variations within Catholicism, and a heightened respect for church authorities ranging from the pope to parish priests. All this was nurtured in the world of Catholic parishes, schools, and associations, whose members understood themselves as arrayed against the wider society" (12-13). The Protestant English conquest of Catholic Canada threatened (or was perceived as threatening) the French language, church, and culture of Quebec. But the Church, according to Lougheed, went from a precarious position following the conquest to a triumphant position, having "managed to fight from extreme vulnerability to acquire all the necessary powers ... to guard its flock" (27). The Church in French Canada, strengthened by ultramontanism, grew in power while French Protestants, liberal anti-clericals, and dissident Catholics weakened: "As political and religious liberty for the Catholic Church increased, social and religious liberty in the broader French society and in the parish decreased." As life in villages centered around the local priest, "[i]t became increasingly difficult to survive in a rural or small town parish, if one disagreed with the priest" (24). This ascendancy of respect for the authority of and devotion to the Catholic Church occurred as young Father Chiniquy found his life's initial calling: temperance. 
In the first half of the nineteenth century, immoderate alcohol intake had become a serious societal problem in North America. Shortly after the British conquest of Canada (1759), the British military governor described the people of Quebec as a sober community (Noel 192); however, that reputation would change. Jan Noel (1990) describes how "the influx of cheap rum from the British West Indies" proved a popular commodity, "one of the few trade items which the relatively self-sufficient farmers were willing to buy," and "[b]y the 1790s travellers were reporting that the French Canadians were heavy drinkers." Imported rum was not the only drink available; alcohol was also produced locally. And with "the introduction of a steam process for distilling," alcohol became cheap: Berton describes conditions becoming such that "[i]t was actually cheaper to drink than to eat," with drinkers "hauling it [rum] home by the cask" (140). "Everywhere," writes Noel, "reasons arose for taking a glass - or four" (193). The challenge facing temperance workers can be seen in the efforts of an early (1837) Canadian temperance society that sought to have its members temper their alcohol intake to only "six small glasses of liquor a day." As a young priest in the mid1830s, Chiniquy himself moved away from moderate drinking to becoming a lifelong practitioner and preacher of teetotalism; in so doing, he discovered the mission that would make him famous.

“Almost single-handedly," Berton writes, "he changed the Quebecois attitude toward strong drink" (141). In so doing, Chiniquy put to great effect his rhetorical education, a training that would have, according to Paul Laverdure, "emphasized exaggeration, expansion, and description" (53). Noel describes Chiniquy's powerful style as one that caused newspaper editors to not print his speeches, apologizing when 
they did for being "unable to capture the effect": "Part of this sprang from the suspense he built up by using stage effects, such as unexpected appearances which led to rumors that he had arrived by miracle" (202). In unprecedented numbers, French Canadian Catholics were moved by his preaching to pledge themselves to abstinence. "Between 1848 and 1851," Noel writes, "thousands of French-speaking Catholics in the Province of Canada came forward in their parish churches to take the temperance pledge" (189). The number of converts is impressive: "By $1850,400,000$ teetotallers, which amounted to nearly half the population of Canada East and a clear majority of the francophone population, had been won" (Noel 201-02). Although he was not the only priest involved in the temperance movement, Chiniquy was the most celebrated: "As word of this conversion [by thousands of Canadians to temperance] reached non-Catholics across North America, the reaction was one of pure astonishment. For several decades evangelical Protestants had labored long and hard to eradicate drunkenness; and now a Catholic priest was securing more converts in a single day than these earlier workers had won with years of steady effort" (Noel 189). But in spite of the significant dent his crusade made to Canada's alcohol industry - the number of gallons produced by distilleries in Canada East dropped from nearly 650,000 gallons in 1847 to around 80,000 gallons in 1850 (205) - the effects of Chiniquy's temperance movement were short-lived. With his immigration to Illinois in 1851, there was a "rapid plunge in enthusiasm" (206), with many forsaking their former pledge. And yet, Chiniquy had gained the praise of the parliament (204), written a best-selling temperance book (Lougheed 307), been blessed by the pope, and given the title, the Apostle of Temperance. Although as Noel argues, cultural factors, including the ascendancy of 
ultramontanism, certainly played a significant role in his success, Chiniquy had become a national hero.

And yet at the height of his popularity and influence, Chiniquy was sent to Illinois. As with other moments in the Chiniquy history, there are conflicting narratives based on less-than-ideal evidence. Chiniquy himself portrays this in terms of Catholic jealousy and plots. However, later anti-Chiniquy Catholics framed his move from Canada to Illinois as a result of his arrogance, insubordination, immorality, and other character flaws (Smith; Trudel); in this view, Illinois was one last chance to redeem Chiniquy. Regardless, besides hurting the Canadian temperance movement, the move would eventually hurt Chiniquy's standing as a hero for French Canadians, leading as it did to not only to his Protestant conversion, but also to his pro-immigration policy concerning the Francophone population. How could one be true to his French-cultured homeland while advocating a major resettlement in its English-speaking neighbor? In terms of his subsequent importance in American socio-political discourse, the Chiniquy immigration is the significant moment, for it is in Illinois that Chiniquy will not only discover the religion that will dominate the second half of his life but also the American president whose coattails he will ride to fame.

\section{Anti-Catholic Presbyterian Preacher \& Author}

After moving to Illinois, Chiniquy became the defendant in a case brought against him by Peter Spink, a land speculator, who accused the priest of perjury (George 22). At that time, Abraham Lincoln was a prominent attorney, based in Springfield, Illinois, but who also, every spring and fall, represented clients in the several counties 
that made up Illinois's Eighth Circuit. In Life on the Circuit with Lincoln, Henry Clay Whitney, one of Lincoln's fellow lawyers, remembers that Chiniquy had accused Spink, a member of one of Chiniquy's parishes, of perjury in a trial (54). ${ }^{32}$ In his review of Chiniquy’s relationship with Lincoln, Joseph George Jr. (1976) cites the official complaint sworn by Spink on February 3, 1855, in which Spink calls Chiniquy's allegation against him "false and malicious," adding that Chiniquy's statement against him was not the first. Further, Spink claimed that Chiniquy's slander had been bad for his business, with him being unable "to do business as before, wherefore he was greatly injured and sustained great damage" (qtd. in George 23). The case did not proceed smoothly--there was a change of venue from Kankakee to Urbana Illinois, which was done at Spink's instigation, out of concerns that the Kankakee judge was prejudiced against him. The first trial was a mistrial, and the second resulted in a hung jury (George 23). When Lincoln was eventually engaged by Chiniquy (after the second trial according to George), he "finally effected a compromise, after a jury had been chosen: and the case was dismissed" (Whitney 75). While the Spink case might have been settled, eventually Father Chiniquy would use it in his own prosecution of the Roman Catholic Church.

By the beginning of the Civil War, Charles Chiniquy had changed religious sides. In 1858, Chiniquy the Catholic became Chiniquy the Protestant; Father Chiniquy became Reverend Chiniquy. The exact motivation for his conversion remains controversial, with competing interpretations: the traditional Protestant version sees him as a saint, convinced of the evils of Catholicism; the traditional Catholic view portrays him as hypocrite, guilty of sexual immorality, and motivated by arrogance and greed 
(Lougheed; Smith; Trudel). But not only did the former priest become a Protestant, he also became a Protestant with a polemical purpose: free the Catholic people from the despotic pope in Rome. This new stance would make him a hero to some Protestants, and a horror to French Canadian Catholics; the priest whose picture once hung in their homes (Noel 201) now "was considered a monster" and "compared to the devil and excrement" (Laverdure 42). And the invective he received, he freely returned; for although Chiniquy may have changed theological states, the inflammatory rhetoric he had honed in his anti-alcohol campaign remained firmly on display--with opponents typically accused of being drunkards (Laverdure 47). He continued to put the showmanship he had used while a temperance man to good use as an anti-Catholic polemicist. In Montreal he made mockery of the foundational Catholic doctrine of transubstantiation by "consecrat[ing] wafers of bread only to crumble them, dump them on the ground, and trample them under foot" (Choquette 188). In light of this deliberate sacrilege, one can understand why the Reverend Chiniquy's preaching was sometimes met by riots. His lifelong combativeness led one newspaper obituary to suggest a strange disappointment for the deceased Chiniquy, who died at home just a few months shy of his ninetieth birthday: "The thought that he was never even once killed in a religious riot must have embittered his last hours" (qtd. in Laverdure 56).

While in his mid-seventies, with his life's calling firmly ensconced as an opponent and no longer a defender of the Catholic Church, Chiniquy published his autobiography, Fifty Years in the Church of Rome (1885), which alleged a Vatican connection to the Lincoln conspirators. Prior to Chiniquy, others had also saw a 
connection between the Church and the assassination; the Catholic faith, both alleged and actual, of the conspirators caught the attention of many in a nation still very much susceptible to nativist, anti-Catholic prejudice. Within days of the murder, "Assassination in History," which would eventually be featured in several Northern newspapers, appeared in the Cincinnati Commercial. It "chronicle[d]" the "nefarious political behavior by European Catholics over the centuries, including assassination of kings and queens" (Zanca 85). While not the first to allege a nefarious plot between Pope and actor, Chiniquy's Fifty Years was, according to Hanchett, the first "systematic development" of the Lincoln murder as a "Catholic grand conspiracy" (234). But even more sensational than Chiniquy's charge is his star witness: Abraham Lincoln.

Chiniquy describes a personal relationship with the president that goes beyond one-time lawyer/client to friendship and closest of confidantes. According to Chiniquy, beginning with the Spink trial and continuing through three reputed visits to the White House, Lincoln becomes Chiniquy's "most devoted and noblest friend I ever had" (661), and Chiniquy becomes for Lincoln, "almost the only one with whom I speak freely" about the Roman church and the American republic (715). In conversations that can become monologues that stretch on for page after page, Chiniquy shares with and hears from Lincoln a message that sounds much more like an anti-Catholic former priest than it does the sixteenth president. Lincoln's contemporaries and historians have had a notoriously difficult time determining the exact nature of his personal religion--or lack thereof; but in Chiniquy's telling, the president becomes not only a devout Christian but also an avid foe of the Catholic Church. What follows (in abbreviated form) is Chiniquy's version of his meetings with Lincoln. 
During Chiniquy's supposed first visit in August 1861, President Lincoln suggests that Chiniquy go to Europe as a secretary to an ambassador so that he might spy on the Vatican and reveal more of its plots. Lincoln even suggests that one day Chiniquy could be made an ambassador, seemingly oblivious to the reaction Catholics in Europe and the American electorate might have to the prominent placement of an eminent "apostate" (694). Chiniquy declines. But while Chiniquy will not be his papal spy, he will be Lincoln's anti-Catholic mentor. Lincoln asks why “[a] great number of Democratic papers have been sent to me, lately, evidently written by Roman Catholics, publishing that I was born a Roman Catholic" (693-94). It is a charge that Lincoln scornfully denies: "it is a lie. Thanks be to God, I have never been a Roman Catholic" (694). Chiniquy goes on to explain that the Catholic media is using this to stoke up antiProtestant fears--and assassination plots--against the apostate president: "in the Church of Rome, an apostate [. . .] has no right to live." Lincoln does not dismiss Chiniquy's lesson, but agrees: "I know that they are not imaginary dangers" (696).

At this point, Lincoln becomes the teacher. As Chiniquy has explained Rome's past and its probable future actions, Lincoln explains contemporary events--the Civil War, Lincoln knows, is nothing more than a Catholic plot against American liberty. "[I]t is not against the Americans of the South, alone, I am fighting," Lincoln states, "it is more against the Pope of Rome." While Lincoln recognizes the loyalty of some Catholic Americans, they are an "insignificant minority" compared to the "immense majority of Roman Catholic bishops, priests and laymen," who "are rebels in heart, when they cannot be in fact" (697). Lincoln's rhetoric now shows a real malice toward almost all Catholic ministers. Using the French revolution as his text, Lincoln explains 
that he now "understand[s] [. . .] why the patriots of France [. . . were forced to hang or shoot almost all the priests and the monks as the irreconcilable enemies of Liberty." And while Lincoln hopes the United States will not have to choose between national liberty or the execution of priests, if it does have to make this choice, he can justify the ways of God to man: "Their extermination in France, was one of those terrible necessities which no human wisdom could avoid; it looks to me now as an order from heaven to save France."

The second alleged visit, in June 1862, allows only a brief greeting; it is the third visit that enables Lincoln to show charity to none who are true Catholics. Chiniquy acts as Lincoln's Cassandra, prophesying his death, and again the cause will be Catholicism. Lincoln agrees, and says that he will die. But his death will be for the cause of the nation's sins and God's justice. Lincoln will be the nation's sacrificial lamb; but he will be a lamb put to the slaughter by the occupant of the chair of Saint Peter.

However, before he becomes the nation's means of atonement, Lincoln the lawyer issues one more legal interpretation:

Till lately, I was in favour of the unlimited liberty of conscience as our constitution gives it to the Roman Catholics. But now, it seems to me that, sooner or later, the people will be forced to put a restriction to that clause towards the Papists. Is it not an act of folly to give absolute liberty of conscience to a set of men who are publicly sworn to cut our throats the very day they have their opportunity for doing it? Is it right to give the privilege of citizenship to 
men who are the sworn and public enemies of our constitution, our laws, our liberties, and our lives? (704-05)

If Lincoln must leave the world for a heavenly home, the Catholics must leave the United States for a Roman hell.

Although Chiniquy's narrative of paranoid, intolerant president led Lincoln historians, according to Don E. Fehrenbacher and Virginia Fehrenbacher (1996), to label Chiniquy, "the biggest liar in Lincoln literature" (98), others have been far more receptive. First published in English in 1885, his autobiography was a best seller “reach[ing] a fortieth edition by 1891” (Kinzer 31). In "From Maria Monk to Paul Blanshard: A Century of Protestant Anti-Catholicism” (1987), Barbara Welter describes the popularity of autobiographies by former priests. Beginning in the 1830 s, these "[e]x-priest autobiographies ... had successive waves of popularity during the nineteenth century," with Charles Chiniquy being that century's "most widely published priestly recusant” (61). Chiniquy was the Maria Monk of post-bellum America. And with Lincoln as its star witness against the alleged diabolical doings of a Roman priesthood, Chiniquy's conspiracy narrative was widely used to promote a nativist and anti-Catholic agenda. Kinzer describes how "[t]he growing anti-Catholicism" during the 1890s "fed on" Fifty Years, making it "probably the first-ranking, certainly no less than second, of all anti-Catholic best sellers." As Kinzer states, "[Chiniquy] was the source for the legend that ... Lincoln was aware of the 'Catholic menace,' asserting that Lincoln had told him during a visit to the White House [... ], 'I do not pretend to be a prophet. But though not a prophet, I see a dark cloud on our horizon. And that dark cloud is coming from Rome"” (31-32). Kinzer remarks, "This quotation was used 
constantly throughout the ensuing [Nativist] crusade, and Lincoln became a brooding spirit whose premonition was a warning to his fellow countrymen" (32).

The Lincoln of record is, of course, not the Lincoln of Chiniquy. In 1924, historian Carl Russell Fish responded in The American Historical Review to an antiCatholic pamphlet, "circulated by the million[s]," that contained a Chiniquyesqe Lincoln quote. "Students are perfectly well aware that no such quotation is to be found in the works of Lincoln," he wrote, "they know that the spirit of the quotation is contrary to the whole character of Lincoln's thought and expression." When Robert Todd Lincoln was asked in 1922 by a Catholic magazine about alleged anti-Catholic feelings in his father, he responded, "I do not know of any literature in which my father is quoted as attacking Catholics and the Catholic Church. Of course, in the years his name has been a peg on which to hang many things" (qtd. in George 20). The Lincoln of Fifty Years was not the Lincoln who, when asked by his closest friend, Joshua Speed, whether he was a nativist, denied and denounced nativism:

As a nation, we began by declaring that "all men are equal." We now practically read it "all men are created equal, except negroes." When the KnowNothings get control, it will read "all men are created equal, except negroes, and foreigners, and catholics." When it comes to this I should prefer emigration to some country where they make no pretence of loving liberty--to Russia, for instance, where despotism can be taken pure, and without the base alloy of hypocrisy. (qtd. in Neely 174). 
While Chiniquy has largely disappeared from the narrative of American history, his charge has remained alive, resurfacing at times when Americans, yet again, feared the Catholics among us, such as when John F. Kennedy ran for office in 1960. Even today, the title is in print in an abridged form, and a comic book adaptation of the Chiniquy autobiography (Jack T. Chick 1981) is for sale, with the comic's cover revealing its main selling point: Lincoln's slumping neck, Booth's hand holding a smoking gun, all set against the backdrop of the Vatican flag colors and Saint Peter's Cathedral, under the name, "The Big Betrayal."

In his version of Lincoln, Chiniquy followed a well-worn path among believers-he created the president in his image. Lincoln's lack of membership in any denomination, coupled with a discourse laced with Scriptural language and references to providence, but not necessarily Jesus, joined by a seeming buffet of anecdotes concerning practically the religion of a reader's choice, has made President Lincoln into Father Abraham. In defining the man who saved the union as an anti-Catholic Evangelical, Chiniquy offered nativists then and now the ability to take Reformation Age-old charges and drape them with an American flag and, by so doing, reframe the American Experiment into an extension of Calvin's Geneva.

${ }^{1}$ Rhetorical scholars, for instance, consider ethos when examining important public addresses and documents. Thus Martha Cheng (2012), for example, considers how then Secretary of State Colin Powell successfully "reconstituted" his ethos from skeptic to proponent in his famous 2003 speech to the United Nation's Security Council urging military action against Iraq, arguing that his changed ethos. Or Carolyn R. Miller (2004) explores the complex and conflicting role ethos plays in an early example of risk analysis - the 1975 Reactor Safety Study (RSS) by the Atomic Energy Commission. Recent scholarship, however, does not limit itself to analyzing famous speeches or government documents. Judy Holiday (2009), for example, explores ethos as ethics in a postmodern world, arguing that both "the study and teaching of rhetorical invention... theoretically should be indissociable from the study of ethos or ethics (and, by 
extension, politics)" (390). And Dana Anderson (2007) assesses, in part, the relationship between ethos and personal identity as persuasion strategies, which he describes as related yet distinct concepts, both constructed in discourse. Consider also Michael Bernard-Donals's (2000) examination of the "truthfulness" of trauma narratives and the credibility of their witnesses, in which he argues for an "indicative" view in which "the ethos of the witness is established through an ability to indicate the event as it exceeds our ability to write or name it" (580). And as one final example, Patricia Bizzell (2006) adds to feminist scholarship by considering how one of the nineteenth century's most influential female orators, Woman's Christian Temperance Union president Frances Willard, became successful, in part, through her tapping into the ethos of the female Methodist preacher.

${ }^{2}$ See Todd Frobish (2003) for a description of a Homeric theory of character/ethos based on speeches in the Iliad and its possible contribution to Aristotle's view.

${ }^{3}$ See Brooke Rollins (2007) who grants Isocrates's "essentialist sentiments" (14) while arguing that his "belief that essence can be transformed through rhetorical training is revolutionary" (15).

${ }^{4}$ Consider Coretta Pittman's (2007) critique of classical Aristotelian ethos as placing an unfair rhetorical burden on nineteenth- and twentieth-century African-American woman, positing that it does not make space for their experiences and thus marginalizing them for not having a majority-culturally approved ethos/character.

${ }^{5}$ See also Frobish for how Homer's understanding of character in the Iliad differs from Aristotle's. Without discounting discourse, Homer's characters' character is displayed more through action - especially on the battlefield - rather than through words (19-20). ${ }^{6}$ Although Chamberlain focuses on ethos outside of its rhetorical or "transferred" use (108), his overview is useful for the history of the word in general.

${ }^{7}$ On the relationship between ethos/character in the Ethics compared with that in the Rhetoric see Cherry 387-88; Halloran 60-61; Smith.

${ }^{8}$ Reynolds cautions, however, that we should not read Halloran's depiction of classical age "people gathering together in a public place, sharing experiences and ideas" as depicting a past utopia: "remember that in classical Greece and Rome, slaves and women were not welcome to share in the public space of experiences and ideas" (329). Ethos/character, then, is subject to the limitations of a community, too; the character of ethos is not necessarily or essentially fair.

${ }^{9}$ See Jerry Harvill's (1990) argument against a pragmatic ethos in the Rhetoric; but see also André Resner's (1999) critique of Harvill, pp. 20-24.

${ }^{10} \mathrm{Schmertz}$ defends this as possibly arising from "many of the classifications and taxonomies" being "in the process of development in the Rhetoric" (85).

${ }^{11}$ Institutes of Oratory 1.2.3.

12 On Christian Doctrine 4.59.

${ }^{13}$ Kennedy (1999) comments that Augustine originated the view, which "has reappeared in modern criticism ... that the value of a work of art is not dependent on the morality of the author" (180).

${ }^{14}$ An appeal to logos is also involved. In "The Paranoid Style in American Politics," Richard Hofstadter labels "impressive" and "almost touching" the "concern with factuality" found in the writings of those who caught up in the paranoid style (37). 
${ }^{15}$ Having been brought up in a more ecumenical age, modern Americans may find it challenging to grasp the previous intensity of antipathy between Protestants and Catholics. But there was a time when a visiting Canadian priest burned 42 Protestant Bibles, the gifts of a Protestant Bible society to local Catholics, in upstate New York (1842; Billington 157-58, 165), and a ten-year old, Catholic boy in a Boston public school had his hands viciously whipped for thirty minutes for the crime of refusing to repeat the Protestant version of the Lord's Prayer (1859; McGreevy 7-11). As Ryan K. Smith (2006) demonstrates in his work on Gothic architecture and anti-Catholicism, it was an animosity that stretched to the top of their steeples: the anti-Catholic crowds cheered when the cross on top of St. Michael's Catholic Church, having been set on fire, crashed to the ground during the infamous 1844 Philadelphia riots (1).

${ }^{16}$ Donald W. Sweeting (1998) speaks of the Evangelical Protestant movement and the Catholic Church as "large houses with many rooms" (13). And Garry Wills (2007) describes American anti-Catholicism as having "a long but not a unitary history," a history under which it appeared in many guises (50). (See also Sweeting's threefold division of nativistic, patriotic, and theological anti-Catholicism [39-46].) ${ }^{17}$ Margaret C. DePalma's (2004) Dialogue on the Frontier: Catholic and Protestant Relations, 1793-1883 argues that the Catholic/Protestant divide in the American west featured cooperation as well as opposition. Jay P. Dolan (1987) describes a period of liberality and amiable relations following the Revolutionary War (73-74; see also Marchant 54-55). Susan M. Griffin (2004) writes of numerous Protestants who condemned the extreme anti-Catholic rhetoric found in nineteenth-century fiction (12). However, even those who deplored rhetorical excess sometimes committed it: see Lyman Beecher's (1835) critique of unchristian polemic in the midst of his conspiratorial diatribe against the Catholic Church (Plea for the West 66-7). ${ }^{18}$ Charles R. Morris (1998) summarizes the challenge facing a Roman Catholic in the United States: "The fluidity, the individualism, the frankly experimental style that define the American character are in direct opposition to many of the central components of Catholicism - the notion of dogma, the principle of authority and hierarchy, the medievalisms" (vii; see also Gjerde 12, 15, 61-95, 138-75).

${ }^{19}$ Father John W. O'Malley opines in a recent (October 10, 2012) op-ed for The New York Times that prior to Vatican II, "Catholics were not only forbidden to pray with those of other faiths but also indoctrinated into a disdain or even contempt for them" (A31). ("This was," he adds, ". . . a two-way street.") Dolan's "Catholic Attitudes toward Protestants" describes how Catholics were trained to see Protestants as ignorant of the one true faith, whose own faith was not truly efficacious in terms of salvation. As the First Vatican Council stated, "outside the [Catholic] church no one can be saved . . . what is not in this ark will perish in the flood" (qtd. in Dolan 76). (See also Welter [4445] for a Catholic response to Protestant views.)

${ }^{20}$ Although anti-Catholicism no longer has the cultural capital it once possessed, it has not entirely disappeared from American life (Malcom; Massa; Neuhaus; Jenkins; Paterson). Fundamentalist Jack Chick continues to publish titles including "Are Roman Catholics Christians?," The Secret History of the Jesuits, and a pamphlet opposing transubstantiation called "The Death Cookie." In keeping with Puritan primers from colonial days that aligned Catholicism with non-Christian heathenism or anti-Christian 
heresy (Billington 347), Frances R. A. Paterson (2003) demonstrates how some contemporary conservative Christian textbooks utilized by private academies and homeschoolers still display anti-Catholic bias; one secondary English textbook, for example, describes post-Vatican II Roman Catholic officials as having engaged in ecumenical talks "with liberal Protestants" for the nefarious purpose of "undoing the work of the Protestant Reformation" (qtd. in Paterson 108). Contemporary antiCatholicism, however, need not be limited to the fundamentalist margins. Richard John Neuhaus (1989) accused the editors of the New York Times of possibly resurrecting "the anti-Catholic bigotry that many had thought had been laid to rest in the last several decades" ("Those Turbulent Bishops," National Review, 12/31, p. 32). Philip Jenkins (2003) maintains that since the 1970s there has been a rise of a "new liberal antiCatholicism" (209). (See also William B. Prendergast [1999] 17-18 on the secular nature of modern anti-Catholicism.) And Arthur Goldwag (2012) argues that Dan Brown's recent blockbuster novels Angels \& Demons (2000) and The DaVinci Code (2003), both of which were made into mainstream Hollywood films, "revived some of the most egregious anti-Catholic stereotypes of the Know-Nothing era" (7). Allison O'Mahen Malcom (2011) argues that an increasingly secular culture has led former denominational opponents of the Church to acknowledge it, albeit reluctantly, as a friend and not a foe; they may continue to disagree about soteriology (how one is saved), but on social issues (abortion, gay marriage) they share common beliefs (29394; Sweeting 27). A shared enemy has made conservative Catholics and Protestants into political bedfellows.

${ }^{21}$ See Bennett 20; Brown 20; Fenton 4-5, 11, 17-35; Franchot xviii-xxvii, 3-15, 88; Gjerde 20-60; Higham 6; Levine 9-10; 107; Maier 16; McConville 7, 79, 112-19; Malcom; Marchant.

22 http://archive.org/details/historyofcatholi03shea

23 The following all describe the importance of Monk: Bennett 42; Billington 99; Franchot 154; Griffin 18; Massa 22.

${ }^{24} \mathrm{http}: / /$ archive.org/details/pleaforwest00beec

${ }^{25} \mathrm{http}$ ://books.google.com/books?id=iVcYAAAAYAAJ\&printsec=frontcover\#v=onepa ge\&q\&f=false

${ }^{26}$ Fulton opens his (1888) Washington in the Lap of Rome with a fascinating argument concerning a secret telegraph wire between President Cleveland's White House and Cardinal Gibbons's Baltimore home: "If it is not true, as is charged, that a private wire runs from the White House . . . to the Cardinal's Palace, ... and that every important question touching the interests of Romanism in America is placed before his [the Cardinal's] eye, ... it is true that the Cardinal is a factor in politics" (vii). This allegation of illicit tampering in political affairs was made often enough that Cleveland felt obligated to publicly repudiate it (Kinzer 267)

${ }^{27} \mathrm{http}$ ://books.google.com/books?id=2iIQAAAAIAAJ\&pg=PA75\&dq=Rome + or + Amer ica, + Which?+1895\&hl=en\&sa $=$ X\&ei $=$ uYzEUcyyDcry0gGvn4HwAg\&ved=0CFsQ6A EwCA\# $\mathrm{v}=$ onepage $\& \mathrm{q} \& \mathrm{f}=$ false

${ }^{28}$ See also Bennett; Franchot; Griffin; Kinzer; Nordstrom; Roy; Schrag; Schultz; Wallace.

${ }^{29}$ http://archive.org/details/synopsisofpopery00hoga 
${ }^{30} \mathrm{http}: / /$ www.biographi.ca/en/bio/dionne amable 8E.html

${ }^{31} \mathrm{http}: / /$ openlibrary.org/books/OL19174276M/Pastor_Chiniquy

32 http://archive.org/details/lifeoncircuitwit00whit 


\section{CHAPTER TWO}

\section{THE ETHOS OF A RENEGADE CONSPIRACIST: CHINIQUY'S SELF CONSTRUCTION IN FIFTY YEARS IN THE CHURCH OF ROME}

In this chapter I begin my case study, analyzing my primary text, Fifty Years in the Church of Rome, through the lens of ethos construction. As noted in the previous chapter, conspiracy argument via the person of the renegade has played a significant role in the anti-Catholic and nativist movements. Indeed, numerous alleged and actual ex-nuns (Monk, Reed, Shepherd, O’Gorman) and ex-priests (Hogan, Randolph, Slattery) used their prior life experience as Catholic clerics to persuade Americans of Jesuit plots against a Protestant nation. Although they used a variety of arguments, not all of which explicate their personal experience in the Catholic Church, the credence given them ultimately rested on their character/ethos. In renegade rhetoric, it comes down to the speaker/author's ethos: we believe the charge because we believe and trust in the person and his/her character. How does this dynamic work in Chiniquy's autobiography? How is the renegade ex-priest constructed and presented so as to persuade the American public that Chiniquy should be believed when he makes his antiCatholic conspiracy argument?

In this dissertation I am arguing for increased attention to the role ethos plays in conspiracy narratives in general and in the conspiracy arguments of anti- 
Catholic renegades in particular, positing that ethos construction plays a much more significant role in conspiracy persuasion than typically considered. Of course, it is a commonplace to recognize the importance of ethos in any argument; after all, it is one element in Aristotle's long-lived, nearly canonical persuasion triad. However, the role of ethos in conspiracy persuasion has been overlooked among rhetoricians and other students of this politically and socially significant—as well as prevalent—-type of argument. Greater attention by far has been paid to the individual and group psychology of conspiracy believers. And rebuttals to conspiracy narratives often focus on the logos—or lack thereof—in the allegation. In his analysis of Lincoln's famous “House Divided" speech, in which the then senatorial candidate Lincoln alleges a slave conspiracy against the free states, David Zarefsky describes how some scholars limit their analysis to the "seemingly simple factual question of whether the conspiracy charges were true" whereas "[c]learly more was at issue" ("Abraham Lincoln" 33). To be fair, the way believers formulate conspiracy narratives almost naturally leads to these types of responses and analyses. For instance, concerning the appeal to logos, Barkun points out that conspiracy believers typically clothe their claims in the apparatus of rational, logical argument based on an overwhelming amassing of proof: "Conspiracy theories purport to be empirically relevant; that is, they claim to be testable by the accumulation of evidence about the observable world" (6-7). In essence, they present their argument as a logical matter, prodding those who examine their arguments to respond in kind. Hence, 9/11 "truthers" argue that a missile rather than an airliner hit the Pentagon, leading to a rebuttal focused on eyewitness testimony of a plane hitting the structure. As important as this type of response is, there are other qualities that help 
or hinder the rhetorical success of a conspiracy narrative - such as the careful construction of ethos. Trust — both absent and present - is at the heart of conspiracy allegations. As Barkun reminds us, “"Trust no one' was one of the mantras repeated on The X-Files, and it neatly encapsulates the conspiracist's limitless suspicions" (2). For a conspiracy-believing community, a rhetor must demonstrate that he or she is one who can be trusted. He or she must demonstrate and construct an ethos that is credible, reliable, valuable, and above all trustworthy.

This chapter provides an important step in my dissertation's overall argument by examining how ethos is constructed in the foundational text for Chiniquy's Lincoln conspiracy theory, Fifty Years, so as to make him worthy of trust among those inclined to listen to and be persuaded by his case. The text does this in a variety of ways, but I will concentrate in particular on five specific ethos constructions. Ethos construction, of course, is not the only factor in Chiniquy's appeal or in the building of trust; he also makes appeals to pathos and logos. But without a careful attention to ethos, Chiniquy's diatribe against the Catholic Church, including his allegations of a Jesuit plot against the Union and its redeemer president, would not have the credibility needed to persuade his audience. Keep in mind that due to the covert nature of the alleged Catholic crimes, Chiniquy cannot conclusively prove his case beyond a shadow of a doubt; his charges, to some extent, cannot be proved or disproved - a problem and an advantage shared by other conspiracy narratives. Zarefsky states, "a conspiracy charge is virtually impossible to prove" due to the nature of the plot it alleges: "It deals with acts committed in secret to achieve a purpose usually only known through inference" (Lincoln, Douglas, and Slavery 106). As a result, "it is virtually impossible to disprove," for "[o]ne cannot 
prove a negative"; "moreover," he continues, "acts or events that seem to challenge the existence of the conspiracy can be reinterpreted as the work of clever conspirators to conceal their true intentions" (106-07). Barkun also describes an evidentiary paradox in which "the obsessive quest for proof masks a deeper problem: the more sweeping a conspiracy theory's claims, the less relevant evidence becomes, notwithstanding the insistence that the theory is empirically sound. This paradox occurs because conspiracy theories are at their heart nonfalsifiable" (7). Barkun elaborates on their nonfalsifiable nature in terms that point back to the need for trust: "No matter how much evidence their adherents accumulate, belief in a conspiracy theory ultimately becomes a matter of faith rather than proof." Although an advocate for conspiracy may present proof, he or she is asking, ultimately, that one take a leap of faith — and in renegade rhetoric, like Chiniquy's, the advocate of conspiracy is asking the audience for faith in the renegade. Where strict proof does not exist or can be explained in multiple ways, ethos fills the gap and builds a bridge, allowing for trust and persuasion. As Aristotle argued, when describing it as "almost ... the most authoritative form of persuasion," ethos proves persuasive "on all subjects in general" but "completely so in cases where there is not exact knowledge but room for doubt" (page 38; 1.2.1356a.4). Ethos provides the trust to believe what can be neither falsified nor entirely proven, where knowledge lacks and doubts find room. Ethos is key to conspiracy argument.

In considering Chiniquy's ethos, I organize this chapter into two main sections. First, although my project as a whole (and this chapter in particular) tends to focus on the intratextual or "internal" ethos/character of Chiniquy as constructed within the text of Fifty Years, I begin by examining the extratextual or "external" (to the book's 
autobiographical narrative) ethos of Chiniquy. Here I consider Chiniquy's reputation that precedes the publication of his book but as alluded to in what Gérard Genette has termed the "paratext." Genette (1997) describes a "literary work" as a "more or less long sequence of verbal statements that are more or less endowed with significance" (1). This extended, written text or narrative, however, is seldom delivered without "verbal or other productions, such as the author's name, a title, a preface, illustrations": these elements make up a book's paratext. The paratext "surround[s]" and "extend[s]" the main text or narrative thus "enabl[ing] a text to become a book and to be offered as such to its readers" (1). It may include verbal elements, sections of actual text within the pages of the book (Genette specifically mentions, as an example, a book's preface); it can contain nonverbal elements, such as a frontispiece; and it can also contain elements outside of the book itself, such as advertisements for the book. ${ }^{1}$ The combined elements of the paratext "constitute[] a zone between text and off-text, a zone not only of transition but also of transaction" in which the author (and publisher) take aim at a "better reception for the text and a more pertinent reading of it" (2). The "author and his allies" use this "strategy" in order to bring about a reading of the text more in alignment with authorial intention. ${ }^{2}$ For my purposes, I consider how the paratext acts as a rhetorical transaction, helping establish a persuasive ethos for Chiniquy prior to the actual narrative —and argument—of the book: the paratext constructs an ethos that highlights his renegade status and aims to influence how readers read Fifty Years. I examine verbal and nonverbal elements such as the frontispiece, title page, and preface, suggesting how they construct an extratextual or external ethos based on Chiniquy's prior reputation and character. The paratext also extends beyond the printed page. 
Genette writes of "distanced elements ... located outside the book" (5), dividing paratextual elements into two broad categories based on their "location" to the book itself (4): the peritext and the epitext. Elements "[w]ithin the same volume," such as a title page, are the "peritext," while elements or "messages" at some remove ("located outside the book") such as a newspaper interview with the author, comprise the “epitext” (4, 5). "[A]ny paratextual element," writes Genette, "not materially appended to the text within the same volume but circulating, as it were, freely" is the epitext (344). Or to put it perhaps more simply, the peritext is within, and the epitext is without. In this chapter, I take note of the peritext, and via an examination of this "heterogeneous group of practices and discourses" (2), I consider the external ethos of Chiniquy. ${ }^{3}$

Second, having examined Chiniquy's extratextual or external ethos via the paratext, I then consider his ethos as constructed within the text-his intratextual or "internal" ethos. I analyze Chiniquy's ethos construction in Fifty Years, initially using the three-fold prism suggested by George Creps for understanding how conspiracy proponents typically position themselves - as crusaders, experts, and victims. Chiniquy connects to his audience via each of these three roles, but he also adopts two other significant postures not described by Creps. First, Fifty Years positions Chiniquy as a visionary, as someone who hears the voice of God and, eventually, sees the Son of God. Chiniquy describes a "mysterious" voice that helps his Catholic self see the errors of the Roman way. This move enables him to call on the ultimate witness for his Christian audience - God himself. Second, Fifty Years positions Chiniquy as an insider within the conspiratorial institution (the Catholic Church)—but an insider who always, on some level, knew that the movement was wrong: at heart, he was always a renegade. ${ }^{4} \mathrm{He}$ thus 
is able to utilize the clout of first-hand experience as a Catholic cleric while distancing himself from worries about his past, in particular, the concerns held by anti-Catholic readers of trusting someone who had been a part of (in their view) an irrational, superficial, non-masculine, immoral, idolatrous, and deeply foreign religion. Chiniquy may have been a Catholic, but the text presents him as having always been, at heart, a Protestant.

\section{External Ethos via Printed Paratext}

There is rhetorical power in a renegade narrative; there is also risk. ${ }^{5}$ Although ex-priests were popular both in print (periodicals, pamphlets, books) and on the antiCatholic lecture circuit, there was rhetorical danger in basing the case against the Catholic community on the testimony of the excommunicated. In a 1915 pamphlet for the British Catholic Truth Society reviewing the character of ex-clerics who attacked the Catholic Church, G. Elliot Anstruther raises the issue of character and credibility concerning Chiniquy (and, indirectly, other ex-nuns and ex-priests): "a man does not remain associated for half a century with a communion which he afterward discovers to have been full of corruption, without laying himself open to the charge of either telling lies or having been singularly complacent of evil!" (5). ${ }^{6}$ Why should one believe—or trust - a defrocked priest? The paratext of Fifty Years begins to answer that question by constructing an ethos for Chiniquy as a renegade, but not a disreputable one: first, this renegade is a published Christian author, a devout Protestant, and a fervent patriot. I am arguing that these paratextual ethos constructions formulate Chiniquy as a renegade from the Catholic Church whose insider and conspiratorial tale can be believed-for an 
anti-Catholic audience, open to tales of Jesuit sophistry and nefarious Catholic schemes against the American dream, Chiniquy is a credible rebel with a divine and patriotic cause.

\section{Published Author}

Chiniquy, a national and international speaker, did not constrain his Catholic or Presbyterian ministry to the spoken word. He put pen to paper and created and then published his anti-Catholic and pro-Protestant polemic; in so doing, he followed a long Christian tradition. From the apostle Paul's epistles, to Augustine's Confessions, to Luther's 99 theses, to papal encyclicals or tweets, practitioners of the Christian faith have put their ideas to papyrus, parchment, paper, print, and pixel. As Candy Gunther Brown (2004) points out, "Christianity, like Judaism, has always been a text-centered religion that envisions God as the living and creative "Word"' (2). But Chiniquy was not only following in the footsteps of ancient apostles, saints, reformers, and priestshe was also following a well-worn path in nineteenth-century American religion, where

publication was the road to salvation. ${ }^{7}$ Evangelical Christians saw the printing press as a means to redeem, reclaim, renew, and revive individual souls and a nation. Publishing was viewed as a way to grow the church_- "a church-building strategy" (59). An 1863 Presbyterian committee warned, "with every other religious body in the land publishing its books and tracts, and sending them all over the West, in order to influence and control the minds of the people, it has become a question of life and death with us, as a denomination, to sustain this cause and publish our history, our polity, our doctrine" (qtd. in Brown 58-59). Brown adds that this warning demonstrates a prevalent view: 
"competitive failure in the print market spelled disaster in the religious marketplace as well" (59). The nineteenth-century American Christian church viewed the spreading of its message via print as a case of publish or perish, although in this case the perishing might be eternal in nature. Chiniquy thus followed in the millennia-old footsteps of Jewish and Christian writers while also taking advantage of the modern world's progress with — and through — the printed page.

With the printed word becoming more widely available to an increasingly literate society, the nineteenth century is, in fact, a story of the progress of print. ${ }^{8}$ Starting in the antebellum era and continuing through the Gilded Age, America's publishing industry—including its religious publishing—flourished. Paul C. Gutjahr (2007) argues that in the period from 1840 to 1880 , "the size of production and the scope of distribution made religious publishing one of the largest and most influential components in the nineteenth-century marketplace for print" (195). Carl F. Kaestle and Janice A. Radway (2009) describe America during the period from 1880-1940 as a "culture of print," in which "the printed word became the sine qua non of influence and organization" (8). It was an age characterized by "proliferating, ubiquitous, nearly inescapable print" (15). The publishing revolution was not lost on the Christian church, which took advantage of this as a means to spread the Word, nor was it lost on Chiniquy. In fact, the boom in publishing should be considered a factor in what led Chiniquy to both prominence and permanence. He wrote at a time when technological and structural changes transformed publication and distribution, positively affecting not only the availability of the book but also the availability of any printed materials. The anti-Catholic press, self-labeled as the "patriotic press," of the late Gilded Age through 
early twentieth century reaped the benefits of the revolution in periodical publishing, ${ }^{9}$ thus allowing them to widely disseminate the anti-Catholic Lincoln. Similarly, modern conspiracy theorists take advantage of the communication revolution that has come with the Internet, allowing them to spread easily, quickly, and cheaply their posturings. Chiniquy, tapped into the communication revolution of the age - as well as the cultural capital that comes with being an author.

Chiniquy is introduced to readers as not just the author of Fifty Years: as the title page indicates, he has authored multiple works, including The Manual of Temperance; The Priest, the Woman, and the Confessional; Papal Idolatry; and Rome and Education. ${ }^{10}$ As indicated by an "etc." at the end, the list is not comprehensive: Chiniquy has written even more. But together the works listed demonstrate that Fifty Years is not the work of a novice-Chiniquy is a prolific author. ${ }^{11}$ Together, these titles indicate a man who knows his subject well. He can write with expertise on a range of issues held dear by those who oppose Rome. With the exception of his temperance manual, all the titles fall within the anti-Catholic genre. But even with the manual, many would have associated the Catholic Church with alcoholism and abstinence with Protestantism: consider the memorable joining together of "rum" and "Romanism" in the nineteenth-century Republican insult against the Democrats as the party of "rum, Romanism, and rebellion [the Confederate cause]." The temperance guide would have aligned Chiniquy with Protestants - in spite of the fact that Chiniquy wrote and published his temperance manual while still a Catholic priest. ${ }^{12}$ The books themselves point to common anti-Catholic themes, including moral concerns (temperance), religious concerns (idolatry), socio-political concerns (education), and family and 
gender concerns: Chiniquy's anti-confessional book title is, tellingly, about the woman (mother, daughter, wife) — not the man —and the confessional. ${ }^{13}$ As a glance at the table of contents demonstrates, all of these themes show up repeatedly in the narrative, making the paratextual listing of other books by the author serve, in this case, as almost a précis for the book itself.

Publication is not an egalitarian endeavor among equals, but one concerned with power: "print was a key technology of power during this period [1880-1940]," state Kaestle and Radway, who point out how “[i]nterested parties to [print's] production and use struggled with each other over what could appear in print" (19). The status of a book's being published then can add stature to an author — he or she has made it past and been accepted by one of the institutional gatekeepers of print. Chiniquy's Fifty Years, though copyrighted by him, is not published by him; instead, he benefits in the reader's estimation by being associated with a printing house (in the case of the paratext that I am focusing on, Chicago's Adam Craig [1888]). ${ }^{14}$ As a variety of companies, both in the United States and abroad, published Fifty Years, the paratextual name of the publisher varies, with a partial list including Craig and Barlow (1885), Toronto's Willard Tract Depository (1888), London's Protestant Literature Depository (1886), and London's R. Banks (1888). Regardless of who published the book, Fifty Years bears the imprimatur of a publishing house and its corresponding status. Of course, not only does the fact of publication provide a certain level of respectability to a project, but also the status of the publisher itself can provide stature to its authors. In the case of Fifty Years, the most reputable publisher was the evangelical Fleming H. Revell Company, which published Fifty Years (1886), The Priest, the Woman, and the Confessional (1880), and 
the posthumous Forty Years in the Church of Christ (1900). Fleming H. Revell was brother-in-law to the Gilded Age's most popular evangelist, Dwight L. Moody, whose books and sermons Revell would publish. Beginning in the 1870s, the Revell Company would quickly become one of the most prominent American evangelical publishers. ${ }^{15}$ "Six Lies Nailed," a circa 1914 Catholic tract refuting six "moth-eaten calumnies" against the Church (including Chiniquy's Jesuit assassination of Lincoln story) took note of the relationship between Revell and Chiniquy: "Chiniquy was perhaps the most notorious of the ex-priests, his book, 'Fifty Years in the Church of Rome,' finding a respectable publisher in F. H. Revell \& Co., and going through some forty editions" (1). Though not explicitly, the tract's author, a near contemporary of Chiniquy, appears to connect the respectability of the publisher with at least part of the success of the publication. But success was not limited to any one publishing house, as the Craig edition's title page proudly proclaims in all caps, "FIFTEENTH EDITION." "16 Thus readers of this edition, from the very title page knew that they were reading a publishing success - and success in the American marketplace, secular or religious, is always a virtue. $^{17}$

The dedication in Fifty Years elucidates the power of the page - and thus the power of the author. To three different groups (members of the anti-Catholic Orangemen society, the people of the United States, and Roman Catholic members and ministers) Chiniquy issues the same command, "Read this book" $(3,4,6)$, promising that reading can both elucidate ("you will ... understand" [3, 4]) and illuminate ("you will see" $[3,6]) .{ }^{18}$ And the revelation it brings will save both the earthly nation and the 
eternal soul. An apathetic and unaware Protestant nation- "You are sleeping on a volcano, and you do not suspect it!" - must be awakened to the sleeper cell in its midst (3). Fortunately, it is not too late, and the means to their awakening rests in their hands, in the pages of Fifty Years. Read this book and "you will see that Rome is the sworn, the most implacable, the absolutely irreconcilable and deadly enemy of your schools, your institutions, your so dearly bought rights and liberties" (3). But reading will not only redeem the republic, it will also open heaven to those outside the Kingdom of God; and for Chiniquy, those outside the fold include Roman Catholics. However, "[b]y the mercy of God," through reading Fifty Years, they "will find in its pages" their escape from "lying traditions" (6). "Read this book," Chiniquy tells Catholics, "and, by the mercy of God, you will see the errors of your ways." And in so doing, not only will they leave a church, but they will also find the gift of eternal life and the salvation of their souls. A Protestant republic awakened and preserved. A Catholic people awakened and saved. And all because of a book.

In so presenting his book as a must-read, the text creates an ethos of power for Chiniquy, for though the salvation it promises comes as a result of God's mercy, it also comes as the result of his effort and experience. "Read it" (5), Chiniquy says to Protestant ministers, who have been seduced into sleep concerning the Jesuit fifth column — "modern Protestants have ... forgotten what Rome was, what she is, and what she will forever be: the most irreconcilable and powerful enemy of the Gospel of Christ" (4-5). "Read it," Chiniquy writes to Protestant ministers used to anti-Catholic tomes boring in nature (4), "and for the first time, you will see the inside life of Popery with the exactness of Photography" (5). As a photograph can with "exactness" represent 
a moment or scene in life, so Chiniquy's book will portray life as a Catholic accurately, with precision; Fifty Years will act as a hidden camera capturing that which the Church would prefer to be covered. "In this book," he tells his fellow Protestant pastors, "the sophisms and errors of Romanism are discussed and refuted with a clearness, simplicity and evidence which my twenty-five years of priesthood only could teach me."

\section{Devout Protestant}

For anti-Catholic readers, Chiniquy's prior Catholicism is his greatest asset (and his greatest weakness). The paratext foregrounds his former faith in a variety of ways, including the frontispiece showing a portrait of Chiniquy dressed as a priest holding a crucifix; the Catholic honorific "Father" on the title page; the title itself, "Fifty Years in the Church of Rome," stressing his expertise in a Roman (and not American) religion; and Chiniquy's own admission of his Catholic captivity: "There can be no boasting in me for having been so many years an abject slave of the Pope" (5). Chiniquy's Catholicism allows him to provide an insider's perspective, as one of the two Protestant ministers quoted in the dedication states, "It is the only book I know that gives anything like a full and authentic account of the inner workings of Popery on this continent" (4). But while it may provide an evidentiary advantage, Chiniquy's Catholicism also raises questions about the character of the eyewitness: is he really one of us? Can his conversion be trusted? Is he really Protestant? Or does he retain aspects of his Catholic past? For instance, how truly Protestant is a man who continues to use the Catholic title of "Father"? Is that not a violation of Jesus's command to "call no man your father" (Matthew 23:9)? Writing under the pseudonym, “An Indignant Protestant,” one 1869 
writer to the New York Evangelist refrains from giving Chiniquy the Catholic honorific. Though friendly to his cause, the indignant anonymous author refuses to call the expriest by such a title: "Mr. (I will not call him Father) Chiniquy" ("Romanism" 6) ${ }^{19} \mathrm{He}$ may have left them (the Catholics) but has he truly become one of us (Protestants)?

The paratext (as well as the actual text) negotiates this tension between Chiniquy's past and present in a variety of ways. It constructs a Chiniquy who can be trusted because while he once was lost (in Catholicism), he has now been found (in Protestantism). He is a true son of the Reformation - a modern-day Luther.

The double frontispiece ${ }^{20}$ provides visual evidence of Chiniquy's Catholic past and Protestant present. ${ }^{21}$ The first portrait shows an older Chiniquy, bearded, balding, graying, underneath which is his signature, bold and big, with a flourish: "C. Chiniquy." The second shows a much younger Chiniquy (in his mid thirties), dressed as a priest, crucifix in hand, bearing the title (in French) of "L'abbe" (the abbot)—“THE APOSTLE OF TEMPERANCE OF CANADA., ${ }^{22}$ This is Chiniquy the Catholic; however, even as a Catholic he was Canada's apostle of temperance, a cause held dear by many of his Protestant readers. Separated by decades, the pictures—old/young, Protestant/Catholic, preacher/priest—frame the dividing points of his life, physically, religiously, and vocationally. The days of wearing robes have been replaced by a man's coat and an elderly man's beard. Chiniquy's Catholicism, though not to be classified as a young man's indiscretion, was a part of his younger days, long past; it is his Protestant picture that he signs.

The dedication to the Orangemen society signals Chiniquy's Protestant stance. The Orangemen take their name from the Dutch and Protestant prince of Orange, 
William III, who deposed the last Catholic monarch of England, James II. According to Ryan O'Connor (2006), the Orange Order had its start as a "paramilitary organization" during the late 1700s, "spread[ing] throughout much of the English-speaking world," with "Orange lodges . . located across Ireland, England, and the British colonies" (74). As was true in the United States, nineteenth-century Canada experienced a significant influx of Irish immigrants, with many being Protestant (74-75). In this context, "British North America," according to O'Connor, "proved conducive to the growth of Orangeism" (74). The core beliefs of the Orangemen centered on "a loyalty to the British Crown and Protestantism" (75). By the mid-century point, the Canadian Orangemen had become, according to Brian Clarke, "a mainstream association devoted to maintaining Protestant hegemony in the United Canadas [the province resulting from the union of Canada East and Canada West] and upholding the colony's British character" (qtd. in O'Connor 75). They were a politically significant lobby, with (by 1864) "an estimated 200,000 members" across Canada. Of course, their political impact varied by location; but in Toronto, they were a stronghold: "twenty-one of twenty-four mayors ... between 1845 and 1900 were members.” Chiniquy identifies himself with the Orangemen, calling himself "the humblest of their brethren" (3). But Chiniquy not only claims to be one with them, he is also claimed by them to be one of them. A brief note from John Hamilton, secretary of a Montreal area lodge, confirms "that Bro. C. Chiniquy ... is a member in good standing." As Chiniquy pleads against the white and yellow colors of the Vatican flag, he could wrap himself up in Orange. ${ }^{23}$

The dedication to Protestant ministers aligns Chiniquy with "[f]aithful" Protestantism $(4,5)$. The adjective here is key, for it speaks to Chiniquy's diatribe not 
only against Catholicism but also a Protestantism that he deems not worthy of the name. He laments the loss of genuine Protestantism: "ignorance" of the true nature of Catholicism "paralyzes the arm of the Church of Christ, and makes the glorious word 'Protestant' . . almost a dead and ridiculous word" (4). In a sense then, Fifty Years is both anti-Catholic and anti-Protestant, for not every Protestant in name is a Protestant in deed. There are Protestants, and then there are faithful Protestants, who understand Rome and what is at stake concerning both the Christian faith and the American nation. ${ }^{24}$ Later, in the main text of the book, Chiniquy will condemn those who send their children to parochial schools as being "false" to the Gospel and "a man of no religion" (88). ${ }^{25}$ Chiniquy thus draws a line not only between Protestants and Catholics but also between faithful Protestants such as himself, and those who have the name but not the spirit. He asks "who really does protest against Rome, to-day?" (6). If others are ignorant, he is informed; if others are apathetic; he is zealous.

\section{American Patriot}

Chiniquy may travel the globe to spread the gospel of anti-Jesuitism, but he retains a special place in his work for the people of the United States. ${ }^{26}$ He may be a citizen of the world, but he remains a prophet and a patriot for the United States republic. And so he dedicates the book to the "HONEST AND LIBERTY-LOVING PEOPLE OF THE UNITED STATES” (3). As he will also do in his words to Protestant ministers, Chiniquy seeks to enlighten American citizens to the demonic serpent in their new world Eden: "you are pressing on your bosom a viper which will bite you to death, and you do not know it." In this book, he will not only reveal the treason against the 
present that the Jesuits seek to perpetuate - they "are the enemies of your schools, your institutions, your so dearly bought rights and liberties"- but also their treachery in the past, in particular, their responsibility for the war between brothers and the murder of the redeemer president. "[I]t is to Rome," writes Chiniquy, "you owe the rivers of blood and the unspeakable horrors of the last civil war" (4), with the national tragedy culminating in the final, priestly sacrifice: "Abraham Lincoln was murdered by Rome." Americans, thus, must be constantly vigilant to the Guy Fawkes in their midst: "you will learn to be more than ever watchful in guarding the precious Treasures of freedom bestowed upon you by your fathers.” Interestingly, perhaps Chiniquy’s stated concern for the American republic and its freedoms lines up with some contemporary research on conspiracy theory believers which suggests that conspiracy believers have both "higher political cynicism" and "greater support for democratic principles" (Swami et al. 445$){ }^{27}$

Chiniquy demonstrates his patriotic mission not only in his message of caution for a liberty-loving nation but also in words of appreciation for an American soldier. The immigrant priest opens his series of dedications with words of gratitude to Colonel Edwin A. Sherman, a veteran of both America's war with Mexico and its war with itself. ${ }^{28}$ According to a 1944 biography by his grandson (Allan B. Sherman), Edwin A. Sherman was a journalist with the abolitionist Emancipator and Free American before joining the United States Army and serving in the Mexican War (259), as well as serving the Union cause during the Civil War ("major of engineers" and a California National Guard instructor [260]). ${ }^{29}$ Chiniquy dedicates Fifty Years to Sherman as the 
"first among the many"; in fact, Sherman is the only individual Chiniquy singles out for a specific dedication. The postbellum age was a time during which both North and South memorialized the fallen soldier. Democrats accused Republicans of always waving "the bloody shirt" of their Union dead in order to win at the ballots. ${ }^{30}$ Offering tribute, then, to a soldier and Union officer, would tap into powerful warrants in postbellum rhetoric.

Chiniquy's stated reason for making Sherman his head dedication, "first among the many," concerns Sherman's help with tracking down the alleged Jesuit killers of Lincoln: "I owe this to you as a token of gratitude in my researches after the true murderers of our martyred President Abraham Lincoln" (3). Published shortly before Chiniquy's 1885 Fifty Years, Sherman's 1883 The Engineer Corps of Hell; Or Rome's Sappers and Miners devotes its second section to demonstrating that the Catholic Church was behind the assassination of Lincoln. ${ }^{31}$ At Lincoln's funeral procession in New York City, Sherman was told by a fellow marshal, "The South had nothing to do with the assassination of Abraham Lincoln, but he was the victim of a Jesuit plot" (129). Sherman spends the next eighteen years searching for the truth, the results of which he claims, "satisfactorily prove[ ] . . that Abraham Lincoln fell the victim of the Papal power." And one of the main witnesses he calls upon is Charles Chiniquy and the soon-to-be published Fifty Years in the Church of Rome, of which Sherman includes two chapters (chapters 42 and 54).

An additional reason for Sherman's placement at the head of the list may concern a potentially eager audience for Chiniquy's story. Sherman was a high-ranking Mason $\left(33^{\circ}\right)$ in California, ${ }^{32}$ authoring several works on Masonry. ${ }^{33}$ And what makes 
Sherman's lodge membership significant for readers of Fifty Years is the problematic relationship between Freemasonry and the Catholic Church. At times, twentieth- and twenty-first-century conspiracy theorists lump Catholics and Masons together, "asserting that Jesuits and Masons work together for common, diabolical ends" (Barkun 132). In truth, their past and present relationship is antagonistic, a problem conspiracists resolve by explaining that seeming hostility between groups, which are actually in league with each other, is feigned in order cover up secret alliances (Barkun 132-33). ${ }^{34}$ Historically, the Church prohibited members from becoming Masons. ${ }^{35}$ A 1983 statement from the Vatican's Office of the Sacred Congregation for the Doctrine of the Faith Masonry (headed by then Cardinal Ratzinger, who would become Pope Benedict XVI) reiterated the anathema on Catholic Masonic membership, declaring that Masonic "principles have always been considered irreconcilable with the doctrine of the Church and therefore membership in them remains forbidden. The faithful who enrol [sic] in Masonic associations are in a state of grave sin and may not receive Holy Communion. ${ }^{36}$ Masons, too, at times placed themselves in opposition to Rome. The title page of Sherman's Engineer Corps of Hell (whose title page lists prominently Sherman's own Masonic credentials), describes the book as containing "MATTER INTENSELY INTERESTING, ESPECIALLY TO THE FREEMASONS. ${ }^{\text {37 }}$ Sherman goes on to describe the the Catholic Church as keeper of evil secrets, an opponent of free speech, and the persecutor of Masons. ${ }^{38}$

In the Robert Banks and Son (London) and William Briggs (Toronto) edition, Chiniquy dedicates the work not only to Sherman, but also to all Free Masons in the United States and around the world ("Dedication to the American Edition"). ${ }^{39}$ Although 
he denies being a Mason "apologist," Chiniquy defends their secretive nature, arguing for the necessity of secrecy in a variety of groups (armies, merchants, governments, etc.), even pointing out that "Christ Himself kept His own secrets well" (iii). Chiniquy praises Masonic bravery, pointing to the Italian unification wars under Giuseppe Garibaldi, a Mason. ${ }^{40} 41$

Thus, while not inherently Protestant or anti-Catholic, Masons were a demographic from which Chiniquy might find support for his attacks on Rome- - hence, the usefulness of acknowledging a high-ranking Mason. That at least Sherman saw the importance of Chiniquy's message can be seen in that he dedicates Engineer Corps of Hell to his co-detective, calling him "the Martin Luther of America, the Client and Friend of Abraham Lincoln (3). And as the paratext reveals, Chiniquy was the friend not only of Lincoln and Sherman, but also of every liberty-loving American.

\section{Internal Ethos Via Autobiographical Contstructs}

Having examined Chiniquy's extratextual or external ethos via the paratext, I now consider his ethos as constructed within the text—his intratextual or "internal" ethos. I begin by briefly examining Fifty Years via Creps's ethos categories for conspiracy advocates (those who believe that a conspiracy exists). Creps argues that "conspiracy advocacy may involve certain consistent patterns of speaker ethos" (210). Using two primary examples-Woodrow Wilson's attorney general Mitchell Palmer's conspiratorial argument concerning communism and Rush to Judgment author Mark Lane's revisionist history of the JFK assassination — Creps suggests a three-fold prism for understanding how conspiracy proponents typically position themselves. First, the 
unveilers of hidden plots "adopt the position of crusader," making them "leader[s] of 'the people," whose "efforts are the only thing that stand between the community and disaster" (208). Second, "conspiracy advocates" position themselves as those with "superior knowledge or abilities." Third, conspiracy believers make allegations of having been the victims of persecution. Fifty Years confirms Creps's conspiracy ethos template, for Chiniquy connects to his audience via each of these three roles. However, my reading expands Creps's work, adding two other significant ethos constructions. First, Fifty Years positions Chiniquy as a visionary, as someone who hears the voice of God and, eventually, sees the Son of God. Chiniquy describes a "mysterious" voice that helps his Catholic self see the errors of the Roman way. This move enables him to call on the ultimate witness for his Christian audience - God. Second, Fifty Years positions Chiniquy as an insider within the conspiratorial institution (the Catholic Church) — but an insider who always, on some level, knew that the movement was wrong: at heart, he was always a renegade. He thus is able to use the clout of eyewitness testimony while distancing himself from potential anti-Catholic concerns about his past: Chiniquy may have been a priest, but at heart he was always a Protestant.

This chapter, then, sets forth a useful template for examining ethos construction not only in renegade rhetoric but also in conspiracy argument. Chiniquy's ethos construction provides a means by which to understand how ex-clerics, with their conspiracy charges, attempted to develop trust between themselves and their readers. This is significant especially in light of how historically important the anti-Catholic and nativist movements were in the history of the United States and the prominent role played by these rebels with a divine cause. Chiniquy's fivefold ethos construction also 
provides a template with which to think through ethos in other types of conspiracy argument. In describing this construction as a template, I am not suggesting that it can be generalized as universally applicable to all conspiracy narratives. Both Creps's case studies and my own are rooted in particular historical and cultural moments. Additionally, they examine specific literary genres. Chiniquy's Fifty Years, for instance, is an autobiography and a Christian conversion narrative written to a Christian audience who would accept several underlying premises, such as the direct working of God in human lives, including (in some fashion) God's leading people to himself. ${ }^{42}$ This template does serve as a heuristic, a means by which to think through how ethos works in a variety of conspiracy narratives. It is my contention that ethos, even more so than logos in some texts, does much of the hard work of persuasion. It certainly did with renegade rhetoric, and I would contend that it continues to do so in many contemporary conspiracy theories. Although the parallels between a nineteenth-century ex-priest's autobiographical experiences and that of a twenty-first-century UFO abductee's repressed memory are not exact, there are points in common, including the need to establish a trustworthy ethos for allegations that cannot be categorically proven or disproven. ${ }^{43}$ It is here (to again take note of Aristotle's argument), "in cases where there is not exact knowledge but room for doubt," that ethos proves itself both most needed and most persuasive.

\section{The Ethos of a Robed Crusader}

Creps describes a "posture of a crusader" in both of his case studies: Attorney General Palmer (1919-1921) positioned himself as "leading his Department in a 
desperate battle against the powerful forces of international Bolshevism," and JFK conspiracy theorist Mark Lane "pos[ed] as a self-appointed Special Prosecutor trying to unearth the real facts of the Kennedy assassination so that the secret powers who oppose 'truth,' 'justice,' and the 'rule of law' will be vanquished" (208). Together, Palmer and Lane illustrate a crusader ethos, in which the speaker/author "is a leader of 'the people," whose "efforts are the only thing that stand between the community and disaster."

Fifty Years situates Chiniquy in the role of a maverick opponent to institutional, societal, religious, and personal corruption: he is a crusader engaged in holy war against an unholy church. He campaigns against simony, the confessional, priestly celibacy, and other Roman Catholic dogmas, (typically) positioning himself as one against many. And the stakes are never higher, for Chiniquy fights an institution that is a "permanent political conspiracy against all the most sacred rights of man and the most holy laws of God" (4). Chiniquy clearly sees his work as having profound significance in this near apocalyptic battle. With the conversion to Protestantism of a few thousand French Canadian immigrants in his last Catholic parish in northern Illinois, he sees "only the beginning of the most remarkable religious reform which had ever occurred on this continent of America" (801). Although he acknowledges a sense of "unworthiness" and "defienc[y]" for the work he sees God giving him $(801,802)$, he still places himself on level with the "giants" of the Protestant Reformation: "The terrible difficulties which Luther, Calvin and Knox had met ... were to meet me" (802). Of course, by connecting him to the founders of the Protestant movement, the text taps into their ethos (something it will also do with Lincoln): he is leading a reformation in North America 
that will parallel Luther and Calvin's in Europe. As such, he is worthy of the same level of respect and trust they received. But establishing himself as a maverick reformer on the level of a Knox also serves as an attack on the ethos of the Catholic Church, for it reminds his anti-Catholic readers of their origin story, one in which a few, brave men led the charge against a corrupt and anti-Christian church. It remains a church in desperate need of a new generation of reformers - a mantle the text places on Chiniquy's shoulders.

\section{The Ethos of Victim}

Throughout Fifty Years, Chiniquy presents himself as the object of ecclesiastical hostility - an opposition that begins in his youth with the purported theft of his recently widowed mother's only cow by the local cleric, through opposition to his temperance movement by intemperate peers, to his trial by a parishioner (supported by Chiniquy’s superiors), and culminating in his excommunication by a treacherous bishop. In

portraying himself as the target of persecution by Catholic leaders, Chiniquy takes on Creps's third ethos category for the exponent of conspiracy, that of "the persecuted rhetor" (209). Attorney General Palmer, according to Creps, asserts "that his Department's activities have been carried out in spite of Congress rather than with their assistance," "list[ing] numerous complaints against the legislature and thus plac[ing] himself in the role of a valiant (and ultimately victorious) underdog." JFK revisionist Lane (Creps's second case study) makes a more explicit persecution argument: Lane “details several examples of government surveillance of his activities, relates attempts 
by the Bar to have him sanctioned, and speaks of efforts to have him prosecuted and harassed in other ways" (209-10).

There are benefits in portraying oneself as the victim of persecution. Creps argues that such positioning might "confirm that a powerful foe does exist that thinks he or she is so dangerous to the Plot as to merit overt suppression" (210). In addition to elevating the status of the revealer of the plot_-'I'm so important that they are out to get me"- persecution attacks the ethos of the conspirators: they are a malignant, malevolent, oppressive force. In Chiniquy's charge, the Catholic Church reveals itself not to be a Christian institution but a violent oppressor of Christian people and values. For instance, if other churches encouraged Bible reading, the Catholic Church violently discourages it. Chiniquy relates the visit to his childhood home by the local priest, who proceeds to demand that his father surrender the family Bible so that the priest may burn it (12). The father refuses, and young Chiniquy, who has already proven himself an adept reader of Scripture, rejoices in the victory of his biological father. Chiniquy's father, however, dies while Chiniquy is still a young man. Within days of his father's death, the same priest visits the grieving widow, left nearly destitute to raise three children. But rather than comforting her, the priest (in Chiniquy's telling) extorts her, demanding the family's only cow as payment for masses to be offered for her husband's soul, now enduring "the flames of purgatory" (44). Chiniquy concludes the chapter with a prayer for justice, asking, "How long, shall ... the Church of Rome, be permitted to fatten herself upon the tears of the widow and the orphan by means of that impious invention of paganism — purgatory?" (48). In so portraying the Catholic clergy as persecutor Chiniquy taps into Christianity's complex history_one often stained with 
blood. But Fifty Years is no objective retelling; it includes only Catholic transgressions. Chiniquy utilizes Catholic violence against himself to remind readers of past Catholic violence, and by taking on the role of the persecuted one, Chiniquy can claim that the Church which forced Galileo to recant and slaughtered the Huguenots on St. Bartholomew's Day is not the Church of a distant past—it is the Church of the present. Echoing a common anti-Catholic trope, the Church does not change: once a persecutor, always a persecutor. Or as ex-priest Slattery states, "If Rome had the same power to-day that she had in times past, she would be the same old persecuting tyrant" (viii).

Even when he leaves the Church, its persecution does not end, which would be a key point for his Protestant readers—-the Church oppress Protestants, too. ${ }^{44}$ Gilded Age anti-Catholic polemicists would describe a ranged of purported crimes against Protestants, from alleged Catholic nepotism toward government jobs (Catholic control of the Post Office, for instance) to charges that Catholics were going to initiate a holy war against American Protestants in the fall of $1893 .{ }^{45}$ Chiniquy ends Fifty Years by cataloging the violence of which he had been a frequent target, a litany that includes specious lawsuits, libelous rumors, flying stones and bullets, plunging daggers, and riotous crowds calling out "Kill him! Kill him!" (825): "not less than thirty public attempts have been made to kill me" (823). Chiniquy is not the only target; victims abound in Fifty Years: women are the victims of lecherous priests, nations are the victims of Catholic anti-intellectualism, and if the United States ignores the enemy on its shores then it will eventually become the victim of Vatican intrigues.

An Expert Ethos 
Fenster describes the importance of interpretive skill for the hero of a conspiracy narrative: it is a pivotal moment for when "the central character, through investigative skill or by sheer luck, uncovers evidence of a conspiracy" (124). "This discovery . . ," he argues, "transform[s] how the character perceives the world. ..." and "initiates nothing less than a totalizing conversion." But key to this worldview transformation is the ability to secure and analyze evidence: "The protagonist collects, sorts, and interprets information" (125). Fictional conspiracy narratives highlight this need for superior knowledge skills by casting their "central characters" as "professionals in some kind of knowledge industry." And so Allan Pakula's The Parallax View features Joe Frady (played by Warren Beatty) as a reporter, or Oliver Stone's JFK (1991) revolves around the work of real-life Jim Garrison, a district attorney. To effectively reveal the workings and trappings of a conspiracy a person must demonstrate genuine expertise in his or her ability to interpret and create knowledge, for "the conspiracy narrative foregrounds the cognitive act of interpretation" (126). This emphasis on interpretive skill is in keeping with Creps's description of the ethos of an expert, which he describes as a "claim to superior knowledge or abilities" (208, emphasis his). For Creps, the expert stance is seen in Attorney General Palmer's positioning of himself as "head of a powerful investigative agency," who "speaks of the "confidential' information" that guides his prosecuting Communists, and Lane, the revisionist historian, "implies his expert credentials with the use of terminology, the mastery of vast amounts of highly specialized evidence," and moves by which he distances himself and his work from (in Lane's words) “amateur investigators." In positioning themselves as experts, conspiracy 
believers "increase the salience of their interpretation" (209). They see what we are blind to, but will see, if we open our eyes to their expert vision.

Fifty Years presents Chiniquy as a bit of a polymath; his rhetoric may stem from the Reformation but he himself is a Renaissance man: a multi-lingual, well-read, selftaught orator with lawyer-like analytical and prosecutorial skills. For Fifty Years's target audience, however, it is essential that Chiniquy demonstrate an expertise in Catholicism, which he does both by means of education (he pores over Scripture and the works of the Church Fathers) and experience (his life as a Catholic priest). Father Chiniquy is a man of books and one book in particular - the Bible. His passion for Scripture can be seen during a holiday break from his seminary studies. Chiniquy stays behind at the school, secludes himself in the library, and focuses his attention—and affection—on one volume in particular: "Among the forbidden books ... I found a splendid Bible.... I lifted it to my lips, and kissed it. . . I pressed it against my heart" (82). ${ }^{46}$ The maturing Chiniquy will study the church fathers, but he primarily devotes himself to Bible reading. His expertise as an anti-Catholic, however, is not primarily found in his literacy and analytical skills: his primary authority comes from his fifty years in the Catholic Church. Indeed, although Fifty Years contains multiple quotations from biblical and Church sources, the grounds of many of his arguments - and the focus of the book's overall narrative - are far more experientially than textually based. As an example, consider his assault on priestly celibacy. Although he relates a classroom discussion with his principal over several Scriptural texts (ch. 14, "The Vow of Celibacy"), his attack also draws on his own experience with what celibacy drives men to do in - or out of - the confessional. Fifty Years practically opens (ch. 2) with the tale 
of a castrated cleric. While playing with friends near a monk's home, a young Chiniquy "saw something covered with blood thrown from the window" (18). The monk-turnedsurgeon "had ceased to be a man" (19). Chiniquy uses this self-mutilation as an argument against celibacy: "the cries of desolation I heard that day, were but the echo of the cries of desolation which go out from every nunnery, every parsonage and every house where human beings are bound by the ties of Romish celibacy" (21).

Whether he bases his arguments on Scripture, the Fathers, or personal experience, the text presents Chiniquy as the expert interpreter (a typical move in conspiracy rhetoric); he is the one who knows how all the pieces fit together to form a cohesive picture. And so something as seemingly benign as a smiling Sister reveals something far more sinister. Chiniquy knows why the caged nun sings: to deceive foolish Protestant parents into enrolling their children in Catholic schools. The "angelic smiles" of the nuns are in fact "Cruel deceptions!" (90). And how does he know? "I read with my own eyes, in a book of the secret rules of the convent, that one of their rules is always, especially in the presence of strangers, to have an appearance of joy and happiness, even when the soul is overwhelmed" (91). But lest readers think that Chiniquy's knowledge only comes from a "secret" rules book, he points again to himself as the arbiter of knowledge: "Ah! if Protestants could know, as I do, how much the hearts of those nuns bleed." It is this educated, experienced, interpretive expertise that Chiniquy will utilize in his conspiratorial Lincoln narrative, in which he acts not only as expert prosecutor — the Catholics did it! — but also as expert witness — Lincoln told me so! 


\section{The Ethos of Visionary}

Chiniquy's journey from priest to preacher comes about through his education and experience, but his conversion does not come through human abilities or actions alone-Fifty Years portrays him as divinely led to leave the Catholic Church. Through frequent voices and occasional (but narratively significant) visions, Heaven itself is portrayed as guiding Chiniquy to "Come out of Babylon" (483). This heavenly communication helps construct a powerful ethos for a Christian audience: Chiniquy is in touch with the divine. And for the charges he makes, charges not easy to prove, Chiniquy can call on the ultimate witness-God himself.

Early on, the autobiography depicts Chiniquy as hearing voices. Sometimes these voices are his own internal monologue or sense of self, which he describes as his "private judgment" (433) or "the voice of my conscience," which can "thunder[ ] . . like the voice of a thousand Niagaras (474). At times he labels them "the voice of my intelligence" (366), while in other places he aligns them with rationality—-they are "the voice of my reason" (437), which a priest striving to make the young Chiniquy submit to the "voice of the Church" (138) attempts to undermine as the "voice of your own deceitful reason. ${ }^{, 47}$ These expressions serve a useful rhetorical purpose in that they place conscience, reason, and intelligence in opposition to Catholicism: reasonable and intelligent people who follow their conscience will reject the Vatican. ${ }^{48}$

Whether the voices are internal/psychological or figurative, they unite as a loud, persistent chorus of opposition to Catholic dogma and priestly behavior. For instance, a "secret voice" that "arose within" him addresses Chiniquy (in King James English) about the sacrament of confession: "Understandest thou not that the Spirit of God ... 
produces effectually in the hearts and minds of these Protestants a work much more durable than thy auricular confession?" (302). On another occasion, after vermin have devoured a blind priest's communion wafer, Chiniquy's "intelligence" says "with a thundering voice" to him concerning transubstantiation, "Do not remain any longer the priest of a God ... whom the rats can eat" (366). After a confrontation with a hypocritical bishop who has taken a temperance pledge in public, only to drink in private, "a voice" asks Chiniquy to ponder the impiety of his fellow priests: "Do you not see that the bishops and priests . . do not believe a word of their religion?" (503). ${ }^{49}$ Although the next morning finds Chiniquy sick, the Janus-faced bishop is in even worse condition: a carousing cleric from the night before has absconded with both a parishioner's wife and the bishop's money $(\$ 4,000)$. God has punished the sinful prelate and, in the process, proven the voice to be true.

Even though these voices are portrayed as Chiniquy's own intelligence, reason, and private judgment, the text presents them as also being providentially used by God; along with life experiences and the voice of Scripture (through which Jesus speaks [457]), the secret speeches are seen as a part of God's directing Chiniquy to leave the Church. These guiding voices perhaps reflect the Calvinistic doctrine of divine election in which one does not save oneself; instead, God controls the process and calls sinners to salvation. As a committed Presbyterian (at the time of the writing), Chiniquy sees a divine providence at work throughout and in all aspects of his life: "God controls the greatest as well as the smallest of the events of this world" (268); in another place, he speaks of "the mysterious ways through which God leads his elect" (316). In addition to the divine leading through his conscience, there are places in the text where the voice 
seems distinct from Chiniquy's intelligence. Although the message is the same--there's no significant change in style or content- the speaker appears to be different. At times, the voice Chiniquy hears seems to be presented as the actual voice of God.

Chiniquy writes of a "mysterious" voice that speaks to him. The first instance takes place when an older priest argues that the Catholic Church must be of God because it has, somehow, survived a long history of hierarchical immoralities- "the horrible, unmentionable crimes of so many ... Popes" (194). While listening, Chiniquy hears a "mysterious voice" quoting Scripture and subverting the argument: "A good tree cannot bring forth evil fruit." As Fifty Years continues, the voice does not limit itself to citing Scripture. Chiniquy attends a party where another priest jests irreverently concerning the sacrament of communion. Here the mysterious voice also questions-in language a devout Catholic would find offensive if not blasphemous - the doctrine of transubstantiation, asking him, "Are you not a fool to believe that you can make a God with a wafer[?]" (267). Chiniquy attempts "to stifle" the voice; however, he only partially and temporarily succeeds.

Who is the mysterious speaker? Chiniquy the narrator of his life story knows; but Chiniquy the character in the autobiography is uncertain. This uncertainty exists even after God has explicitly identified himself. Earlier in the story, Chiniquy finds himself questioning Catholic doctrine concerning the Virgin Mary (Mariology). During a dark night of the soul, he wrestles with his faith—and with the voice, by which he is so "bewildered and confounded" that he "thought it was the devil's voice" (475). Chiniquy cries out to God, "Save me from my enemy’s [Satan] hand!” To this plea comes a reply: "It is not Satan's voice. It is I, thy Savior and thy God, who speaks to 
thee." The voice of God, in good Protestant fashion, directs Chiniquy to the pages of Scripture. In spite of this divine identification, he continues to question the source of the mysterious speech until the night of his conversion, when Chiniquy the character finally acknowledges "that the voice which had so often troubled and shaken my faith, was the voice of my merciful God" (791).

While voices are more frequent, visions play a significant role in his two most important life vocations: Chiniquy becomes a temperance priest and a Protestant preacher because of divine visions. In the same chapter where he is introduced to his mentor in the temperance movement (Protestant physician Dr. Douglas), Chiniquy describes in macabre detail the death of a Catholic mother and daughter due to the mother's alcoholism (while drunk, the unnamed mother accidentally kills her young daughter). ${ }^{50}$ After the daughter's death, the husband requests Chiniquy to comfort his distraught wife. But overcome with grief, the mother confesses the wickedness of wine, calls on Chiniquy to preach temperance, and dies (279). ${ }^{51}$ After this, Chiniquy has a near-beatific vision of his own mother. Whether awake or asleep he is not certain, but he sees her "standing by me, holding by the hand the late murderess, still covered with the blood of her child." As the child's mother while still living had charged him, now, too, his own deceased mother commissions him — with similar language - to canvas Canada for temperance, commanding him to "give up forever the use of those detestable beverages, which are cursed in hell, in heaven and on earth" (280). Chiniquy questions the reality of the vision; perhaps he is suffering a post-traumatic reaction. ${ }^{52}$ He weeps and prays, "Do the voices I have just heard come from thee? Hast thou really sent one 
of the angels of thy mercy, under the form of my beloved mother? or is all this nothing but the vain dreams of my distressed mind? (281). As he prays to know God's will, "the answer"—which comes in the language of Scripture (Matthew 10:27)—“was suggested" to him: "What I have taught thee in secret, go and tell it on the housetop!" Chiniquy takes the pledge and becomes a temperance campaigner. He will heed his holy mother's call and the heavenly voice.

If the vision of his mother drives him to temperance, then the presence of his Savior brings to him his salvation. In the sixty-fifth of sixty-seven chapters, Chiniquy finally leaves Roman Catholicism for Protestantism. Already the subject of church discipline, including possible excommunication for his unwillingness to submit to a bishop's authority, Chiniquy wrestles with the "awful, undeniable truth" that "My church was the deadly, the irreconcilable enemy of the Word of God" (791). He prays, "I have given up Rome! But, O Lord, where is thy church? Oh speak!! where must I go to be saved?" Hearing no answer, he feels "forsaken" by God. ${ }^{53}$ Alone in a hotel room, he momentarily takes a knife to his throat. But with the knife fallen to the ground, he prays for help and then recalls that he has his New Testament with him. ${ }^{54}$ He opens the Bible "at random," and finds an immediate peace. The relief, however, is shortly replaced by a darkness that becomes "before my mind. . . . a very high mountain ... of my sins" (794), under which he "felt crushed . . f for it was as heavy as granite. I could scarcely breathe!" ${ }^{55}$ But "after eight or ten minutes of unspeakable agony, the rays of a new and beautiful light began to pierce through the dark cloud. . . . In that light, I clearly saw my Savior" (795). Jesus appears, "covered with blood, the crown of thorns was on his head and the nails in his hands." And Jesus speaks: "I have heard the cries, I 
have seen thy tears, I come to offer myself to thee as a GIFT ${ }^{56}$ I offer thee my blood and my bruised body as a GIFT to pay thy debt; wilt thou give me thy heart? Wilt thou take my Word for the only lamp of thy feet and the only light of thy path? I bring thee eternal life as a gift." The Jesus of Chiniquy's vision sounds like an evangelical.

Protestants, for instance, contrasted Catholic soteriology (the doctrine of salvation) with their own as being a matter of grace versus works. In his vision, Jesus aligns himself with Protestants by stressing that salvation is a gracious "gift," using the word three times, with Chiniquy placing it in all capitals twice. Additionally, the Jesus of the vision commends the Protestant doctrine of sola scriptura by asking Chiniquy to "take my Word ... only" (and not Church councils, the works of Church Fathers, or the current Church hierarchy) for his guide. Chiniquy accepts, and with renewed courage to stand against the "Popes, ... bishops and priests, and millions of abject slaves," hesomewhat anti-climactically_ - washed my tears, paid my bill and took the train" to return to his parishioners to "tell them what the Lord has done to save my soul."

Although visions play a significant role in the defining movements of his life, temperance and Protestantism, Chiniquy does not accept the validity of all visionseven his own. In 1837, after contracting typhoid, at the point of death Chiniquy experiences "a terrible vision" in which he sees the divine scales of justice (320). ${ }^{57}$ Feeling too sinful to plead to God, he turns to the saints: St. Anne and St. Philomene, who appear and declare that he will be cured. Chiniquy is healed. But though Catholics believe his healing to be supernatural, Chiniquy's Protestant doctors "protested against that view in the name of science and common sense" (324). Here again, Chiniquy aligns Protestantism with science (and reason) and Catholicism with superstition. Catholicism 
is for a prescientific age, while Protestantism is for the modern world — another typical anti-Catholic rhetorical move. Chiniquy embodies the protests of his Protestant physicians in a catechism-like question/answer interview with his temperance mentor, Dr. Douglas. Over the course of a stilted bedside dialogue, Douglas demonstrates to Chiniquy — and Chiniquy's readers - that dreams and cures such as these are not supernatural visions or healings; rather, they are the product of the sickly mind and the powerful, but nonetheless human, will. ${ }^{58}$

Given the narrative weight attached to his temperance and conversion visions, along with the near constant supply of divine communication via mysterious voices, Chiniquy's lengthy refutation of Catholic visions as the product of a sickly (and superstitious) mind is particularly striking. Chiniquy shows little self-awareness that by calling into question the validity of Catholic visions he raises questions concerning his own. Indeed, there is no explicit effort by the author to distinguish how one is valid while the other is false. Perhaps for Chiniquy the distinction comes down to doctrine: if a vision supports Protestantism, it is true; if a vision supports Catholicism, it seems to be false.

Neither the voices nor the visions are overtly conspiratorial in tone or content, and yet both support Chiniquy's ethos and thus the acceptability of his conspiracy narrative. The visions and voices do not, for instance, allege Jesuit plots, nor do they have a significant presence in that portion of the autobiography dealing explicitly with the Lincoln conspiracy plot—-the voices and visions guide Chiniquy out of Catholicism, but they do not lead him to Lincoln's true killers. However, while not inherently 
conspiratorial, the supernatural communications establish a visionary ethos for Chiniquy, helping to connect him to both a Protestant and a Catholic audience.

To some extent, the visions and voices level the miraculous playing field. As a Protestant he derides any and all Catholic miracles — even those in which he once participated (his vision of the two saints). However, if Catholic saints hear divine voices and have divine visions, so, too, does Chiniquy. Like the saints, Chiniquy has heard the voice of God; he has been commissioned on a holy quest by a heavenly (his departed) mother; and he has had an ecstatic experience of the Lord himself. If St. Paul fell off his horse at the voice of the Savior, Chiniquy had a mountain of sin removed by the Master's hand.

Additionally, the voices speak to Catholic concerns and questions about the validity of Protestant authority. If Protestantism, with its doctrines of the priesthood of all believers and sola scriptura, takes the authority for interpreting Scripture from the church collective and places it in the hands of the individual, then won't that result in a continual dividing of Christendom as people interpret Scripture differently, according to their own understandings? And how will people know that theirs is the correct interpretation? Should Chiniquy leave Catholicism would he "not find still more damnable errors among those hundreds of Protestant churches, which ... are divided and subdivided into scores of contemptible sects...?” (483). Eventually, while working in his garden, he sees the answer in Jesus's parable of the Vine and the Branches (John 15:1-8). Branches may differ significantly, but as long as they remain attached to the vine, "they all gave ... excellent fruit." Likewise, churches may differ considerably, but as long as they are connected to Christ, they are acceptable. Chiniquy comes to this 
interpretation, though, not as the result of a day's work in his garden, nor as the product solely of diligent Bible study. Jesus himself works in such a way as to help him understand Scripture: "my dear Savior would make me understand his sublime words." Chiniquy's experience with the voices in general, then, illustrates how the Protestant doctrine of a person using individual conscience and reasoning to understand, interpret, and apply Scripture does not mean that people are left unassisted, entirely on their own; whether in the form of the voice of conscience, the voice of Scripture, or even a "mysterious" voice, private judgment does not rule out guidance from above. Of course, this does not fully answer the Catholic objection to the multi-denominational reality of a polyphonic Protestantism — why does God lead people to denominations that take different stands based on the same authoritative text? But for Protestant readers it can have the effect of aligning the voice of Heaven with the voice of conscience, making individual interpretation of Scripture not less but more authoritative because through it God, in some form or fashion, speaks directly to the individual.

Finally, the voices and visions utilize the ethos of the ultimate witness: God. In addition to his years as a Catholic and a priest, throughout Fifty Years Chiniquy makes his case by calling on a variety of supporting witnesses. Priests and parishioners, monks and nuns, bishops and popes - and one American president — are all called upon to testify in Chiniquy's inquest. At times, they give their witness via print: Chiniquy constantly quotes Catholic publications to support his arguments. ${ }^{59}$ At other times Chiniquy's witnesses make personal statements in private, especially since their behavior and beliefs (as depicted by Chiniquy) are often scandalous; at times, their testimony is not intentional. ${ }^{60}$ This onslaught of wide-ranging testimony is in keeping 
with Hofstadter's description of conspiracy literature's "elaborate concern” for "demonstration" (35). The "entire right-wing movement" of Hofstadter's time revealed alleged conspiracies through "a parade of experts, study groups, monographs, footnotes, and bibliographies" (37). But in making God his witness Chiniquy has provided greater authentication than a footnote. God himself bears witness to Chiniquy's message that there is a foe to be feared and against which to be fought, whose evil is not entirely obvious, taking place away from public altars, within off-limits convent grounds, and behind closed confessional doors.

Having an omniscient God, via private revelations, as his witness offers an additional rhetorical benefit - the inability of opponents to conclusively disprove him. Indeed, with even many of his human witnesses, this is one of the challenges in disputing the Chiniquy narrative. While he may reproduce an occasional signed letter (644-46) or, rarely, an affidavit (731-32), the vast majority of his claimed eyewitness testimony takes place privately, with no paper trail. Those who could corroborate his story are often anonymous or dead. Consider Chiniquy's use of fellow Canadian and contemporary Maria Monk and her Awful Disclosures (1836). He describes a visit (spring 1847) to Monk's infamous Hotel Dieu, where he talks with an elderly nun who claims to "have known" Monk "well" (441). "She was," according to Chiniquy, "one of the superiors of the house; her family name was Urtubise" (440-41). At one point given Disclosures in order to repudiate it, "after reading it" she "refused to have anything to do with that deplorable exposure." She admits that the book has "some inventions and suppositions"; however, "there is a sufficient amount of truth to cause all our nunneries to be pulled down ... if only the half of them were known. . ." ${ }^{61}$ By both embracing 
and distancing himself from Monk's story via the elderly nun's anonymous and now posthumous witness, Chiniquy is able to have someone who (while acknowledging problems) substantiates its essential validity: its truth outweighs its "inventions and suppositions." As a convent insider, she can say that the account was largely true (while not actually going on the record). But since that nun is now deceased and the conversation was private, Chiniquy has a witness the opposition can neither question nor conclusively refute - a dynamic at work both in his divine visions and his covert talks with the assassinated President.

Did God speak to him? Did Jesus appear to him? Did Chiniquy's mother commission him? Only God knows. But if an audience is predisposed to accept the possibility of divine illumination, or at the least, to be reluctant to deny a Christian minister's claim, then calling on the Unseeable as one's witness is a powerful means of constructing one's ethos.

\section{An Outsider on the Inside: The Ethos of a Nascent Protestant}

While useful in persuading audiences of Catholic hierarchical crimes, ex-priests had potential credibility issues, even among anti-Catholic audiences, for whom Catholicism was constructed in such a way that questions might arise concerning the morality and the intelligence of any person who ever practiced it, including even those who had publicly renounced it. In this section, I first note the credibility concerns raised about Catholic testimony, focusing on gender issues. I next consider, briefly, four means (chronology, genealogy, geography, and exceptionalism) by which the narrative of Fifty Years distances Chiniquy from his Catholic past. I then conclude by examining 
one final distancing move, wherein Chiniquy, in effect, addresses any possible credibility concerns by constructing himself as Catholic who was always, at heart, a Protestant. He is thus able to tap into the believability of an eyewitness while distancing himself from negative connotations.

For both former priests and nuns, questions of gender were at the heart of Protestant concerns with the reliability of ex-Catholic testimony. The ex-nun is unreliable because she has violated the "essence" of her gender as constructed in the nineteenth century: "The most immediate problem the female renegade faces is that by telling her story publicly, she draws her modesty, respectability, and class standing into question" (Griffin 45). While powerful proof of convent crimes, her alleged eyewitness account of priestly sexual sins condemns her as a priestly prostitute, thus undercutting the reliability of her testimony, for as a female she must be modest and chaste. Chiniquy himself represents this cultural norm by speaking of a female "sense of modest and womanly dignity" (581), having one female parishioner proclaim, "God Himself, made, with His own hands, that coat of womanly modesty and self-respect, that we might not be to you and to ourselves, a cause of shame and sin" (598). If what an ex-nun had done — or what had been done to her—in private marked her as immodest, so, too, did her choice to go public. These were topics that a woman was simply not supposed to discuss. In his ongoing attack on the confessional as a trysting place, Protestant Chiniquy speaks of his remorse for having as a priest "persuaded them to give up their self-respect and their womanly dignity to speak with me on matters on which a decent woman should never say a word with a man" (584). Going public with a private crime compromised societal standards of feminine decorum, as Cathy N. Davidson states, 
"Fame, for a woman, is by definition (gender definition), unfeminine, infamous" (qtd. in Griffin 45). In publicly declaring herself a former clerical concubine (as was typical in published ex-nun accounts), an ex-nun proclaimed herself neither innocent nor modest: she had been a whore of Babylon.

If the escaped nun is open to charges of having not been appropriately feminine, a renegade priest could be charged with having been effeminate. Although a priest might be viewed as a Lothario, seducing countless women in the darkness of his confessional, he also could be cast in the role of a willing, submissive slave to an oppressive church master. How then could one trust a man who had not acted as a man? Even though he may no longer be a Catholic, Chiniquy had committed a near unforgiveable gender sin—he, a man, had been the passive, submissive one in the (religious) relationship. Franchot argues, "the alleged psychological seduction of the male by priests" - the Catholic male's "voluntary surrender" to the rule of priests"violated cultural expectations of masculine autonomy" (171). And "[m]ale victims," Franchot continues, "of masculine power risked effeminization." She points to former slave Frederick Douglass, who "well knew, the oratorical display of his own victimization at the hands of his former white masters encroached dangerously on the virility he also proudly claimed" (172). Franchot adds, "Put simply male victims always had to contend with the implication of complicity.” An ex-nun might mitigate her infamy by emphasizing her unwillingness, and an ex-slave could point to the involuntary nature of his previous shackles. But how does an ex-Catholic male who was once — by free-will choice—slave to the "Tyrant of the Tiber" explain his previous 
submission? Would it not have been better, as Chiniquy himself states, "to die a free man than to live a slave" (108)?

Rather than minimizing or ignoring the problematic slavery theme with its connotation of unmasculine submission, throughout Fifty Years Chiniquy connects Catholicism to captivity. First Communion is just "the first ... link" of a "chain of slavery which the priest and the Church has placed around his neck" $(65) .{ }^{62}$ Chiniquy writes of "the ignominy of that slavery!" and places the position of slave within trinities of degradation: "what is a man who cannot make use of his "private personal judgment'? Is he not a slave, an idiot, an ass? And what is a nation [so] composed ... if not a nation of brutes, slaves and contemptible idiots?" (104). The image of the humiliated body captures the despotic nature of the Vatican master. Priests, for instance, hold Catholics "tied as slaves to the feet of the bishops" (799). ${ }^{63}$ And Catholic students are never allowed to rise above the intellectual level of the pope's toes: "when he has raised himself [through education] high enough to be on a level with the big toes of the Pope, he hears ... Stop! stop! Do not raise yourself higher than the toes of the Holy Pope!"” (98). ${ }^{64}$ It is in this light that an embarrassed Chiniquy acknowledges his own former thralldom: "There can be no boasting in me for having been so many years an abject slave of the Pope" (5).

Blurring gender boundaries was not the only credibility issue for ex-Catholic clerics; running through nineteenth-century American culture was the stereotype of the dishonest Catholic—especially, the conniving, dissembling, priest—making participation in Catholicism itself grounds for deep suspicion. In the Protestant imagination, Franchot argues, Catholicism "played the fiction to Protestantism's truth" 
(14). She cites an 1855 magazine piece in the Christian Examiner as one example of the Church as a "yarn spinner," which Franchot describes as a "typically condescending description of the process of beatification [that] assures readers that "no story or miracle can be invented, so preposterous that it may not be overmatched by what is received, sanctioned and magnified in the Sacred City to-day." Of course, these charges, rumors, and folklore defining Catholicism as a superstitious, pagan, immoral, and idolatrous religion were used by ex-clerics in polemic attacks. When Chiniquy attacks John Henry Newman, the nineteenth century's most famous Protestant-to-Catholic convert, he accuses Newman of having a superb "Jesuit ability . . . in giving a color of truth to the most palpable errors and falsehoods." ${ }^{65}$ But Chiniquy himself, of course, must face these assumptions about priestly unreliability.

Chiniquy faces a significant dilemma. His insider ethos provides the foundation for his case-without it, his autobiographical argument collapses. At the same time, his having been a member of a movement that he lambasts as immoral, unmasculine, antiintellectual, and anti-Christian, calls into question his own morality, masculinity, intellect, and faith. How can he maintain the ethos of an insider while not retaining its negative associations? ${ }^{66}$ Why should a Protestant trust an ex-priest who continues to go by "Father" Chiniquy? The autobiography offers at least five means for a reader to distance Chiniquy from the negative connotations of having once been a Roman serf. First, chronology provides rhetorical distance: Chiniquy writes Fifty Years as a man in his eighties. As with the United States, Chiniquy's experience of "slavery" was from the antebellum past not the Gilded Age present (even the title calls attention to the elapsed 
time). Second, birth into a Catholic family offers Chiniquy rhetorical distance. If voluntary submission to an enslaving religion calls into question one's masculinity, Chiniquy's autobiography reminds readers that his former faith was not entirely of his own choosing:. this was a choice made not by him but by his parents, thus mitigating his individual culpability ${ }^{67}$ Third, geography offers Chiniquy rhetorical distance. The fifty years covered in Fifty Years for the most part take place outside the United States, thus largely locating and limiting Chiniquy's Catholicism to his life in Canada, in particular, French-speaking and French-cultured Canada. Locating Catholicism within French Canadian borders allows it to be viewed as foreign, other, in contrast to American Protestantism: he was Catholic there, but not here. And in fact, once he got "here," he became Protestant, thus allowing for a geographic identification between the United States and Protestantism. ${ }^{68}$ Fourth, exceptionalism offers Chiniquy rhetorical distance. Chiniquy, for instance, is told by a soon-to-retire bishop of the rampant immorality of his priests: "They are all either notorious drunkards, or given to public or secret concubinage; several of them have children by their own nieces, and two by their own sisters. I do no think that ten of them believe in God" (559). There are exceptions, but when it comes to priests, the norm is adultery, fornication, alcoholism, and atheism. Chiniquy is an outlier - an exception that proves the rule. Chronology, birth, geography, and exceptionalism all distance Chiniquy from the negative connotations of having once been a priest in the mysteries of Babylon. But there is a fifth rhetorical distancing measure that I consider in the remainder of this section: during his fifty years as a Catholic, including twenty-five as a priest, Father Chiniquy was always already a Protestant. 
The rhetorical power of Chiniquy's narrative rests on his having been an insider in the Catholic Church, privy to its secrets - he is his most compelling proof. However, throughout the book Chiniquy portrays himself, from birth up, as having always been, at heart, a Protestant. And so while he presents himself as having been an insider, he distances himself from that status, too: in effect, he was an outsider on the inside. This positioning allows him to retain the ethos of ex-Catholic eyewitness without the antiCatholic connotations (superstitious, immoral, dishonest) of having once been a Catholic. This Protestantism-throughout also indicates his consistency, his steadfastness, and hence his reliability. The text accomplishes this outsider/insider balancing act in several ways, of which I will consider four: his Protestant-like love of the Bible, his essentially Protestant temperance work, his Protestant questions and doubts, and his being labeled a Protestant by his fellow Catholics.

The Roman Catholic Chiniquy demonstrates his innate Protestantism via his love for the Bible. In the eyes of anti-Catholics, the Bible was a forbidden book for Catholics. Chiniquy aligns himself with these Protestant prejudices, positioning himself as a Bible devotee and his former priestly peers as Bible enemies. Chiniquy, for instance, tells of a meeting with a former convict that he had rescued from execution. The anonymous and now Protestant ex-con admires the ex-priest for having given him his own copy of the New Testament—while Chiniquy was still a priest—something other priests, he claims, would never have done. Like a nineteenth-century Tyndale, Chiniquy was "the only priest in Canada who would put such a book in the hands of the common people" (312). On another occasion, when Chiniquy attempts to build a 
school, he's opposed by fellow priests who fear that education will lead to literacy, and literacy will lead to Bible reading, and Bible reading will lead to more Protestants. ${ }^{69}$ Sounding like a Protestant Bible society representative, Chiniquy reveals his plans to provide a solid education to every child in the community and "to put the gospel of Christ in their hands as soon as they are able to read it" (380). Chiniquy's Bible disbursing ways eventually bring him into conflict (yet again) with (yet) another superior. After having moved to Illinois to work with French Canadian Catholic immigrants, Chiniquy is grilled by his Irish bishop (O'Regan) concerning whether he gives out Bibles to his parishioners (614). Chiniquy admits the charge, infuriating the prelate, leading the bishop to accuse him of being "a disguised Protestant" for "The Bible! the Bible! is your motto!" (616). And with words guaranteed to please Chiniquy's Protestant readers, the bishop states, "For you, the Bible is everything, and the holy church, with her Popes and bishops, nothing!"

In all of this, Chiniquy uses anti-Catholic tropes concerning the alleged antagonism of the Catholic Church to education in general and Bible reading in particular. In this view, the Catholic Church chained the Bible to the pulpit not to safeguard a rare and precious book, but to keep it away from and out of the hands of the laity. These stories additionally position literacy as a Protestant and not a Catholic virtue. Protestants build non-sectarian schools (which in reality teach a generalized Protestantism) for all children to educate and raise themselves—and the nation. Catholics may build convent schools, but they build them to convert Protestant children (with their Protestant dollars) and hide Catholic crimes of priestly passion. Finally, these stories not only make literacy a Protestant virtue but a specific type of literacy a 
Protestant goal: the ability to read the Bible. The Bible, as Bishop O'Regan's remonstrance shows, is a Protestant book. ${ }^{70}$

The Catholic Chiniquy displays his natural Protestantism through his temperance work, which in the United States "had roots in the Protestant Second Great Awakening of early nineteenth-century America," with "[m]any American temperance organizations . . clearly antagonistic to Catholicism" (Moloney 4). However, as the noteworthy antebellum temperance work done in Ireland and the United States by the Irish priest Father Mathew demonstrates, the movement was not entirely Protestant. And Catholic temperance was a cause that even diehard anti-Catholics could encourage. ${ }^{71}$ In contrast, Chiniquy describes most Catholic priests as being antitemperance. Upon being appointed curate of Beauport near Quebec, Chiniquy describes himself as being in "the very nest of the drunkards of Canada" (335). He replaces a priest whom he describes as having "accepted the moral principles of the great Roman Catholic 'Theologia Liguori,' which says, 'that a man is not guilty of the sin of drunkenness, so long as he can distinguish between a small pin and a load of hay" (33536). ${ }^{72}$ Shortly after taking over his new parish, Chiniquy follows in Father Mathew’s footsteps and organizes a temperance society. But for other priests in Fifty Years, alcohol is typically a friend not a foe. ${ }^{73}$ The exceptional Chiniquy thus finds himself "opposed by ... the whole clergy," with his own bishop deriding the temperance society as "clearly heretical" and "Anti-Catholic" (341). It is, according to one of the bishop's colleagues, "the first step" Chiniquy will take toward "sooner or later becom[ing] a Protestant" (346). In response, Chiniquy argues that if true, "it would 
show that Protestantism is more apt than our holy religion to work for the glory of God and the good of the people."

Advocating temperance allows several rhetorical advantages to Chiniquy. Primarily, it allows him to question the ethos of an entire Church, constructing it, from parishioner to priest, as a den of out-of-control behavior. How can the Catholic Church claim to be holy - even Christian — when it does nothing to stem one of the greatest social evils of the age? And rather than curtailing this rampant drug abuse, in the person of its priesthood and hierarchy, it indulges or overindulges, too $!^{74}$ At the same time, temperance allows Chiniquy to build his ethos by self-promoting his own exceptionalism and masculinity. All other priests may fall victim to the temptation of alcohol, but Chiniquy proves himself a man (and not a slave to drink) by bringing his own body and passions under control. ${ }^{75}$ Although not all Protestants or anti-Catholics advocated temperance, among those who did, Chiniquy's temperance work would align him against the Church even while he was a member. Temperance is Protestant. As the narrative unfolds, Chiniquy becomes "the apostle of temperance" (title page, 282, 456, $465,466,497,515,529,611)$, and in so doing gains an apostleship that in Protestant eyes is more important - and more true - than any papal claim to be the Apostle Peter's successor.

The Catholic Chiniquy exhibits his Protestant faith and beliefs through his recurrent questions and doubts: he may don the robes of a priest, but he has a Reformer's conscience. Throughout the narrative, Chiniquy expresses doubts or engages in out-and-out polemics with his Catholic superiors, in the process reiterating classic Protestant arguments and positioning Catholic clergy as intellectual lightweights. 
He constructs Christian faith as logical and reasonable - true faith is compatible and not at odds with reason. In contrast, he paints a Catholic system that is patently absurd; even a child can see its preposterousness. For instance, in describing himself as a boy about to take his first communion, he depicts the struggle as one between a false faith and true reason. ${ }^{76}$ Chiniquy's young self could never fully acquiesce to what reason could not accept: "I had been also greatly in the habit of trusting my eyes, and ... I could easily distinguish between a small piece of bread and a full-grown man!” (62). At the same time, he portrays himself as sincere, a necessary counterpoint to any questions about his authenticity then or now, for if his heart was false in his past, it could be false in his present. But though he acknowledges personal genuineness, he emphasizes theological stupidity. The Catholic boy or girl believes in transubstantiation "as much as it is possible to believe in a most monstrous and ridiculous story, opposed to the simplest notions of truth and common sense. He believes as Roman Catholics believe. He believes as an idiot believes!!” (64-65). ${ }^{77}$

The doubts he shows with his first communion continue into seminary (and beyond). As a seminarian he engages in full-on theological attack, demonstrating his Protestant leanings and developing polemical prowess. After a teacher attempts to persuade Chiniquy's class to accept the celibate life, Chiniquy counters with a clearly Protestant interpretation of biblical proof texts, at the end of which, he is blasted for "speak[ing] of the Holy Scriptures just as a Protestant would" (134). Even while he's being, supposedly, indoctrinated, Chiniquy (in his telling) proves so able a rhetor that shortly thereafter, two fellow students, "disgusted by the sophisms and logical 
absurdities" of the priest, leave the school (139). ${ }^{78}$ While still a Catholic, Chiniquy turns men away from the logical errors of Catholicism.

In so expressing these questions, Chiniquy aligns himself with his readers' questions, doubts, and debates - his parrying with Catholic priests serves as a rhetorical model for his readers. But they also buttress his ethos. Like Socrates, Chiniquy is never bested. He wins every argument; he beats every opponent. Even as a child he knows better than a pope. He is a debater and thinker par excellence. At the same time Chiniquy's questions attack the ethos of the Church: it cannot stand or win debate. Its doctrines are illogical, immoral, and unreasonable. The Church opposes both the spirit and the intellect. It is also easy to defeat: all it takes is a Bible. This of course taps into a fundamental Protestant doctrine and myth — a man alone with his Bible alone (sola Scriptura) can find salvation and understand truth. There is no need for ecclesiastical interpretation. The Bible can be read by the common man and interpreted without church or cleric. And thus a man like Chiniquy, who always on some level understood and practiced that sola Scriptura, is more Protestant than Catholic.

Finally, Protestant readers who wanted to know for sure which side of the Reformation divide Chiniquy really belonged to - and thus whether he could be truly trusted — could listen to the testimony of Chiniquy's fellow priests: throughout Fifty Years, Chiniquy's Catholic peers and superiors “out” him as a closet Protestant. In considering the rhetoric of anti-Catholic literature, this is an interesting and potentially effective device. If ex-Catholics used lifelong Protestants to bear witness to their faith's genuineness, Chiniquy uses Catholic priests to testify to his Protestant faith while he was still a Catholic. For priests in Fifty Years, Chiniquy thinks like a Protestant. In his 
interpretation of Scripture he is accused of "supporting a Protestant error" (138) and having "a fatal tendency to interpret . . . in a sense . . . more Protestant than Catholic" (221). When he remonstrates an elderly priest for engaging in acts of pious selfflagellation, arguing that there is no need to "pay again to the justice of God that which has been so perfectly ... paid by our Saviour," Chiniquy's doctrine is labeled Protestant and "condemned by the Holy Council of Trent" (148). When he advocates for marriage over life in a nunnery, the bishop of Montreal (Bourget) tells him, "This is sheer Protestantism" (516). ${ }^{79}$ As a result of his essentially Protestant preaching-while still a priest - Chiniquy is warned that his unorthodox thinking may lead him away from the Church: "If you do not take care, you will become another Luther!" (149). But there is no need to warn Chiniquy about becoming Protestant — he already is one. He may spend fifty years in the Church of Rome, but he spends those fifty years protesting against the Church, the behavior of its priests, and the doctrine of its popes. Catholic Chiniquy is in reality a "disguised Protestant" (787). ${ }^{80}$ Indeed, the villains of his narrative, the priests and bishops, are correct in that Chiniquy is a not a child of St. Peter but a son of the Reformation. Even while still a Catholic, Chiniquy is "a secret Protestant emissary" (614).

As important as ex-priests were in the nineteenth-century Protestant/Catholic debates, clerical converts did not always stay converted: as Paz shows in his discussion of ex-priests, sometimes they returned to their former faith or left religious faith entirely (5-6). And for those who did stay converted, there were still concerns about their authenticity. But Chiniquy the Protestant author constructs his former self in such a way as to maintain the rhetorical power of his eyewitness testimony to alleged Catholic 
improprieties while responding to concerns about his trustworthiness as a former participant in Catholicism: Chiniquy the Protestant narrator creates Chiniquy the nearly Protestant Catholic. In Fifty Years, Chiniquy's spiritual journey from priest to preacher was, in a sense, not a conversion but a revelation of an already existent "herectical" faith that pre-existed his formal conversion. His baptism, training, and twenty-five-yearlong ministry may have been Catholic, but his conscience, heart, and soul were always already Protestant.

\section{Conclusion}

I began this chapter with this question: How does the renegade ex-priest construct himself in such a way as to persuade the American public that he should be believed and trusted when he makes his anti-Catholic conspiracy argument? To begin answering this query, in this chapter I have explored how Chiniquy—-the Protestant author-constructs his personal journey from priest to preacher in such a way as to establish a credible ethos among his readers. Since Chiniquy's conspiracy argument is so closely intertwined with his own experience and character, successful ethos construction is essential to persuasion. In order for Chiniquy's Lincoln conspiracy narrative to succeed as rhetoric, Chiniquy must persuade readers to trust him and to believe in him. This effort begins in the paratext and continues on in the main text of Fifty Years. Fifty Years confirms Creps's argument that those who advocate for the existence of a conspiracy position themselves as crusaders, experts, and victims. In addition to Creps's three-fold model, I have added two other elements - the ethos of visionary and that of an outsider/insider. 
Chiniquy's five-fold ethos construction provides a useful heuristic for examining other renegade narratives. Renegade rhetoric is not necessarily conspiratorial; however, as Hofstadter described, the renegade has a "special significance" in prominent anti movements of the past (anti-Masonry, anti-Catholicism, and anti-Communism) (34), all of which depended heavily on conspiracy allegations. Renegades were used to confirm suspicions, to reveal a menace that would, unchecked, destroy the American republic. A "special authority" is given the renegade, according to Hofstadter: "the renegade . . . has been in the arcanum, and brings forth . . . the final verification of suspicions which might otherwise have been doubted by a skeptical world" (35). Renegades revealed the secret workings; they demonstrated to the outside world what was truly going on in the convents, monasteries, seminaries, and the Vatican itself. They showed what the Catholic Church would do to a Protestant America. Though more or less explicitly conspiratorial, ex-priests and ex-nuns were key players in demonstrating the greater plot of Rome against America.

Other ex-priests, active in the late-nineteenth through early-twentieth centuries, published anti-Catholic books; among these were Joseph Slattery's Secrets of Romish Priests Revealed (1892), Bernard Fresenborg's Thirty Years in Hell: Or, From Darkness to Light (1904), and Peter Seguin's Out of Hell and Purgatory: The Most Powerful Blow Ever Struck the Romish Hierarchy (1912). ${ }^{81}$ As with Chiniquy, all three authors' own experiences serve as the fundamental authority for their claims, to which the inflammatory titles of their books allude: Fresenborg has spent thirty years in Hell, Seguin has (Dante like) left Hell and Purgatory, and Slattery can reveal the secrets of Romish priests. ${ }^{82}$ Fresenborg states, "What I will now relate is not hear-say nor 
something that I have read about, but it is something that [I] know about, and which I witnessed" (ch. 2) ${ }^{83}$ All three authors present themselves as crusaders. For instance, the title page to Seguin's work describes him as one who "stands at the Vatican's door, with the torch of Protestant wisdom, and denounces Popery with a tongue livid with the power of a living God," while his "great book" is "[1]ike a meteor from God's throne" that "has stirred America from center to circumference." ${ }^{\prime 44}$ All three authors also present themselves as experts in matters of interpreting both Scripture and Catholic doctrine, with all three having an expertise born of experience: "I know whereof I speak, as I have traveled this Romish road of despair for thirty years" (Fresenborg ch. 2) ${ }^{85}$ And all three present themselves as having been, in some way, victimized by Catholicism. Slattery describes his home Ireland as country tyrannized by the Church. And though he does not detail a great deal of post-conversion persecution against him, he does question why "Rome acts so harshly towards one that leaves her" $(61){ }^{86}$

Unlike Chiniquy, however, none of these three renegade priests use the visionary construction. None of them, for instance, present themselves explicitly as having always been at heart a Protestant. Rather than being Protestant-like students of Scripture while still Catholics or priests, Slattery and Seguin admit a deep ignorance of Scripture. Slattery says of his early Catholic education, "no young man ever saw a Bible there" (17); and when describing his leaving the Church, he explains why he didn't turn to the Bible for guidance: "That blessed book was practically to me a closed one (61). And Seguin explains his ignorance, while still a priest, of a particular Scriptural passage as reflecting how "Priests in general are very ignorant about Bible teachings" (48). Although this self-presentation is at great variance with Chiniquy's, it still provides a 
connection with an anti-Catholic readership, for it depicts a biblically ignorant Catholic Church that allows for a sense of non-Catholic superiority: the Protestant in the pew knows more Bible than the priest behind the altar.

There are elements of an outsider/insider ethos construction in these renegades' "reports": Fresenborg presents himself, like Chiniquy, as having doubts about the Church while still a member. "Oftentimes," he writes, "I would have my faith shaken by the actions of some lustful priest"- a lust not directed toward himself, but toward a woman (or women) (ch. 1). ${ }^{87}$ And yet, like Chiniquy, he fights against his conscience: "I fought this feeling of dislike down and forced myself to believe that what a priest or bishop did was all right in the sight of God" (ibid). Eventually, his doubts win out, and he "burst[s] the bands of iniquity and walk[s] out upon the plains of Protestantism" (ch. 1) ${ }^{88}$ As with Chiniquy, geography provides Fresenborg the ability to distance himself from his Catholic past. Fresenborg, a German immigrant, connects his conversion to his time in America: "As I have lived in America . .. and seen so much of the intelligence of Protestantism, and so much of the deception of Catholicism, I could not remain in the Catholic Church" (ch. 1). ${ }^{89}$ Geography—or America—saves. What happens in Germany, stays in Germany.

While these authors do not explicitly present themselves as men who were always, at heart, Protestants, they might be achieving something similar by describing themselves as moral men while still Catholics. There was a move by anti-Catholic polemicists to contrast life in Protestant countries with that of Catholic countries, with the Catholic nations depicted as bastions of illiteracy, immorality, etc (see Fresenborg's Chapter Nine, "The Characters of the Followers of Catholicism Compared to the 
Followers of Protestantism"). By portraying themselves as moral and temperate (or, at the least, not describing themselves as immoral drunks), these ex-priests set themselves in contrast to the immorality they depict among the clergy. They lived like ministers, not priests; they lived like Protestants in the midst of Catholic countries. In essence, they situate themselves as having always already been Protestant and not Catholic in behavior.

Concerning the visionary ethos, Slattery does not speak of having heard voices or been given a vision - he covers his actual conversion experience in a matter of paragraphs. Fresenborg does speak briefly of having been "bound" to a "bewitching spirit of darkness by the chords of superstition" "until a 'something' which I will call 'fate' broke the windows of my mental dungeon and permitted the light of 'SPIRITUAL LIBERTY' to filter through my being" (Author's Announcement)..$^{90}$ But Seguin does speak of a visionary experience during his conversion, which is most interesting in light of his relationship with Chiniquy. Neither Slattery nor Fresenborg mention Chiniquy (although Fresenborg does mention the Catholic plot against Lincoln). But Chiniquy shows up throughout Seguin's Out of Hell; in fact, according to the caption for an illustration of Chiniquy, Chiniquy is Seguin's “Father In the Protestant Faith" (279). Seguin describes his conversion experience in two stages: first, he becomes a Protestant; second, he becomes a Christian. After realizing that he cannot remain a Catholic, Seguin does not consider himself yet saved—but salvation comes in a visit (1880) to Chiniquy's Illinois home. Here he experiences the goodness of Chiniquy — and a "still small voice from God" (71), who leads him to salvation, and in terms of ethos, the ultimate witness. 
Finally, although my case study focuses on Gilded Age anti-Catholic conspiracy argument, I would suggest that this fivefold ethos construction template can be used as a heuristic for exploring other types of conspiracy narratives. In light of the work already done by Creps, and my own case study, I will not focus on Creps's three-fold ethos template (crusaders, experts, and victims). Instead, I suggest how the visionary and the outsider/insider ethos construction might work in contemporary conspiracy theories. As stated earlier, this template is not a cookie-cutter, one-size-fits-all approach to conspiracy argument. The historical, social, political, and rhetorical situation that gave rise to Chiniquy's autobiographical conspiracy charge differs from those that generated, for instance, the Obama "birther" or 9/11 "truther" movements. But while the parallels are not always exact — indeed, how could they be — there are definite points of comparison (and not just contrast) between how ethos works in Chiniquy's conspiracy and other conspiracy theories, both past and present.

Contemporary conspiracy theories do use visionary ethos. For instance, former BBC sportscaster and Green Party spokesman David Icke advocates what Barkun labels, "New Age conspiracism” (103). Icke's own Facebook page describes him as “an inspiration to a new generation of conspiracy theory researchers around the world" ("David Icke Info"). ${ }^{91}$ Icke advocates that the world is controlled by alien reptiles who take on human forms - "shape-shifting reptilians occupying the positions of global power" - with one of these lizard kings being the Queen of England ("David Icke Biography 2")..$^{92}$ Icke's beliefs have had a surprising popularity, resulting in a presence in bookstores and the Web, as well as the lecture circuit. Part of Icke's ethos is 
visionary, being built on his having experienced voices that led him to a psychic healer who, during a session with him, saw a "figure" who, one might say, commissioned Icke for his mission: "Sometimes he [Icke] will say things and wonder where they came from. They will be our words. Knowledge will be put into his mind, and at other times he will be led to knowledge" ("David Icke Biography 1"). ${ }^{93}$ While Icke and Chiniquy are separated by centuries and deities (Chiniquy would no doubt condemn Icke's New Age philosophy), they are united in their appeal to someone or something beyond themselves. ${ }^{94}$

Concerning the outsider/insider ethos construction, believers in contemporary conspiracy theories do, at times, claim inside information while distancing themselves, personally, from having been a part of the conspiracy. One means is to have an anonymous informant point them to clues or provide evidence (photographs, videos, testimony, secret documents). Thus, a modern conspiracy theory believer can claim inside evidence without the negative connotation of having been a part of the plot or the nefarious institution. In this case, the alleged informant acts like an ex-clerical renegade: he or she is an insider but with some disposition to be an outsider. Why else would he or she provide the documents proving a government cover-up of UFOs? Perhaps also "mind control" provides an example of outsider/insider ethos. Fran Mason writes that "[a]11 conspiracy theories are based on a notion of mind control ... simply because they are based on the belief that a conspiracy is trying to control people's beliefs and actions" (480). Mason describes how those subject to mind-control in these conspiracy theories have "an ambiguous status" concerning whether they are "inside or outside the conspiracy": "On the one hand, they are 'inside' because they are doing the 
work of the conspiracy group as a result of their condition, programming, or physical implant, but on the other hand, they are 'outside' because they are doing so unwittingly as part of a conspiracy where they are a key element, but have no control over their actions" (481). Again, the differences between Chiniquy and modern mind control subjects are substantial. But while he was no Manchurian candidate, Chiniquy shares with them the outsider/insider ethos.

Other men wrote and had published exposés of their lives as priests. Several of them appeared on the nineteenth- and early twentieth-century anti-Catholic lecture circuit. Their stories were repeated in the anti-Catholic press, and their works were spread. However, to the best of my knowledge, none have survived into the twenty-first century to the same degree that Chiniquy's has. His book is available on Kindle, as a graphic comic, as an abbreviated (yet still 368-page) book, and throughout the World Wide Web. Why? What was there about him that leads to his book still being used today? There are a variety of factors. He had been, in Canada, a popular and famous priest. And he certainly was the most prominent ex-priest in North America during the nineteenth century. But in addition, I argue that he succeeded with his ethos construction to a greater extent than others. One can order an abridged version of Fifty Years for less than $\$ 20$ on Amazon; but Joseph Slattery's book requires an inter-library loan of a microfilm.

In the next chapter, I will focus on Chiniquy's conspiratorial vision of Confederate-friendly Vatican and its assassination plot against the Savior of the Union. Without the Lincoln narrative, in which Chiniquy constructs an ethos for himself as a 
friend of the president and an ethos for Lincoln as an enemy of the Catholic Church, Chiniquy would have faded to the obscurity of other Gilded Age ex-clerics. But again, while there are multiple factors involved in his conspiracy's longevity and popularity, ethos plays a key role.

${ }^{1}$ It is not always simple to determine what elements make up the paratext or the main text of a book. Genette acknowledges, "we do not always know whether these productions ["verbal or other"] are to be regarded as belonging to the text" (1); the paratext is a "zone without any hard and fast boundary" (2).

${ }^{2}$ Genette writes of an "official" paratext (9), which he describes as "any paratextual message [such as the title] openly accepted by the author or publisher or both" (10); Genette posits that "something is not a paratext unless the author or one of his associates accepts responsibility for it, although the degree of responsibility may vary (9). Concerning the relationship between Chiniquy and the official paratext, I am unable to state the degree to which - if any - Chiniquy himself guided selection or composition. Of the early editions of Fifty Years available to me, some variations exist (such as the lack of a frontispiece). However, it is not necessary to determine the originator of these elements in order to examine how Chinqiuy's ethos is constructed in the paratext.

${ }^{3}$ The paratext does not always remain stable. As different editions of a book are published, over time by different publishers, and aimed at perhaps slightly different audiences, the paratextual elements change. In the case of Chiniquy's Fifty Years, there are multiple publishers (in the United States and abroad) in multiple languages and different formats - at least one abridged edition, a comic-book edition, and pamphlets or printed lectures based on (or giving rise to) different chapters in the book. In the early editions (published in the late-nineteenth through early-twentieth centuries) I have seen of the book, several significant paratextual elements remain constant or only vary slightly, including the title page, dedication, and note to a new edition. I have chosen an early edition of the book (Adam Craig: Chicago, 1888), published during Chiniquy's lifetime, now digitized and available via the excellent Internet Archive's Open Library. This particular copy has benefits over the first American edition, such as a double frontispiece, illustrations, and the preface to the third edition - it also has an inscription from Chiniquy himself. Dated October 26, 1888, and written in Lewiston, Maine, Chiniquy writes, in part, to a recipient (whose name and title, unfortunately, are not fully legible), "Presented ... as a token of Christian esteem by the author." http://openlibrary.org/books/OL13498039M/Fifty_years_in_the_Church_of_Rome. ${ }^{4}$ An "insider" ethos is related to an "expert" ethos; however, the two are not the same: not all experts can claim insider status. Various Protestant polemicists would have presented themselves as experts on Roman Catholicism, but they would not have claimed to have ever been insiders (former Catholics).

${ }^{5}$ Chiniquy describes the "majority" of works against the Catholic Church as being so "dry" that most who start reading them won't finish (4). In contrast to these boring 
tomes, Fifty Years is, according to Reverend D. Badenoch, the "learned and zealous champion of Protestantism in Great Britain" (5), a Protestant book without peer-one "thrilling in interest" (qtd. in Chiniquy 5).

6 http://openlibrary.org/books/OL25399515M/Exposures

${ }^{7}$ Brown describes the Christian use of "the Word to transform the world" as "one of the central themes in American religion" (17).

8 "In part because of evangelical efforts to establish Sunday and common schools and to make cheap, printed texts more readily available in rural areas, American literacy increased rapidly in the nineteenth century. . . By 1850, the U.S. Census reported a literacy rate of 90 percent among white women and men, compared with an adult literacy rate of 60 percent in Britain" (Brown 10).

9 See Richard Ohmann's "Diverging Paths: Books and Magazines in the Transition to Corporate Capitalism" (102-115) in volume 4 of the A History of the Book in America series, Print in Motion: The Expansion of Publishing and Reading in the United States, 1880-1940 (2009), edited by Carl F. Kaestle and Janice A. Radway. Ohmann states, "In the late nineteenth and early twentieth centuries, magazine publishers radically transformed the economics of their business, which then expanded far more rapidly than book publishing" (103). He points to a surge in production: "total U.S. circulation of monthly magazines rose from about 18 million in 1890 to 64 million in 1905, or nearly four magazines per month per American household, far outpacing weeklies, newspapers, or books" (103). See also Richard L. Kaplan's "From Partisanship to Professionalism: The Transformation of the Daily Press" (also in Print in Motion, 11639). Kaplan states, "From 1870 to 1910 , the press rapidly expanded to reach many more Americans. This media growth was driven by innovations in printing technology, increasing advertising revenues, lower paper costs, and the drive for greater profits" (116). Finally, see Justin Nordstrom's Danger on the Doorstep: Anti-Catholicism and American Print Culture in the Progressive Era (2006) for a discussion of the almost shocking level of popularity attained by the anti-Catholic (or "patriot") press in the early twentieth century. In 1915, the virulently anti-Catholic The Menace, published in Aurora, Missouri, had a circulation of 1, 469,400, outstripping the combined circulation of Harper's Weekly, The Atlantic Monthly, McClure's Magazine, and Collier's (56-57). 10 These works vary in length: Rome and Education is 16 pages; Papal Idolatry is 58 pages; Manual is 113 pages; and The Priest, the Woman and the Confessional is 296 pages.

11 See Lougheed's bibliography for a listing of Chiniquy's works, including nonEnglish translations (347-51).

12 The Manual was first published in French (the Manuel). According to Lougheed, it was Chiniquy's "first book ... [and] a best seller in French Quebec" (307);

additionally, "Pope Pius IX examined the Manuel and sent his benediction for the work of an 'apostle of temperance"" (47). The book's paratext features endorsements from four Catholic bishops and is dedicated to the bishop of Montreal.

${ }^{13}$ Chiniquy's title echoes Jules Michelet's Priests, Women, and Families (Trans. C. Cocks. $12^{\text {th }}$ ed. London: Longman, Brown, Green, and Longmans, 1847), perhaps the most famous of this genre. 
14 For an example of an at least initially self-published ex-priest tale, see Jeremiah Crowley's Romanism: A Menace to the Nation: (A New and Original Work) Together with My Former Book "The Parochial School, a Curse to the Church, a Menace to the Nation." (Cincinnati: J.J. Crowley). 1912. Available at http://archive.org/details/romanismmenace00crowiala.

${ }^{15}$ For history on the Fleming H. Revell Company, see "The History of Fleming H. Revell" at the Baker Publishing Group website:

http://bakerpublishinggroup.com/revell/about-revell. (Baker purchased Revell in 1992.) Concerning the Gilded Age success of Revell, "History" states, "With the solid foundation of works by Moody and Meyer, as well as best-selling inspirational titles by authors like Smith and Connor, Revell established itself as the largest American publisher of religious books. By the early 1890s, it was releasing over 300 books a year. It had offices in Chicago, New York, Toronto (this office acquired through the purchase of the Toronto Willard Tract Depository), London, and Edinburgh. When the American Publishers' Association was formed in 1900, twenty-seven companies were invited to join. Revell was one of them."

16 The word "edition" here need not be understood in a contemporary sense as reflecting a revised and at least somewhat different version from 14 previous revised and changed versions. During the nineteenth century, the edition number could mean the same as today's number of printing. Hence, this would be Craig's $15^{\text {th }}$ printing of the book. 17 Although exact publication numbers for Fifty Years do not exist, Kinzer speaks of it "reach[ing] a fortieth edition by 1891" (31).

${ }^{18}$ Besides the Orangemen, the "liberty loving" people of the United States, and Roman Catholics, the book is dedicated to one individual (Col. Edwin A. Sherman) and one other group: "faithful ministers of the Gospel." In terms of length, the dedication to the Protestant ministers, at roughly $13 / 4$ pages, is significantly longer than the other sections, perhaps indicating who Chiniquy saw as his main audience.

19 "I should be glad if his words could be sent to into every house throughout the land" ("Romanism" 6).

20 The table of illustrations lists both portraits, found separately before the title page, as frontispiece.

21 Other ex-priests used visual evidence of their days as Catholic priests. The frontispiece for Joseph Slattery's Secrets of Romish Priests Revealed (1892) features a photograph of Father Slattery wearing a priestly collar. Peter Seguin's Out of Hell and Purgatory: The Most Powerful Blow Ever Struck the Romish Hierarchy (1912) has a series of three photographs prior to the title page. The first depicts Seguin as of the writing, with the caption, "As I am Now at the Age of Seventy-two Years, 1842-1914. Still on the Battle Field for God and Humanity." The second and third pictures (taken at different ages) depict Seguin dressed in priestly clothes. The caption for the second states, "As I was When a Priest of Rome," and the caption for the third, in which he holds a rosary, "Ex- Priest P. A. Seguin Exposing the Superstitions of Romanism." In Out of Hell, Seguin writes of his relationship with Chiniquy, claiming to have been converted during a stay (1880) with Chiniquy in Illinois.

22 The latter portrait comes from an 1846 painting done while Chiniquy lived in Montreal. 
${ }^{23}$ Chiniquy writes in Fifty Years of being invited (1878) by "the noble-hearted Orangemen" to come lecture in Australia (311).

${ }^{24}$ In his 1892 Secrets of Romish Priests Exposed, Joseph Slattery, another prominent Gilded Age ex-priest, makes a similar division, writing of "so-called Protestant churches" who "have a great tendency toward Popery," for which he blames Jesuits who have "infiltrated our ranks" (viii).

${ }^{25}$ For those Protestants would dare for even a moment to "consider her [the Catholic Church] almost a branch of the church whose corner-stone is Christ" (5), Chiniquy issues an altar call to Catholics: by reading Fifty Years, "You will see that it is not through your ceremonies, masses, confessions, purgatory, indulgences, fasting, etc., you are saved. You have nothing to do but believe, repent and love" (6).

${ }^{26}$ Chiniquy, the French Canadian immigrant and international speaker, cannot be limited to one nation. He utilizes the endorsements of a British and a Canadian minister, and spans the oceans by dedicating his book, in part, to Orangemen in Australia, New Zealand, and Tasmania, as well as those in Great Britain.

${ }^{27}$ I am quoting from (Viren) Swami et al. ("Conspiracist ideation in Britain and Austria:

Evidence of a monological belief system and associations between individual psychological differences and real-world and fictitious conspiracy theories" 2011), which summarizes previous research led by Swami: "In perhaps the most robust empirical investigation to date, Swami et al. (2010) examined the individual difference correlates of 9/11 conspiracy theories among a representative sample of British respondents. They reported that belief in 9/11 conspiracy theories was strongly associated with belief in other conspiracy theories and exposure (either directly or vicariously) to $9 / 11$ conspiracist ideation. In addition, they also reported significant associations between 9/11 conspiracist ideation and more negative attitudes towards authority, higher political cynicism, and greater support for democratic principles (SDP)" (445).

${ }^{28}$ Chiniquy addresses Sherman as Colonel; however, Sherman's rank was that of Major, as can be seen on letterhead that he signed, made available by the University of California here: http://content.cdlib.org/ark:/13030/kt1b69p3f8/?layout=metadata 29 In June 1883, Sherman moved to Oakland, California, "where he remained for the rest of his career as mining expert, author, and contributor to San Francisco newspapers and magazines" (Alan B. Sherman 260).

30 The 1884 election would witness the first Gilded Age president elected (Grover Cleveland) who had not served as a Union general. Excepting Andrew Johnson, a Democrat who had run with Lincoln on a national union ticket, Cleveland was also the only Democrat to serve as president between 1861-1912.

$31 \mathrm{http} / /$ archive.org/details/engineercorpsofhe00sher

32 Sherman is listed as a $32^{\circ}$ Mason in his 1883 The Engineer Corps of Hell; Or Rome's Sappers and Miners, which was published prior to Fifty Years. By the 1890 publication of his New Edition of the Brief History of the Ancient and Accepted Scottish Rite of Freemasonry for the Information of Master Masons and Brethren of the Rite he is listed as a $33^{\circ}$. 
33 These works include Fifty Years of Masonry in California (1898), Brief History of the Ancient and Accepted Scottish Rite of Freemasonry for the Information of Master Masons and Brethren of the Rite (1885), and the Brief History, Constitution, and Statutes of the Masonic Veterans Association of the Pacific Coast with the List of Officers and the Entire Roll of Members from . . December 27, 1878 to January 1, 1901 (1901).

34 "Conspiracists take it for granted that the Illuminati are linked to the Jesuits through some Masonic network" (Barkun 133).

35 For an example of a nineteenth-century prohibition, see Pope Leo XIII's encyclical on freemasonry, "Humanum Genus," available here:

http://www.vatican.va/holy_father/leo_xiii/encyclicals/documents/hf_1xiii_enc_18840420_humanum-genus_en.html

36 Available at http://www.vatican.va/roman_curia/congregations/cfaith/documents/rc_con_cfaith_doc 19831126 declaration-masonic en.html

37 The title page lists these as Sherman's credentials: "Past Grand Registrar of the Grand Consistory of the 32d Degree of the Ancient and Accepted Scottish Kite of Freemasonry of the State of California, and Secretary of the Masonic Veteran Association of the Pacific Coast, etc."

${ }^{38} \mathrm{He}$ discloses the back-story for a portion of his book by telling a cloak and dagger tale involving "a stranger" who appeared unannounced at Sherman's Masonic Temple office in 1870 San Francisco (5). The stranger was "a member of and explorer for various scientific societies in Europe, but more especially for the Archaeological Society of France, with its principal seat at Paris, and with its members and correspondents scattered throughout Europe and America. He was a Frenchman, and, if we mistake not, a Huguenot." The never-named stranger unveils himself to be a Masonic international man of mystery, who proceeds to tell of his discovery in South America of a secret Jesuit manual accidentally left by a Jesuit bishop. The archaeologist has the manuscript translated into Spanish and distributed to Masons in Peru. "But alas!" there were covert Jesuits even among his supposed Masonic brothers, causing him to flee, "run the gauntlet," and be "shot and stabbed in the back." "But alas!" there were covert Jesuits even among his supposed Masonic brothers, causing him to flee, "run the gauntlet," and be "shot and stabbed in the back" (11). He travels to San Francisco, bearing the Spanish translation of Jesuit secrets: "If I could get it translated into English and have it printed," states the nineteenth-century Masonic Indiana Jones, "it would be a most valuable weapon in the hands of the Masonic fraternity." Catholicism was no friend to Masonry, but rather an oppressor to be opposed with whatever weapons could be found.

39 The exact date for the Banks/Briggs edition is uncertain, though it's probably very early and published in the 1880s. It does not feature, as other early (non-first) editions do, Chiniquy's note about the plates for Fifty Years being burned after the second publication - an odd omission unless the Banks/Briggs edition was printed prior to the fire. Parts of Chiniquy's message to the Masons are used in Reverend Charles E. Perry's 1892 Lectures on Orangeism and Other Subjects (Toronto: William Briggs, pp. 10405). Perry quotes and cites Chiniquy; however, he gives no specific attribution to Fifty 
Years. The Banks/Briggs edition is available here:

http://ebooks.library.ualberta.ca/local/cihm_26940. Perry's book is available here: http://openlibrary.org/books/OL14018688M/Lectures on Orangeism and other subje cts

40 The "Freemasons," he claims, "were the chosen ones of God" to help Garibaldi, and thus "Christians owe them a debt of gratitude which they will never be able to pay, in their long and successful efforts to break the heavy and ignominious yoke of the Pope over Italy and the whole world" (iv).

41 This particular message to Masons, though found in the Banks/Briggs edition, is not printed in the other early editions that I have examined; it is the most significant difference among paratextual elements in the early editions of Fifty Years. The reason for its omission is not readily apparent. Perhaps it stems from potential complications in associating too closely with Masonry. While the Masons might prove to be an audience especially open to Chiniquy's anti-Catholicism, they also brought with them a certain amount of cultural baggage for those who oppose Catholicism and Masonry: if antiCatholicism has a long-standing place in American life, so, too, does anti-Masonry. By dropping the dedication to the group while yet retaining that to the individual Mason (Sherman), the paratext allows for a less obvious and less problematic alignment with and appeal to Masons. Chiniquy's dedication to one of their own in the head position would help place Chiniquy in a favorable light among those who knew Sherman's Masonry while not turning away those favorable to anti-Catholicism but not Freemasonry.

42 The paratext would have helped situate the book's narrative or main text as autobiographical, stressing, for instance, Chiniquy's personal experience in the title itself: the book is not a general overview of Catholic history; rather, it is a book about Chiniquy's fifty years in the Catholic Church.

43 UFO abduction stories are not inherently conspiratorial, but they can become conspiratorial when, for instance, mixed with allegations of a government cover-up. ${ }^{44}$ And it opposes Chiniquy in particular because he is no longer their dupe. He understands the true nature of the Church, and publicly, at great cost, he reveals their sinister religion.

45 Though dating from the early 1900s, consider the alleged "Fourth Degree Oath of the Knights of Columbus," which has initiates pledge "I will burn, hang, waste, boil, flay, strangle, and bury alive these infamous heretics." See Thomas Watson's 1928 book on the oath here: http://openlibrary.org/books/OL22877085M/The_4th_Degree_oath_of the_Knights_of Columbus

46 When the holiday ends, Chiniquy confronts the college director about why the students are taught the best of uninspired literature but not the Gospel. After a brief discussion, the teacher acknowledges that the student has bested him - "your arguments have a force that frightens me, and if I had no other but my own personal ideas to disprove them, I acknowledge I do not know how I would do it" (84).

${ }^{47}$ The voices speak to him as if they were something other than him-the voice originating in Chiniquy's mind distances itself from Chiniquy by calling him "you." For instance, while in a monastery praying to God and Mary, a "thought came involuntarily 
to [Chiniquy's] mind": "Have you not, a thousand times, heard and said that the Holy Church of Rome absolutely condemns and anathematizes secret societies? And, do you not, to-day, belong to a secret society [the monastery]?" (emphasis mine, 433).

Although there is distance between the voice and Chiniquy - the voice calls Chiniquy "you" not "I"- Chiniquy includes it as part of his "rebellious intelligence" and "private judgment." Additionally, it should be noted that there is at least one instance (437) where he is clearly talking with himself and yet he uses the language of distance - and, oddly, the "thou" and the "thyself" of the King James Bible, which is not characteristic of his voice's stylistic voice.

${ }^{48}$ See especially chapter 36 where Chiniquy deals at some length with the Catholic violence against "intelligence" in general, connecting it to a person's inner or voice of intelligence.

49 "Do you not see that the bishops and priests of your church do not believe a word of their religion? Their only object is to throw dust in the eyes of the people, and to live a jolly life. Do you not see that you do not follow the Word of God, but only the vain and lying traditions of men, in the Church of Rome? Come out of it; break the heavy yoke which is upon you, and follow the simple, pure religion of Jesus Christ" (503).

${ }^{50}$ The unnamed mother gets drunk, grabs her young child to hug her, slips, falls, and bashes the child's head on a stove, killing her.

${ }^{51}$ In so doing, she (or Chiniquy the author) makes a disturbing use of Passover imagery: "Take the blood of my child, and go redden with it the top of the doors of every house in Canada, and say to all those who dwell in those houses that the blood was shed by the hand of a murderous mother when drunk" (278-79)

52 "Is it possible that the terrible things I have seen and heard these last few days will destroy my mind and send me to the lunatic asylum?" (280)

${ }^{53}$ But even in this moment of self-abasement, Chiniquy can still entertain a grandiose self image. He imagines that his abjuration will cause the entire Catholic Church to focus on him: "I felt that an implacable war was to be declared against me, which would only end with my life. The Pope, the bishops and priests, all over the world, would denounce and curse me. They would attack and destroy my character, my name and my honor, in their press, from the pulpit and in their confessionals. ... Every one of the millions of Roman Catholics were bound to curse me" (792).

${ }^{54}$ For one who has portrayed himself as a serious student and devotee of the Bible, Chiniquy has taken a long time - several hours - to remember that he has a Bible with him.

${ }^{55}$ He screams to God so loudly that he is "heard by many in the hotel."

56 The vision's emphasis on the nature of salvation as a "GIFT" harkens back to the dedications page, when Chiniquy promises Catholic readers that if they read his book they will find the gift of eternal life and the salvation of their souls: "you will look to the GIFT — you will accept it — and in its possession you will feel rich and happy for time and eternity" (6).

${ }^{57}$ In spite of all he had done as a devout priest, "My good works seemed only as a grain of sand compared with the weight of my sins" (321).

${ }^{58}$ Douglas tells the recovering Chiniquy: "The vision was what we call the turningpoint of the disease, when the mind is powerfully bent on some very exciting object, 
when that mysterious thing of which we know so little as yet, called the will, the spirit, the soul, fights as a giant against death, in which battle, pains, diseases, and even death, are put to flight and conquered" (326). But lest Douglas's post-illness analysis seem too secular, Chiniquy includes the scientist's admission that "[i]t is surely God who has given you that irresistible will," and "[i]n that sense only does your cure come from Him" (326-27).

Douglas is not the only Protestant to question Chiniquy's miracle-a secret Protestant (331), in the person of an older cousin, a fellow Catholic cleric, attacks the supernatural explanation. When it comes time for the promised portrait of the two healing saints to be publicly displayed, Chiniquy travels to the church that it will adorn-a church whose curate is his cousin, the Rev. Ranvoize. The night before the painting's unveiling Ranvoize horrifies his cousin with his covert Protestant leanings, calling into question not only Chiniquy's miracle and vision but all Catholic claims to divine intervention. Sounding like the Protestant physician, the Catholic-in-name-only cousin tells Chiniquy, "Your so-called vision was a dream of your sickly brain, as it generally occurs at the moment of the supreme crisis of the fever. It is what is called the 'turning-point' of the disease, when a desperate effort of nature kills or cures the patient" (328). ${ }^{58}$ The elder priest goes on to explain how the supposed miracles at his church - "numberless crutches" were "suspended all over the walls"-are "ninety-nine out of a hundred" times the result of duplicity and not divinity. Although their conversation stretches on for hours, Chiniquy remains unconvinced of his cousin's message. The next day, the picture, which portrayed Chiniquy "dying in my bed of sufferings" with "the two saints . . . above me, stretching their hands, as if to say, "You will be cured' (332) is dedicated in the church of the elderly priest who "was secretly a Protestant" (331).

${ }^{59}$ Chapter 59, for instance, contains a multi-page litany of quotations isolated from a variety of Catholic authors.

60 Although he repeats in the open what those involved would prefer to be kept in secret, Chiniquy sometimes keeps a secret, at least for a time. Upon being told of a priestly murder, in which a grand vicar poisoned a bishop over a nun, Chiniquy promises that he "would never reveal the fact before the death" of his priestly informant (507).

61 The talkative sister pleads with Chiniquy to "not reveal these things . . . till the last one of us is dead." While honoring her request, Chiniquy eventually removes his veil of silence: "But I think it is my duty to reveal to my country and the whole world the truth, on that grave subject, as it was given me by a most respectable and unimpeachable eyewitness" (442).

62 "The Pope holds the end of that chain, and with it he will make his victims go right or left at his pleasure, in the same way that we govern the lower animals" (65).

63 At one point the voice tells Chiniquy to "[b]reak the fetters, by which you are bound, as a vile slave, to the feet of such men!" (562)

64 And as if being bound to priestly feet or kept beneath sacred toes were not bad enough, the Roman slave must kiss the papal toe: "Kiss those holy toes" and "stop your upward flight!" (98). 
65 Chiniquy labels Newman's change to Catholicism a "perversion" not a conversion (204). Newman, "has played the .. traitor" (425) and fallen "into that sea of Sodom called Romanism" (417). ${ }^{65}$ Lest anyone think the noted Oxford professor has made an intellectually defensible decision in choosing to leave Anglicism for Catholicism, Chiniquy, using Orientalist language, charges Newman with believing and practicing both "superstition" and "idolatry" that are "below that of the Siamese. . . . The elephantgod of the Asiatic people, is infinitely more respectable than the wafer-god of Dr. Newman" (428-29).

${ }^{66}$ How can you trust someone who (though no longer) has at one time been an active agent for Babylon? Chiniquy himself acknowledges the challenges of having willingly participated in a system that he himself has portrayed at length and in depth as pagan, dishonest, conspiratorial, superstitious, immoral, and anti-intellectual: "I have often been asked, 'Was it possible that you sincerely believed that the wafer could be changed into God by you?' And, 'Have you really worshipped that wafer as your Saviour?'” (emphasis mine, 168). He responds, “To my shame, ... I must say 'Yes.' I believed as sincerely as every Roman Catholic priest is bound to believe it." If Catholicism was superstitious, shallow, showy, servile, and sexually suspect, how could any thinking person, any man (and gender matters here) ever be a part of it?

${ }^{67}$ For Chiniquy, the same cannot be said for Protestant adults who in any way fraternize with his Roman enemy. He compares those who educate their children in Catholic schools to "Pagan[s]" "slaying their children upon the altars of their gods" (86), lambasting them as "disguised infidel[s]," "hypocrite[s]" (88), and "so-called Protestants" (671) who have "no religion" (785). And Chiniquy laments over any who leave Wittenberg for Rome, speaking of those he helped persuade "during my twentyfive years of priesthood" as having "give[n] up their gospel light and truth, in order to follow the dark and lying traditions of Rome" (290); hence, theirs are not "conversions" but "perversions."

68 The autobiographical section of Slattery's Secrets of Romish Priests Exposed also largely places his Catholicism in a foreign land - the Ireland of Slattery's birth. In contrast to Chiniquy, Slattery is converted to Protestantism while still in Ireland (61). However, he leaves Ireland for the United States, and within a few months has been baptized in a Baptist church (64).

${ }^{69}$ One older cleric tells Chiniquy, "the Protestants are waiting for their opportunity to spread the Bible among our people. The only barrier we can oppose to that danger is to have in the future, as in the past, only a very limited number of people who can read or write. For as soon as the common people are able to read, they will, like Adam and Eve, taste the forbidden fruit; they will read the Bible, turn Protestant, and be lost for time and eternity" (379). Chiniquy acknowledges that most Canadian priests have the same fear, but his "views are absolutely different."

70 On the relationship between Protestantism, Catholicism, and literacy, see Mattingly.

71 When Father Mathew arrived in Boston (July 1849), he was greeted by a group of prominent Protestants, including the famously anti-Catholic Lyman Beecher (John F. Quinn, "'The Nation's Guest?"” 33).

72 Alphonsus Maria de Ligouri (1696-1787), a Catholic saint and doctor of the church, was a favorite Catholic writer for Chiniquy and other anti-Catholics to quote. 
73 " [t] $\mathrm{t}$ he priests, without a single exception, laughed at me, turned my plans into ridicule, and requested me . . . never to speak any more to them of giving up their social glass of wine" (341).

${ }^{74}$ At the same time, Catholic defenders would paint the ex-priests as having a problem with alcohol. See (1912) Defamers of the Church: Their Character's allegations of drunkenness and intemperance by ex-priests Seguin, Slattery, and Fresenborg. 75 In one place, Chiniquy puts drunkenness in opposition to "manly" virtues. When Catholic schools take over, "you may confidently expect that the self-respect and the manly virtue of the people will soon disappear - intelligence, progress, prosperity will soon wane away, to be replaced by superstition, idleness, drunkenness, Sabbathbreaking, ignorance, poverty and degradation of every kind" (74 emphasis mine). 76 "two feelings were at war in my mind. . . I rejoiced in the thought that I would soon have full possession of Jesus Christ, but at the same time I was troubled and humbled by the absurdity [the doctrine of transubstantiation] which I had to believe" (62).

${ }^{77}$ Chiniquy may have sincerely believed; but he sincerely believed in opposition to his own reasoning, as in the case of transubstantiation, "all the time, my eyes, my hands, my mouth, my tongue, my reason told me that what I was eating was only bread!" (61). ${ }^{78}$ Chiniquy does not leave the church at this point. In the end of this chapter he describes his battle against his conscience and reason to remain a Catholic (139-40). ${ }^{79}$ Interestingly, with the repetition of one adjective and a slight change in punctuation, the Irish bishop of Illinois (O'Regan) will later use the exact same language: "This is sheer Protestantism, Mr. Chiniquy, this is sheer Protestantism" (615).

80 Bishop O'Regan states (after "striking his fist on ... [a] table") that Chiniquy is "half a Protestant! Your words smell Protestantism! The Gospel! The Gospel!! That is your great tower of strength against the laws and regulations of our holy church!" (622).

81 Fresenborg's book is available here: http://archive.org/details/thirtyyearsinhel18040gut

${ }^{82}$ Chiniquy's Fifty Years, though, does give significantly more space both to his biography in general and his conversion in particular. Chiniquy's book is an autobiography told with a polemic purpose, including some chapters that are polemical without being autobiographical. In contrast, Slattery, Seguin, and Fresonberg's books are largely polemical with some biography included.

83 Fresenberg's work is available as an ebook, and citations are based on the iBook: opening line in Chapter Two; iBook 26/249.

${ }^{84}$ In his preface, Slattery basically issues a call to arms, reminding readers of the blood shed by Protestants of the past and calling on his audience to "bear aloft the banner of free men" (ix). The frontispiece for Out of Hell and Purgatory features a photograph of seventy-two-year-old Seguin, and is captioned, "Still on the battlefield for God and humanity"; indeed, the title page describes the book as "The Most Powerful Blow Ever Struck the Romish Hierarchy."

85 iBook 42/249;

http://www.gutenberg.org/catalog/world/readfile?pageno $=22 \& \mathrm{fk}$ files $=1510622$

86 Chiniquy exceeds them all, though, in claims and descriptions of persecution.

87 iBook 17/249

88 iBook 23/249 
$89 \mathrm{iBook} 16 / 249$. Although his title might lead a reader to expect more of an autobiography, Fresenborg's book has very little autobiographical information, with most of it found in the first chapter. The fifty-seven-year-old claims to have been out of the Catholic Church for less than a year at the time of writing (chapter 1; iBook 23/249).

90 iBook $6 / 249$

91 https://www.facebook.com/davidicke/info

$92 \mathrm{http}: / /$ www.davidickebooks.co.uk/index.php?act=viewDoc\&docId=6

$93 \mathrm{http}: / / w w w . d a v i d i c k e b o o k s . c o . u k / i n d e x . p h p ? a c t=v i e w D o c \& d o c I d=1$

94 Another possible use of a visionary ethos would be UFO abduction stories that rely on hypnosis to bring back suppressed memories. Granted, alien probing narratives are not necessarily conspiratorial. But they can form part of a conspiratorial plot where the government or some secret organization covers up their knowledge of an alien presence. 
CHAPTER THREE: MAKING ANTI-CATHOLICISM CREDIBLE VIA THE MEMORY OF A MURDERED PRESIDENT_THE ETHOS OF ASSOCIATION, APPROPRIATION, AND ASSASSINATION

\section{A Murdered President in American Memory}

For those in post-Civil War America, the tragic murder of Lincoln ingrained itself into their psyche and memory much as the Japanese attack on Pearl Harbor or the assassination of President Kennedy or the attack on the World Trade Center would do with coming generations; in this sense, Lincoln's assassination was their 9/11.

“Lincoln's death,” writes Merrill D. Peterson in his 1994 Lincoln in American Memory, "sank into the hearts and captivated the minds of the generation that grew to maturity after the Civil War" (5). Jane Addams, who was not yet five in April 1865, remembered American flags hanging on the gate posts outside her family's home and the weeping grief of her father: "The two flags, my father's tears and his impassioned statement that the greatest man in the world had died, constituted my initiation . . . into the thrilling and solemn interests of a world lying outside the two white gate posts" (23). The death of a president while in office would be shocking at any time. But the means and moment of Lincoln's death served to amplify its impact. At the end of a bloody war, with victory won and the union preserved, during the holiest weekend of the Christian calendar, the great emancipator was attacked with an assassin's bullet. "Father Abraham," as he was sometimes called, was shot on Good Friday's eve and died 
on Holy Saturday morn. A deeply religious nation entered their churches that Easter to mourn the death of their national savior. Across at least the northern half of the country, ministers scrambled to change sermons to speak to the crisis. Katherine Lee Bates, author of the words to "America the Beautiful," later wrote the poem "When Lincoln Died," which captured the theodicy facing a nation without its president: "And not one angel to catch the bullet! / What had become of God?" (qtd. in Peterson 6). "It would be remembered," Peterson writes, "as Black Easter" (7). ${ }^{1}$ But in the events of that weekend lay not only a nation's grief but also the basis for Lincoln's apotheosis.

Upon his death, Lincoln rose in the American cultural psyche to heights equal to or surpassing perhaps any other national hero. The end of slavery, the preservation of the union, the dramatic nature and timing of his death, along with his mythic and humble rise from poverty to the White House, all combined to ensure Lincoln a place in the American pantheon. Peterson describes five "guiding" and "resilient" themes that have, over the generations, formed how Americans remember Lincoln (35): he is "Savior of the Union, Great Emancipator, Man of the People, the First American, and the Self-made Man," embodying our sense of "Nationality, Humanity, Democracy, Americanism, and the individual opportunity." For Americans, Lincoln became "a national treasure to be preserved, loved, revered, and emulated" (34), a sense of awe captured in Episcopal minister Phillips Brooks' exhortation to his congregation concerning the recently deceased chief executive, "May God make us worthy of the memory of Abraham Lincoln" (qtd. in Peterson 35). 
In this chapter I explore how the memory—and ethos—of Lincoln was used to provide credibility to the anti-Catholic movement. I examine how both an alleged Catholic conspiracy against the president and a president who alleges a Catholic conspiracy against him — and the Union — were constructed in Fifty Years to promote an anti-Catholic message. In the previous chapter, I looked at how the overall narrative of Fifty Years constructs an ethos for Chiniquy that would allow his argument against the Catholic Church, in particular his conspiracy charges, to be persuasive to an audience open to the anti-Catholic message. In this chapter, I narrow my focus from the book as a whole to the section (chapters 56-61) that deals specifically with the purported Lincoln/Chiniquy friendship and Lincoln's alleged conspiracy charges against the Church. My reading of Fifty Years leads to me to see three types of ethos construction at work in the text: association, appropriation, and assassination. While these constructions have not been foregrounded in ethos scholarship, all of them, I argue, contribute to understanding, not only conspiracy rhetoric in particular, but also the nature of ethos in public rhetoric in general.

I first examine how the text constructs creates Chiniquy as an intimate friend of Lincoln, which serves as a powerful means of creating ethos, especially during the postCivil War era. I am here arguing for an ethos by association, in which a rhetor gains credibility for extreme claims by associating with another person regarded as eminently trustworthy. Second, I consider the theme of Lincoln as an enemy of Catholicism. Fifty Years places the case against the Catholic Church in the mouth of the sixteenth president. In so doing, it brings in a witness of great import, situating Chiniquy's case on the ethos of Lincoln. This rhetorical move, I am arguing, is an ethos by 
appropriation: the anti-Catholic movement appropriates Lincoln, taps into the power of his character, giving it and its conspiracy message greater credibility. Associative and appropriative rhetoric serve as potentially powerful tools, allowing speakers and authors the opportunity to elevate themselves and their messages — key goals in public rhetoric. As such, both the ethos of association and appropriation deserve greater scholarly attention. Both serve theorists as powerful heuristics, raising questions about how rhetors see themselves and those with whom they wish to be connected. Additionally, both remind us that ethos is not something entirely individual and private. Instead, ethos is relational, social, and connected to others - it involves association with and appropriation of others. Third, I examine how the text constructs the Catholic Church as the enemy of Abraham Lincoln and the American republic. Vilifying the Catholic Church demonstrates a significant move in ethos construction: ethos is not always positive, and when constructed by one's opponents, it can become negative. ${ }^{2}$ Here I am arguing for ethos by character assassination. I examine political assassination as a conspiracy trope, demonstrating its usefulness in constructing an enemy as dangerous to the body politic. This chapter, thus, contributes to our understanding of ethos in conspiracy argument, including its use as an offensive weapon: an effective conspiracy allegation depends not only the construction of the rhetor's ethos, but also the degradation of the opponent's ethos.

In this chapter and this dissertation as a whole, I am seeking to problematize a perhaps popular assumption that ethos is a positive - that if one has ethos, one has something that is good. ${ }^{3}$ To tell someone that they have a good or a strong ethos is to pay him or her a compliment, and historically there has been a connection between the 
rhetorical proof of ethos and the ethical and moralistic quality of personal character, integrity, and honorable reputation. " ${ }^{4}$ "Throughout the history of rhetorical theory," writes Nan Johnson, " ethos has been defined in one of two ways: as a mode of persuasion that relies on the prerequisite virtue of the speaker; or as a mode of persuasion that relies on the speaker creating a credible character" (243). As Johnson's description shows, ethos has typically been connected to both "virtue" and "credibility," words with strongly positive connotations. Neither would be assigned to Adolf Hitler, and yet it would be hard to disagree with the idea that he constructed a successful ethos among his target audience. Though he found Mein Kampf "exasperating, even nauseating," in "The Rhetoric of Hitler's 'Battle”" (first published in 1939), Kenneth Burke reminds his audience that Hitler is a "man who swung a great people into his wake" (191). ${ }^{5}$ Though his message and his means of getting across his message were neither virtuous nor credible, ${ }^{6}$ he still created an ethos that resonated with millions of Germans, enough for him to lead them into a disastrous world war (see Steven B. Katz's [1992] “The Ethic of Expediency: Classical Rhetoric, Technology, and the Holocaust"). ${ }^{7}$ Indeed, perhaps the popular understanding of ethos as a good stems, at least in part, from its being frequently equating with ethics. ${ }^{8}$ George E. Yoos (1979) writes, "Traditionally in rhetoric there has been a mix-up between the concepts of ethos and ethical appeal" (41), and criticizes how the have been "too readily assimilated" (48). Yoos proposes a "redefinition of the ethical appeal grounded in moral terms" and a separation of "the concept of ethical appeal from the concept of ethos" $(41,49){ }^{9}$ When ethos equals ethics, when ethos becomes the ethical argument, it may be difficult to view someone whose message is ethically challenged as having ethos. ${ }^{10}$ This 
potential connotational conundrum is true when ethos is understood as personal character or persuasive credibility. If ethos is personal character, then it may be hard to see someone as having ethos whose message lacks character as we define character, as for instance when someone with hate speech persuades his or her audience. And if ethos is credibility, then how can someone who promotes a message deemed "paranoid" or "fringe" or worse, such as those who promote conspiracy theories, be viewed as credible? Their message isn't, so how can they be $?^{11}$

I am, however, arguing that ethos is not restricted to the ethical, the moral, and the good: good people who convey good messages have a good ethos. My project reminds us that just as the concept of a "good" can be socially constructed, so one can successfully construct an effective ethos for what might otherwise be seen as an ethically problematic message. Ethos is a transaction between rhetor and audience. And a person with an intolerant message, like Chiniquy (who serves as a valuable case study into the power of ethos used for negative purposes), can establish an ethos that successfully connects with an intolerant audience, such as nativists and anti-Catholics have done since the latter days of the nineteenth century up into the present. The popularization and promulgation of the Chiniquy message illustrates a tension between ethos and ethics. And it does so via the constructed (or misconstructed) memory - and ethos-of Abraham Lincoln.

\section{Chiniquy, Friend of Lincoln: Ethos by Association}

For Charles Chiniquy, Abraham Lincoln was "the most devoted and noblest friend I ever had" (661); and for Chiniquy's Lincoln, there was no one quite like Chiniquy, upon whose "devotedness" he "could better rely" (692). When it came to the 
Catholic conspiracy against the Union, Chiniquy was, for Lincoln, "almost the only one with whom I speak freely on that subject" (715). Fifty Years thus pictures Chiniquy as the intimate friend of the martyred president, a comrade in arms against a Catholic foe. This ethos-by-association construction of Chiniquy as friend of Lincoln was a powerful means of establishing a credible and trustworthy character, especially during the postCivil War era. When ethos is created by association, a rhetor gains credibility for his message and his movement by associating himself with another person regarded as eminently trustworthy. ${ }^{12}$ Chiniquy associates himself with Lincoln in order to associate Lincoln with Chiniquy: the nation's greatest president and national savior had Chiniquy as his friend. Associative ethos raises questions about who a rhetor wishes to be associated with - and why. What are the benefits of associating with a particular person, or, at least, an image/myth associated with that person? Rhetors, of course, do not want to be associated with anyone and everyone - no one in mainstream American political and popular discourse wants to be connected to Adolph Hitler. But they do wish to be associated with others. And Americans still wish to be connected to Abraham Lincoln. During his acceptance speech (September 6, 2012) at the Democratic National Convention (Charlotte, North Carolina), President Obama quoted the sixteenth president twice, telling the crowd that from his experience he knew "exactly what Lincoln meant” (“Transcript: President Obama's Convention Speech”). ${ }^{13}$ As effective as it may be to align one's experience with another, when it comes to the ethos of association, the closer the connection the better. Consider Senator Lloyd Bentsen's famous retort to Senator Dan Quayle during a 1988 vice-presidential debate: "Senator, I served with Jack Kennedy. I knew Jack Kennedy. Jack Kennedy was a friend of mine. 
Senator, you're no Jack Kennedy” (M. J. Stephey “Top 10 Memorable Debate Moments"). ${ }^{14}$ Chiniquy's alleged intimate association with Lincoln is one of the reasons that his narrative has had such staying power: he quoted the martyred president with whom he was a devoted friend.

Chiniquy's tale and ethos of association with Lincoln begins years before the war and the presidency. His alleged friendship with Lincoln and Lincoln's allegations of a Catholic conspiracy against him supposedly start in an antebellum Illinois courtroom. A disgruntled parishioner's (Peter Spink) claim that the then-priest had slandered him led to a series of courtroom appearances (1855-1856) which eventually caused Chiniquy to engage Lincoln as his lawyer. Spink was a devout Catholic and a fellow French Canadian immigrant to Illinois with whom Chiniquy had lived with for a period of time and from whom Chiniquy bought land (Lougheed 66, 69). Their relationship soured, and Spink took Chiniquy to court, claiming that the priest had slandered him in public, accusing Spink of dishonesty concerning land sales, injuring his business (George 23-24; Lougheed 73). Ultimately, the case was moved to Urbana, Illinois, with Lincoln as Chiniquy's attorney. This was not Lincoln's first slander case. ${ }^{15}$ Mark E. Steiner (1995) describes Lincoln's work with accusations of slander as evidencing a disposition to be a "peacemaker": "His slander cases show that he often took advantage of opportunities for mediation and compromise" (1). Indeed, this attempt to make peace between parties and avoid litigation (or mitigate potential harmful results) was a common practice among antebellum attorneys, who "in general, and Lincoln in particular, did not want to resolve all disputes with formal adjudication" 
(2). In notes for a lecture on the law, Lincoln wrote, "Discourage litigation. Persuade your neighbors to compromise whenever you can. Point out to them how the nominal winner is often a real loser-in fees, expenses, and waste of time" (qtd. in Steiner 2). According to Henry Clay Whitney (1892), who lived in Urbana and was Lincoln's friend and fellow lawyer, Lincoln "abhorred that class of litigation . . . and used his utmost influence with all parties [in the Chiniquy/Spink case], and finally effected a compromise" (55). ${ }^{16}$ Spink and Chiniquy divided court costs and the case was dismissed (Steiner 16). ${ }^{17}$ Although the case was a minor moment in Lincoln's legal career, it benefitted Chiniquy's ethos by associating him with Lincoln the wise, eloquent lawyer, who passionately pursues justice: if Chiniquy is a man that Lincoln would vindicate, then he must be a man worth defending. But the charges contained within Fifty Years also benefit, for this dismissed case becomes, in Chiniquy's telling, a Catholic plot against Chiniquy and the inciting incident in the Church's plot against Lincoln — the incident that will lead to Lincoln's assassination.

Whether Chiniquy actually committed slander, Fifty Years has nothing good to say about Spink, connecting his litigation to a bishop intent on destroying Chiniquy and the results of his lawsuit to Jesuits bent on killing Lincoln. ${ }^{18}$ A stranger tells Chiniquy, "Spink is only an instrument in the hands of" Bishop O'Regan, a Chicago-based superior with whom Chiniquy had a problematic relationship (624). But in upsetting one, Chiniquy has angered all bishops: "when you fight a bishop," states the stranger, “you fight all the bishops of the world." Chiniquy’s hope rests in securing Lincoln: "If that man defends you, you will surely come out victorious from the deadly conflict," which in Fifty Years, he does. In Chiniquy's narrative no case is dismissed with court 
costs split but rather a great victory takes place for Chiniquy—Lincoln even tells him that Spink and a priest who had testified against him are being targeted by a mob for lynching $(659,661,664)$. However, in Fifty Years this victory comes at the price of Lincoln's life. In Chiniquy's recounting, the slander suit ends with Spink admitting Chiniquy's innocence, and Lincoln "denounc[ing] the rascality of the priests who had perjured themselves," "making the walls of the court-house tremble under the ... superhumanly eloquent denunciation of their infamy" $(661,664)$. Lincoln's thwarting the bishop's plot along with his closing harangue makes him a target, for in the crowd there were "not less than ten or twelve Jesuits" who had come to see Chiniquy condemned to jail (664). Denied their wish, infuriated by Lincoln's eloquence, the Jesuits, Chiniquy insists, sentence Lincoln to death. When told this, Lincoln acknowledges, "Jesuits never forget nor forsake."

According to Chiniquy, Lincoln defends Chiniquy not out of (or solely because of) a legal obligation to faithfully represent his client: he defends him, and in so doing puts his own life on the line, because they are friends. When the soon-to-be ex-priest tries to settle his legal bill, the soon-to-be president initially dismisses any thought of payment, stating that he has defended him "less as a lawyer than as a friend," expressing his "hope" that he has "the right to be put among the most sincere and devoted of your friends" (662). Though the two eventually settle on a fee of $\$ 50$, the trial will cost Lincoln much more: Chiniquy has a "presentiment" that Lincoln "would pay with his life what he had done for me" $(663-64) .{ }^{19}$ Lincoln here becomes the ultimate friend and a Christ figure: he is willing to lay down his life for another. By describing him in such noble terms, the text elevates Lincoln, but it also elevates 
Chiniquy: he is the object of Lincoln's sacrifice, the real cause for Booth's eventual assassination. Lincoln, the martyr president, dies for Chiniquy, the president's friend. The text thus creates a strong and early association between the two men. While not a childhood friend, Chiniquy is no latecomer to a relationship with the president; the two men, who were the same age, knew each other years before the war. And by warring against the Jesuits, with life and death at stake, the two have had a friendship, in effect, born of battle. They are not only friends, they are comrades in arms - an important symbolic union that will help make the move from an ethos association to that of appropriation.

The friendship begun in an Illinois courtroom continues on to the Lincoln White House, thus uniting Chiniquy not only with Honest Abe, the wise lawyer, but also with Father Abraham, the savior of the union. Father Chiniquy alleges that he made three visits to President Lincoln in the White House (August 1861, June 1862, June 1864). These visits are represented as evidence of intimacy between the two, in which both confide in each other concerning the Catholic Church and its plots against the Union and the man who would save it. The descriptions of the visits also evoke ethos constructions that I previously described in my second chapter, in particular the ethos of victim and that of patriot. A mingling of these constructions can be seen in Chiniquy's first visit, early in the Civil War (August 1861). Having heard from a recently converted priest that there was an assassination plot afoot $(691,694)$, Chiniquy visits Washington D.C. to warn Lincoln. The president, glad to see his friend, offers him a job as secretary to the ambassador to France so that he might spy on the Catholic Church. "I do not know any man in the United States," states Lincoln, "so well acquainted as you are with 
the tricks of the Jesuits, and on the devotedness of whom I could rely" (692). Chiniquy declines, citing his need to continue attempting to convert French Canadian Catholic immigrants to Protestantism. Though he will not serve as Lincoln's secretary, he will serve as his teacher, explaining why Democratic-leaning newspapers in the north have published stories that Lincoln had been born and baptized a Roman Catholic (which Lincoln wasn't). According to Chiniquy, if Lincoln had been a Catholic and he left the Church, then he would be viewed by Catholics as an apostate, excommunicated, and under the sentence of death: "in the Church of Rome, an apostate ... has no right to live" (694). Thus warned, Lincoln, now, too, has a "presentiment that God will call me to him through the hand of an assassin" (695). Although Lincoln will fall victim to a Catholic bullet, by claiming to have warned the man in Washington who had saved his life in Illinois, Chiniquy has proven himself not only the friend of the president but also the friend of the republic.

Written in the 1880s, Chiniquy's memorial account of Lincoln was published while the nation was on its way to being "awash in Lincoln memory and reminiscence" (Peterson 83). Horace Greeley (1811-1872), the famed editor, began his lecture on Lincoln describing the widespread dissemination of Lincoln stories: "There have been ten thousand attempts at the life of Abraham Lincoln, whereof that of Wilkes Booth was perhaps the most atrocious; yet it stands by no means alone" (Greeley 11 ). ${ }^{20}$ Although the "tide of reminiscence rose slowly after Lincoln's death, [it] became a flood in the 1880s, and crested at the centennial of his birth in 1909" (Peterson 85). "Almost anyone," writes Peterson, "who had encountered Lincoln in a significant way felt 
compelled sooner or later to tell about it" (86). There was a definite market for memories, including books, magazine articles, memorabilia, and a Lincoln lecture circuit $(86-87,138)$. Don E. Fehrenbacher and Virginia Fehrenbacher (1996) add that "[r]ecollective writing about Lincoln was at least partly a pursuit of recognition and, to a more limited extent, of financial gain. Associating oneself in print with the great man of the age could scarcely be anything but nourishing for one's self-esteem and reputation" (xlix). This corpus of memories "reflected the people's fascination with Lincoln's character" (Peterson 84). Indeed, as Ronald C. White, Jr., (2009) writes, ethos was at the heart of his appeal: "Lincoln may not have read ... Aristotle's Treatise on Rhetoric, but he embodied his definition" (6). People trusted Lincoln. They wanted to know more about him, to connect with him, to learn from him, and perhaps even to become like him. In this apotheosis, Lincoln had become the American hero, a man worthy of near worship. In this historical context, to claim a close association, a friendship with the great emancipator provided a potentially powerful rhetorical advantage.

There were, however, problems with many of the memories. ${ }^{21}$ In a note (December 20,1859) accompanying a notoriously brief autobiography (only a few hundred words in length), Lincoln requested, "If anything be made out of it, I wish it to be modest, and not to go beyond the material" (Abraham Lincoln: Complete Works, Comprising His Speeches, State Papers, and Miscellaneous Writings 596); in the flood of reminiscences, his request was not granted. ${ }^{22}$ Lincoln was exalted but was also changed in the reminiscences, at times reflecting the desires and interests of the one remembering. For instance, Edward Steers, Jr., (2007) describes the multiple, 
conflicting accounts of Lincoln undergoing a secret baptism to the Christian faith. If the reports were true, Lincoln experienced a covert conversion via a Baptist or a Dunkard (German Baptist) or a Disciples of Christ minister — there are, as Steers remarks, "too many ministers with their hands in the water" (78). Peterson describes the nature of reminiscence as "the recollection of past persons and events largely without benefit of historical documents" (83). As such, its accuracy rests upon the one doing the recollecting, and the process of reminiscing depends upon a slew of complex variables and problems. "[M]emory fades," writes Peterson, and "is subject to tricks: of vanity and conceit, of partiality, error, and displacement." Even the most honest of storytellers is still subject to the caprices and vagaries of memory. The mind does not capture the past with the precision of a photograph, and "[r]eminiscence, as the product of memory, is not simply imprinted but constructed by the mind" (84). In the days following Lincoln's death, a good number of people remembered a good number of memories, not all of which can be viewed as true. There was a continuum of accuracy: "The quality of truth in the reminiscences ranged from the instantly credible through the reasonable or plausible to the implausible and downright unbelievable" (88). ${ }^{23}$ And it is with the latter that Peterson places Chiniquy's memories, reminiscences he describes as “truly sinister" and "wicked testimony" $(92,338)$.

Aside from Chiniquy's own claims, there is little evidence to support his claim to a friendship with Lincoln. There is no correspondence from Lincoln to Chiniquy, and the two letters from Chiniquy to President Lincoln have a tone that does not suggest intimacy between the two (see George 24-25). Whitney's account of the 1856 Urbana 
trials says nothing about Jesuit involvement or plotting, but describes it as a slander case, and a "tedious" one at that (55). Perhaps the only potentially substantive piece of corroborating evidence would be a note from Lincoln's eldest son, Robert Todd Lincoln, to Chiniquy. The ex-priest had sent him a copy of Fifty Years with a brief note (September 7, 1885) stating in part that his "father was the dearest and most sincere friend God ever gave me" (Chiniquy to Robert Lincoln). ${ }^{24}$ A few days later (September 10, 1885), Robert Lincoln replied: "My Dear Sir: I beg you to accept my thanks for sending your book and especially for the expression you use in your note in regards to my father. He made many friends in his life but plainly, none more warm than yourself. ${ }^{25}$ Most sincerely yours, Robert Lincoln" (Letter to Charles Chiniquy). This has been taken by some as an acknowledgement by Robert Lincoln of a deep friendship between his father and Chiniquy (see Paul Serup's 2009 Who Killed Abraham Lincoln?: An Investigation of North America's Most Famous Ex-Priest's Assertion That the Roman Catholic Church Was Behind the Assassination of America's Greatest President). However, Jason Emerson, leading Robert Lincoln scholar, describes the letter's language as “typical of RTL's responses to all letter writers -- he would thank them and make them believe they were correct in their assumptions without really himself taking a stand either way" (personal correspondence, August 3, 2013). ${ }^{26}$ Emerson goes on to suggest that Lincoln's response to Chiniquy was indicative of his cultural training and background: "Robert was a quintessential Victorian gentleman, and he rarely ever openly disagreed or challenged people in their personal beliefs on his father. ${ }^{27}$ 
Regardless of the lack of corroborating evidence, the Chiniquy claim found a home among its anti-Catholic audience. As will be seen in my next chapter, Chiniquy's claim to be a friend of the president would be attached to the anti-Catholic literature used to convey his message of a traitorous and murderous church. In so doing it tapped into the power of Lincoln's ethos and his memory, which both illustrates Lincoln's ongoing rhetorical usefulness and the process by which it was constructed. As Don Fehrenbacher and Virginia Fehrenbacher state, "“the legendary Lincoln, created in part out of dubious recollected material, may have been, in the long run, as powerful an influence in American life as the historical Lincoln" (liii). In the service of ethos, memory becomes a rhetorical act, constructed not only to remember but also to persuade. In the hands of a rhetor like Chiniquy, the alleged personal memories of a past president become the means of a powerful ethos construction for a public audience. Indeed, the ethos of association becomes a powerful tool for a variety of rhetorical situations: those who promote a marginalized message, such as conspiracy narratives that are labeled paranoid or products of the fringe, gain a level of credibility by association with a trusted personality, living or dead. And this credibility can help mainstream their claims. An ethos of association can be seen, for instance, when proponents of a conspiracy theory associate their message with expert authorities. ${ }^{28}$ For instance, the 9/11 Truther movement benefits from associating its narrative(s) with academic scholars, such as Dr. David Ray Griffin (Claremont Graduate University), Dr. Steven Jones (Brigham Young University), and the Scholars for 9/11 Truth and Justice. ${ }^{29}$ In his critique of the Truther movement, Jonathan Kay (2011) writes of Richard Gage, who became a 9/11 revisionist in part due to hearing a talk by Griffin on 
the radio (154). Gage, an architect, helped found the Architects and Engineers for 9/11 Truth. According to Key, "[t]hanks to his bookish style and suit-and-tie wardrobe, Gage has become a unique property among Truthers: a quasi-respectable media pundit" (152). Kay describes the hearing the architect—and his message_- has received: "In recent years, he's [Gage] been featured in mainstream documentaries, and spoken at the Commonwealth Club. Some local television stations have broadcast the film version of his slideshow Blueprint for Truth. Colorado Public Television (KBDI-TV/12) even featured it during a 2009 fundraising drive.”

The popularity of the Chiniquy conspiracy among anti-Catholics illustrates the rhetorical power and the allure of ethos by association, especially close association. Other ex-priests and former nuns made negative claims against the Catholic Church, but none claimed friendship with the central hero of America's self-defining civil war. It is this ethos by association, I am arguing, that helped make Chiniquy's charge popular among anti-Catholics and has helped keep his work in print since the late $1800 \mathrm{~s}$. Chiniquy helps establish his ethos here due to his relationship with Abraham Lincoln: believe in me because you believe in him. But this ethos by association also encourages an ethos of appropriation, which I will examine in the next section. For by associating himself with Lincoln, Chiniquy can appropriate the president not only for himself but also for his anti-Catholic movement and message.

\section{Lincoln, Enemy of Catholicism: the Ethos of Appropriation}

In a 1908 speech to the Illinois State Historical Society, the journalist and friend of Lincoln, Horace White described "the daily citation of Lincoln's name and authority" 
in the discourse of the time (725). "His sayings," writes White, "are common property [,] . . quoted as freely by Democrats as by Republicans.” Speaking just a year shy of the centennial of Lincoln's birth, White declares, "he is more quoted today than he was in his lifetime, and more than any other American ever was." "A quotation from him," White states, "is a knock-down argument."30

Since his death, Lincoln has been adopted by different, even opposing, causes. His "quotes have been used by management, labor, free traders, protectionists, wets, drys, and sundry others to prop up their causes" (Ralph Keyes 95). ${ }^{31}$ He has become, perhaps, America's most quoted president. But he has also become one of its most misquoted, with statements ascribed to him for which there is no substantial proof. ${ }^{32}$ Some misquotations have come about innocently, but others appear to have been purposely generated to advance a position. For instance, a Gilded Age antiprohibitionist claimed that Lincoln (a teetotaler) proscribed prohibition as "a species of intemperance within itself' (Boller and George 80). The frequency with which Lincoln is quoted and misquoted points to the power of his ethos: people listen to him simply because he is Lincoln. Whether or not Lincoln is right often does not even enter the argument. For some, Lincoln said it (perhaps), they believe it, and that settles it. Thus, to appropriate Lincoln for one's cause can be a profoundly rhetorically savvy movethis is the power of the ethos of appropriation.

There are similarities, of course, between ethos by association and that by appropriation. Both, for instance, are fundamentally about making a rhetorical connection between a speaker/author and another person. Both also point to the social nature of ethos: neither is individualistic but requires the presence of another. ${ }^{33}$ Yet they 
are also distinct. A speaker or author can engage in one without the other-one could claim an association with Lincoln without placing one's message in his mouth. And though they both deal with connections, they differ in the type of connections they make. Ethos by association focuses more on the messenger, adding stature to rhetors themselves (and then their message) by associating them with someone viewed as trustworthy (perhaps, more trustworthy): I am associated with him/her. Ethos by appropriation focuses more on the message, adding stature to a rhetor's message by having someone viewed as trustworthy (perhaps more trustworthy) speak the same message. In the ethos of association, a reader should trust Chiniquy because he is Lincoln's friend (whom you trust); in the ethos of appropriation, a reader should trust Chiniquy's message because Lincoln (whom you trust) said the same thing.

As was true with Chiniquy's ethos of association, the ethos of appropriation uses alleged personal and private memories as an ethos transaction for a public audience. In Fifty Years, Lincoln is Chiniquy's friend and his co-opponent against the Catholic Church: Lincoln likes Chiniquy, and he hates the Catholic Church. The text puts the case against the Church on the lips of the deceased president, thus connecting opposition to Catholicism to the ethos of America's savior president. Fifty Years thus acts in a way similar to other public memories - using the past to create a present. As Peterson writes, "The public remembrance of the past, as differentiated from the historical scholars', is concerned less with establishing its truth than with appropriating it for the present. ... [I]t restages the past and manipulates it for ongoing public purposes" (35). In Fifty Years, Chiniquy appropriates the ethos of Lincoln for his antiCatholic conspiracy message in multiple ways, but in this section I focus on two 
particular forms of appropriation. First, he has Lincoln state themes that were typical of Gilded Age anti-Catholic rhetoric. Second, he has Lincoln blame the Roman Catholic Church for the American Civil War, thus tapping into a powerful desire among post-war white Americans to reconcile with each other by forging a narrative that forgets black slavery. A narrative that blames the Civil War on a Catholic plot allows black slavery as causation for the war and white responsibility for black slavery to be forgotten. At the same time, it allows the focus of the war in American memory to shift from the emancipation of African Americans to imagined (largely) white slavery to a Catholic pope, thus shifting culpability for the war itself away from white Americans to a foreign (Roman) other.

\section{Lincoln: The Nineteenth-Century Anti-Catholic}

After excerpting from a Lincoln dialogue in Fifty Years, Lloyd Lewis remarks that for those "familiar with Lincoln's reticences, absence of orthodox Christian belief and characteristic manner of speech, these disclosures were far more Chiniquy than Lincoln" (299). ${ }^{34}$ Indeed, the Lincoln of Fifty Years sounds like Chiniquy, but he also sounds a great deal like a typical nineteenth-century anti-Catholic American, or as Peterson phrases it, Chiniquy “filled Lincoln's mouth with anti-Catholic slander" (93). For instance, during Chiniquy's alleged first visit to the president (August 1861), Lincoln supposedly condemns "the generality of the priests of Rome" for their "fierce hatred" toward "our institutions, our schools, our most sacred rights, and our so dearly bought liberties" (697). This type of statement appropriates typical Gilded Age antiCatholicism, which positioned the Catholic Church as opposed to each element 
mentioned in Lincoln's remark. Josiah Strong, for instance, in his Our Country: Its Possible Future and Its Present Crisis (1885), describes the Church as opposed to American public schools, free speech, free press, and freedom of conscience (46ff.). Similarly, in his 1876 The Papacy and the Civil Power, former Indiana congressman Richard W. Thompson characterizes the Catholic Church as opposed to American freedoms and institutions. ${ }^{35}$ Published by Harper \& Brothers, Papacy argues for an opposition between papal and American views on the role of the church in civil power, leading Thompson to accuse the current pope, Pius IX, of "endeavoring to break down the lines of separation between all the nations, and to resolve the world into one great 'Christian commonwealth' . . . subject to his single will, and bowing before his single scepter" (196). Catholicism, then, for Thompson, anti-Catholics, and Lincoln himself is not inimical to American nationalism, independence, or freedom. ${ }^{36}$

Raising worries about the survival of the American republic remains a trope in contemporary conspiracy rhetoric. In American Conspiracies, former governor of Minnesota Jesse Ventura (along with co-author Dick Russell) argues for a conspiratorial and revisionist view on several moments in American history, including the assassination of Kennedy (more than one shooter), as well as 9/11 ("The Bush Administration either knew about the plan and allowed it to proceed, or they had a hand in it themselves" [142]). In a chapter entitled "The Secret Plans to End American Democracy," Ventura warns, "Our Constitution and Bill of Rights have never been in greater peril than now. The technology exists to further erode our democracy, and basically make slaves of those who don't go along with the program" $(183) \cdot{ }^{37}$ As in the nineteenth century, so in the twenty first, the American republic is never safe. In 
conspiracy rhetoric, the United States is always just one "Manchurian Candidate" away from the end of democracy and the triumph of dictatorship. ${ }^{38}$

For Chiniquy's anti-Catholic Lincoln, Catholicism endangers the republic to the extent that the nation must reconsider the granting of constitutional rights to its practitioners. During Chiniquy's third visit (June 1864), Lincoln acknowledges a change of heart. Until recently, he had favored "the unlimited liberty of conscience" for Catholics as dictated by the constitution (705); however, he now saw that "sooner or later, the people will be forced to put a restriction to that clause towards the Papists." Catholic liberty must be limited due to Catholics' obedience to a system that claims for its leader "the power of life and death." This is the "supreme power," and within the confines of a nation, it cannot belong to both a pope and a president: "two supreme powers cannot exist on the same territory without anarchy, riots, bloodshed, and civil wars without end." Indeed, how can the nation give Catholics full freedom of conscience when "they tell me, through all their councils, theologians and canon laws, that their conscience orders them to burn my wife, strangle my children, and cut my throat when they find the opportunity!" Lincoln's words echo the oath attributed to the Knights of Columbus, which in fact was an anti-Catholic forgery, which had members of this Catholic society allegedly pledge full war on Protestants: "I do promise ... that I will hang, burn, waste, boil, flay, strangle, and bury alive those infamous heretics [Protestants and Masons]; rip up the stomachs and wombs of their women, and crush their infants' heads against the walls" (qtd. in Boller \& George 62). ${ }^{39}$

Chiniquy's Lincoln is willing not only to deny Catholics their constitutional right to worship but also, if need be, their lives - indeed, the level of violence expressed 
by Chiniquy's Lincoln towards Catholics is one of the most striking characteristics of the Fifty Years dialogues. During Chiniquy's first visit, Lincoln describes himself as understanding — and approving — the execution of priests that took place during the French Revolution. ${ }^{40}$ His experience as the commander in chief, in which "the immense majority of Roman Catholic bishops, priests and laymen, are rebels in heart, when they cannot be in fact," had given him sympathy with the patriots of the French Revolution. Lincoln (who in reality frequently canceled orders of execution against Union soldiers accused of desertion out of a sense of compassion) understands how the French, in order to see the "colors of Liberty" fly over the nation, "were forced to hang or shoot almost all the priests and monks as the irreconcilable enemies of Liberty." After describing "every priest and every true Roman Catholic" as a "determined enemy of liberty," Lincoln makes an approving reference to the excesses of the French Revolution (697). "Their extermination, in France," he states, "was one of those terrible necessities which no human wisdom could avoid." Although a "terrible" act, it is not only the product of "human wisdom" but also of divine providence: "it looks to me now as an order from heaven to save France." His mention of the divine leads to a supplication that "the same terrible necessity be never felt in the United States!" And yet, if it were, would the great emancipator become America's Robespierre?

\section{Lincoln: The Anti-Catholic Civil War Historian}

Fifty Years appropriates Lincoln as a spokesman for anti-Catholic rhetoric not only by having him state common anti-Catholic themes and arguments but also by placing on his lips a narrative with strong rhetorical potential in a nation still framing an understanding of its most destructive war. This was a war in which white Americans 
fought white Americans over the enslavement of African Americans. In the post-war period, however, emancipation and full citizenship for black citizens (many of whom had also served in the Union army) gave way to Jim Crow, and white Americans sought to forge a union that would never divide again by, in part, forgetting (or segregating) the freed blacks. By 1877, as historian Jackson Lears (2009) remarks, "In public discourse, the primary meaning of the war became Reunion, not Emancipation" (22). David W. Blight (2001) describes three overarching narratives concerning the Civil War's meaning that formed in the nation's memory: the reconciliationist, white supremacist, and emancipationist visions (2). Akin to Lears, Blight argues, "the forces of reconciliation overwhelmed the emancipationist vision in the national culture," with the "inexorable drive for union both us[ing] and trump[ing] race." There was in the postbellum nation a "politics of forgetting" (45), which allowed slavery—and freed people - to be forgotten and masculine, white sacrifice to be honored. Chiniquy, while characteristically blaming Rome, does acknowledge the role black slavery played in the war $(690-91,707,712,715)$. However, in Fifty Years the Civil War becomes not a battle over states rights, the union's continuation, or the slaves' freedom; rather, the war-according to Chiniquy's Lincoln — is a Vatican plot to destroy the American republic: "it is to Popery that we owe this terrible civil war" (714). Lincoln describes the pre-war division over slavery as one in which there "great differences of opinion," and yet, he adds, "neither Jeff Davis nor any one of the leading men of the Confederacy" would have attacked without Catholic aid (699). And the war that the Catholics began, they also sustain: Lincoln ascribes newspaper attacks against him (693-94), the 1863 New York draft riots (703), and the alleged papal recognition of the 
Confederacy (700-702) to nefarious Catholic influence—-he even accuses General George Meade (1815-1872), Union commander at the pivotal battle of Gettysburg, of not pursuing the retreating Lee after a brief meeting with a "disguised Jesuit" (702).

In the post-war United States, Chiniquy's anti-Catholic narrative had great rhetorical potential. Besides choosing Lincoln as its spokesman, it also allowed southern and northern whites another means by which to forget black slavery as a cause for the civil war by focusing on Catholic "slavery," which would have largely been white. Indeed, anti-Catholic rhetors at times argued that Catholic slavery was worse than black slavery—far worse. The October 1896 edition of the A.P.A. Magazine (American Protective Association) features an address by H.W. Bowman in which he contrasts Roman Catholic and black slavery. Though acknowledging "the awful curse of African slavery," Bowman downplays it in comparison to Roman slavery, which is "a system of slavery that has been a greater curse to the world than African slavery ever was" ("Romanism Defined" 1455). "The lash of the slave driver," Bowman adds, "had not half the terror for the African slave that the whip of purgatory has for the papal slave," in effect downplaying the cruelty of the nation's past. ${ }^{41}$ Of course, in a whitedominant society, where separate was not equal, any attempt, real or imagined, to enslave a white man had more social and political weight than the very real, ongoing disenfranchisement of African Americans. This dynamic, in which imagined plots receive greater attention than do actual problems, is one of the more unfortunate aspects of conspiracy thinking. Energy that could have been devoted to fighting Jim Crow laws was instead directed fighting for convents to be opened to public inspection, for " $[t]$ he 
southern taskmaster with his whip was never more heartless than some of the mother superiors."

In addition to giving Gilded Age whites yet another means by which to forget black slavery, Chiniquy's narrative had the appeal of mitigating culpability for the war by taking blame away from (white) Americans and shouldering it upon Roman Catholics. In effect, the conspiracy theory of Catholic causation for the Civil War allowed for reconciliation among Protestant Americans by blaming a foreign foe. Indeed, some anti-Catholics saw in their message and their organizations the ability to rally the blue and gray together as one. "There is no longer a Mason and Dixon line in this country," states an 1896 edition of the anti-Catholic and nativist A.P.A. Magazine (1896), “The A.P.A. has wiped it out. The North and the South will soon be united in one grand organization, standing for America and against the world" (886). ${ }^{42}$ In an 1895 address to the Supreme Council of the American Protective Association, A.P.A. president William J. H. Traynor paints a vision of sectional reconciliation through union against Catholicism. Though thirty years distant from the Civil War, Traynor describes the nation as still "divided against itself," thus allowing the "enemies of the Republic to reap a golden and political harvest" (164). But with the spread of the A.P.A. into the South, Traynor sees the end of sectionalism and the dawn of a new union between North and South. He optimistically predicts that " $[\mathrm{t}]$ he next session of this organization will witness such a representative reunion of North and South as has not been seen in forty years." Continuing with his reconciliationist language, Traynor speaks of that future meeting being one in which "the gospel of brotherly love will be preached, and hands that were once cold with enmity ... will once again clasp each other in the 
pledge of a common cause and purpose — one flag, one nation, one people.” A mutual foe, especially a foreign one, could be the means of reconciling brothers. ${ }^{43}$ With Chiniquy's own contribution of a Lincoln-centered conspiracy theory, Fifty Years, too, appropriates the cause of unity among postbellum Americans via enmity for Roman Catholics.

During both Chiniquy's alleged first and third visits to the Lincoln White House, Fifty Years has the commander-in-chief charge the Catholic Church as the true (and secret) agent behind the nation's war. According to Chiniquy, by August 1861 Lincoln had an increasing awareness that the war between the states originated in the papal states: "I feel more and more, every day, that it is not against the Americans of the South, alone, I am fighting, it is more against the Pope of Rome, his perfidious Jesuits, and their blind and blood-thirsty slaves, than against the real American Protestants" (696). The text here constructs an opposition between South and North but it also does so between "Americans," who could be "of the South," and those enslaved to Roman priests (and not southern masters). The Mason-Dixon line does not determine who's a "real American" but rather where one falls on the Catholic/Protestant continuum does, a point perhaps alluded to in the descriptor, "real American Protestants." For nineteenthcentury anti-Catholics and nativists, to be a "real" American, true to the Republic and the constitution, one had to be a faithful Protestant (Chiniquy's phrase also possibly indicting Protestants who are not "real" Protestants, such as those lulled to sleep concerning the Catholic threat). Defining "American" as Protestant, without reference to one's sectional loyalties, fits well with the post-reconstruction desire to unite those formerly at odds with one another. According to Chiniquy, at one point (June 1864), 
Lincoln explicitly states that if Protestant Americans from both sections of the country knew the true instigators of their conflict, they would end their civil war and band together in a holy war: "The Protestants of both the North and the South would surely unite to exterminate the priests and the Jesuits, if they could hear ... of the plots made in the very city of Rome to destroy this Republic" (699).

Not everyone sees the war in the same light as Chiniquy's Lincoln. He acknowledges, "This civil war seems to be nothing but a political affair to those who do not see, as I do, the secret springs of that terrible drama." As I discussed in chapters one and two, this is a typical move in conspiracy rhetoric: it takes an expert to see the plot. ${ }^{44}$ Lincoln has been enlightened. But while he sees how that the "true motive power" behind the nation's problems lies "secreted behind the thick walls of the Vatican" (714), Lincoln chooses not to reveal what he knows. ${ }^{45}$ This one-man government cover-up arises out of fear-fear of an even more deadly war. What would happen if the people knew the truth about the Catholic nature of the war, and the Church's desire to end liberty in the nation - to, in effect, make white men slaves, too, though of a Roman and not a southern master? "[I]f the people knew the whole truth," Lincoln tells Chiniquy, "this war would turn into a religious war, and it would, at once, take tenfold more savage and bloody character." While Lincoln conceals the truth, there is one with whom he talks openly: "You," he tells Chiniquy, "are almost the only one with whom I speak freely on that subject" (715). Here Fifty Years heads off a potential challenge to its appropriation of Lincoln. Why is there no record, outside of Chiniquy's narrative, of an anti-Catholic Lincoln? For that matter, the public pronouncements of the president on the war's causes are hard to square with Chiniquy's Catholic conspiracy theory. To cite 
one example, less than a year after Chiniquy's third and last alleged visit, during his second inaugural, Lincoln describes African American, not Catholic, slavery as "the cause of the war" (Speeches and Writings, 1859-1865, 686). But by taking the president's remarks off the record until nearly twenty years after his death, Fifty Years is able to use as a witness one whose alleged testimony cannot be directly questioned. In the court of rhetoric, appropriating the ethos of the dead, who cannot disclaim or deny their usage, has its own advantage.

The Lincoln of historical record is not anti-Catholic. He never, for instance, joined the most prominent anti-Catholic political movement of his age, the KnowNothings (the antebellum equivalent of the Gilded Age American Protective Association) - a movement whose American Party saw significant, albeit temporary, national electoral success in the mid-1850s. "I am not a Know-Nothing," he wrote his close friend, Joshua Speed, in August 1855, a few months before he met Chiniquy (24 Aug. 1855, Speeches and Writings, 363). Lincoln grounded his opposition upon the same principle and document with which he would blast African American slavery: the equality promised in the Declaration of Independence. "As a nation," he tells Speed, "we began by declaring that 'all men are created equal.' We now practically read it 'all men are created equal, except negroes.' When the Know-Nothings get control, it will read 'all men are created equal, except negroes, and foreigners, and catholics."' If this comes to pass, Lincoln would leave the so-called land of the free for Czarist Russia, for "I should prefer emigration to some country where they make no pretence of loving liberty--to Russia, for instance, where despotism can be taken pure, and without the base alloy of hypocrisy." Although Chiniquy's Lincoln does not align with the 
historical record, the impact of myth can be as potent as that of history. ${ }^{46}$ It is the power of both his history and legend that made — and makes — Lincoln's ethos so desirable for social and political movements to appropriate. And many, including the anti-Catholic movement, have done so. As Robert Todd Lincoln, when asked in 1922 by a Catholic magazine about alleged anti-Catholic feelings in his father, responded, "I do not know of any literature in which my father is quoted as attacking Catholics and the Catholic Church. Of course, in the years his name has been a peg on which to hang many things" (qtd. in George 20).

The continued use of the ethos of appropriation in conspiracy rhetoric can be seen in contemporary usage of both President Lincoln and President Kennedy. An email newsletter (someoftheabovenews, Myra M. Jackson, editor) posted on a 9/11 revisionist website (911blogger.com), appropriates Lincoln's ethos to provide legitimacy to its claims. ${ }^{47}$ Quoting Walter Karp's 1974 Indispensible Enemies: The Politics of Misrule in America (117), the newsletter offers its readers "Abe Lincoln on 'Conspiracy Theories"" (note the use of the folksy "Abe" in the article's title). In antebellum days, there were conspiracy fears in both the South and the North concerning both the proand anti-slavery movements, and Lincoln himself did use conspiracy rhetoric against slavery. The newsletter, however, appropriates Lincoln (as interpreted by Karp) to provide a level of psychological comfort to those who will be labeled conspiracy theorists for their 9/11 revisionism: "If, after reading this speech, anyone is still ready to denounce as paranoid the political analysis of political deeds, he will have to admit that Abraham Lincoln was suffering from 'conspiratorial fetishism." The ethos of Lincoln 
is thus appropriated for the truther movement: if they call you conspiracy theorists, you're in good company, for they would have to call Lincoln the same thing.

The ethos of President Kennedy is also appropriated by contemporary conspiracy theorists, in particular, his April 27, 1961 speech, "The President and the Press. ${ }^{״ 8}$ Delivered to the American Newspaper Publishers Association, the speech discusses the relationship between freedom of the press and national security during the Cold War (it was given less than two weeks after the disastrous Bay of Pigs Invasion (April 17-19, 1961). Kennedy argues for two objectives "that may seem almost contradictory in tone": "first, ... the need for ... far greater public information; and, second, ... the need for far greater official secrecy." It is Kennedy's words about secrecy that have found a home among current conspiracy theorists: "we are opposed around the world by a monolithic and ruthless conspiracy that relies primarily on covert means for expanding its sphere of influence. ${ }^{.49}$ Although the context is clearly the Cold War between the West and the Soviet Union, conspiracy theorists see in Kennedy's speech an acknowledgement of other global conspiracies against the United States than international communism. Believers differ on exactly whom Kennedy is describing. One YouTube video, for instance, plays Kennedy's speech with a variety of images of different groups coming up on screen: the Jesuits, the Illuminati, the Bilderberg group, and the Masons, as well as multiple images related to 9/11 (archosz, "JFK about 9/11 and the emergence of a New World Order")..$^{50}$ But rather than hearing a condemnation of communism, believers hear a warning about the secret rulers of their choice. And for some modern anti-Catholics, Kennedy's "monolithic and ruthless conspiracy" is the Catholic Church. Greg Szymanski, for instance, describes Kennedy's real intent behind 
the speech as one "to expose Jesuit and Vatican control” (“JFK's Hidden Agenda Speech Should Be Remembered"). ${ }^{51}$ Indeed, according to Szymanski, Kennedy’s speech at New York's Waldorf-Astoria Hotel would eventually lead to a Jesuit bullet in Dealey Plaza: "his words . . . assuredly signed his death warrant for the Vatican." Granted, Szymanski is assassinating the character of the Catholic Church by making it responsible for the murder of a beloved president. But he is also appropriating Kennedy for his message. To make his anti-Catholic point, he takes Kennedy's words, Kennedy's murder, and Kennedy's ethos: if you believe in Kennedy, then believe what he said about the Catholic conspiracy. ${ }^{52}$

Questions about truth, knowledge, and authority are the heart of conspiracy theory. There is a putative quest for knowledge and truth — but it is a knowledge that can be difficult to find, and a truth that can be challenging to prove. As such, conspiracy theories raise questions about authority — who can be believed? Who can be trusted? Melley writes, "conspiracy theory arises out of radical doubt about how knowledge is produced and about the authority of those who produce it" (13). To these doubts, the ethos of appropriation provides an answer, by placing a disputed or disputable claim (the conspiracy theory) within the mouth of someone who is trusted. By appropriating the ethos of someone viewed as trustworthy, a message itself gains trust from an audience. This is the power of the ethos of appropriation.

\section{The Catholic Church, Enemy of Lincoln: The Ethos of Assassination}


Speakers with bad messages can establish good ethos with their targeted audience. Although his message was reprehensible, given his ability to construct a character that helped him lead Germany into world war, Adolf Hitler, unfortunately, was an effective orator. But the negative uses of ethos construction are not limited to the hateful narratives and propagandas of a moral monster. Rhetors of all stripes often construct a positive ethos for themselves and a negative ethos for their opponents, associating the reprehensible with and appropriating the disreputable for a message they find objectionable. For examples, see the proclivity on the internet (and elsewhere) for comparisons to Nazis such as "describing women's rights campaigners as 'feminazis', comparing the former US President George W Bush to Hitler, or saying Barack Obama's proposed healthcare reforms are the new Holocaust" (Chivers) ${ }^{53}$

In this section, I examine ethos in a negative light — when it is created to diminish an opponent, when it is a case of character assassination. Chiniquy uses his conspiracy theory of a Catholic hand behind Booth's pistol to portray the Catholic Church as having the nefarious character of an assassin — the text constructs an ethos for the Church as a murderer. In examining the assassination theory of Chiniquy, I consider assassination as a trope in conspiracy rhetoric. Anti-Catholics cited a pattern of alleged Catholic murders, including presidential and royal assassinations, but, as can be seen in the conspiracy narratives surrounding a variety of famous (or infamous) deaths, from J.F.K. to Princes Di, the assassination trope has not been limited to anti-Catholic rhetoric. In conspiracy theory, literal assassination serves as a powerful trope for the rhetorical assassination of the character of one's opponents. 
Assassinating a Nation's President

From the beginning of the alleged Chiniquy/Lincoln friendship, Fifty Years focuses on the Catholic Church as a deadly opponent of Lincoln. Starting with Lincoln's 1856 legal defense of Chiniquy, Fifty Years portrays the Church as out to murder Lincoln having been bested by him in court (663-64). For some unstated reason, the Church does not kill Lincoln soon after the trial; but according to Chiniquy, once Lincoln becomes president, there is no shortage of attempts. An anonymous ex-priest's report that "there was a plot among them to assassinate the president" (691) leads to Chiniquy's first White House visit (late August 1861). But before Chiniquy can detail this plot, he is greeted by Lincoln's own allegation of Catholic involvement behind the Baltimore Plot. ${ }^{54}$ Lincoln describes the murderous cabal as being "almost entirely composed of Roman Catholics," with "two disguised priests . . . to lead and encourage them" (692). But what the Catholics fail to accomplish in Baltimore, they will attempt to do via the Democratic Party-influenced press. Lincoln asks Chiniquy why "a great number of Democratic papers ... [have] publish[ed] that I was born a Roman Catholic, and baptized by a priest" (693-94), leading them to call him "an apostate" (694). ${ }^{55}$ Lincoln rejoices: "Thanks be to God, I have never been a Roman Catholic.” Chiniquy then explains that it was because of this story that he had come, for he had heard "from the lips of a converted priest," whom Chiniquy never names, that the story was published "in order to incite the fanaticism of the Roman Catholic murderers, whom they hope to find ... to strike you down.” By making Lincoln an apostate, Chiniquy argues, the Church has made it open season on the president for "in the Church of Rome, an apostate ... has no right to live.” These are no rogue Catholics. 
In their final meeting (June 1864), Lincoln and Chiniquy discuss one further attempt to kill Lincoln — the alleged recognition of the Confederacy by the papacy. In response to a letter from Jefferson Davis, and the visit of a Confederate envoy (A. Dudley Mann), Pope Pius IX had written Davis (late 1863), addressing him as the "Illustrious and Honorable Jefferson Davis, President of the Confederate States of America" (qtd. in Alvarez 242). This language was thought by some to be a papal recognition of the legitimacy of the Confederate union and used to such effect by Confederate sympathizers in Europe (see Alvarez 242-43). But according to Alvarez (1983), "the Vatican considered it merely a polite acknowledgement of Davis' letter" (243). When Rufus King, the Union's minister to the Vatican, met with Cardinal Antonelli (the Vatican's secretary of state), he was assured that the letter had no political import and that similar language would have been used in a letter addressed to President Lincoln. However, the polite language of the pope, in the hands of Chiniquy becomes an arrow against the president: "That letter is a poisoned arrow thrown by the Pope, at you personally; and it will more than a miracle if it be not your irrevocable warrant of death" (700). Rather than being proof of diplomatic, epistolary conventions, the letter evidences a clear plot by which to make Lincoln not only an apostate but also a tyrant. Lincoln agrees with Chiniquy's assessment: "You confirm in me the views I had taken of the letter" (702). Thus, Lincoln himself confirms the truthfulness of the Chiniquy conspiracy plot.

The final and fatal attack is by John Wilkes Booth, who Chiniquy labors to prove was, in effect, a puppet for Rome: "Booth was nothing but the tool of the Jesuits. 
Rome was directing his arm. ..." (718). ${ }^{56}$ Like contemporary J.F.K. conspiracy theorists, Chiniquy claims to investigate thoroughly the president's assassination, writing of having spent "twenty years of constant and most difficult researches." Indeed, his inquiry begins "not long after the execution of the murderers," with a trip "incognito" to the nation's capital (725). There he finds government officials unwilling to talk with him, unless he agrees to not name them. And when some of them do speak, off the record, they admit, "We had not the least doubt that the Jesuits were at the bottom of that great iniquity." However, the government men (unlike Chiniquy) do not pursue the Jesuits, justifying their choice as having been done for the public's good: the sight of guilty and condemned priests hanging from Union gallows, would have given "a new life" to the forces of "discord." Riots would have followed, and the country needed peace and not more bloodshed. Although Chiniquy believes the government's "great" and "fatal mistake" was "to constantly keep out of sight the religious element of that terrible drama" (724), the anonymous officials appropriate the spirit of Lincoln to justify their inaction. "For you know it well," they tell him, "there was nothing which that great and good man feared so much as to arm the Protestants against the Catholics and the Catholics against the Protestants" (725).

\section{Assassinating an Opponent's Ethos}

A positive ethos construction helps gain an audience's trust by demonstrating a trustworthy character. In a similar vein, constructing a negative ethos for one's opponent also helps gain an audience's trust by revealing that, in contrast, the opponent is so profoundly unworthy of trust: by constructing a villain, I make myself a hero. If 
one wishes to take on the role of being a victim of persecution, then the evil of the persecutor must be emphasized. This is ethos through comparison and contrast - the worse they are, the better I am. In the case of assassination, an audience is being asked, "How can you trust someone who would stoop to do something so cowardly?" Rhetorically, there is much to be gained by connecting one's opposition to allegations of assassination, especially the murder of a beloved figure such as Lincoln.

As with any historical event, assassinations are open to contending, conflicting interpretations ${ }^{57}$. Even when done before an audience, as with Lincoln's shooting at Ford Theater, the attempt to understand political murder brings multiple challenges. For assassinations are not merely about the facts of the case, they are also about their analysis: what some consider a justifiable tyrannicide, others might see as an act of terrorism. Narratives compete for the public's attention, as can be seen in the multiple conspiracy theories surrounding the death of President Kennedy, with the Cuban government, the Soviet government, the American mob, the C.I.A., and even President Lyndon Johnson all being cast as the real force behind 11/22/63. (The satirical website The Onion captures the abundance of alleged suspects with their November 22, 1963 faux newspaper headline: "Kennedy Slain By CIA, Mafia, Castro, LBJ, Teamsters, Freemasons. President Shot 129 Times from 43 Different Angles" ["November 22, 1963"]. $)^{58}$ In the case of Lincoln, the first suspect was not the Catholic Church—it was the Confederate States of America, with the Union government offering a $\$ 100,000$ reward for the capture of Jefferson Davis, alleging he (among others confederates) had "incited, concerted, and procured" the death of Lincoln (qtd. in Hanchett 64). In the days following, Davis would not be the only one accused: conspiracy fears would arise 
concerning Lincoln's successor, Andrew Johnson, and his secretary of war, Edwin M. Stanton.

The assassination of Lincoln was a "political act" (Hanchett 6). As such, it has been open to rhetorical and partisan use. In a presidential election year speech (September 21, 1876) to Union veterans, the famed Republican orator Robert G. Ingersoll indicted the Democrats for the evils of the Civil War, including Lincoln's death: "The man that assassinated Abraham Lincoln was a Democrat. Every man that sympathized with the assassin — every man glad that the noblest man ever elected was assassinated, was a Democrat" (158). ${ }^{59}$ Other assassinations and assassination attempts have also been used to paint opponents in a cowardly and dastardly color. In 1835, Richard Lawrence tried to shoot President Andrew Jackson. He failed, was tried, and sent to an asylum where he died. But contemporary supporters and opponents of Jackson used the attempt to depict their foes. Several years later, John Smith Dye would use the Lawrence shooting as evidence of a slave power at work against the country (see Jesse Walker's 2013 The United States of Paranoia: A Conspiracy Theory, 3-8). Allegations of assassination can be politically useful in that they portray the opposition in an undesirable light, for assassination carries with it multiple negative connotations. As the Oxford English Dictionary (online) states, it is an act of treachery: "the taking of the life of anyone by treacherous violence." In addition to its duplicitous nature, its practitioners have often been portrayed as mentally deranged. James W. Clarke (2007) describes the psychological literature through "at least the early 1980s" labeling American assassins as 'all 'paranoid schizophrenics,' describing them as short, loner, white males acting in the grip of delusions of persecution and grandeur" (3). Historical 
work also described them as "mentally disordered subjects driven by irrational or irresistible impulses. ${ }^{, 60}$ Additionally, assassination strikes at the core of an elective government. Booth negated the vote of $55 \%$ of the electorate, over 2,000,000 people, who had cast their ballot for Lincoln in the 1864 election. The assassination of an American president at least temporarily handicaps one of three branches of the federal government. ${ }^{61}$ And while a vice president may be quickly sworn in to replace the murdered president, the effect on the public can be significant, for "political figures can be regarded as symbolic representations of their nations" making their murder an attack not only upon "the individual but [also] the entire collectivity" (Alexander et al., [2011] ix). Indeed, political assassination "can call into question the democratic and civil identity of a nation and initiate a long soul-searching, which may not only destabilize morale, but undermine the capacity for optimism and reform." In the case of Lincoln, Booth's bullet elevated Andrew Johnson to the Executive Office at a key point in the nation's history. The war that divided and almost destroyed the union is over, and the start of reconstruction has begun. The civil rights of millions of recently freed slaves are in the balance. Unfortunately, the man Booth singlehandedly placed in the White House was one whom Elizabeth D. Leonard (2004) describes as resisting "any sort of plan to ensure the social and political uplift of the freedpeople" (xii). As Gerald J. Prokopowicz (2011) states, “Andrew Johnson was no Abraham Lincoln" (166). ${ }^{62}$

Historically, there have been attempts to justify assassination in the case of eliminating a tyrant: "The [ancient] Greeks," for instance, "appeared to condone tyrannicide" (Crotty [1971] 5). But even when theoretically warranted, the act of assassination "in the abstract ... was not well received and was argued only as a 
measure of last resort" (Crotty [1971] 6). ${ }^{63}$ "The laws of war in Abraham Lincoln's century," in fact, writes Mark E. Neely, Jr., "forbade assassination" (913). The relevant section of the War Department's guiding code (Section 9, article 148) did "not allow proclaiming an individual belonging to the hostile army, or a citizen, or a subject of the hostile government an outlaw, who may be slain without trial by any captor," explaining, "Civilized nations look with horror upon offers of reward for the assassination of enemies as relapses into barbarism" (qtd. in Neely 913). In a letter (July 15,1864 ) to the American consul in Paris, Secretary of State William Seward (who himself would be the object of assassination on April 14, 1865) explained why there were "no grounds for anxiety" concerning threats against Lincoln: "Assassination is not an American practice or habit, and one so vicious and so desperate cannot be engrafted into our political system" (qtd. in Kaufman 135). But within a few months from Seward's letter, assassination would profoundly affect the American system. Though Booth might have seen himself as a patriot, the grieving nation saw his act as one of cowardice - a charge seen throughout the United States' lengthy compilation of condolence expressions following the Lincoln's death, The Assassination of Abraham Lincoln, Late President of the United States of America: And the Attempted Assassination of William H. Seward, Secretary of State, and Frederick W. Seward, Assistant Secretary, on the Evening of the 14th of April, 1865: Expressions of Condolence and Sympathy Inspired by These Events (1867). ${ }^{64}$ The London Morning Star (April 27, 1865) spoke of "the coward hand of a vile assassin" (qtd. in Assassination 510). One group decried the act as having been done in a "manner unsurpassed for cowardice and treachery," while a large number spoke of it as cowardly 
act. It was a "cowardly crime," "cowardly atrocity," “cowardly and detestable," committed by "cowardly wretches" and a "cowardly assassin" (qtd. in Assassination 45, 214, 230, 329, 480, 643). ${ }^{65}$ Chiniquy's Lincoln touches upon this theme when he describes Protestant "nations who read their Bible" as ones who "fight bravely on the battlefield, but ... do not assassinate their enemies" (696). It is the "Pope and the Jesuits" who are "the only organized power in the world which have recourse to the dagger of the assassin." Assassination was barbaric, desperate, vicious, un-American, un-Christian, and a profound act of cowardice. As such, it was the perfect crime to attach to and thus attack the ethos of one's opponents.

Anti-Catholic speakers and writers would use the assassination trope with more than just Lincoln. The Southern Guardian (January 10, 1914), the official newspaper for the Catholic diocese of Little Rock, Arkansas, described some as "unkind enough to charge all crimes to Catholics," with allegations that "the three assassins who took the lives of our murdered presidents were Catholics" ("Three Assassins and Their History" 5). ${ }^{66}$ The article then shares a refutation from the Milwaukee Catholic Citizen, which begins with Chiniquy's Lincoln "legend," describing it as having "marched along" despite a paucity of evidence. Rather than wasting away, it has gained "additions ... for if people will believe that Booth was a Catholic," why not believe that "all the assassins of American presidents were Catholic?" Indeed, “anti-Catholic lecturers [are] asserting that Charles J. Guiteau [who shot President Garfield] was a Catholic, and likewise the anarchist who shot McKinley." The multiple claims of assassination point to its (negative) rhetorical potential. For if a church will assassinate a president—on Good Friday — what will it not stoop to do? This taps into a fear that comes with assassination: 
no one is safe. If conspirators can kill the president, then they can kill anyone. Earlier in Fifty Years, Chiniquy recounts a conversation with a former schoolmate, Desaulnier, which broadens the threat of Catholic assassination from president to all Protestants. Desaulnier, who would become a teacher of philosophy (147), regrets ever having read the Church's theologians, for they are "without heart, soul or logic," and "Every one of them," he adds, "would like to make an assassin of every Catholic." In fact, "Were we acting according to the principles of those theologians, we would slaughter all Protestants." Thus, the assassination threat in Fifty Years is not just Booth against Lincoln; it is also Catholic against Protestant. For the assassin is not just a man- the assassin is the Church. ${ }^{67}$

Peter Knight describes the Kennedy murder as having “inspired more conspiracy thinking in America than any other event in the twentieth century" (76). As this continued fascination demonstrates, assassination remains a popular trope in conspiracy rhetoric. Although the Kennedy death may grab the majority of attention, it is far from alone. Almost any death of the powerful or prominent can be traced to some conspiracy’s assassin. Thus, Marilyn Monroe's drug overdose, Princess Diana's car crash, and John Lennon's shooting have all been charged as the result of secret assassination plots. For Ventura, "elements of the CIA and FBI" were behind the death of Malcom X (44); James Earl Ray was “another 'patsy,' like Oswald (53); and Sirhan Sirhan “was hypnotically 'programmed,' using methods developed by the CIA, to take part in the murder" (65). In conspiracy literature, assassins are everywhere, and if they are not gunning for you, they are gunning for your country: the very nature of 
assassinations is represented as anti-democratic and anti-American. Assassinations lend themselves to conspiracy theorization, in part, because they can be the result of genuine conspiracies — neither Booth nor Brutus acted alone. When perceived as part of a greater conspiracy, assassination raises a variety of fears, both collective and individual. But even when a greater plot with a more extensive or elusive cast of characters does not exist, the charge of assassination, with its connotative power to drag down the perceived character of one's opponents, carries with it persuasive muscle. It creates a binary in which the opponent is placed against democracy, the rule of law, and the nation itself. For assassination is, after all, a fatal suspension of habeas corpus. In the case of Booth or Oswald one man becomes judge, jury, and executioner. Assassination calls into question the contract between state and citizen of protection, both physical and legal, for those who abide by the law. Greg Woolf (2007) describes the perception (right or wrong) held by members of so-called liberal democracies toward assassination. ${ }^{68}[\mathrm{~W}]$ hen it occurs," he writes, "it feels like an assault on the moral foundation of the state" because the state itself is supposed to be the arbiter of "legitimate violence," where only the military and the police allowed "under tightly defined rules of engagement ... to kill” (53). Indeed, the presence of political violence "is one of the most common signs taken to show that a state does not live up to the ideals of liberal democracy" (54) ${ }^{69}$ Whether one accepts this understanding, assassination is a profoundly anti-democratic act. And constructing a foe as an assassin is to paint one's opponent as barbaric, vicious, desperate, cowardly, anti-American, and anti-democracy, which serves to create a negative ethos for the adversary. This is the rhetorical power of the ethos of assassination. 
Having in my second and third chapters analyzed how Fifty Years constructs Chiniquy's ethos, in my next chapter, I expand the focus of my dissertation beyond the text of Fifty Years, examining how the public use of Chiniquy's conspiracy rhetoric from the nineteenth through the twenty-first centuries. Using three different genres (magazine, comic book, and websites) from three different periods (the Gilded Age, 1980, and contemporary), I will examine its continued use by anti-Catholics and nativists. Chapter Four explores the reception by anti-Catholics of Chiniquy's conspiracy theory, focusing in particular on how his—and Lincoln's — ethos were used to make credible the anti-Catholic message. Whether it ever converted a Catholic, Chiniquy's claims, cloaked in conspiracy, embodied in his own self and ethos, were published believed in his lifetime and beyond, and they continue to have a place in today's World Wide Web. As such, they help us understand the public nature of ethos used to make conspiracy claims.

\footnotetext{
${ }^{1}$ In his review for The Journal of American History (Dec. 1994), David W. Blight describes Peterson's book a "remarkable chronicle of what Alfred Kazin called 'that greatest of all American works of art, the people's memory of Lincoln"” (1265).

${ }^{2}$ Coretta Pittman (2007) describes how "black women writers have remade a negative ethos into a positive one" (45).

${ }^{3}$ Though he is not explicitly discussing ethos, Quintilian borrows Cato's definition and famously describes his ideal orator as "a good man skilled in speaking" (12.1.1). Indeed, Quintilian argues that "no man, unless he be good, can ever be an orator" (12.1.3). For Quintilian, the aim of rhetoric was a noble one that required requisite virtues making it impossible for a bad man to promote for this good cause. His argument, in part, is a definitional one. Besides his own twelfth chapter, for more on Quintilian's good man theory, see Miriam Brody's (1993) Manly Writing: Gender, Rhetoric, and the Rise of Composition (11-36).

${ }^{4}$ Pittman describes the problems faced by black female writers facing ethos as constructed in the Aristotelian tradition: "If Aristotle's conception of persuasive discourse and ethos is the standard by which we have historically measured human character, and I believe it is, then we need to rethink how ours and others' evaluations have been unfair to black women" (68).
} 
${ }^{5}$ For historical background on Burke's essay, see Garth Pauley's (2009) "Criticism in Context: Kenneth Burke's 'The Rhetoric of Hitler's "Battle."' Pauley describes Burke's essay as being "heralded as one of Kenneth Burke's greatest essays and as an exemplar of rhetorical criticism." http://kbjournal.org/content/criticism-context-kenneth-burkesrhetoric-hitlers-battle.

${ }^{6}$ Burke's own discomfort for recognizing Hitler's rhetorical skill can be seen when he describes his response to Hitler's chapter "Strong Man Is Mightiest Alone": "I had thought . . . that I was going to find Hitler at his weakest. Instead, I found him at his strongest. (I am not referring to quality, but to demagogic effectiveness.)" (210). ${ }^{7}$ Steven B. Katz (1992) argues for an "ethic" and "ethos" of expediency in Nazi Germany that were "at least partially responsible for the holocaust" (258). Although Katz's essay focuses on group, organizational, or national ethos, he does write of Hitler's own ethos: "if the purpose of Hitler's propaganda was to instill in the German people an ethos of detachment and power by which the Aryan race would build the Third Reich, as leader of the race Hitler sought to embody this ethos himself. . . . If ethical appeal, the most important of the three appeals for Aristotle . . , is created when the speaker convinces the audience that he or she possesses sound sense, high moral character, and good will . . ., Hitler redefines these ethical categories based on the ethic of expediency, reducing them to their basest, 'technical' level"' (268).

${ }^{8}$ In their 2013 textbook, Understanding Rhetoric: A Graphic Guide to Writing, Losh et al. define ethos as "the credibility that a speaker or writer brings to the subject" (44). However, prior to providing that definition, they suggest "English counterparts" for Aristotle's Greek words, with ethos having "ethical" and "ethics" as its counterparts (43).

9 "Defining ethical appeal as I have as I have proposed puts ethics back into 'ethical appeal' by reserving the term only for those rhetorical appeals the ethics of which are perceivable to an alert observer. . . Ethical appeal as I have defined it is to a large degree disassociated from ethos as traditionally defined" (54).

10 Judy Holiday (2009) writes, "many contemporary rhetorical scholars have turned to ethos as meaningful framework for talking about ethics" (389).

${ }^{11}$ Ethos is, of course, always contextual, and I am not suggesting that ethos has never been understood "negatively." Rather, I am suggesting that its use for negative purposes is not often foregrounded.

${ }^{12}$ In describing ethos as associative, I am not arguing for the psychological understanding of the mind and memory that held sway for a number of years known as associationism. C. George Boeree (2000)describes this theory as the view "that the mind is composed of elements -- usually referred to as sensations and ideas -- which are organized by means of various associations. Although the original idea can be found in Plato, it is Aristotle who gets the credit for elaborating on it." Aristotle gave four laws of association: contiguity, frequency, similarity, and contrast (Boeree). As a dominant way of understanding the mind and memory, associationism affected how rhetoric was understood. According to Sharon Crowley, for instance, nineteenth-century rhetorician George Campbell's "theory of rhetorical invention was indebted to two psychological traditions: faculty psychology and associationism" (The Methodical Memory 16). For more on associationism, including John Locke's views, see Howard Wilson's A History 
of the Association Psychology (1921), available here:

https://archive.org/details/historyoftheasso007979mbp

${ }^{13} \mathrm{http}$ //www.npr.org/2012/09/06/160713941/transcript-president-obamas-conventionspeech

${ }^{14} \mathrm{http} / / /$ content.time.com/time/specials/packages/completelist/0,29569, 1844704,00.html

${ }^{15}$ Lincoln "handled at least sixty-eight slander lawsuits during the course of his career, representing plaintiffs thirty-four times and defendants thirty-four times" (Steiner 5).

${ }^{16} \mathrm{https}$ ://archive.org/stream/lifeoncircuitwi00whitgoog\#page/n10/mode/2up

17 According to the agreement of dismissal, "the defendant [Chiniquy] denies that he has charged, or believed the plaintiff guilty of Perjury; that whatever he has said from which such a charge could be inferred, he said on the information of others, protesting his own disbelief in the charge; and that he now disclaims any belief in the truth of such charge against said plaintiff [Spink]" (qtd. in Steiner 16).

${ }^{18}$ Chiniquy calls Spink a "heartless land speculator" (635).

19 According to Michael Burlingame (2008), Lincoln was known to charge "notoriously low fees" (332), and this practice would be used during his 1860 campaign as proof of the quality of his character (333). In light of other fees Lincoln charged, Chiniquy's \$50 fee is not necessarily all that low. For instance, Burlingame cites another slander case in which Lincoln requested a \$25 fee: “'We were astonished,' recalled opposing counsel, 'and had he said one hundred dollars it would have been what we expected. The judgment [\$600] was a large one for those days; he had attended the case at two terms of court [just as he had with Chiniquy], had been engaged for two days in a hotlycontested suit, and his client's adversary was going to pay the bill'" (332).

${ }^{20} \mathrm{https}$ ://archive.org/stream/greeleyonlincoln00ingree\#page/n $7 /$ mode/2up

${ }^{21}$ See also Fehrenbacher and Fehrenbacher's description of the challenges of memory in connection with the remembered words of Lincoln (xlv-liv).

${ }^{22} \mathrm{http}$ ://babel.hathitrust.org/cgi/pt?id=inu.32000001999103; view=1up;seq=9

23 "[S] ome persons stretched limited acquaintance into intimate friendship; some exaggerated the amount of time spent in Lincoln's company; some overstated their influence upon him; and more than a few supplemented memory with outright invention, especially in the reproduction of dialogue. Egocentric bias, a common feature of reminiscence, is especially prominent in certain recollections of Lincoln that are plainly self-serving in their accounts of conversations with him" (Fehrenbacher \& Fehrenbacher xlix).

${ }^{24}$ My thanks to Allan Pequegnat of the Chiniquy Collection for these letters and other materials: http://www.chiniquy.ca/

${ }^{25}$ James Cornelius, Curator of the Lincoln Collection in the Abraham Lincoln Presidential Library and Museum (Springfield, Illinois), suggested that Robert Lincoln's handwritten note be understood as "but plainly [plausibly?] none more warm than yourself" (personal correspondence, August 6, 2013). Emerson, whom Cornelius describes as the best person at reading Robert Lincoln's handwriting, concurs: "Yes, it is 'plainly, none more warm than yourself'" (personal correspondence, August 12, 2013).

26 "Thanks for your email. I cannot recall coming across anything during my research on RTL and the Catholic Church. By 1909, Robert was receiving more than 100 letters 
a day about every conceivable aspect of his father, such as his temperance or intemperance, his belief or non-belief in Spiritualism, his devout Christianity or his atheism, etc, etc. I can tell you that the letter you quoted in your email is typical of RTL's responses to all letter writers -- he would thank them and make them believe they were correct in their assumptions without really himself taking a stand either way.

Robert was a quintessential Victorian gentleman, and he rarely ever openly disagreed or challenged people in their personal beliefs on his father. He always said it was for others than himself to decide. Only in the most offensive, egregious or slanderouslyridiculous claims did Robert ever challenge people's assumptions or interpretations.

So in my opinion this letter you cite does not prove anything about a Catholic Conspiracy (CITE)."

27 "The fact that Robert says his father made many friends but "plainly" none more so than yourself convinces me that Robert was simply being polite, agreeing to Chiniquy's belief in his closeness to Abraham Lincoln" (Jason Emerson, personal correspondence, August 11, 2013).

${ }^{28}$ They do not just quote evidence or the evidence or experts; rather, they associate themselves with experts.

${ }^{29}$ See Crowley's description of Griffin, in which she acknowledges that "it is not easy to write him off as a wing-nut alarmist wearing a tin-foil hat," pointing to his professorship at Claremont Graduate University, where he "taught theology and ethics for nearly thirty years," with a scholarly publication record that is "impressive" (177). Griffin has written The New Pearl Harbor: Disturbing Questions about the Bush Administration and 9/11 (2004).

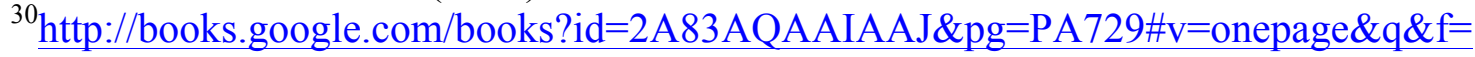
false

${ }^{31}$ See Peterson for examples of the political use of Lincoln, including that by Republicans to advance a protective tariff and that by Democrats opposed to American involvement in the Philippines (155-160).

${ }^{32}$ See Paul F. Boller, Jr., and John George's (1989) They Never Said It: A Book of False, Quotes, Misquotes, and Misleading Attributions (77-94); Ralph Keyes's (1992) "Nice Guys Finish Seventh": False Phrases, Spurious Sayings, and Familiar Misquotations (95-98).

${ }^{33}$ On the social nature of ethos, see Reynolds.

${ }^{34}$ Lewis describes Chiniquy has having an "unbalanced imagination" that "led him to expand some simple remarks of the President into a metaphysical monologue which, though it retained, in all likelihood, some of Lincoln's words, misrepresented him wholly" (299). He concludes his judgment of Chiniquy with an odd juxtaposition concerning truth and fraud: "the pious and not dishonest fraud of the clergyman went on its exulting road." https://archive.org/stream/mythsafterlincol00illewi\#page/n0/mode/2up 35 https://archive.org/stream/papacycivilpower00thomrich\#page/n5/mode/2up 36 Thompson's stance against the Church did not hurt his political standing - the year after Papacy's publication, he would be appointed by Rutherford B. Hayes to serve as the secretary of the navy. 
${ }^{37}$ Ventura ends his last chapter entitled, "The Secret Plans to End American

Democracy," warning that "we're on the brink of losing everything the founders of our country stood for and bequeathed to us" (200).

${ }^{38}$ On conspiracy theory, see Barkun's A Culture of Conspiracies: Apocalyptic Visions in Contemporary America (2003); Creps's "The Conspiracy Argument as Rhetorical Genre" (1980); Fenster's Conspiracy Theories: Secrecy and Power in American Culture (2008); Knight's Conspiracy Culture: From Kennedy to the X-Files (2000); Goldberg's Enemies Within: The Culture of Conspiracy in Modern America (2001); Melley's Empire of Conspiracy: The Culture of Paranoia in Postwar America (2000); Olmsted's Real Enemies: Conspiracy Theories and American Democracy, World War I to 9/11 (2009).

${ }^{39}$ The exact date for the oath is uncertain - it did feature in a 1913 congressional committee that labeled it a forgery (see Boller \& George 62-63). See also Elbert Hubbard's “A New Disease" (The Arena 10 [June 1894]: 76-83). Hubbard describes a false papal encyclical, widely disseminated, that also spoke of alleged Catholic plots to hurt, harm, and kill America's Protestants:

http://books.google.com/books?id=uotEAQAAIAAJ\&lpg=PA1\&ots=mnN9oPBNjE\&d $\mathrm{q}=$ arena $\% 20$ june $\% 201894 \& \mathrm{pg}=\mathrm{PR} 1 \# \mathrm{v}=$ onepage $\& \mathrm{q}=$ hubbard $\& \mathrm{f}=$ false

${ }^{40}$ Concerning the status of the Catholic Church during the French Revolution (17891799), see A. Latreille's "French Revolution" in the New Catholic Encyclopedia (2003). Although the policies, and their enforcement, along with the governing bodies, varied and changed throughout this period, the Catholic Church did experience significant persecution from anti-clerical elements. The period known as the "dechristianization" (May 1792-October 1794) "involved the deportation of ecclesiastics and the condemnation of some of them to death; the closing of churches, the wholesale destruction of religious monuments and symbols; the prohibition of worship, religious teaching, and propaganda; the secularization of the state and its institutions; and the condemnation of all ancient religious traditions" (972). Priests and other religious persons were killed. For instance, "135 priests were shot to death in Lyons" in November 1793 (973). It should also be mentioned that the persecution was not limited to Catholics; the small Protestant community, too, saw "their churches closed and their services stopped." And from September 1797 to November 1799, "the Directory revived the deportation legislation of the previous period and caused 2,000 priests to be arrested. . . . While waiting to transport them to Guiana, officials herded them into prisons and convict ships ... under conditions so inhuman that many died" (975). ${ }^{41}$ Race could play a role in anti-Catholic rhetoric. In an 1895 address to a national A.P.A. meeting, A.P.A. president W. J. H. Traynor warned of Catholic evangelism among blacks: "the papist negro, like his Irish co-religionist, is a menace to the State, a terror to his neighbor and the curse of his race. If the papacy pursues uninterruptedly for the next ten years her perversion of the colored people of the South, a race war of most terrible proportions is inevitable" (163). Note here also the equating of the Irish with African Americans, recalling, perhaps, how the social-construction of "white." In an Anglo-Saxon dominant culture, not all whites were equally white.

${ }^{42}$ The A.P.A. Magazine here quotes the Fair-Dealer. Unfortunately, it provides no title, author, or any other bibliographic material. In its directory of the "American Patriotic 
Press" (fellow nativist and anti-Catholic publications), it does list The Fair-Dealer from Fairbury, Illinois. In light of the paucity of information available, I have not cited this in my Works Cited page. The quote, which I have given in whole, is available in the A.P.A. Magazine, (published in San Francisco), vol. 2, n. 3, (February 1896), p. 886. Available via microfilm.

${ }^{43}$ Of course, a shared faith (and anti-Catholicism?) did not keep Protestant denominations from dividing over slavery in the days leading up to the Civil War. (My thanks to Bronwyn Williams for pointing this out.)

44 "Because they attempt to unearth hidden forms of control and communication, theories of conspiracy ... depend heavily on the interpretation of half-hidden clues, tell-tale signs, and secret messages" (Melley 16).

${ }^{45}$ This, too, has parallels with other conspiracy literature, in particular conspiracy fiction, where those in power deny the public the truth out of fear of how the public would handle the truth. As an example, see the conspiracy thriller, Capricorn One (1978), in which the American people are not told the truth about the inability of the nation to land men on Mars - a hoax is then constructed so as to preserve the morale of the American public.

${ }^{46}$ The Fehrenbachers describe Chiniquy as having "earned . . recognition as perhaps the biggest liar in Lincoln literature" (98). They give a sampling of two quotations from Fifty Years, and give classify them both as "E," which in their classification system is the lowest possible grade: "A quotation that is probably not authentic" (liii). ${ }^{47} \mathrm{http}: / / 911$ blogger.com/news/2009-05-01/abe-lincoln-conspiracy-theories ${ }^{48} \mathrm{http}$ //www.jfklibrary.org/Research/Research-Aids/JFK-Speeches/AmericanNewspaper-Publishers-Association_19610427.aspx

${ }^{49}$ Here is one section of Kennedy's speech that is used by contemporary conspiracy theorists: "For we are opposed around the world by a monolithic and ruthless conspiracy that relies primarily on covert means for expanding its sphere of influence-on infiltration instead of invasion, on subversion instead of elections, on intimidation instead of free choice, on guerrillas by night instead of armies by day. It is a system which has conscripted vast human and material resources into the building of a tightly knit, highly efficient machine that combines military, diplomatic, intelligence, economic, scientific and political operations."

${ }^{50} \mathrm{http}: / /$ www.youtube.com/watch? $=$ fuiQj1WQzPQ

${ }^{51} \mathrm{http} / /$ www.arcticbeacon.com/greg/headlines/jfks-hiden-agenda-speech-should-beremembered/

${ }^{52}$ For another example of Kennedy's speech used on an anti-Catholic website, see http://www.spirituallysmart.com/jfk.html; see also http://vaticannewworldorder.blogspot.com/2012/10/assassination-of-president-johnf.html

${ }^{53} \mathrm{http} / /$ www.telegraph.co.uk/technology/news/6408927/Internet-rules-and-laws-thetop-10-from-Godwin-to-Poe.html

${ }^{54}$ The Baltimore Plot was an alleged conspiracy to kill Lincoln in February 1861 as the president elect on his journey to Washington D.C. It remains uncertain whether there was an actual conspiracy. Regardless, steps were taken to protect Lincoln. For a recent discussion of the Plot, see.... 
${ }^{55}$ Allegations of Catholicism did play a part in nineteenth-century American politics. The 1856 presidential campaign for John Frémont (the new Republican party's first presidential nominee) was dogged by allegations that he was Catholic. Writing of Democrat party mud slinging, Julie M. Fenster (2007) describes the campaign by innuendo against Frémont: "the country was drenched with the news that John Frémont was a Catholic - a lie that they managed to back up with facts. For instance, though Frémont was a practicing Episcopalian, his father had indeed been a Catholic. And Frémont had been married by a Catholic priest, due to his Protestant clergyman being indisposed at the last minute. In the campaign of 1856, that was more than enough to sustain a scandal that followed the Republican campaign all year. The majority of Know Nothing party members were against electing a president who was even possibly Catholic; the more resolute took just as dim a view of anyone who had been married by a priest. To them, that amounted to a kind of treason, too, and the Anti-Nebraskans [Republicans] undoubtedly lost votes because of it" (158).

${ }^{56}$ According to his sister (published 1938), Asia Booth Clarke, John was baptized into the Episcopal Church (58), participated in Know-Nothing meetings $(71,75,105)$, and was buried according to the Episcopal rite (185). Michael W. Kaufman (2004) describes the religions of the conspirators: "Asia Booth Clarke seemed to have believed her brother had converted to Catholicism, but the evidence is not convincing. Booth and Herold were Episcopalians, Atzerodt was a Lutheran, Arnold and O'Laughlen were Methodists, and Powell was a Baptist. Spangler was German Reformed, but converted to Catholicism" (473, n. 12). Dr. Mudd and the Surratts were Catholic. Even if all the conspirators were Catholic, it would no more prove a Vatican-inspired plot than does the fact that the 9/11 terrorists were all Muslim prove an international Islamic plot. Chiniquy does acknowledge that there were Protestant conspirators; however, he claims that they were actually Catholics who were hiding their faith at Jesuit orders (723-24). Beside Chiniquy's claim, there is no evidence to support the claim that Booth was a Catholic agent. It ignores, for instance, Booth's racism. He was present in the crowd outside the White House for Lincoln's last speech (April 11, 1865). Upon hearing of Lincoln favoring the vote for at least some African Americans, Booth stated, "That means nigger citizenship. Now, by God, I'll put him through” (qtd. in Kaufman 210). Asia Booth Clarke's biography is available here: http://catalog.hathitrust.org/Record/000567161

${ }^{57}$ Murray C. Havens, Carl Leiden, and Karl M. Schmitt, discuss the difficulties involved in their study of assassination: "Not only did we encounter unexpected problems in conceptualization, but we also found that the questions about political assassination were highly complex and difficult" (The Politics of Assassination, 1970, p. xi.). See also Franklin L. Ford's (1985) list of six initial questions (2-3).

${ }^{58} \mathrm{http} / /$ www.theonion.com/articles/november-22-1963,10584/

${ }^{59}$ Ingersoll's charge appears to be exceptional in his work: "In most of the rest of the campaigns of the nineteenth century Ingersoll continued to denounce the Democrats and hold them responsible for whatever he believed to be wrong with the country. But in no other of his published speeches did he blame them for Lincoln's assassination" (Hanchett 93). Ingersoll's speech is available here: 
http://books.google.com/books?id=MoIGAQAAIAAJ\&dq=robert\%20ingersoll\%20wor $\mathrm{ks} \% 20 \mathrm{vol} . \% 20 \mathrm{ix} \& \mathrm{pg}=\mathrm{PR} 1 \# \mathrm{v}=$ onepage \&q\&f=false

${ }^{60}$ Clarke gives a typology of assassins, the first category of which acknowledges that some, such as Booth, were "motivated by political ideals rather than personal deficits as the stereotype claims" (4). However, his other three classifications move "through two shades of mental and emotional disturbance ... to those who are truly mentally disordered."

${ }^{61}$ The constitutional rules of succession provide for a fairly rapid passing of powers to the vice president. Additionally, the executive branch of the United States federal government is more than just the chief executive - the president's cabinet, for instance, would continue to administer their different departments. However, the assassination of the president certainly disrupts the work of the executive branch as it must adapt to a new leader whose agenda and communication style might not totally align with that of the deceased president. Indeed, the debate surrounding President Andrew Johnson's reconstruction policy versus what might have been President Lincoln's illustrates the disruptive power of assassination.

62 "Booth's murder of Lincoln dramatically altered the future of Reconstruction, and of the nation, because it put Andrew Johnson in the Executive Mansion instead of Lincoln" (Leonard [2004] xii). See also Richard Nelson Current's "The Martyr and the Myth: The Lincoln Nobody Knows" in (2010) The Lincoln Assassination: Crime and Punishment, Myth and Memory (217-39).

${ }^{63}$ See Crotty, pp. 5-6, and Bell (2006), pp. 25-27 for overviews of theoretical justifications for assassination, such as an ancient Greek rationalization for ridding a nation of a tyrant.

${ }^{64}$ Available here: http://catalog.hathitrust.org/Record/009420408

${ }^{65}$ An electronic search of the version available on Google Books shows "cowardly" being used 69 times.

${ }^{66}$ Available here: http://arc.stparchive.com/Archive/ARC/ARC01101914p05.php

${ }^{67}$ Charges of assassination remain a part of contemporary anti-Catholic conspiracy rhetoric, with a variety of targets. The 1912 sinking of the HMS Titanic, for instance, becomes a Jesuit plot to assassinate three passengers (Benjamin Guggenheim, Isa Strauss and John Jacob Astor) who allegedly stood in the way of the creation of the Federal Reserve (David Yurchey, "Who Sank the Titanic?" http://www.worldmysteries.com/doug titanic1.htm.) A lengthy post at the popular conspiracy website "Above Top Secret," lists a number of people with connections to 9/11 as Catholic or educated at Catholic schools (LordCarpainter, "9-11: The Jesuit Connection," http://www.abovetopsecret.com/forum/thread381276/pg1). For another site alleging a Jesuit plot behind 9/11 see http://www.thewatcherfiles.com/vatican-ny.html. See also Eric Jon Phelps lengthy e-book/PDF, Vatican Assassins: 'Wounded In the House of My Friends" (2001, 2004), which details allegations of Catholic assassins throughout history.

${ }^{68}$ Woolf seeks to complicate this perception, arguing that "it is wrong to see the world of liberal democracy as an embattled refuge from violence" (56). 
${ }^{69}$ In this perception, "What makes a country a dictatorship is a liability to military coups, show trials, summary executions and death squads, and the regular use of torture and the abuse of human rights" (54). 


\section{CHAPTER FOUR}

\section{FROM PAGE TO PICTURE TO PIXEL:}

\section{THE CONTINUED LIFE OF CHARLES CHINIQUY}

\section{FROM NINETEENTH- THROUGH THE TWENTY-FIRST CENTURY}

Since his antebellum conversion to Protestantism, Charles Chiniquy has been and continues to be a driving force in American anti-Catholicism, one of the nation's most endemic prejudices. In The Wars of the Godly (1928), Reuben Maury states that Catholic historians considered Maria Monk's and Rebecca Reed's books as “the Uncle Tom 's Cabin of anti-Romanism in the United States" (172). Maury, who would win the 1941 Pulitzer Prize for editorial writing, declares Chiniquy's Fifty Years in the Church of Rome the "third masterwork in the nineteenth century's trilogy of hate, and the last really epic volume against Catholicism to have been produced thus far in America." Maury then describes the dissemination of its Lincoln conspiracy theory: "The antiCatholics in rural America have known for years [who killed Lincoln]. They got their information from ... [Fifty Years], either directly or by garbled quotations or extracts" (174). Although they "[o]ften enough ... did not know where the quotations came from, ... they knew the thing must be true because the parson or the anti-Catholic weeklies told them it was" (174). The most famous of Chiniquy's Lincoln statements can be "found in volumes unnumbered of anti-Catholic literature as a verified utterance of Abraham Lincoln" (177). The story of the Catholic plot "was long since blown into a 
cocked hat," he admits, "except in the minds of no one know how many people resident on farms and in small towns of the midwest and southern states" (178). ${ }^{1}$

Although anti-Catholicism has receded from the heights of influence it once had in American culture, it has not entirely disappeared, and is actively present on the World Wide Web. Among the standard "truths" advanced by these webpages is the Catholic conspiracy to kill Lincoln that is Chiniquy's narrative. In this chapter, I argue that the nature and workings of American anti-Catholicism and its use of conspiracy rhetoric, in particular, the place of ethos in what Hofstadter called "the paranoid style," are illuminated by reference to Charles Chiniquy's writings. I demonstrate Chiniquy's importance by looking at how his claim and ethos were used in late-nineteenth-century nativism and twentieth- through twenty-first-century anti-Catholicism. Having established in the last two chapters several significant types of ethos construction used in Fifty Years, in this chapter I examine how Chiniquy's conspiracy tropes and narrative are used in three different genres from three different time periods advancing social, political, and religious agendas. First, I examine the nativistic agenda expressed in the pages of the late-nineteenth-century anti-Catholic A.P.A. Magazine (1895-1897). Aside from the antebellum Know-Nothings and the post-World War I Ku Klux Klan, the A.P.A. was the most noteworthy political expression of anti-Catholicism in American history. Here Chiniquy's text helpfully demonstrates the fluid lines between nativism and anti-Catholicism: though one is ostensibly political and the other doctrinal, in the message of anti-Catholics like Chiniquy, those lines blur. Second, I consider what is probably the largest modern-day publisher of anti-Catholic materials, Chick Publications, and their comic book adaptation of the Chiniquy narrative. In so doing, I 
examine the role of visual rhetoric in disseminating an anti-Catholic message, suggesting that works like Chick's serve as a sponsor of religious, or anti-religious, literacy. Third, I look at Chiniquy's place on the World Wide Web. I compare the distribution problems faced by earlier, print-based mediums (the Gilded Age magazine and the twentieth-century comic book) to illustrate the relative ease of access the Web provides contemporary conspiracy theorists.

In this chapter, I also examine the ends to which Chiniquy's conspiracy narrative and ethos constructions have been used, demonstrating an appropriation of Chiniquy and his Lincoln conspiracy by nineteenth-century nativists and twentythrough twenty-first century apocalyptic fundamentalist Christians. In so doing, I show not only how Chiniquy helps us understand anti-Catholicism and conspiracy theory, but also how the study of anti-Catholic writing can illuminate the nature of certain types of public rhetoric. Throughout, I confirm the importance of ethos in constructing conspiracy rhetoric, the central claim of my dissertation.

\section{Nineteenth-Century Nativism and Chiniquy: The A.P.A. Magazine}

Between the fall of the antebellum Know-Nothing American Party and the rise of the KKK, the late-nineteenth-century American Protective Association (A.P.A.) was the most significant anti-Catholic and nativist organization. ${ }^{2}$ Knobel describes it as "the most attention-getting — and in some ways most potent—nativist organization since the 1850 s" (212). ${ }^{3}$ Although estimates vary on its size, the A.P.A. was, according to John David Rasuch, Jr., (2003), the "largest anti-Catholic organization in the United States during the late 1880 s and $1890 \mathrm{~s}$ " (58). ${ }^{4}$ Its statement of thirteen principles makes 
explicit its aims, which included extending naturalizing immigrants by seven years and opposing for public office any "subject or supporter" of "any ecclesiastical power not created and controlled by American citizens, and which claims equal if not greater sovereignty than the government of the United States of America"- this, in the eyes of the A.P.A., was "irreconcilable with [American] citizenship" ("A.P.A. Principles, As Adopted at Des Moines Iowa, and Readopted at Milwaukee in May 1895" 88). ${ }^{5}$ The A.P.A. and other Gilded Age anti-Catholic organizations used multiple means to spread their message. On June 1, 1894, the New York Times, described the A.P.A. as "secretly circulating its lying literature, ... spreading an 'anti-Romanist' alarm by word of mouth and by circular, through newspapers devoted to the cause, and through its 'lecturers"” ("Degrading Warfare of A.P.A. Forged Incendiary Literature the Favorite Weapon" 1). ${ }^{6}$ Via persuasive lecture and argumentative literature, "word of mouth and circular," the Gilded Age anti-Catholic and nativist movement made their message known. ${ }^{7}$ And one surviving example of this type of literature, one of the "newspapers devoted to the cause," is the A.P.A. Magazine. ${ }^{8}$

The A.P.A. Magazine provides a particularly useful resource for examining latenineteenth-century anti-Catholicism and nativism. Published in San Francisco, California, its purpose, stated by publisher and editor Warren E. Price, was "presenting each month a succinct resume of the best that the patriotic and general press has to say on A.P.A. and allied topics" ("Editor's Innings. Aim of the A.P.A. Magazine" July 1895). ${ }^{9}$ Although it included original material, the A.P.A. Magazine contained a great number of republished items. In fact, this was one of its selling points: "It is the desire of the editor to make its reports so full that a man will not need to take in the entire list 
of patriotic papers, and supplement them with as many more Catholic and general papers, to feel that he has at hand all that every live American should and must read." As an anthology of the contemporary anti-Catholic press, the magazine provides an excellent snapshot of the "patriotic press" of the Gilded Age. As such, the magazine demonstrates a variety of approaches used by late-nineteenth-century anti-Catholic rhetors to spread their message, including speeches, pamphlets, books, fiction, nonfiction, charts, poetry, songs, maxims, illustrations. The message spread by these different means is both political and theological. But within this diverse content, there were repeated themes and messengers, several of which speak to or illustrate the rhetorical heuristics and ethos constructions I have established earlier in this dissertation. This demonstrates, then, the continued relevance of these tropes to the antiCatholic and nativist movements and conspiracy rhetoric.

The Importance of Renegade Rhetoric

Renegade rhetoric is found throughout the A.P.A. Magazine, with a number of references to and articles by former members of the Catholic clergy. ${ }^{10}$ For example, the six issues that make up the first volume (June-November 1895) feature a letter by Evangelist Thomas Leyden to the editor of the anti-Catholic weekly The Citizen (Eureka, California), defending the use of ex-priests (June 1895, 63-65); lectures by expriest Joseph Slattery (July 1895, 153-57; August 1895, 280-84); a defense of the exnun Margaret Shepherd, reprinted from the anti-Catholic weekly, the Toledo American (September 1895, 346); and a plea from ex-priest P. A. Sequin for funds to construct a home for ex-priests in Wisconsin to replace the home Chiniquy had built, the alleged 
victim of Catholic arson (October 1895, 437-38). Issues four through six each advertise a variety of ex-cleric books for sale by the A.P.A. Magazine, including Maria Monk's Awful Disclosures, Mrs. Slattery's Convent Life Exposed, Edith O'Gorman's Convent Life Unveiled, ex-priest Kostello's Convent Horrors and Secrets of the Confessional, ex-priest Rudolph's The Great Roman Anaconda, and Joseph Slattery's Secrets of Romish Priests Exposed. ${ }^{11}$ All of these, it should be mentioned, are "specially recommended" by the A.P.A. Magazine, and all of them together show the popularity of the genre on the printed page.

The testimony of these religious renegades, however, did not come without critique. ${ }^{12}$ There were those even within the American Protective Association who frowned upon at least some of the ex-clergy, arguing against their use as A.P.A. lecturers. At the 1894 Iowa A.P.A. convention, outgoing president Osceola B. Jackman denounced them: "The average ex-priest is simply a leech, sucking the life-blood of the councils for his own enrichment" (qtd. in Kinzer 113). He then broadened his critique, condemning them for their religious attacks: "We claim in our principles that we attack no man's religion and make no warfare on the religious tenets of the Roman Catholic church, and yet we hear these ex-priests abuse all the peculiar observances of this church, and vilify and make fun of its observances. We thereby stultify ourselves and bring reproach and dishonor upon the order and its principles." ${ }^{.13}$ The Iowa convention adopted a resolution calling for the national convention to ban ex-priests. Indiana would follow suit, as would the national convention (Kinzer 118, 122); however, the national convention would also choose ex-priest George Rudolph as a lecturer, "demonstrate[ing]," Kinzer remarks, "how seriously the delegates took the resolution on 
the use of former priests" (123). ${ }^{14}$ Indeed, as Kinzer points out, there was very little the A.P.A. could do to prevent ex-priests from speaking: there were many options among anti-Catholic organizations from which they could seek sponsorship, or they could act on their own (Kinzer 113). As Slattery truthfully states in rebutting the resolution, "expriests lectured before the A.P.A. clique existed and will lecture after its death" ("ExPriests and the A.P.A.” 763). But if some saw them as leeches, others defended them as experts, whose knowledge was invaluable in the fight against Rome. After all, an expriest was one who could "faithfully warn[ ] the American people, as only a man can warn them who has had an inside view of what Rome actually is" (E. E. F. "Maligning Converted Priests. Is It Patriotism or Disguised Jesuitism?” 75). If others maligned expriests, the A.P.A. Magazine defended and used them. And one of those defended and at times lionized was Charles Chiniquy. ${ }^{15}$

The A.P.A. Magazine begins and almost ends with Chiniquy. The cover of the first issue features the Lincoln prophecy: "I do not pretend to be a prophet; but, though not a prophet, I see a very dark cloud on our horizon, and that dark cloud is coming from Rome. It is filled with tears of blood" (June 1895). And though not attributed to Chiniquy, the second and fourth issues (July and September 1895) also feature quotes from Fifty Years on their covers, with September's being from Chiniquy's Lincoln: "The Pope and the Jesuits are the only organized power in the world which have recourse to the dagger of the assassin to murder those whom they cannot convince with their arguments or conquer with the sword.” The last issue (3.9 June 1897) reprints an 1878 letter from Chiniquy describing Rome's plans to dominate America's cities via 
Irish immigration; the article begins with the editorial note, "Written almost twenty years ago-Events of to-day verify Chiniquy's prophecy” (55) (“Capturing American Cities" 55-58). In between the first and the last issue, Chiniquy is a frequent feature. $\mathrm{He}$ is sometimes referenced in passing, such as in a letter to the editor (September 1895) where a Wisconsin reader writes, it has been a "few weeks since 'Father' Chiniquy said in his speech in Boston: 'If you do not kill Rome, Rome will kill you"' (Collins 401). And there are places where he is written of briefly, such as in "A Question of Veracity" (February 1896,922 ) which describes a Catholic challenge to a Chiniquy quotation of a British prime minister featured on the magazine's second cover. ${ }^{16}$ Chiniquy also is the focus of longer essays, with the longest being an excerpt from Fifty Years, "President Lincoln's Assassination Traced Directly to the Doors of Rome" (November 1895, 547$61) \cdot{ }^{17}$

Chiniquy is set forth as a man of character, one who can be trusted. For instance, Price uses his editor's page to introduce the author of the "famous" Fifty Years, stating, “Chiniquy's claims are never denied outside of Rome and his word is as good as pure gold” (“Shop Talk,” November 1895, inside cover). C. W. Romsar, introduces a summary of Chiniquy's life (based on Fifty Years), describing him as one in whom "[t]he reader can rely upon the perfect correctness of every word" (1555). Using the ethos of association, Chiniquy is also connected to Lincoln. "Between" Chiniquy and Lincoln "a warm attachment sprang up" (“President Lincoln's Assassination Traced Directly to the Doors of Rome" 547). Ex-priest Seguin tells readers that when they read Fifty Years they "will find that he was trusted by the greatest American who ever lived, Abraham Lincoln" (761). Further, an association takes place between the two in the 
magazine's advertisement section, where not only Chiniquy's Fifty Years is sold but also his "Assassination of Lincoln." 18 The magazine also circulates Chiniquy’s appropriation of Lincoln's ethos for the anti-Catholic cause by publishing the martyred President's alleged anti-Catholic words. And so the September 1895 issue's "Patriotic Utterances of Patriotic Men" features anti-Catholic quotes attributed to a variety of national heroes, including Grant, Sherman, Clay, and Lincoln (367). ${ }^{19}$ It should be pointed out that the Lincoln conspiracy story and quotations take on a life of their own, divorced, at times, from Chiniquy. He is not always acknowledged — or perhaps even known by the different authors and readers - as the source. In essence, the Lincoln story and quotes become memes. Indeed, this points to the power of the ethos of appropriation: what matters are the person of cultural power, prestige, and cachet, and what he or she has to say. Chiniquy counts, but his significance pales in comparison to Lincoln. Ultimately, what matters is not that Chiniquy heard what Lincoln said, and thus the quote should be attributed to him; what counts is what Lincoln said and that it was Lincoln who said it.

Whether or not Chiniquy is cited as a source, the ethos of assassination is present throughout the A.P.A. Magazine, which is not surprising given the relative proximity in time of the Civil War and Lincoln's murder. ${ }^{20}$ The very first issue, for instance, features at least four references in four different articles to Catholic involvement in the assassination. "The Moral Code of the Jesuits" lists multiple putative quotations from Jesuits sources, including one justifying the murder of a tyrant. The anonymous compiler and author comments, "Mrs. Surratt and Booth regarded President 
Lincoln as a tyrant," thus implying Catholic approval for their actions (23). In an essay reprinted from the anti-Catholic weekly Patriotic American (Detroit, Michigan), Frank Lindon ends his "The Pope's New Departure in American Politics" by listing fifty-two points condemning the Catholic Church, with number twenty six being "its assassinations of Presidents Lincoln and Garfield and of [Chicago] Mayor Harrison" (39). The assassination trope, as can be seen here, was not limited to Lincoln (or to presidents). "The Moral Code of the Jesuits" had also claimed Jesuit involvement in Garfield's death - “papist Guiteau 'removed' with a bullet purchased by Jesuit money"- and an attempted death plot against President Washington: "Patrick Hicks, papist, attempted to kill George Washington by putting poison in the General's soup, during the Revolutionary War" (23). ${ }^{21}$ In a speech reprinted from the "patriotic" weekly American Citizen (Boston, Massachusetts), W. H. Lannin speaks of the case for a Catholic conspiracy against Lincoln as clearly proven: "Unimpeachable students of our country's past history have proved that when a heroic patriot—even an Abraham Lincoln — dared to stand up in defense of national Protestant liberties against the revolutionary spirit of Jesuit craft, the leaden missile took him out of their way" (48). And reprinted from the anti-Catholic weekly Chicago American (Chicago, Illinois) is "Rome's Inquisition. It Was Not More Terrible In The Dark Ages Than It Is To-Day." Written by Justin D. Fulton, a Baptist minister and Know-Nothing who served also as an A.P.A. lecturer, the article suggests that a plausible case can be made that Rome will eventually master the United States. ${ }^{22}$ After all, " $\$ 13,000,000$ has been given to Rome by Congress since Abraham Lincoln was assassinated, by Catholics" (57). These examples demonstrate not only the power of the assassination trope but also the 
continued importance of the traumatic War Between the States and the tragic death of the union's savior. In attempting to explain these unthinkable events, writers settle blame upon a foreign other: the Italian Vatican or the Irish immigrant.

Blurring the Lines Between Anti-Catholicism and Nativism

In Chapter One, I cautioned against conflating anti-Catholicism with nativism. One could be, for instance, a Catholic nativist (think here of a nineteenth-century American Catholic opposed to Chinese immigration). However, though they are not the same, in the American historical context, the line between nativism and antiCatholicism is fluid. And the A.P.A.'s appropriation of Chiniquy and other ex-priests demonstrates the blurry demarcation between nativism and anti-Catholicism. Les Wallace (1990) claims that Chiniquy "toured as an A.P.A. lecturer" (54), and Lougheed (the most prominent contemporary Chiniquy scholar) mentions that " $[\mathrm{s}]$ everal polemical Catholic pamphlets affirmed" the same (168); however, Lougheed remains skeptical, pointing to a lack of supporting proof by the pamphlets (Wallace, too, does not cite a source for his claim). ${ }^{23}$ Chiniquy, as Lougheed points out, had as a Catholic (and an immigrant) naturally opposed the Know-Nothings in the $1850 \mathrm{~s}$. But in the Gilded Age, he was now a Protestant, deeply opposed to the Church. Lougheed argues that while Chiniquy certainly "approved of the A.P.A. initiatives in general," as he "[f]avoured political initiatives to block Catholic power," the relationship between the A.P.A. and the ex-priest are at best "minimal" $(168,169)$. Regardless, though, of whatever formal relationship Chiniquy had with the A.P.A. or any other nativist organization, his rhetoric was such that it could easily be used to defend nativist 
positions, for his attacks on the Church were not solely religious or theological; they were also political. For instance, in Fifty Years Chiniquy's Lincoln broaches the idea of denying constitutional rights to Catholics: "Till lately," Lincoln allegedly states, "I was in favor of the unlimited liberty of conscience, as our constitution gives it to Roman Catholics. But now, it seems to me, that soon or later, the people will be forced to put a restriction to that clause towards the Papists" (704-705). Fifty Years is a political document. Certainly its conspiracy theory about the murder of an American president has major political ramifications, which is why Gilded Age and later anti-Catholics would use it during elections. For example, the October 31, 1890 Los Angeles Herald condemns leaflets with which Los Angeles is being "deluged" "“A Despicable Device" 4). ${ }^{24}$ The flyers relate Chiniquy's Lincoln conspiracy theory and list Roman Catholics (both Democrat and Republican) running for state office, with the obvious point being that one should not vote for a Catholic (given Catholicism's infamous record). Voting, a political act, is thus clearly tied to a religious faith—and an ex-priest's conspiracy about a deceased American president is the basis upon which a ballot should be cast. Chiniquy did make arguments that, if not nativistic, certainly lent themselves to the nativist campaign. Twice the A.P.A. Magazine printed a letter from Chiniquy (September 1, 1878) alleging a papal plot to dominate America by controlling its cities through Catholic —in particular, Irish—immigration. Chiniquy claims to have been present at an 1852 meeting of priests in which the urban conquest strategy was laid out. "Silently and patiently," he quotes the priests as saying, "we must mass our Irish Roman Catholics in the great cities" ("Capturing American Cities" 55). The priests, acting under the guidance of bishops, describe the end of their multiplying Irish voters, "with 
our outnumbering votes, we will turn them [i.e., city-dwelling Protestants] out, and forever, from every position of power, honor and profit!” The titles of the articles containing the essay are telling: "The Pope's Irish in American Politics” (Madison C. Peters November 1895) and “Capturing America’s Cities” (June 1897). The first title calls explicitly to mind the fear of Irish (foreign) immigration while the second speaks to the fear of Catholic dominance in America's expanding urban areas. This particular narrative had appeal outside of the A.P.A. Magazine — it had been printed earlier by the Loyal Women of American Liberty, evidently another "patriotic" organization, under the far less arresting title, "Mr. Chiniquy in California." ${ }^{25}$ Chiniquy himself incorporates the letter into Chapter 59 of Fifty Years, the short title of which is "Rome, the Enemy of the United States" (pp. 668ff.). ${ }^{26}$

In defending ex-priests to the A.P.A., Slattery spoke of Chiniquy’s pivotal role. Along with another ex-priest, Bishop McNamara, Chiniquy "worked hard for years" and "prepared the people for the present moment." "Their work," writes Slattery, "was the root of the A.P.A.” Indeed, Chiniquy's language and arguments were ones that a nativist could easily appropriate, but his usefulness for the nativist cause is more than just his phrasing. Even the doctrinal substance of his anti-Catholic message lent itself to a nativistic 'othering' of immigrants, in which Irish immigrants become the Pope's army, a swarm under the spiritual control of an Italian pope to invade and take over national control, city by city, of the United States. For from constructing the Church as a foreign and dangerous other, it is an easy step to seeing its practitioners as foreign and dangerous, and thus in need of the political controls promoted by groups such as the A.P.A. Anti-Catholic nativists saw the Church not as or only as a religious 
organization - they saw it as a political force, one that used faith to bring about submission. Hence, they would quote Catholic hierarchs about the Church having power over all aspects of a Catholic's life, including their vote. If one were a good Catholic, one did what the Church said, and the Church did not limit itself. When antiCatholics opposed the Vatican they were not only opposing the seat of the Catholic faith but a state with diplomatic relations with nations. Indeed, Chiniquy's central plot is a political one, focusing on the political murder of an American president. The way that Chiniquy and other ex-priests constructed their argument, at least in part, as an attack on the soul of the nation (as well as an attack on the souls of individuals) shows that they were making both a political and a theological attack. And part of that attack focused on those groups they saw as invading the nation, being under the sway of a pope bent on using them to achieve national aims by threating spiritual destruction. And this is how the line between anti-Catholicism, a seemingly religious movement (though not a religion), blurs into nativism, a seemingly political movement (though at least in the case of the A.P.A., not a political party). The polemic of anti-Catholicism served the public rhetoric of political nativism-a blurring of the religious and the secular that remains a presence in contemporary American politics. Ultimately, the A.P.A. Magazine and other anti-Catholic and nativist organizations associate Chiniquy with Lincoln and use Chiniquy's appropriation of Lincoln's ethos to engage in the ethos of character assassination of the Catholic Church.

\section{Twentieth- and Twenty-First-Century Anti-Catholicism: Jack Chick's Comic}

\section{Attacks}


With "500 million copies of his 142 books in print, including translations in more than 100 languages," Christian fundamentalist publisher Jack T. Chick may be, as Robert Ito (2003) claimed, “the world's most published living author" (56). ${ }^{27}$ Known for their distinct artistic style, Chick's seemingly ubiquitous religious pamphletsChick Tracts—are small, brief, cheap, black-and-white pamphlets covering and touching on a wide variety of topics, including Mormonism, Islam, Jehovah Witnesses, Masonry, Halloween, homosexuality, evolution, global warming, drugs, alcohol, STDs, gangs, and the occult. ${ }^{28}$ Chick's literature is deeply conspiratorial; the University of Chicago's Dan Raeburn (1998) calls Chick "the Thomas Pynchon of fundamentalists" (4) ${ }^{29}$ With its frequent focus on an alleged global Roman Catholic conspiracy, Jack Chick's Chick Publications is perhaps the most prominent modern-day anti-Catholic publisher. ${ }^{30}$ Michael Ian Borer and Adam Murphee (2008) call his work, "arguably one of the most successful contemporary attempts to construct Roman Catholicism as a social problem" (96). ${ }^{31}$ And among his anti-Catholic works is a comic book adaptation of Charles Chiniquy's Fifty Years in the Church of Rome, featuring on its cover Lincoln's assassination, with the Vatican in the background, under the title The Big Betrayal. $^{32}$

Using Chick's work, in this section, I consider the importance of Chiniquy for understanding contemporary anti-Catholicism. In particular, I examine the role of the visual in anti-Catholic conspiracy rhetoric, looking at how ethos is constructed visually. In light of his comic introducing readers to the Chiniquy story by a cover displaying the president's death, I begin by focusing how an ethos of assassination is created. I then consider the continued appeal of renegade rhetoric not only in Chick's use of Chiniquy 
but also in his publication and dissemination of another alleged ex-priest, Alberto Rivera, whose story uses similar tropes to those of the Chiniquy narrative. But a comparison of the Chiniquy and Rivera stories also reveals differences - in particular, the place of apocalyptic and dispensationalist rhetoric in contemporary Christian-based conspiracy narratives. I conclude by suggesting how Chick's work acts a literary sponsor - a literary sponsor of prejudice.

\section{A Visual Rhetoric of Fear}

In examining Chiniquy via Chick's comics, we enter the realm of visual rhetoric. ${ }^{33}$ When compared to prose, pictures at times are denigrated as a lesser form of communication. Barbara Maria Stafford (1996) writes of a "distorted hierarchy" that "ranks the value of reading above that of seeing" (3). ${ }^{34}$ Though belittled by some, “[p]eople of all kinds," writes David Morgan (1998), "take illustrations seriously." Visual Piety, Morgan tells the anecdote of a listener to a radio call-in program challenging the use of makeup as unscriptural, pointing to the biblical story of Queen Jezebel: "'Could you point out where in the text it talks about makeup?' the radio host asked. 'Well, it isn't actually in the text, but the illustration on page 89 ...' (1). People take visuals seriously, as Morgan argues, "because an illustration, as the word suggests, is supposed to illuminate the proper meaning of the accompanying text" (although in the case of the anti-cosmetics caller, "the illustration supplanted the text by providing a meaning the viewer felt ought to be found there"). Historically, as the caller also illustrates, people take visuals seriously when it comes to the religious and the spiritual. ${ }^{36}$ For though the word might have been in the beginning, it was closely 
followed by the visual—in the biblical account of the Jewish exodus from Egypt, the Ten Commandments were placed in a gold-covered ark with two cherubim resting on top. In the United States, according to Jason C. Bivins (2008), “American Christians have regularly engaged their culture by using the pictorial register as well as the textual" (43). ${ }^{37}$ But part of that engagement has not only been with the culture at large but also with each other. The history of the Protestant/Catholic division, both in the United States and elsewhere, has been one long characterized by arguments both prose and visual. ${ }^{38}$ Maria Monk's Awful Disclosures, for instance, featured a map of the convent grounds. ${ }^{39}$ Or consider Thomas Nast's famous—or infamous—-1875 depiction in Harper's Weekly of Catholic prelates in crocodilian form about to attack American school children and the American system of public education ("The American River Ganges"). ${ }^{40}$ In so doing, believers tapped into the power of visual rhetoric.

In rhetorical studies there has been a visual turn. ${ }^{41}$ Charles A. Hill and Marguerite Helmers preface their (2004) Defining Visual Rhetorics stating, "A few years ago, we noticed a major shift in the field of rhetoric, one in which an increasing amount of the discipline's attention was becoming focused on visual objects and on the visual nature of the rhetorical process" ("Preface" ix). ${ }^{42}$ Mary E. Hocks (2003) acknowledges that though visual rhetoric, which she broadly defines as "visual strategies use for meaning and persuasion," is not a new development, "its importance has been amplified by the visual and interactive nature of native hypertext and multimedia writing" (629). However, the rhetorical power of the visual is not limited to the present day or the net; Jens E. Kjeldsen argues that classical rhetoric was "a visual 
discipline, $\ldots$ an art imbued with visuality" $(133) .{ }^{43}$ In religious and non-religious visuals and multimodal texts, arguments are being made. ${ }^{44}$ And in these arguments, the visual can make a case differently, perhaps more effectively, than the verbal. "The advantage of visual arguments over print or spoken arguments," writes J. Anthony Blair (2004), "lies in their evocative power" (51). Blair also points to the "sense of realism" projected through images: "My students . . . tell me that television news is better than print news in the respect that with television news they can see for themselves." The power of the visual can contribute to a text's or an author's ethos. ${ }^{45}$ Valerie J. Smith (2007), writes, "In a speech, a rhetor's ethos includes visual aspects such as appearance and manner of delivery" (120). Blair illustrates with advertisements for medical products featuring "actors dressed in white lab coats with a stethoscope around their necks" (54). Here the appeal to ethos is based, in part, on clothing: the stethoscope and white lab coat are associated with the ethos of medical authority, giving the ad a certain level of perceived credibility. Blair also points to television network newscasts being filmed in front of places associated with power, such as the White House or United States Capitol Building. Via a visual association, a certain level of authority is gained for the reporter: "The backdrops are visual rhetoric devices that render the message conveyed more believable or persuasive. They lend ethos to the reporter" (58). The point can be seen even by contrast: imagine a CNN anchor reporting on the State of the Union address with a Taco Bell as the background.

The cover of Chick's Big Betrayal also uses its background to make an ethos construction; however, this is the ethos of assassination. ${ }^{46}$ The cover of a comic is a paratextual place of importance; it is created, as Dale Jacobs (2013) points out, "with 
the purpose of creating interest in the comic that will then lead to its purchase" (24). And for his adaptation of Fifty Years, Chick uses Lincoln's murder as the gateway into Chiniquy's narrative. From the left, center side of the comic book's front cover, a hand is extended, holding a pistol, smoke curling up the right side of the page. In the lower right hand section, hardly in the frame, is the target of the escaped bullet. Although barely seen - a dark coat, a white collar, brown hair, an inch of exposed neck - the reader grasps that this is another visualization of the iconic moment of America's tragedy, for as the narrative within will reveal, the hand is Booth's and the target, Lincoln. This is what we as a culture know. But behind Booth's bullet and Lincoln's slumping form lie visual elements not commonly tied to Lincoln's assassination by contemporary Americans. Against a gold and white background evoking the Vatican flag, lays the iconic structure of Roman Catholicism: St. Peter's Basilica. The cover thus clearly connects the Church to violence - the largest visual elements on the page are the assassin's hand, the basilica, the Vatican's flag colors, and the smoking gun. And though he may be barely on the page, the violence, in this case, is against an American president. For while it might have been an actor who pulled the trigger, in Jack T. Chick's resurrection of Chiniquy's old allegation, the directors of that Good Friday night's tragedy were Jesuit priests.

The ethos of assassination continues throughout the comic. Following the lines of the Fifty Years narrative, the Church is portrayed in violent terms. ${ }^{47}$ Since the reader is drawn to the comic with the cover of a smoking bullet and a slumping president, perhaps it is not surprising to find the story framed by violence against the main character who turns out not to be the sixteenth president but a now obscure Catholic 
priest turned Presbyterian pastor. With cries of "Kill him!," "You devil!," and "Don't let him get away!," along with the requisite sounds of cartoon fights_-"Whack," "Ungh," and "Yaaah!"- Jack T. Chick introduces readers to Chiniquy (1). In fact, the comic bookends violence against Chiniquy with both beginning and ending pages featuring mobs bent on killing him $(1,64)$. (The mob violence provides a dramatic entrance and exit from the narrative, helping to initially hook a reader and then to leave a reader with imagery connecting a supposedly Christian church to irrational religious fanaticism.) Here, too, it should be noted, there are elements of an ethos by association. Through graphic violence Lincoln and Chiniquy are associated together against a church bent on killing them - the violence on the cover against the president is also arrayed against the pastor, and though the Big Betrayal's story is Chiniquy's, the cover belongs to Lincoln. ${ }^{48}$ Violence punctuates the narrative, with priests bursting with fury $(10,28,29,36,41,42,46)$, an alcoholic mother covered with the blood of the daughter she accidentally killed (23-24), and of course, the murder of Lincoln (58). The violence can have an almost comic tone, such as the inclusion of a Catholic "fable" about a decapitated head resurrected to tell Catholics to pray the rosary and avoid Purgatory; but even here the comedy is a gallows humor at the Church's expense. The violence in The Big Betrayal reflects a violence found throughout Chick's work: it “falls squarely in the horror genre" (Bivins 84).

Chick's use of violence in retelling Chiniquy's story perhaps demonstrates how certain elements of ethos construction lend themselves to visual representation, with the trope of assassination being particularly open to graphic depiction and appeal. ${ }^{49}$ Indeed, whether visual, verbal, or some combination, the ethos of assassination is connected to 
the powerful rhetoric of fear. ${ }^{50}$ In his (2000) Scare Tactics: Arguments that Appeal to Fears and Threats, Douglas Walton describes three fundamental qualities that make up a "fear appeal argument," all of which can be used in multimodal genres like comic books, with their interplay of images, dialogue balloons, thought balloons, and narrator boxes. Walton lays out the fear appeal's elements as follows: “(i) it cites some possible outcome that is fearful to the target audience, (ii) in order to get that audience to take a recommended course of action, (iii) by arguing that in order to avoid the fearful outcome, the audience should take the recommended course of action" (qtd. in Pfau 219). Rather than just being the purview of individual anxieties or phobias, this type of appeal to fear has affected the socio-political realm; it has been a politically popular argument. Michael William Pfau (2007) states that "the history of republics reveals a political discourse rife with appeals to fear" (216). As an example, the nativist movement used the fear appeal of foreign immigration in large cities dominating nativeborn, white, Protestant hegemony to advance their goals of limiting immigration and extending the naturalization period. Indeed, the rhetoric of fear can be an effective means of persuasion: "fear's history reveals its impacts not only on individuals, but on entire communities, economies, and political systems." It also affects religion and religious discourse, which is certainly evident in Chick's case ${ }^{51}$ Bivins argues for an "erotics of fear" at work in Chick's comics, which he defines as "the desire or fascination with that which is condemned or consigned to the realm of darkness and demonology" (17). Bivins describes Chick's work "as a whole constitute[ing] a detailed catalog — filled with exclamatory depictions — of sin, leading to a fateful choice where one either converts (in brief and without much detail) or burns (at length and in 
great detail" (84). Like Chiniquy before him, Chick does this for evangelistic reasons: "For heaven's sake," writes Bivins, "Chick becomes a cartographer of hell" (56). Indeed, Chick uses the ethos of assassination to draw the reader to salvation: he uses the fire of Booth's gun to save people from the devil's brimstone. Chick draws readers in with the cover, and then places them into the story's tension by means of the words and images on the first page. A crowd is trying to kill a Protestant Chiniquy. One member of the mob is singled out. He holds a knife and screams, "Kill him!" (1). Though the character is referring to Chiniquy, his hate-filled gaze is aimed in the reader's direction. The point is not subtle: they are out kill you, too. In a caption at the bottom of the page, Chick warns readers that their reading itself is in jeopardy. The dark forces attempting to knife, club, or shoot a pastor are still at work today: "There are forces at that would stop at nothing to keep this message from falling into your hands. Read it carefully. Only God knows how many copies of this book we will be able to print." The last page of the narrative returns to another screaming mob, yelling for Chiniquy's death. Here, Chiniquy's back is toward the reader, and the crowd is running at the reader. The narrator raises the question of whether Rome has changed its way from its riotous past in Chiniquy's time. The answer comes from a successor to Chiniquy—-the ex-priest Alberto Rivera, who tells readers bluntly, "No" (60). Indeed, according to Rivera, "Rome still controls governments of the world through her Jesuits and her intrigues." And lest someone think that what was depicted on the cover was a one-time event, Rivera adds, "The U.S. is still her [Rome's] target and she [is] still participating in the assassination of world leaders who do not go along with her." And what are readers to do? They must reject Catholicism and accept Christ. On the inside of the back cover, 
they can look to two models for emulation: Charles Chiniquy, who though a "devoted" priest, was a member of "false church," and "only when he found Christ was he saved"; and Abraham Lincoln, who at Gettysburg, found "the living Christ and gave his heart to Jesus." He may have lost his life to a Catholic bullet, but Lincoln found eternal life through a Protestant gospel. And so, through a sinner's prayer, asking "Jesus into your life to become your personal savior," may you. The visual elements here are small, dignified images of Lincoln and Chiniquy, but the emphasis is textual. The audience is asked to read about Lincoln and Chiniquy's decision to be saved with a view to their own repetition of a printed prayer for salvation. They then record their decisionpositive or negative - with two check boxes featuring the simple binary of "yes" or "no" for the question, "Did you accept Jesus Christ as your own personal savior?" A blank line upon which they should fill in the date of their decision follows their choice. In so constructing this last page, the comic invites the reader to become like Chiniquy and Lincoln— to reject the Catholic Church and to accept Chick's Christ. Indeed, by asking the audience to fill out a form, the reader becomes a part of the page. He or she joins the story.

\section{Chiniquy Revived: Renegade Rhetoric and Alberto Rivera}

In Chapter Two, I examined Fifty Years by means of a five-fold heuristic for understanding conspiracy rhetoric: crusader, victim, expert, visionary, and outsider-onthe-inside. As The Big Betrayal is an abridgement of Fifty Years, it comes as no surprise to find these elements repeated in comic form. And indeed the comic version of Chiniquy has an ethos constructed along similar lines. In the space of sixty-four pages, 
Chiniquy is portrayed as a crusader against Rome $(1,64)$ and for temperance $(8,25-26)$; a victim of Catholic violence (1, 28, 36-38, 40-47, 60-61, 64); an expert in Scripture and Catholicism $(2,16,20-21,54)$; led by God's voice to leave the Church $(16,18,20,21$, $35,63)$; and, in effect, a nascent Protestant while still a Catholic $(2-3,12,15,16,18-19$, 20-21, 25-26, 29, 60, 62). In so constructing Chiniquy, I would argue, The Big Betrayal confirms the continued appeal in conspiracy rhetoric and contemporary antiCatholicism of the rhetoric of the renegade. But Chick demonstrates the continued appeal of renegade rhetoric, not only with his work on Chiniquy but also with his work on Alberto Rivera.

The focus of six, thirty-two page comic books published by Chick over a decade (1979-1988), Rivera (1935-1997) is an alleged ex-Jesuit priest: in terms of the narrative he tells, he is a modern-day Maria Monk (or Charles Chiniquy) ${ }^{52}$ As his story is told through Chick's comics, Rivera is a priest who, like Chiniquy, has an insider's view of the Catholic Church—and what he sees, eventually, leads him to leave. In the first of the comic-book series, Alberto (1979), Rivera describes his education as a priest, being told in graphic detail about the horrors of the Inquisition, in which he claims $68,000,000$ people were victims (16) ${ }^{53}$ For anti-Catholics, the Inquisition is never really in the past—it is always a present worry for a future revival of the Holy Office. He reveals that the Vatican has a "huge" computer with "the names of every protestant pastor ... and every church member in the world including Roman Catholics," by means of which the Church will to institute a new Inquisition in some apocalyptic future dystopia (20). Rivera relates his own role in the Church's persecution, claiming to have been sent to infiltrate and destroy Protestant churches, ministers, and schools. ${ }^{54}$ Eventually, having 
lost his faith but knowing too much, he faces his own persecution. The Church "[t]hrough severe discipline ... tried to change my mind" (29). Sent to a "secret place for priests who have gone insane," Rivera is denied food and water, drugged, and given shock treatments. No longer able to breathe on his own, he is placed in an iron lung. But it is here that he is converted, healed, and inspired to evangelize Catholics.

While he evangelizes Catholics, Rivera warns Protestants: using any and all means, no matter how seemingly improbable, the Catholic Church is out to get you. In comic book after comic book, Rivera paints a church guilty of massive conspiracies. A survey of all six comics reveals that the Church is behind the rise of Hitler and Mussolini, Nazism and Communism; the Ku Klux Klan (started by Catholics); The Protocols of the Elders of Zion and Mein Kampf; World War One; the murder of the Russian royal family; the origin and rise of Islam; the Jonestown Massacre (Jim Jones was a Jesuit, and this was a Catholic plot to discredit Protestant churches); and the observance of Christmas (a pagan-turned-Catholic holy day). The fifth comic, Four Horsemen, the cover of which depicts a pope and a priest riding two of the four infamous horsemen of the book of Revelation, features a chart connecting the Vatican (via the Jesuits) to some of the biggest bugaboos of modern conspiracy theorists: the Masons, the Council of Foreign Relations, international bankers, the mafia ("the criminal arm of the Vatican"), the Club of Rome, Opus Dei, the New Age movement, and the Illuminati (30). This weaving together of so many disparate theories might suggest an openness for those who believe one conspiracy theory to believe others; perhaps accepting one meta theory allows an easier acceptance of others. Although antiCatholicism in the American context has had a strongly nationalistic element, with the 
fear of a foreign other, Rivera's meta and mega conspiracy might be indicative of a changing world condition, resulting in a globalization in conspiracy theory. ${ }^{55}$ In Chiniquy's day, the concern was foreign immigrants coming through Ellis Island to a distinct nation state. But in Chick and Rivera's day, the concern is the Soviet bloc and the Middle East, hence, the connections between the Church with the rises of communism and Islam. ${ }^{56}$ Intertwined in Rivera's global conspiracy charges are Charles Chiniquy's.

As one might expect in ex-priest literature, there are connections between the two men's narratives and conspiracies. Rivera certainly demonstrates several of the five ethos constructions I discuss in Chapter Two, including that of being a crusader, a victim, and an expert. For instance, like Chiniquy, Rivera displays a nearly precocious expertise of Scripture and Catholicism when, as a seminarian, he bests his Catholic teacher over the question of whether the Apostle Peter was the first pope (Alberto 1314). ${ }^{57}$ But Alberto does portray Rivera as having serious questions about Catholicism from his initiation at age seven to a seminary (1), through the death of his mother (2-6, $10)$, and at other points in his life as a seminarian and then priest (11-12, 13-14, 27-28, 29). He thus provides readers a model for doubt - he can raise questions for which they want answers. Although doubt may be the common binary opposite of belief, in the world of anti-Catholicism, the Church itself is the opposite of faith, making doubt in it the potential first step toward Protestant salvation. Although he may not have always been a Protestant at heart, Rivera definitely claims insider status. He provides Chick with a modern-day Chiniquy: an ex-priest, who has seen the inside and been privy to the inner workings of the conspiracy. But in some ways, Rivera can claim an even more 
intimate view than Chiniquy, having allegedly been educated in Vatican trickery by none other than a cardinal who schools him in the true history of the world—one largely determined through Catholic plots: "For three years I was briefed by a brilliant German Jesuit, Augustin Cardinal Bea [1881-1968]. He gave us top secret information. It was a view of historical events that will NEVER appear in the history books" (The Godfathers 3). In addition to being taught by a prince of the church, Rivera is given access to an immense depository of knowledge underneath the Vatican itself. In tunnels "which fanned out for miles in all directions three stories deep beneath the Vatican" is the Church's "nerve center." Here is "information . . . stored . . . for centuries, from the darkest secrets of history up to the secrets of the most sophisticated weapons of the $20^{\text {th }}$ century, gathered from all nations and supplied by Roman Catholics working in ... governments worldwide" (Four Horsemen 7). Rivera uses this moment to attack the Catholic sacrament of confession, alleging that the secrecy of the confessional is violated in order to provide the Vatican with information: "Input from confessionals pours in from even the remotest parts of the world... [sic] giving the Vatican a constant flow of information on social, religious, military, political, educational, and intelligence matters." It is to these miles and miles of underground files, beneath the Church of Saint Peter, that Rivera has access giving him even more knowledge, and thus a greater expertise, that even Chiniquy. If you believe Chiniquy, how much more so should you believe Rivera.

Chick connects Rivera and Chiniquy by using each to support the other's charges. ${ }^{58}$ In The Big Betrayal, Rivera backs up Chiniquy's claims by revealing secret information about a post-assassination smear campaign by the Church against Lincoln 
given him by "Jesuit historians when he was under oath" (59). ${ }^{59}$ Rivera in fact wrote the forward to one edition (1981) of Chick's abridgement of Fifty Years. And Chick uses Chiniquy to support Rivera, with quotations and citations from Fifty Years or The Priest, The Woman, and The Confessional footnoted in five of the six books that make up the Alberto series ${ }^{60}$ Furthermore, Chick uses both to sell the other, with the back covers of The Big Betrayal and each comic in the Alberto series advertising the works of both Chiniquy and Rivera. The Alberto series also advertises Chiniquy books published by Chick in its footnotes: a note in Double Cross states, "For your in-depth study of Roman Catholicism, Chick Publications has the great classic, 'Fifty Years in the Church of Rome' by Chiniquy (2). ${ }^{61}$ On Chick's website, though available for purchase separately, the Alberto series and the Chiniquy comic are literally bundled together for sale as the "Alberto Series Comic Pack."

By using one to support the other, Chick creates an ethos of association between Rivera and Chiniquy. Indeed, this textual camaraderie between these two ex-priests suggests the importance of the ethos of association for renegade rhetoric. The witness of one helps support the testimony of the other, which is needed in light of the degree of suspension of disbelief required to assent to meta conspiracy theory claims. And yet it points to the challenge of association, for the same dynamic that supports one ex-priest, supports another. If you distrust one, it's easier to distrust another. For better or worse, you are tied to the one with whom you associate. And in the case of Rivera, there are genuine questions about whether his story is true and thus whether he can be trusted: is he a genuine renegade, a true ex-priest? In 1981 the leading evangelical magazine Christianity Magazine exposed significant problems in the Rivera narrative, publishing 
Gary Metz's “Jack Chick's Anti-Catholic Alberto Comic Book Is Exposed as a Fraud”: “This reporter's investigation shows that not only was Rivera not a Jesuit priest, but also that he had two children during the time he claimed to be living a celibate life as a Jesuit" (50). But rather than retreat from his support of Rivera, Chick published and expanded the Alberto comic series, all the time using Chiniquy (among others) to support Rivera's charges. To this day, Chick's website features (1988) Is Alberto for Real? (published by Chick Publications), a defense of the Rivera story by Sidney Hunter, which refers readers to a variety of anti-Catholic sources including two expriests and an ex-nun as well as Charles Chiniquy $(19,31-32) \cdot{ }^{63}$ In one place, Hunter points to the benefits of multiple witnesses: "Rivera is not alone in his view, but rather is just one among an endless line of respected authors, including modern writers, who are saying much the same thing" (18). Although Rivera and Chiniquy are renegades, they are not mavericks - they are part of a movement, a community. And one with whom they associate — and appropriate—is the assassinated Lincoln. Hunter points readers to Chiniquy's Lincoln dialogue in Fifty Years stating, "Abraham Lincoln agrees with Alberto Rivera" (31).

\section{Contemporary Use of the Chiniquy Narrative-A Literary Sponsor of Apocalypse}

If the A.P.A. Magazine mixed the spiritual and the secular, with its attacks on the Catholic Church as both bad for the eternal soul and the life of the nation, The Big Betrayal and Alberto series comic books focus on anti-Catholicism; however, The Big Betrayal is not without some lingering residue of nineteenth-century nativism. Chiniquy's 1878 letter, twice printed in the A.P.A. Magazine, reappears (much 
abbreviated) in Chick's comic, along with a footnoted estimate from Rivera that " $80 \%$ of our congressmen were pro-Roman Catholic" (49). The focus of Chick's anxieties, though, is not the Irish immigrant, who has long since assimilated into American culture; unlike nativists, Chick's worries are not about immigration. His concerns are more universal—and eternal. If those nineteenth-century nativists who used Chiniquy warned of Roman control of the American republic via migrants to our shores, twentyfirst-century anti-Catholics like Chick who use Chiniquy and Rivera warn of an even greater disaster, one on a truly global and final scale: the end of the world. ${ }^{64}$ Chiniquy has come to be a supporting witness in the case for an apocalypse, predicted in the New Testament's Revelation, by means of the Catholic Church.

While apocalyptic and conspiracy rhetoric are not identical (Crowley 172-73; O'Leary 6). conspiracy theory does drive Chick's anti-Catholic message of an end-time apocalypse: "For Chick and his supporters, Catholicism — and the Jesuits in particularplay the same role in American religious and political culture that the Illuminati or the 'shadow government' do elsewhere in the broader culture of conspiracy theory" (Bivins 57). When challenged concerning whether "Rivera's 'Conspiracy Theory' is extreme and paranoid," Hunter (in a work published by Chick with a foreword written by Chick) responds by explaining that there are two ways understand world history: the accidental and the conspiratorial theory. In the accidental theory, "All events, such as those world depressions, revolutions, wars, and political plots are the results of pure chance" (16). This view he dismisses "as ridiculous as belief in evolution!" In contrast, in the conspiratorial view, "World events ... take place because some influential people want them to happen and make them happen." "To us," he concludes, "the conspiratorial 
theory makes far more sense." He goes on to remind "students of the Bible" that "the accidental theory contradicts the entire theme of the Bible, not to mention large portions of Bible prophecy" (16-17). Although as Goldberg points out, evangelical Christianity is "not synonymous with conspiracism" there has been an "overlap" (84). In post-World War II America, evangelists " $[\mathrm{u}]$ sing diverse means . . . aggressively beseeched the unforgiven to repent before judgment day," with "Christian conspiracists set[ting] the pace and tone for this new great awakening" (67). Goldberg concludes, "In the quest for souls, evangelists . . . magnified of the Antichrist in the drama of salvation. Belief in conspiracy has become as essential to repentance as faith in Jesus" (104).

For Jack Chick, the Catholic Church is not an adversary of Satan but his servant that will help bring about Armageddon. His comic book adaptation of the Bible concludes with the end of the world featuring a "super-church" made up of "all denominations pull[ed] together under the Roman Catholic institution": this is the "Great Whore of the book of Revelation," whose "religious leader will be an imitator of Christ and in reality the Anti-Christ" (King of Kings! 63). ${ }^{65}$ Some Protestants have long seen the Catholic Church as a fulfillment of dire prophecies in the Bible's last book. Wills writes of the "long Protestant tradition identifying Antichrist with the pope" (372). ${ }^{66}$ But as opposed to many American Protestants prior to the late nineteenththrough the twenty-first centuries, Chick situates the Church within a premillennial understanding of the end of the world: "Chick's tracts are substantially influenced by his belief in premillennial dispensationalism" (Dittmer [2007] 283). ${ }^{67}$ Premillennialism, a now commonly held view among evangelicals and fundamentalists, is the doctrine 
that Jesus will return before (pre) the ushering in of his thousand-year reign (millennium) as described in the book of Revelation. ${ }^{68}$ Though popular today, this view has not always been so among conservative American Protestants; in fact, up through the nineteenth century, the more dominant view was postmillennialism, which is "the belief that the Second Coming will take place after [post] the millennium of blissful peace and prosperity for the church, which will be ushered in by the divinely aided efforts of the church" (Pointer [1999]). ${ }^{69}$ The two have a significantly different view of the future before the end, with premillennial thought seeing the world getting worse and worse while postmillennial thought seeing the world (at least from a Christian point-ofview) getting better and better: Wills speaks of its "optimistic nature of history" (356). ${ }^{70}$ And the two views of the end might lead to different political actions in the present (see Stephen D. O'Leary's Arguing the Apocalypse: A Theory of Millennial Rhetoric [1994] 12). ${ }^{71}$ As Chiniquy's message proved useful to the political cause of nativism, so, too, it proves useful to the religious cause of premillennialism. Chiniquy's renegade rhetoric is adaptable to more than one cause. Chiniquy is used to support Chick-and Rivera'spremillennial message. ${ }^{72}$ He provides another witness against Catholicism. For example, in fifth comic in the Alberto series, the Four Horseman, Chiniquy's Fifty Years is footnoted as a source to support Rivera's argument that the pope is the antiChrist (25). ${ }^{73}$ And Rivera's foreword to Fifty Years opens by warning readers that the Church is the same today as it was in Chiniquy's day, with "the false priests of Rome" distorting the Bible "under the leadership of the spirit of anti-christ."

Chiniquy would no doubt approve of seeing the Catholic Church as an antichrist figure. He did, after all, call the Church "the great harlot of the Bible" (569), and ends 
Fifty Years with a quotation from Revelation about "the great whore" (831). However, premillennialism is not a major or even minor theme in Fifty Years. ${ }^{74}$ And yet, Fifty Years lends itself to this particular doctrinal movement. In so doing, it enacts a dynamic similar to Chiniquy's relationship with the A.P.A. Magazine: whether he was or was not a nativist, his message had themes that resonated with nativism. So, too, with Chick's premillennial apocalypticism: regardless of whether Chiniquy believed in a rapture, his message is easy to align with and support one that does. This demonstrates, again, the powerful appeal of renegade rhetoric; it also suggests its usefulness for more than one type of public rhetoric. Chiniquy serves the apocalyptic cause because he portrays the Church as a false faith, a tool of Satan, a conspiracy against the world — as the voice of his conscience, through which God is speaking, tells him while still a Catholic, "your church is the devil's church" (Fifty Years 608). And associating the Church with Satan, making the Vatican the devil's own, is perhaps the ultimate ethos of character assassination.

In so using Chiniquy, Chick acts as a sponsor of religious, or perhaps antireligious, literacy. Deborah Brandt (2001) describes literacy sponsors broadly as "any agents, local or distant, concrete or abstract, who enable, support, teach, and model, as well as recruit, regulate, suppress, or withhold literacy—and gain advantage by it in some way" (19). Sponsors for Brandt include a wide variety of agents, including "religious leaders," and she cites Baptist and Methodist ministries through whose sponsorship "African Americans in slavery taught each other to understand the Bible in subversive liberatory ways" $(19,20) .{ }^{75}$ Jacobs adds that "[w] hen churches use comics to 
think about the Bible ... [they] are being used as a way to sponsor another kind of multimodal literacy" (18). ${ }^{76}$ On the cover of each comic in the Alberto series is the same note: "Recommended reading for adults and teens." Indeed, Chick's combination of visual and verbal positively affects his literary distribution: in "cartoon tracts" such as Chick's, according to Dittmer, "The union of text and image inherent to the medium is amenable to cheap production and maximum literacy by people of different languages and literary abilities" (299). In acting as literacy sponsor, Chick stands to gain financial advantage. ${ }^{77}$ However, if viewed as a sincere believer of the views contained within his comics, Chick seeks to gain something even more important: souls. Bivins writes: "The final page of every Chick tract contains a brief set of instructions on how to be saved. As in the conversion scenes frequently rendered in the tracts, this final page is somewhat formulaic. After pages spent energetically, hyperbolically documenting evil, the reader's journey ends with the enumeration of a series of steps - the kind of formula Americans seem to love - to be taken before and after salvation" (86). It is here where Chick's readers, having been schooled in the literacy of anti-Catholicism and apocalypticism can find not only salvation but also agency. ${ }^{78}$ As opposed to some types of conspiracy theories, for which there is never a promise of justice or even closure, for Christian believers in a conspiracy-driven apocalypse, there is always hope. The devil and his harlot may be conspired against them, but believers have charge of their eternal destiny. As the back cover of The Big Betrayal states, "The decision you make determines where you will spend eternity_Heaven or Hell." 


\section{From Page to Picture to Pixel: A Nineteenth-Century Renegade and the Twenty- First Century World Wide Web}

Chiniquy and his Lincoln conspiracy theory remain in print today. In addition to comics, Chick publishes an abbreviated edition of Chiniquy's autobiography, putting "Church" in scare quotes lest anyone believe that the Catholic Church is any real sense a Christian church: "Fifty Years in the 'Church' of Rome (1985). The back cover promises readers both the ethos of association and assassination: they will "[1] earn how ... a young lawyer named Abraham Lincoln saved his [Chiniquy's] reputation.

Chiniquy proves that it was the Jesuits who later killed Lincoln, and explains why.",79 But Chiniquy's presence on the printed page is not limited to Chick Publications. There are privately printed or self-published books concerning Chiniquy, including defenses of Chiniquy (and attacks on the Catholic Church) such as Eric J. Phelps's Vatican Assassins: "Wounded In the House of My Friends": The Diabolical History of the Society of Jesus Including: Its Second Thirty Years' War, 1914-1945, Its Cold War, 1945-1990, And Its Assassination of America's First Roman Catholic President, Knight of Columbus John Fitzgerald Kennedy (1963) (2001). C. T. Wilcox’s The Transformation of the Republic: The Origins of the Religious Hi-Jacking of the American Government and the Truth Behind the Assassination of Abraham Lincoln (2005) and Paul Serup's Who Killed Abraham Lincoln? An Investigation of North America's Most Famous Ex-Priest's Assertion That the Roman Catholic Church Was Behind the Assassination of America's Greatest President (2009). ${ }^{80}$ In 2008, former news anchor for the Washington D.C. ABC affiliate and current anchor for Aljazeera America Del Waters published The Race, a contemporary political thriller featuring 
Chiniquy and the Lincoln assassination. ${ }^{81}$ In addition to self-published works, as recently as 1999, a major book house published an anti-Catholic work that uses Chiniquy to support a Catholic plot against Lincoln: HarperCollins published Grammynominated songwriter F. Tupper Saussy's Rulers of Evil: Useful Knowledge About Governing Bodies. The scathing review in Publisher's Weekly ends by calling Saussy's book "an anti-Catholic version of The Protocols of the Elders of Zion." 82

Chiniquy and his appropriated Lincoln also appear on the Internet. They have entered "the age of digital democracy" (Olmsted 223), with David P. Weimann calling the relationship between the Web and conspiracy theories "a match made in heaven" (347). ${ }^{83}$ While the egalitarian nature of the Internet has no doubt at times been exaggerated, it has opened opportunities for those not able to get their messages distributed through traditional gatekeepers, such as editors, publishers, and journalists. ${ }^{84}$ Indeed, the Internet has changed the ease of access for conspiratorial and other marginalized discourses: both the A.P.A. Magazine and Chick Publications illustrate the challenges facing pre-Internet print-bound publishers. Distribution was a constant problem for the A.P.A. Magazine (which only lasted for two years). Price castigated association's membership for not properly supporting not only his magazine but the "patriotic" press in general: "any member of the order who does not take and pay for at least one [paper] regularly is no more of an American at heart than the Catholic saloonkeeper on the corner" ("Small Talk," September 1895, 403). ${ }^{85}$ The controversial nature of the magazine, of course, brought its own challenges. Price claimed the "chiefest trouble the magazine has had to contend with is that the news-dealers of the country have usually declined to give it counter or window room, claiming to fear they would 
lose their Catholic customers" ("Where to Buy this Magazine," January 1896, 834). As it turned out, that would not be the magazine's chief trouble; instead, it would be the jailing of the editor in San Quentin state prison. His offense? Mailing "obscene" materials. ${ }^{86}$ Price would temporarily change the masthead for the magazine to list him as "W. E. Price (Convict), Editor and Publisher" (2.6 May 1896). ${ }^{87}$ In the April 1897 issue, the magazine published a one-page defense and valorization of Price: he had done nothing wrong but had been the victim of Catholic persecution ("As To W. E. Price" 1930). Regardless, Price was imprisoned and the magazine came to an end. ${ }^{88}$ Chick, too, has had problems with distribution. In the controversy that ensued as a result of the Christianity Today expose of Rivera, the Christian Booksellers Association (CBA) distanced itself from him and his work, leading Chick to eventually resign his membership (Massa 116-19). ${ }^{89}$

But the distribution problems faced in the age of print are eased in the digital age. I am not suggesting that the Web takes away any and all problems in delivering messages; there is, for instance, unequal access to the Net. But the circulation problems faced by print-based publishers like Price in the 1890s and Chick in the 1980s are reduced by Web. Indeed, anti-Catholic has a presence on the World Wide Web-with Chiniquy only a mouse click away. ${ }^{90}$

On Facebook, one can "like" Fifty Years In the Church of Rome ${ }^{91}$ and Charles Chiniquy, ${ }^{92}$ with an interdenominational ministry posting a note using a Lincoln quote from Chiniquy. ${ }^{93}$ Chiniquy has a Wikipedia page, with a link to The Big Betrayal on Chick's website. ${ }^{94}$ The text for Fifty Years shows up on several sites, including Google Books $^{95}$; on Amazon.com, Chick's abridgement has forty reviews with a $4.2 / 5$ average 
rating. ${ }^{96}$ On his website, the noted Irish anti-Catholic preacher and politician Ian Paisley has an essay on the "cult" of Mary quoting Fifty Years,${ }^{97}$ while another author on the same website uses Chiniquy and his Lincoln warnings. ${ }^{98}$ On YouTube, one can listen to Fifty Years being read ${ }^{99}$ or watch videos laying out the case for a Catholic assassination of Lincoln. ${ }^{100}$ On a forum on national radio host and conspiracy theorist Alex Jones's Prison Planet, one user posts an extended citation of Lincoln from Fifty Years, which stirs the memory of another participant:

I used to have a copy of the book by Charles Chiniquy that you refer to years ago when I was a teen. I had forgotten about it until now. A very interesting book that enlightened me about the Roman Catholic Church. I discovered this book through a reference made in some Christian tracts and comic magazines which I can't recall the name of at the moment. I wish I still had it now. I would like to read it again in light of everything I have learned since then. (steelnvelvet) $^{101}$

Perhaps what this response illustrates is that while Chiniquy has found a place on the Net, he remains attached to the world of print (or at least the e-book).

\section{An Ethos for the Centuries}

A 1952 advertisement for the John Hancock Mutual Life Insurance Company, featuring an illustration of a seated Lincoln, asked, "Why do we love this man, dead long before our time, yet dear to us as a father?" 102 The ad proceeds to describe Lincoln's life, highlighting various qualities-“He was strong and kind. He'd never try to hurt you, or cheat you, or fool you." And then it concludes, "Abe Lincoln always did 
what most people would have done, said what most people wanted said, thought what most people thought when they stopped to think about it. He was everybody, grown a little taller - the warm and living proof of our American faith that greatness comes out of everywhere when it is free to come." The ad captures the devotion that has come to the great emancipator-he is a part of "our American faith." And it suggests the ability of Lincoln via faith - via memory - to become who we wish to be. For those in whom the memory of Lincoln lives, he is an ideal-he is everybody, only a little taller. But in the history of Lincoln's memory, those who remembered him differed over what it is we know should be done, should be said, and needs to be thought. Lincoln has become everybody, open to anybody's memory and faith, even those who view another faith as a foreign devil's.

\section{Conclusion}

In Toward a Civil Discourse, Crowley locates conspiracy claims in the periphery: "In America prior to the Cold War conspiracy narratives circulated primarily among members of cults and subscribers to relatively unpopular ideologies such as nativism and fascism" (174). Crowley is not alone in marginalizing this type of rhetoric: "Pundits tend to write off political paranoia as a feature of the fringe, a disorder that occasionally flares up until the sober center can put out the flames" (Walker 8). This dissertation, however, argues against this move to trivialize the impact and import of conspiracy rhetoric in American discourse. Through an examination of anti-Catholic rhetoric, which is laden with conspiracy charges, this dissertation joins with Hofstadter and others in demonstrating that since the colonial and revolutionary age Americans 
have held and been motivated to act politically by conspiracy-laden rhetoric. (The 1856 national election, for instance, saw the nativist and anti-Catholic American Party nominate former president Millard Fillmore, who would go on to carry over $20 \%$ of the vote.) Rather than being believed, as Crowley alleges, primarily by "subscribers to unpopular ideologies"—which does not accurately characterize nativism—conspiracy theories have been "a potent force across the political spectrum ... in the establishment as well as at the extremes" (Walker). "They are," Walker writes, "at the country's core." Conspiracy rhetoric is not located in the margins of American discourse: charges of a nefarious plot, the covert scheme, the evil cabal are a default in American argument. Sooner or later-and in the age of the Internet, it is perhaps more often sooner than later-someone will claim (and frequently many will believe) that an event or policy is the result of conspiracy. As Walker states, "In America, it is always a paranoid time" (8).

As in all rhetorical situations, there are a variety of factors involved in any attempt at persuasion, which is certainly true in conspiracy claims. This dissertation has contended for increased attention to the role ethos plays in conspiracy rhetoric. I have argued that ethos construction plays a much more significant role than typically considered, especially in cases involving renegade rhetoric. Hofstadter described the importance played by "the figure of the renegade from the enemy cause" - the exMormon, ex-Mason, ex-nun, or ex-Communist-in American conspiracy argument; Chiniquy's Lincoln conspiracy theory has been a means of testing Hofstadter's thesis. For whether one believed in Chiniquy's tale about the dead president depended on whether one believed in Chiniquy the ex-priest. Chiniquy's text and its use by the 
historically significant anti-Catholic and nativist movements has thus proven an excellent site for analyzing the role of ethos in how renegades used conspiracy argument to support claims not easily established or refuted. Fifty Years has proven itself a rich text for rhetorical analysis, helping extend our knowledge of how ethos is constructed in persuading people to accept extreme or, to borrow Hofstadter's problematic term, "paranoid" claims. Additionally, it has provided valuable heuristics through which to examine other conspiracy claims. But these tropes and heuristics need not be limited to conspiracy rhetoric. Further research should be done, for instance, on the ethos of association and the ethos appropriation in other types of public and political rhetoric.

Over three centuries, Chiniquy's text demonstrated a remarkable longevity and popularity among nativists and anti-Catholics. Part of this appeal, I argue, stems from his alleged relationship with one of the most vaunted characters of the American cultural pantheon. Of the ex-priests (alleged and actual) of the nineteenth century, it was Chiniquy who claimed that he was the friend of the sixteenth president, and it was Chiniquy who claimed that from Lincoln's lips came forth allegations of a Catholicdominated confederacy aiming to end the life of the union and its great emancipator. Chiniquy's endurance and esteem, I would argue, is at least partially based on his ethos construction. If this assertion is correct, it would confirm the importance of ethos as described by Aristotle, who argued for its importance to persuasion in general but especially "in cases where there is not exact knowledge but room for doubt" $(38 ; 1.2 .4)$. In alleging conspiracy, in which undisputable evidences are challenging to provide, thus leaving room for doubt, the persuasive appeal of a renegade largely rests on the rhetor's 
ethos. In Chiniquy's case, if people believed this ex-priest's charges of Jesuit plots, they believed because they believed in him, his personal story, his character, his narrative of defection from darkness to light, via the construction of his ethos. But his ethos was one intertwined with another's. Through association and appropriation his message rested not only on his life and word but also on that of another: Abraham Lincoln's. Chiniquy's text and its longstanding use by a variety of organizations thus expand our understanding of the construction of ethos in persuasion and the use of memory as an ethos transaction.

According to an October 2, 2013 survey by Public Policy Polling, by varying degrees, a significant number of Americans believe in some type of conspiracy theory: $17 \%$ believe that "a group of world bankers is slowly eliminating paper currency until most banking is done electronically, and then will cut the power grid so that most citizens will not have access to any money and will be forced into worldwide slavery"; $19 \%$ "think there is a secret society such as Skull and Bones that produces most of America's political or financial leaders to serve the interests of the wealthy elite"; $25 \%$ believe that President Obama is "secretly trying to figure out a way to stay in office beyond 2017"; and 36\% believe the "Obama administration is secretly trying to take everyone's guns away ("Republicans More Likely To Subscribe to Government Conspiracy Theories” 2, 3). ${ }^{103}$ Reminiscent of nineteenth-century anti-Catholic anxieties over Jesuits potentially inflicting papal rule over the United States, $25 \%$ of those surveyed think that "Muslims are covertly implementing Sharia Law in American court systems" (3). And though 70\% answered "no" to whether they "think the U.S. 
government engages in so-called 'false flag' operations, meaning that the government sometimes plans and executes mass shootings or terrorist events, and then makes it look like those activities were carried out by others," $13 \%$ said "yes," while $17 \%$ stated, "not sure" (2). In other words, up to $30 \%$ of Americans might look at the recent Boston Marathon bombing or the Newton, Connecticut shootings as being the work of the American government. ${ }^{104}$ As one of Don DeLillo's characters states, "This is the age of conspiracy. ... This is the age of connections, links, secret relationships" (Running Dog 111). But as this dissertation has shown, in American socio-political-religious discourse, it is always the age of conspiracy.

\footnotetext{
${ }^{1}$ Maury is not alone in his view of Chiniquy. Shortly after his death, The Literary Digest (February 25, 1899) eulogizes him as the one who "has been for the last four decades the foremost figure in the Protestant propaganda with regard to Roman Catholics" ("Two Accounts of Father Chiniquy" 227). Michael Williams (1932) calls Fifty Years a "certain masterpiece of anti-Catholic literature" (92), one that "gave promise of eclipsing the books of Rebecca Reed and Maria Monk in arousing agitation in the breasts of those alive to the menace of popery" (92-93). Les Wallace (1990) states that Fifty Years "provided another major fund of anti-Catholicism from which the climate of opinion [in the latter nineteenth century] drew" (30). Dennis Castillo (2003) describes Fifty Years as a "very popular anti-Catholic work from the nineteenth century that remains in print today" (370). Mark A. Noll and Carolyn Nystrom (2005) speak of Fifty Years as one of the "classic anti-Catholic works" (40). Kinzer calls Fifty Years "probably the first-ranking, certainly no less than second, of all anti-Catholic best sellers," arguing that the "growing" anti-Catholicism of the 1880s "fed on" Chiniquy's autobiography, with one of the alleged Lincoln quotations being "used constantly throughout the ensuing [A.P.A.] crusade" $(31,32)$.

${ }^{2}$ Knobel calls the A.P.A. "[t] he most notable nativist organization of the period" from 1885-1910 (193). Higham states, "It absorbed many of the other nativist societies which had sprouted in the eighties and dominated the gaudiest wave of religious nativism in fifty years" (80). Bennett compares the A.P.A. to other 1880s nativist organizations: "most of them would make little progress in attracting a mass membership on their own. In fact, only one nativist fraternity became - if briefly - a truly mass movement in the 1890s, a possible heir to the Know Nothings of the past. That was the American Protective Association" (171). Williams (1932) describes the A.P.A.'s initials as having "been branded on the popular consciousness almost as deeply as the later avatar of religious prejudice, the K.K.K." (95). Les Wallace (1990) calls the A.P.A. "the leader in the rhetorical crusade for anti-Catholicism in post-Civil War America" (2). He argues
} 
that "in terms of membership, political influence, and organizational life span," the Association "achieve[d] an impressive record of success."

${ }^{3}$ It is difficult to prove the influence of any socio-political movement. The A.P.A. as an organization did not have an extensive period of political power, peaking by the early to mid 1890s. Williams describes three factors 1892-1894 leading to its rise: "Loosening of party ties and political unrest; . . Industrial panic and depression; . . . Special Catholic celebrations throughout the country, and the visit to the United States of Monsignor Satolli, the papal delegate" (98). Though the A.P.A. Magazine had a national reach (see its listing of places where it could be bought), Higham describes it as a "product of the Middle West" (86). (William O'Connell Bradley, Kentucky's first Republican governor [1895-1899] was supported by the A.P.A. [Kinzer 199].) Nordstrom writes, "The APA coalesced with other nativist and nationalistic organizations in the early 1890 s and by 1893 , the APA was a full-fledged national movement. APA members proved highly influential in state and local elections in 1894, although concerns of whether to support Republican candidates or run their own independent presidential campaign split the movement in 1896, after which the APA gradually faded out of existence" (110). The APA had not proven itself necessary for Republicans to win in 1896, which also diminished its political cachet. See also Bennett 171-79, Higham 80-87, and Kinzer 247-49. For a contemporary account of the A.P.A. in Ohio, see Congregational minister and Social Gospel proponent Washington Gladden's 1909 Recollections. Gladden, an opponent of the A.P.A. claims that the Ohio legislature "was under its control" (362); he also claims to have lost being appointed president of Ohio State University because of his opposition (414-15). For more on the A.P.A. in Ohio, see Kinzer 67-71, 84. Gladden's Recollections is available here: https://archive.org/details/washingtonrecoll00gladuoft. Gladden also wrote about the A.P.A. for The Century (47.5 [March 1894] pp. 789-96), available here: http://digital.library.cornell.edu/cgi/t/text/pageviewer$\mathrm{idx} ? \mathrm{c}=$ cent $; \mathrm{cc}=$ cent;rgn $=$ full $\% 20$ text $; \mathrm{idno}=$ cent0047-5; $\mathrm{didno}=$ cent 0047 $5 ;$ view $=$ image;seq $=799 ;$, ode $=$ cent0047-5\%253A27;page $=$ root; size $=100$

${ }^{4}$ It is difficult to determine the exact membership of the A.P.A., which is not surprising given that it was a male-only secret society (there was a W.A.P.A for women). According to Kinzer, "There are, apparently, no organizational records - no minutes book, no membership lists, not even a constitution - to provide the student with basic materials" (v). In a March 1, 1899 letter to Humphrey J. Desmond, the founder of the A.P.A. Henry Bowers writes that he cannot give the approximate rate of growth during the early years (1889-1891) of the organization "because the records containing the facts were destroyed by fire" (qtd. in Desmond [1912] 16). Kinzer states, "Any estimate of the membership of the A.P.A. must take into account the fact that the order was at one and at the same time a secret society with its own distinct membership list, and a federation for political purposes of self-styled 'patriotic societies.' The total membership of the federation was probably somewhere near the two and one-half million figure [which the A.P.A. claimed for itself]; the actual membership of the A.P.A., that is the distinct lodge, was perhaps one hundred thousand" (177). Higham and Bennett both proffer higher numbers: Bennett suggests "more than one-half million members" (173), and Higham offers, "it may have enrolled a cumulative total of half a 
million members" (81). (The population of the United States in 1890 was roughly 63,000,000.)

${ }^{5}$ Membership in a Catholic church meant obedience to a foreign potentate, the Pope in Italy, thus making the Catholic faith inherently at odds with American democracy. The full statement of principles is also available in Kinzer 45-46. Kinzer also includes this A.P.A. oath, taken as part of the initiation into a council: "I hereby denounce Roman Catholicism. I hereby denounce the Pope, sitting at Rome or elsewhere [there was a fear that the Pope would eventually move to the United States to take up residence]. I denounce his priests and emissaries, and the diabolical work of the Roman Catholic church, and hereby pledge myself to the cause of Protestantism to the end that there may be no interference with the discharge of the duties of citizenship, and I solemnly bind myself to protect at all times, and with all the means in my power, the good name of the order and its members, so help me God. Amen" (49). Interestingly, the A.P.A. Magazine printed an oath (different from above), with no comment from the editor in a section of the magazine devoted to selections from the Catholic press: "Oath of the A.P.A. According to the 'Santa Clara,' San Jose, Cal." (1.1 [June 1895] p. 74). ${ }^{6}$ Anti-Catholics complained of biased coverage in the mainstream press. Wallace writes, "The outside press sometimes reported A.P.A. lectures, but the reports were generally buried in back sections and accompanied with equal of double space rebuttal. The New York Times is a representative example. During the years 1893-1896 the Times averaged about fifteen stories per year concerning A.P.A. activity and propaganda. The reports usually reflected an obvious anti-A.P.A. bias and frequently allowed ample Catholic rebuttal space" (105-106). For an example of a newspaper regretting advertising a Chiniquy lecture see the Washington D.C. Evening Star (“"Friend' writes to inquire." February 19, 1890, p. 4, col. 1). Chiniquy was holding a series of lectures in Washington D.C., and the Star advertised on the front page a lecture of Chiniquy's on claims about Catholic participation in Lincoln's death (February 12, 1890, col. 2). According to the February $19^{\text {th }}$ issue, the Star claimed that it was "[t]hrough an oversight at the advertising counter" by which Chiniquy was able to advertise, "Last night the church was full to hear the illustrious orator on the murder of Abraham Lincoln. He charged it upon the Jesuits and gave overwhelming proofs." The paper explains that this was an oversight and that their policy, applied to all, is to not print "offensive and libelous matter" of this kind. Available here: http://chroniclingamerica.loc.gov/lccn/sn83045462/1890-02-19/ed-1/seq-4/

${ }^{7}$ Wallace writes: "The National Council of Patriotic Organizations, of which the A.P.A. was a member as of 1891, gave early consideration to methods - 'strategies' - for arousing public opinion against the Catholic menace. The heads of all 'Patriotic' organizations received a circular (circa 1892) entitled 'Plans for Aggressive Work.' The letter suggested that each organization should inform the public of its work by publishing 'millions of copies' of documents. The leaders were further admonished: 'Set the secret organizations at work as committees of distribution to district their towns and cities and place these documents and papers at every door, doing it at night so that no one can tell where they came from and no one can tell where to strike back or whom to boycott"” (101). Wallace's source is Allen W. Burns's "The A.P.A. and the AntiCatholic Crusade: 1885-1898” (unpublished M.A. thesis, Columbia University, 1947, 
page 25). The content of these handbills varied: "some were articles attacking Catholics while others were simply lists of candidates for office with religious affiliations clearly identified. In the former, the diatribe might be a testimony of an alleged ex-priest revealing the danger of the Catholic Church" (101-102).

${ }^{8}$ I was able to examine twenty issues of the A.P.A. Magazine (3 volumes, with one issue [3.8] missing, dated June 1895-June 1897); these appear to be the magazine's run, with a different editor taking over shortly before its end. A great deal of the so-called patriotic press no longer exists (or there is no record of it). Kinzer describes the examples which he used for his book as "the remnants of the self-styled "patriotic press"": "Of somewhat near one hundred of these periodicals for which titles and publication were found, seventeen were used, most of them partial rather than complete" (vi). Nordstrom, examining anti-Catholicism during a slightly later period (1910-1918), also describes the loss of many publications: "available copies of antiCatholic newspapers . . . fluctuate widely_ranging from several hundred copies . . . to a few dozen issues ... [to] only scattered issues. ... Over a dozen Progressive-Era antiCatholic papers are completely lost to the historical record" (11-12). The A.P.A. Magazine then serves as a relatively rare resource for studying this once prominent means of distributing the anti-Catholic and nativist message. (See Kinzer [255ff.] for his use of the magazine's listing of the patriotic press for assembling a list of the newspapers that made up the anti-Catholic press.)

${ }^{9}$ Its name should not be taken to mean that this magazine was the official publication of the A.P.A. To the best of my knowledge, it was an independent magazine published to support the A.P.A. organization and movement.

${ }^{10}$ Renegade rhetoric ("the figure of the renegade from the enemy cause" [Hofstadter 34]) was popular not only on the page but also on the speaker's platform. The A.P.A., according to Wallace, "discovered that the public would flock to hear the so-called 'expriests' and 'ex-nuns' reveal Catholic secrets and describe the horrors of the Church" (111). He does argue, though, that their "usefulness . . proved short-lived" due to many being "exposed as charlatans" or having "questionable backgrounds as drunkards or fallen women" (114). He adds that they also drew forth the most negative responses by those opposed to the Association, something it "preferred to shy away from," given that "it could ill afford the criticism" (115). If the ex-priests and ex-nuns did carry liability, in the history of anti-Catholicism they also displayed great longevity in terms of rhetorical appeal, with renegade rhetoric remaining prominent throughout the twentiethand into the twenty-first centuries.

${ }^{11}$ See inside covers for a full listing of books.

${ }^{12}$ Not everyone who claimed to be was in fact an ex-priest: "There were also a number of 'ex-priests' who were not really such, but who had in most cases attended some Catholic institution for a time. Among these were Ruthven, Walsh, Koehler, and Bluett" (Williams 105).

${ }^{13}$ Kinzer suggests two ways the Iowa resolution could be understood: "One was that the former priests encouraged the order to violate its stated principles, the other was he was a 'leech,' who deprived the sponsoring council of its rightful revenues" (113). George T. Wallace (1895), secretary of a Memphis, Tennessee council, claims that the association's intention was to have the ex-priests speak only to the political problems 
with the Catholic Church in their capacity as A.P.A. lecturers; as individuals, they could speak to the religious wrongs of the Church. Rather than they're having been a falling out, "We of the order know that the A.P.A. is friendly toward the ex-priests" ("A Word for the Ex-Priests" 324). Not everyone, though, saw these resolutions as well intended. Ex-priest Thomas Leyden writes, "such resolutions are premature and uncalled for; and, no doubt, were the result of a narrow, ignorant view of the work, or perhaps were born of a fear that sees evil in everything that cannot be understood" ("Ex-Priests and the A.P.A." 63).

${ }^{14}$ Ex-priest Slattery (1896) gives the following as the wording of the national convention's resolution: "Resolved, That whenever an ex-priest or ex-nun is lecturing, or claims to be lecturing, under the auspices of the A.P.A. that we denounce him and show him up, etc." ("Ex-Priests and the A.P.A." 761).

${ }^{15}$ The A.P.A. Magazine is one of many Gilded Age publications to feature Chiniquy and/or the Lincoln conspiracy theory. Among books available online, see Hugh Montgomery's Plain Talk About the Romanism of Today (Boston: American Citizen Co, 1894: 191); ex-Catholic Thomas Rush's The Roman Catholic Machine Turned Inside Out (Boston: 1891: 96, 118, 119); Burton A. Huntington's The Coming American Civil War: Washington's Words of Warning, Lincoln's Apprehension and the Prophecy of General Grant: The Indications of Coming Conflict, Abundant and Certain Minneapolis: Printed for the author, 1893. Print: 28-29, 31-39, 43-44, 48-52); Oliver E. Murray's The Black Pope; Or the Jesuits' Conspiracy against American Institutions (Chicago: The Patriot Company, 1892: 61, 99-100, 188-191, 256-60), which is a compilation of lectures given by different members of various anti-Catholic/nativist societies, including the A.P.A; John L. Brandt's America or Rome, Christ or the Pope (Toledo: The Loyal Publishing Company: 397-98, 456-60), which includes an introduction by W. J. H. Traynor, supreme president of the A.P.A. Isaac J. Lansing's Romanism and the Republic. A Discussion of the Purposes, Assumptions, Principles and Methods of the Roman Catholic Hierarchy (Boston: Arnold Publishing Company, 1890: see index and p. 272) — note that on pages iv-v, Lansing mentions using Chiniquy's Fifty Years as a source; Justin D. Fulton's Washington in the Lap of Rome (Boston: W. Kellaway, 1888: 115-135); A J. Grover's Romanism, Or, Danger Ahead: The Reason Why a Good Roman Catholic Cannot Be a Good Citizen of This Republic (Chicago: Craig \& Barlow, 1887: 80-81, see also a poem using Chiniquy [126] and an ad for Fifty Years [127]).

${ }^{16}$ The quote is from W. E. Gladstone: "No more cunning plot was ever divulged against the intelligence, the freedom, the happiness and virtue of mankind, than Romanism." According to the article in the A.P.A. Magazine, the Catholic bishop of Los Angeles sent the quotation to Gladstone to confirm or deny its authenticity. Gladstone responded in part, "to the best of my knowledge and belief I never wrote and never could have written at any time of my life the words which you cite. I disapprove highly of them" (922). The author (whom I assume to be the editor, Price) goes on to make a complicated argument that rather than showing Chiniquy - and the magazine - to be wrong, the bishop's correspondence proves him to be a "prince of liars." The author states that he had from memory of Fifty Years written the quotation for the cover, and had got one word wrong: he wrote "divulged" when the original is "devised." However, 
the bishop had sent the quotation from the original and not the magazine; therefore, how the bishop lied when he claimed to be quoting the A.P.A. Magazine. As it turns out Chiniquy was misquoting Gladstone, adding the phrase "than Romanism" to Gladstone's words. See a further complicated defense a few issues later in "A Question of Veracity" (April 1896, 1093-1095). The Gladstone's original statement can be seen here (bottom of page 45): https://archive.org/details/twoletterstoear00gladgoog ${ }^{17}$ Based on the similarity in title, this might have been a reprint of a pamphlet advertised two months prior (September 1895), "Lincoln's Assassination Traced Directly to the Doors of Rome" (404); the anti-Catholic Columbus Record (Columbus, Ohio) published a similar title, perhaps abridged (Columbus Record, 20 July 1893, pp. 2-3, cited in Wallace, p. 54, note 4). Since Chiniquy's allegations became public, there have been a variety of pamphlets focused on his Lincoln conspiracy, several of which are available online (though the dates and publication information is not always available). The Murder of Abraham Lincoln Planned and Executed by Jesuit Priests (Indianapolis: The Ironclad Age, 1893), available here https://archive.org/details/murderofabrahaml00chin;

The Assassination of President Lincoln As Told By Father Chiniquy (unknown date and publisher), available here: https://archive.org/details/assassinationo3611chin; Who Assassinated Abraham Lincoln? (unknown date and publisher; note, the 1880 date listed on the site is incorrect, seeing as the book is based on Chiniquy's 1885 work), available here: https://archive.org/details/whoassassinateda00chin; Abraham Lincoln's Vow Against the Catholic Church (Mitchel Haney Wilcoxin 1909?), available here: https://archive.org/details/abrahamlincolnsv5542wilc; a 1928 version of Wilcoxin's pamphlet (Milan, IL: Rail Splitter's Press, 1928), which includes an illustration of Lincoln on the cover, is also available here:

https://archive.org/details/abrahamlincolnsv00wilc; Assassination of Lincoln by Rev. Charles Chiniquy (Milan, IL: Rail Splitter's Press, 1921?), available here: https://archive.org/details/assassinationofl00chin; there is also a German-language version, Die Ermordung Des Präsidenten Abraham Lincoln Eine That Der Jesuiten ("The Assassination of President Abraham Lincoln, An Act of the Jesuits") (Barmen: D.B. Wiemann, 1890) available here: https://archive.org/details/dieermordungdesp00chin

${ }^{18}$ This is frequently advertised in the A.P.A. Magazine (in addition to Fifty Years and Chiniquy's The Priest, The Woman, and The Confessional); see, for instance, the back materials in 1.4, 1.5, 2.2 , 3.2, 3.4, 3.5, 3.6, 3.7. The January 1896 issue (January) advertises it as containing "The whole story from 'Fifty Years in the Church of Rome,' with much additional information on Romanism. In newspaper form" (836). It sold "[f]ive cents a copy, or six for twenty-five cents, postpaid," from the magazine. ${ }^{19}$ In addition to the earlier cited quotations from the magazine's covers, for other examples of Chiniquy's Lincoln quotes, see Donald Ross's "National Ills and Right Medicine," an 1895 speech (2.2 January 1896: 780); Ray Palmer's "The Clarion Call of our Country," an 1895 speech (2.3 February 1896: 865); Henry Maynard's “The Dangers and Designs of Romanism in the United States," an 1895 speech (3.4 November 1896: 1611). 
${ }^{20}$ Chiniquy was not the only person to have alleged Catholic involvement in Lincoln's murder; others, too, had pointed to the Catholic faith of at least some of the conspirators (with some, wrongly, alleging that all were Catholic). It was Chiniquy, however, who provided that alleged anti-Catholic dialogue with Lincoln.

${ }^{21}$ Anti-Catholics at times positioned the Catholic Irish as having served in King George III's army to help squelch the American Revolution.

${ }^{22}$ Harper's Weekly (October 27, 1894, pp. 1017-18) published a brief article on the A.P.A., including pictures of leading members, such as Fulton. Available here: http://books.google.com/books?id=Y65CAQAAIAAJ\&vq=ex\%2520priest $\% 2520$ georg e \%2520rudolph\&dq=ex\%20priest $\% 20$ george $\% 20$ rudolph\&pg=PA1018\#v=onepage \&q $\& \mathrm{f}=$ false

${ }^{23}$ In a very brief notice of Chiniquy's death, the Pullman Herald (Pullman, Washington) claims, "Father Chiniquy took an active part in the organization of the A.P.A., and is said to be responsible for the story that Catholics connived at the assassination of Lincoln" ("Washington." 28 Jan. 1899: 6). Available here: http://chroniclingamerica.loc.gov/lccn/sn88085488/1899-01-28/ed-1/seq-6/ ${ }^{24}$ Available here: http://chroniclingamerica.loc.gov/lccn/sn84025968/1890-10-31/ed$1 / \mathrm{seq}-4 /$

${ }^{25}$ The possible date for this four-page pamphlet is 1878 , though that is not certain. It is available here: https://openlibrary.org/books/OL19676992M/Mr._Chiniquy_in_California ${ }^{26}$ Excerpts are also included in another A.P.A. Magazine article, E. R. Davis's "Rome Under the Searchlight" (3.1 August 1896), which is a citation from Fifty Years. No doubt there are differences between each instantiation in the magazine, pamphlet, and book.

${ }^{27}$ The Chick Publications website claims that Chick has "written and published hundreds of illustrated gospel tracts in close to one hundred different languages," with "[h] undreds of millions of copies hav[ing] been read world-wide" ("Biography of Jack Chick"). One tract, "This Was Your Life!" (1972), has been their bestseller, having "sold over 100 million copies in almost 100 languages" (David Lynn Bell [2005] 10). Massa argues, "Chick's work reaches more readers than mainstream religious publications" (119). Allowing for the possibility that Chick has inflated the number of booklets, Massa points out that "millions of Americans can nonetheless recall coming across at least one" Chick pamphlet.

Ito's article available here:

http://books.google.com/books?id=v10EAAAAMBAJ\&pg=PA56\&dq=\%22Chick + tract $\% 22 \& \mathrm{hl}=$ en\&ei=sja9Tb3cG4yCvgOf8IG4BQ\&sa=X\&oi=book result\&ct=result\&resn um $=7 \&$ ved $=0$ CFEQ6AEwBg\# $\mathrm{v}=$ onepage $\& \mathrm{q}=\% 22 \mathrm{Chick} \% 20$ tract $\% 22 \& \mathrm{f}=$ false

Chick's biography available here: $\mathrm{http}$ //www.chick.com/information/authors/chick.asp

${ }^{28}$ For a listing, including many that are available to be read online, see Chick's website: http://www.chick.com/catalog/tractlist.asp. The Southern Poverty Law Center "has long listed [Chick Publications] as a hate group due to its militant, vitriolic propaganda against anyone who doesn't adhere to its particular brand of Christianity" (Nelson, Leah. "Pastor Apologizes for Hate-filled Halloween Hand-out" [2011]), available here: 
http://www.splcenter.org/blog/2011/11/02/pastor-apologizes-for-hate-filled-halloweenhand-out/

29 "Of course, Jack Chick does not have a smidgen of Pynchon's talent or vision; nevertheless, he is the Thomas Pynchon of fundamentalists" (Raeburn 4). Raeburn's work on Chick is available for free at his website: http://danielraeburn.com/The Imp, by Daniel Raeburn.html

${ }^{30}$ While Chick takes on a variety of religions and denominations, it is the Catholic Church which receives, by far, the most attention. According to Jason C. Bivins (2008), "of all the 'false' religions to fall under Chick's withering caricatures, Catholicism has endured the most consistently stinging denunciations" (56). Raeburn states, "All of Chick's conspiracies center on the Roman Catholic Church, the 'Whore' and sworn enemy of his one-man cartoon war" (4).

${ }^{31}$ Bivins states, "despite those who would dismiss his work on the basis of its apparent aesthetic value, Chick's tracts have for decades been widely disseminated and highly influential in evangelical cultures, even if his perspective is not wholly normative" (45). Chick, who does not believe in the theory of evolution, has even served as an inspiration for the writing of a pro-evolution comic. See Neda Ulaby's (February 14, 2005) broadcast, "Holy Evolution, Darwin! Comics Take On Science," available here: http://www.npr.org/templates/story/story.php?storyId=4495248

${ }^{32}$ Chick Publications also publishes The Priest, the Woman, and the Confessional and an abridged version of Fifty Years in the Church of Rome. Chiniquy is referred to in his Chick's tracts "Are Roman Catholics Christians?," available here: http://www.chick.com/reading/tracts/0071/0071_01.asp, and "The Awful Truth," available here: http://www.chick.com/reading/tracts/1071/1071 01.asp

${ }^{33}$ On comic books, see Scott McCloud's (1993) Understanding Comics: The Invisible Art and (2000) Reinventing Comics: How Imagination and Technology Are Revolutionizing an Art Form. See also Douglas Wolk's 2007 Reading Comics: How Graphic Novels Work and What They Mean.

${ }^{34}$ Stafford writes, "In spite of their quantity and globalized presence, for many educated people pictures have become synonymous with ignorance, illiteracy, and deceit" (110). She writes the series of essays that make up Good Looking: Essays on the Virtue of Images to give "an alternative view of the pleasures, beauties, consolations, and, above all, intelligence of sight. They [her essays] argue that imaging, ranging from high art to popular illusions, remain the richest, most fascinating modality for configuring and conveying ideas" (3).

${ }^{35}$ See Constance Aerson Clark for a discussion of the role of visuals in the 1920 s Scopes evolution/creation debate: "On a general level, I want to suggest that we cannot understand the complex relationship of science and its larger public if we look at words alone" (1278). "Evolution for John Doe: Pictures, the Public, and the Scopes Trial Debate." The Journal of American History. 87.4 (2001): 1275-1303. Print.

${ }^{36}$ See David Morgan's 2005 The Sacred Gaze: Religious Visual Culture in Theory and Practice (University of California Press).

${ }^{37}$ It should be mentioned that making a neat distinction between the visual and verbal is problematic. The two often work together, and one sees text as much as one sees a picture - the letters of the alphabet are visual script. The lines are blurry. Hill and 
Helmers introduce the essays of Defining Visual Rhetorics remarking, "every contributor rejects the notion that a clear demarcation can be drawn between 'visual' and 'verbal' texts" (20). See also Eva Brumberger's "The Rhetoric of Typography: Effects on Reading Time, Reading Comprehension, and Perceptions of Ethos" (2004), p. 13.

${ }^{38}$ For an example, see the American Tract Society's pamphlets concerning the Catholic Church as discussed in David Morgan's 1999 Protestants \& Pictures: Religion, Visual Culture, and the Age of American Mass Production (93-107).

${ }^{39}$ See just before the title page: http://books.google.com/books?id=1 1ZAAAAMAAJ\&pg=PP6\#v=onepage\&q\&f=false . See also this nineteenth-century edition (exact date unknown) featuring forty engravings: https://archive.org/stream/cihm_38362\#page/n9/mode/2up

${ }^{40}$ Nast's cartoon is available here: http://www.harpweek.com/09Cartoon/BrowseByDateCartoon.asp?Month=May\&Date= 8

${ }^{41}$ For examples of pedagogical approaches to visual rhetoric, including discussions of ethos, see Linda Stallworth Williams's "Strengthening the Ethics and Visual Rhetoric of Sales Letters" (2008) and Mary E. Hocks's (2003) "Understanding Visual Rhetoric in Digital Writing Environments."

42 In "Visual Rhetoric in a Culture of Fear: Impediments to Multimedia Production" (2006), Steve Westbrook writes of visual rhetoric "emerg[ing] as a distinct subject of study within composition" (460).

${ }^{43}$ Kjeldsen cites Quintilian's observation, “many other things have the power of persuasion, such as money, influence, the authority and rank of the speaker, or even some sight unsupported by language, when for instance the place of words is supplied by the memory of some individual's great deeds, by his lamentable appearance or the beauty of his person" (Institutio Oratoria 2.15.6; qtd. in Kjeldsen 133). See also Kevin LaGrandeur's "Digital images and classical persuasion" in Eloquent Images: Word and Image in the Age of New Media. Ed. Mary E. Hocks and Michelle R. Kendrick. Cambridge: MIT Press, 2003. 117-136; and Valerie J. Smith's "Aristotle's Classical Enthymeme and the Visual Argumentation of the Twenty-First Century" in Argumentation \& Advocacy. 43 (2007): 114-123.

${ }^{44}$ See J. Anthony Blair, "The Rhetoric of Visual Arguments" (2004), for a discussion of visuals as arguments.

${ }^{45}$ For a study on the impact of typography and design on ethos, see Eva Brumberger's (2004) "The Rhetoric of Typography: Effects on Reading Time, Reading Comprehension, and Perceptions of Ethos." Ann R. Richards and Carol David make limited references to ethos is "Decorative Color As a Rhetorical Enhancement on the World Wide Web" (2005).

${ }^{46}$ The cover and a brief selection of The Big Betrayal is available on Chick's website: http://www.chick.com/catalog/comics/0251.asp; also see here: http://www.fmhchild.org/TheBigBetrayal.html

${ }^{47}$ On violence in comic books, see the influential critique by psychologist Fredric Wertham, Seduction of the Innocent (New York: Rinehart, 1954). For a recent critique of Wertham, see Carol L. Tilley's "Seducing the Innocent: Fredric Wertham and the 
Falsifications That Helped Condemn Comics" (Information \& Culture: a Journal of History. 47.4 (2012): 383-413).

${ }^{48}$ Contrast this with the text of Fifty Years, which features illustrations of both Chiniquy and Lincoln — but Chiniquy gets the double frontispiece.

${ }^{49}$ Perhaps it's significant to note the popularity of assassination in films about conspiracies. Among many examples, see The Manchurian Candidate (1962), Z (1969), The Conversation (1974), The Parallax View (1974), Three Days of the Condor (1975), All the President's Men (1976), Blow Out (1981), The Pelican Brief (1993), The Ghost Writer (2010).

${ }^{50}$ See also Corey Robin, Fear: The History of a Political Idea (New York: Oxford UP, 2004); Nancy Lusignan Schultz (editor), Fear Itself: Enemies Real and Imagined in American Culture (West Lafayette: Purdue UP, 1999); Beth Innocenti, "A Normative Pragmatic Model of Making Fear Appeals" (Philosophy and Rhetoric 44.3 [2011]: 273290).

${ }^{51}$ Graphic novelist and Academy Award nominated screenplay writer Daniel Clowes describes the effect of reading eighty of Chick's tracts at one time while he was in college: "By the end of the night I was convinced I was going to hell" (Ito 58). He adds, "I had never been so terrified by a comic book."

${ }^{52}$ In shades of Maria Monk, Alberto includes the charge of pregnant nuns killing their babies and burying them on church grounds. One panel depicts a convent on the left and a monastery on the right connected by an underground tunnel with one area designated as "bodies of babies" (12). In The Force, Rivera claims to have seen the corpses of seven infants buried on church property that had been "sacrificed to Mary" (31). Double-Cross, the second in the Alberto series, opens with Rivera rescuing his sister from a convent. When he sees her, he is shocked: "she weighed less than 60 pounds," and her habit was "blood-soaked" as result of "bleeding ulcers on her back caused by the beatings of flagellation" (5).

${ }^{53}$ In gruesome detail, Alberto shows the torture and execution of one alleged victim of the Inquisition, Dona Isabella, who "was placed on the rack. Water was dropped into her mouth drop by drop, forcing a sharp, brittle linen cloth down her throat until it reached her stomach. Then it was ripped out of her, cutting everything from her stomach to her mouth" (17). This explicit prose accompanies a graphic picture. ${ }^{54}$ Rivera describes three primary ways the alleged Catholic infiltrators used against ministers who opposed the Catholic Church: "1. Discredit him 2. Isolate him 3. Death by various means" (22).

${ }^{55}$ See Olmsted's (200 ) Real Enemies: Conspiracy Theories and American Democracy, World War I to 9/11, for an example of how conspiracy fears changed from the nineteenth to the twentieth centuries. Olmsted argues that the American involvement in the First World War, in particular, the federal government's increase in power over individuals, factored into a change in the focus of conspiracy fears. "Some Americans had worried for decades that malign forces might take over the government. Now, with the birth of the modern state, they worried that the government itself might be the most dangerous force of all" (14). Goldberg argues for a post-World War II change in conspiracy theorizing: "This period [1945 to the present] departs from the past in the 
regularity of the drumbeat, the multiplicity of messages and carriers, the number of believers, and the depth of immersion of popular culture in conspiracy thinking" (xii).

${ }^{56}$ Neither communism nor Islam is a concern in Fifty Years - Chiniquy makes a handful of references to Islam.

${ }^{57}$ The comics, however, do not construct a visionary ethos for him, in which God gives visions and voices to lead him out of the Church (although upon his conversion he is miraculously healed and removes himself from the iron lung [Alberto 20-13]). The comics also do not portray, as Fifty Years does with Chiniquy, a man on the inside of the Church who was always really on the outside (a nascent Protestant).

${ }^{58}$ See also Chick's critique of the ecumenical movement, Smokescreens (1983), in which he uses Chiniquy to support Rivera. "I can almost hear some of the comments now," Chick writes of an imagined interlocutor: "Hey, Chick, that's speculation. You only have Dr. Rivera's word on that. What proof do you have that the Vatican wants to destroy or take over the United States?"' (81). Chick then points readers to Chiniquy's Lincoln dialogues in Fifty Years (which he mentions they have reprinted). After quoting Chiniquy's Lincoln, Chick tells readers that "this completely backs up the information that Dr. Rivera has given us" (82). (I did not see this book in print; page numbers are based on comparing the table of contents, available via Google Books, to the version available on Archive.org.) Smokescreens is available here:

https://archive.org/details/Smokescreens

59 “After Abraham Lincoln's assassination, the Vatican ordered Catholic writers to immediately write Lincoln's biography and destroy his reputation and his Christian testimony. Protestant authors influenced by the Vatican made the same attack. Some of their claims were that Lincoln was supposed to be an agnostic, a mason, into séances, a free thinker, an atheist, etc., etc. [sic] They were successful! It's been reported that even today in some public schools, Catholic teachers are turning black students against Lincoln, calling him a phony. Rome never gives up" (The Big Betrayal 59). For other instances of Rivera in The Big Betrayal see pp. 37, 40, 48, 49, 64. In The Godfathers, Rivera states, "The Jesuits have captured and broken nations. They have started wars and murdered kings and presidents, including Abraham Lincoln" (9).

${ }^{60}$ Alberto $(12,15,32)$, Double-Cross $(2,12,14)$, The Godfathers $(7,9,11)$, The Force (10), Four Horsemen (25). Only The Prophet makes no references to Chiniquy in the text of the narrative (though The Big Betrayal is advertised for sale on the cover).

Though in light of the comic's emphasis on the rise of Islam, a religion very rarely even mentioned in Fifty Years, this is no surprise.

${ }^{61}$ For other examples of Chiniquy advertised via footnotes, see Alberto, pp. 12, 15, 32.

${ }^{62}$ http://www.chick.com/catalog/assortments/0931.asp

${ }^{63}$ Hunter's book is available (though without page numbers - the scan here does not reflect the printed page) here: https://archive.org/details/IsAlbertoForReal 363

(part of the book is also available on Google Books, with page numbers).

${ }^{64}$ Though not addressing Chick's specific eschatological beliefs, Crowley argues that apocalyptic belief can have a significant political impact: "If belief in the apocalyptic narrative, however unconscious, motivates politicians who hold powerful positions in government, this does not bode well for American relations with other countries because apocalyptism requires that wars among nations occur prior to the end time. Nor 
does it bode well for democracy. Christian apocalyptism devalues unbelievers, characterizing them as pawns of history, deluded secularists, or misguided apostates who are condemned to suffering, pain, and death" (115). In Arguing the Apocalypse: A Theory of Millennial Rhetoric (1994), Stephen D. O'Leary describes the debate in American studies over "the role played by apocalyptic themes and the political consequences of such beliefs in the eighteenth, nineteenth, and twentieth centuries. In the words of historian Ruth Bloch, apocalyptic 'has been interpreted as a spur to action, as a source of comfort, and as a rationale for passivity. . . Ideologically it has been judged inherently radical, "progressive," and conservative"” (12). See also Jason Dittmer's (2007) "Of Gog and Magog: The Geopolitical Visions of Jack Chick and Premillennial Dispensationalism" (294-99).

${ }^{65}$ King of Kings is available here: http://www.fmh-child.org/KingOfKings.html ${ }^{66}$ For instance, America's premiere Puritan, Jonathan Edwards, "with other American Protestants, identified the Roman Catholic pope with the Antichrist" (Goldberg 70). See also Wills pp. 40-41, 51, 78, 372-73.

${ }^{67}$ According to Jason Dittmer (2007), dispensationalism refers to a "division of biblical history into seven dispensations, or eras, each of which marks a different relationship between God and humanity" (283). Dispensationalists believe "God has two different plans for two different peoples: the Jews as a chosen earthly people and the Christian church as a chosen heavenly people." Not all premillennialists are dispensationalists. But while "separate concepts and belief in one does not require belief in the other, they are, in practice, generally found together" (282).

${ }^{68}$ For more on premillennialism, see Timothy Weber's (1999) “Dispensational Premillennialism: The Dispensationalist Era" (Christian History and Biography, issue 61), available here: http://www.ctlibrary.com/ch/1999/issue61/61h034.html. See also Paul Boyer's When Time Shall Be No More: Prophecy Belief in Modern American Culture (Harvard University Press 1992).

${ }^{69}$ Willis writes, "Most Protestant theologians before the 1880 s had been Postmillennialists in their eschatology" (356). Pointer concurs: "for most of the nineteenth century, postmillennialism was "the commonly received doctrine" among American Protestants, as one minister put it in 1859. Postmillennialism dominated the religious press, the leading seminaries, and most of the Protestant clergy, and it was ingrained in the popular mind." See also Stephen D. O'Leary's (1994) Arguing the Apocalypse: A Theory of Millennial Rhetoric, who writes of "[p]ostmillennial eschatology enjoy[ing] a long period of ascendancy and dominance in American Protestant culture" (85).

${ }^{70}$ Pointer describes postmillennialism as supporting a nineteenth-century American optimism about the future: "During most of the nineteenth century, American Protestants believed they were living in special times, that current events were hastening the coming of the Kingdom of God on earth." See also O'Leary (12, 84-85). ${ }^{71} \mathrm{O}$ 'Leary describes how scholars argue "that the premillennial interpretation of apocalyptic has led to a passive role in public affairs, if not to actual withdrawal from the public sphere, while the more optimistic postmillennial interpretation has encouraged social activism and eventually been subsumed into progressivism and American civil religion" (12). This view of the divide between the two, however, has 
been questioned, especially with the social and political activity of contemporary conservative premillennial preachers, such as Tim LaHaye, Pat Robertson, and Jerry Falwell. A potentially useful area of research would be to consider the relationships between pre- and postmillennialism, anti-Catholicism, and political involvement, especially nativism. Was nineteenth-century anti-Catholicism more nativistic not only because of the existence of mass Catholic immigration (which greatly diminished after World War I) but also because of the influence of a more politically active postmillennial view of the world's end? Does Jack Chick's lack of a more explicit political - he does not work against Catholic candidates for office-focus derive from his premillennial outlook?

72 For examples of Chick's eschatology, see his tract "The Beast" (1988), available here: http://www.chick.com/reading/tracts/0007/0007_01.asp; and his comic book Chaos (2003), available here: http://www.fmh-child.org/Chaos/Chaos.html

${ }^{73}$ The cover features the four horsemen of the apocalypse, with one being a priest and another being a pope. Four Horsemen available here: http://www.fmhchild.org/FourHorsemen.html

${ }^{74}$ A Kindle word search reveals a distinct lack of terminology associated with premillennial doctrine. The term "antichrist" is used sparingly-roughly six times in an 832-page book. There is no mention of the rapture, the tribulation, or 666, and the very words "millennium" and "millennial" do not appear once.

${ }^{75}$ For more on the role the black church played in sponsoring literacy among African Americans, see Brandt 110-123.

${ }^{76}$ See also Jacob's fifth chapter, "Oral Roberts discovers comics and Archie goes to church: Sponsoring multimodal literacy through religious comics" (127-61).

${ }^{77}$ It should be kept in mind that Chick's materials are inexpensive, with many of his tracts made available for free online. Dwayne Walker reports on his meeting with Jack Chick and concludes, "He really believes what he writes. You can argue that he is crazy, but he honestly believes his conspiracy theories. I do not regard him as a hypocrite" (Raeburn 29).

${ }^{78}$ For more on agency and conspiracy theory see Timothy Melley's Empire of Conspiracy: The Culture of Paranoia in Postwar America (2009) and Chapter Three, "Done In: Conspiracy and Agency in the Conditions of an Information Economy," in Evan Watkins (1998) Everyday Exchanges: Marketwork and Capitalist Common Sense. For Chick's highly individualistic approach to Christianity, see Massa 100-120.

79 The inside cover of The Big Betrayal advertises Chick's abbreviated Fifty Years: "Here is the finest work every written to show, from the inside, what Catholicism really is. You will feel Chiniquy's broken heart for Catholics, even as he clearly refutes Catholicism's errors. Now shortened and abridged, it is even more readable than before!" And in keeping with his use of the Chiniquy story - or any story - to bring people to a salvation experience, Chick promises, "You'll laugh and cry with Chiniquy, and find your own heart moved deepened desire to obey Christ, and Him alone."

${ }^{80}$ The majority of Phelps's book, which he now sells as CD, is available here: https://archive.org/details/VaticanAssassins_297 
${ }^{81}$ The Race is available in part here:

http://books.google.com/books?id=nMSkaA0rxMsC\&lpg=PA473\&ots=ug7oMheeii\&d $\mathrm{q}=$ The $\% 20$ race $\% 20 \mathrm{t} \% 20 \mathrm{~d} \% 20$ walters $\& \mathrm{pg}=\mathrm{PA} 460 \# \mathrm{v}=$ onepage $\& \mathrm{q} \& \mathrm{f}=$ false

${ }^{82}$ Publisher's Weekly review available here: http://www.publishersweekly.com/9780066210834

${ }^{83}$ On conspiracy theories and the Web, see also Jonathan Kay's Among the Truthers: $A$ Journey Through America's Growing Conspiracist Underground (2011), in particular Chapter Seven, "Democratizing Paranoia: How the Web Revolutionized Conspiracism" (227-260).

${ }^{84}$ Though he does not see the Web as having been an "unqualified boon to conspiracy theorists," Steve Clarke (2007) admits that it "has enabled the dissemination of many more conspiracy theories than there once were" (169).

${ }^{85}$ Price called on members to share their copies with others, and he called on local councils to purchase "all the anti-papal literature on the market and make a circulating library" for their members.

${ }^{86}$ Price was sentenced to 18 months in a California state jail and to pay $\$ 500$. He appealed to the Supreme Court and lost. The Supreme Court's ruling is available here: https://bulk.resource.org/courts.gov/c/US/165/165.US.311.625.html

${ }^{87}$ The magazine printed two pages of the book (extracts from seventeenth-century Catholic theologian Peter Dens) for which Price claimed he was imprisoned: "It was for selling a previous edition of Dens' Theology that W. E. Price was arrested, nevertheless, we are determined to publish to the world the iniquity and filth of the Romish confessional” (“The Horrible Book," March 1897, 1832).

${ }^{88}$ Nordstrom writes that Catholics in the Progressive Era used the Comstock laws, which prohibited the mailing of obscene materials, in their efforts against anti-Catholic papers: "Catholics and their supporters scoured nativist papers to identify possible avenues for legal action and exploited these to the fullest" (183). He cites as an example the former the case of Thomas E. Watson. The 1896 vice presidential candidate for the Populist Party (and future senator from Georgia) "was arrested in Georgia [June 1912] and subsequently indicted in Federal District Court ... on the charges of sending obscene materials through the mail, for printing a series of articles outlining the perversion and vice in Catholic confessionals." The anti-Catholic (as well as antiSemitic and racist) Watson described his crime as being his citation of Catholic literature: "The obscene material which I sent through the mails consisted of a portion of a theological work, a text-book in Romanist seminaries" (356). He points out that the book had been sent through the mails for a long time, and then points to Chiniquy as further support: "Father Chiniquy quoted a part of it in his great work, 'The Priest, the Woman and the Confessional," with Chiniquy's book having successfully gone "through the mails for 32 years." But for Watson, "I quoted what Chiniquy quoted, and I was arrested for it." He was eventually acquitted, and would go on to serve as a United States senator from Georgia. Watson's Magazine available here:

http://books.google.com/books?id=W czAQAAMAAJ\&dq=chiniquy\&pg=PA356\#v $=\mathrm{O}$ nepage \&q$=$ chiniquy $\& \mathrm{f}=$ false 
For more on the trial, see pp. 367-68 of C. Vann Woodward's biography, Tom Watson: Agrarian Rebel (1938) available here: https://archive.org/details/AgrarianRebel1938BiographyOfTomWatson

${ }^{89}$ Noll remarks that while the sale of Alberto in the early 1980s suggests that "latent antagonisms remain in Protestant circles," evangelical denunciations of Chick, the C.B.A.'s response, and the fact that it was evangelical journalists who did much to expose Rivera are all "indications of changing times" in the Protestant/Catholic divide (74). Something with which Chick would no doubt agree and no doubt not approve.

${ }^{90}$ For resources on anti-Catholicism on the Web, see Robert Lockwood's "AntiCatholicism on the Net," available here:

http://www.catholicculture.org/culture/library/view.cfm?recnum=3604; David CruzUribe's "Anti-Catholicism on the Net," available here:

http://shakti.trincoll.edu/ dcruzuri/anti-catholic/anti-catholic.html; and Mark

Weitzman's 1998 speech, "The Inverted Image: Anti-Semitism and Anti-Catholicism on the Internet," available here:

http://www.bc.edu/dam/files/research_sites/cjl/texts/cjrelations/resources/articles/weitz man.htm\# edn50

${ }^{91}$ https://www.facebook.com/pages/Fifty-Years-in-the-Church-of-

Rome/105396722834319

${ }^{92}$ https://www.facebook.com/pages/Charles-Chiniquy/132817093422170. You can also like Alberto Rivera: https:/www.facebook.com/pages/Alberto-

Rivera/107773109251476. And Chick Publications has its own page:

https://www.facebook.com/chicktracts

${ }^{93}$ See

https://www.facebook.com/permalink.php?id=173329486085412\&story fbid $=5004243$ 90042585 and

https://www.facebook.com/permalink.php?id=173329486085412\&story fbid=5029307 16458619

${ }^{94} \mathrm{http}: / /$ en.wikipedia.org/wiki/Charles_Chiniquy

95 Some sites that host Fifty Years: http://www.biblebelievers.com/chiniquy/; http://www.whatsaiththescripture.com/Voice/Fifty.Years.Church.Rome.html;

http://www.whitehorsemedia.com/books/\#.Ux6CCV5w3go;

http://avenueoflight.com/2010/11/632/;

http://www.slideshare.net/BrianClaytonCharles/fifty-years-in-the-church-of-rome-bycharles-chiniquy;

http://www.forgottenbooks.org/books/Fifty_Years_in_the_Church_of_Rome_10002430

63; http://jesus-is-lord.com/fiftyc.htm

${ }^{96} \mathrm{http}: / /$ www.amazon.com/Fifty-Years-Church-Conversion-

Priest/dp/0937958212/ref $=$ sr 1 1 ie $=U T F 8 \& q i d=1394508812 \& s r=8$ -

$1 \&$ keywords $=$ fifty + years + in + the + church + of + rome

${ }^{97} \mathrm{http}: / / \mathrm{www}$.ianpaisley.org/article.asp?ArtKey=mary2

$98 \mathrm{http}: / / \mathrm{www}$. ianpaisley.org/article.asp?ArtKey=gore

99 http://www.youtube.com/watch?v=TZI0y71AyrA

100 "The Jesuits and the Assassination of Abraham Lincoln," available here:

http://www.youtube.com/watch?v=K1ngdqncj5Q; "The Assassination of Abraham 
Lincoln by the Jesuits," available here:

http://www.youtube.com/watch?v=JQTbuF6vCUA; "Rome's Responsability [sic] of the Assassination of Abraham Lincoln," available here:

http://www.youtube.com/watch?v=8DVOvtbTjL8; "Lincoln Assassination The Jesuit Catholic Connection," available here:

http://www.youtube.com/watch?v=kwF7ELzlha4; "Civil War, The Vatican, And The Assassination Of Abraham Lincoln," available here:

http://www.youtube.com/watch?v=EBD9UnNPCfA; "Higherside Chats 29: The

Lincoln Assassination \& the Catholic Church w/ Paul Serup," available here:

http://www.youtube.com/watch?v=anLjsxRLX4w; "Re: Lincoln Assassination - The

Jesuit - Catholic Connection," available here:

http://www.youtube.com/watch?v=gtuzxIXfAtg; "Pope Francis and Jesuit Order (pt 1)," which uses footage from the recent Spielberg film on Lincoln (11:25), available here: http://www.youtube.com/watch?v=aIj6AMwLa4U

${ }^{101} \mathrm{http}$ ://forum.prisonplanet.com/index.php?topic=25451.5; wap2

102 "He was everybody, grown a little taller" is available here:

https://repository.library.brown.edu/studio/item/bdr:78003/

${ }^{103}$ Poll was taken September $25^{\text {th }}$ and $26^{\text {th }}$, surveying 790 registered voters. Margin of error was $+/-3.5 \%$.

${ }^{104}$ Both the Boston Marathon bombing (April 15, 2013) and the Newton, Connecticut mass shooting (December 14, 2012) have been described as "false flag" events. See Alex Jones's “Government Caught in Boston Bombing False Flag Cover-Up," available at http://www.infowars.com/government-caught-in-boston-bombing-false-flag-coverup/; see InfoSalvo's "Newtown Connecticut Elementary Shooting Is A Staged False Flag Against Gun Owners and Preppers," available at http://www.infosalvo.com/usnews/newton-connecticut-elementary-shooting-is-a-staged-false-flag/. 


\section{REFERENCES}

Aaronovitch, David. Voodoo Histories: The Role of the Conspiracy Theory in Shaping Modern History. London: Jonathan Cape, 2009. Print.

Addams, Jane. Twenty Years at Hull-House: With Autobiographical Notes. New York: Macmillan, 1910. Print.

“A Despicable Device.” Los Angeles Herald 31 Oct. 1890: 4. Print.

Alexander, Jeffrey C., Ron Eyerman, David Inglis, and Philip Smith. “Series Editors' Foreword." The Cultural Sociology of Political Assassination: From MLK and RFK to Fortuyn and van Gogh. Ron Eyerman. New York: Palgrave Macmillan, 2011. Print. Alvarez, David J. "The Papacy in the Diplomacy of the American Civil War." The Catholic Historical Review 69.2 (Apr. 1983): 227-48. JSTOR. Web. 6 Apr. 2012.

Amossy, Ruth. "Ethos at the Crossroads of Disciplines: Rhetoric, Pragmatics, Sociology." Poetics Today 22.1 (2001): 1-23. Print.

Anderson, Dana. Identity's Strategy: Rhetorical Selves in Conversion. Columbia: U of South Carolina P, 2007. Print.

An Indignant Protestant. “Romanism.” New York Evangelist 27 May 1869 (40, 21): 6. American Periodical Series Online. 
Anstruther, G. Elliot. “The Protestant Platform.” London: Catholic Truth Society, 1915. Print. “A.P.A. Principles, As Adopted at Des Moines Iowa, and Readopted at Milwaukee in May

1895. A.P.A. Magazine 1.1 (June 1895): 88. Print.

Appleton, Sheldon. "Assassinations." Public Opinion Quarterly 64.4 (2000): 495-522. Academic Search Premier. Web. 5 Sept. 2013.

Archosz. "JFK about 9/11 and the emergence of a New World Order." Online video clip. YouTube. YouTube, 23 June. 2007. Web. 28 Jan. 2014.

Aristotle. On Rhetoric: A Theory of Civic Discourse. Trans. George A. Kennedy. New York: Oxford UP, 2006. Print.

Augustine. On Christian Doctrine, Book IV. Trans. Thérèse Sullivan. The Rhetorical Tradition: Readings from Classical Times to the Present. 2nd ed. Ed. Patricia Bizzell and Bruce Herzberg. Boston: Bedford/St. Martins, 2001. 456-185. Print.

Barkun, Michael. A Culture of Conspiracies: Apocalyptic Visions in Contemporary America. Berkeley: U of California P, 2003. Print.

Baumlin, James S. "Ethos.” Encyclopedia of Rhetoric. Ed. Thomas O. Sloane. New York: Oxford UP, 2001. 263-77. Print.

---. "Introduction: Positioning Ethos in Historical and Contemporary

Theory." Ethos: New Essays in Rhetorical and Critical Theory. Ed. James S. Baumlin and Tita French Baumlin. Dallas: Southern Methodist P, 1994. xi-xxxi. Print.

Beecher, Edward. The Papal Conspiracy Exposed, and Protestantism Defended, in the Light of Reason, History \& Scripture. New York: M. W. Dodd, 1855. Print. Beecher, Lyman. A Plea for the West. Cincinnati: Truman \& Smith, 1835. Print. 
Bell, David Lynn. Tracts to Christ: An Evaluation of American Gospel Tracts. Diss. Southern Baptist Theological Seminary, 2005. Ann Arbor: UMI, 2006. 3194779. Print.

Bell, J. Bowyer. Assassin: Theory and Practice of Political Violence. New Brunswick: Transaction Publishers, 2006. Print.

Bernard-Donals, Michael. "Ethos, Witness, and Holocaust ‘Testimony’: The Rhetoric of 'Fragments.'" JAC. 20.3 (2000): 565-582. Print.

Berton, Pierre. My Country: The Remarkable Past. Toronto: McClelland Stewart, 1976. Print.

Bennett, David H. Party of Fear: From Nativist Movements to the New Right in American History. Chapel Hill: U of North Carolina P, 1988. Print.

---. "Nativism." The Princeton Encyclopedia of American Political History. Ed. Michael Kazin, Rebecca Edwards, and Adam Rothman. Vol. 1. Princeton: Princeton University Press, 2010. Print. 521-28.

“Biography of Jack Chick.” Chick Publications (2014). Web. 7 February 2014. $<$ http://www.chick.com/information/authors/chick.asp>.

Billington, Ray Allen. The Protestant Crusade, 1800-1860: A Study of the Origins of American Nativism. New York: Macmillan, 1961. Print.

Bivins, Jason. Religion of Fear: The Politics of Horror in Conservative Evangelicalism. Oxford: Oxford UP, 2008. Print.

Bizzell, Patricia. "Frances Willard, Phoebe Palmer, and the Ethos of the Methodist Woman Preacher." Rhetoric Society Quarterly 36.4 (2006): 377-398. Print. Blair, J. Anthony. "The Rhetoric of Visual Arguments.” Defining Visual Rhetorics. Ed. Charles A. Hill and Marguerite H. Helmers. Mahwah: Lawrence Erlbaum, 2004. 41-61. Print. 
Blight, David W. Race and Reunion: The Civil War in American Memory. Cambridge: The Belknap Press of Harvard UP, 2001. Print.

---. Rev. of Lincoln in American Memory. The Journal of American History 81.3 (Dec. 1994): 1265-1267. Print.

Boeree, C. George. "Psychology: The Beginnings.” C. George Boeree (2000). Web. 23 March 2014. < http://webspace.ship.edu/cgboer/psychbeginnings.html>.

Borer, Michael I, and Adam Murphree. "Framing Catholicism: Jack Chick's Anti-Catholic Cartoons and the Flexible Boundaries of the Culture Wars." Religion and American Culture: a Journal of Interpretation. 18.1 (2008): 95-112. Print.

Brandt, Deborah. Literacy in American Lives. New York: Cambridge UP, 2001. Print.

Brown, Candy G. The Word in the World: Evangelical Writing, Publishing, and Reading in America, 1789-1880. Chapel Hill: University of North Carolina Press, 2004. Print.

Brown, Thomas M. 'The Image of the Beast: Anti-Papal Rhetoric in Colonial America." Ed. Richard O. Curry and Thomas M. Brown. Conspiracy: The Fear of Subversion in American History. New York: Holt, Rinehart and Winston, 1972. 1-20. Print.

Brumberger, Eva. "The Rhetoric of Typography: Effects on Reading Time, Reading Comprehension, and Perceptions of Ethos." Technical Communication. 51.1 (2004). Print.

Burke, Kenneth. “The Rhetoric of Hitler's 'Battle.” The Philosophy of Literary Form: Studies in Symbolic Action. 3rd. ed. Berkeley: U of California P, 1973: 191-220. Print.

Burlingame, Michael. Abraham Lincoln: A Life. Vol. I. Baltimore: Johns Hopkins UP, 2008. Print.

Byrne, Patricia. "American Ultramontanism." Theological Studies. 56.2 (1995). Print. 
301-26.

Castillo, Dennis. “Jesuits.” Conspiracy Theories in American History: An Encyclopedia. Peter Knight ed. Santa Barbara: ABC-CLIO, 2003. 369-71. Print.

Chamberlain, Charles. "From Haunts to Character: The Meaning of Ethos and Its Relation to Ethics.” Helios 11 (1984): 97-108. Print.

Cheng, Martha S. "Colin Powell's Speech to the UN: A Discourse Analytic Study of Reconstituted Ethos." Rhetoric Society Quarterly 42.5 (2012): 424-449. Print.

Cherry, Rodger D. "Ethos vs. Persona: Self Representation in Written Discourse." Written Communication 15:3 (1998): 384-410. Print.

Chick, Jack T. Alberto. Ontario, CA: Chick Publications, 1978. Print.

---. Double-Cross. Ontario, CA: Chick Publications, 1981. Print.

---. King of Kings. Ontario, CA: Chick Publications, 1980. Print.

---. Smokescreens. Chino: Chick Publications, 1983. Print.

---. The Big Betrayal. Ontario, CA: Chick Publications, 1981. Print.

---. The Force. Ontario, CA: Chick Publications, 1983. Print.

---. The Four Horsemen. Ontario, CA: Chick Publications, 1985. Print.

---. The Godfathers. Ontario, CA: Chick Publications, 1983. Print.

---. The Prophet. Ontario, CA: Chick Publications, 1988. Print.

Chiniquy, Charles. “Capturing American Cities.” A.P.A. Magazine 3.9 (June 1897): 55-58.

Print.

---. "Dedication to the American Edition." Fifty Years in the Church of Rome.

Toronto: William Briggs, n. d. (1888?). iii-vii. Print.

---. Fifty Years in the Church of Rome. Chicago: Adam Craig, 1888. Print. 
---. Forty Years in the Church of Christ. Chicago: Fleming H. Revell Company, 1900. Print.

---. Letter to Robert Todd Lincoln. 7 Sept. 1885. Chiniquy Collection (O3, Family Letters, 017e), Allan Pequegnat, Elliot Lake, Ontario, Canada.

Chivers, Tom. "Internet rules and laws: the top 10, from Godwin to Poe." The Telegraph. Telegraph Media Group Limited, 23 Oct. 2009. Web. 23 Dec. 2013.< http://www.telegraph.co.uk/technology/news/6408927/Internet-rules-and-laws-the-top10-from-Godwin-to-Poe.html>.

Christian, John T. America or Rome, Which? Louisville: Baptist Book Concern, 1895. Print.

Clark, Constance Aerson. "Evolution for John Doe: Pictures, the Public, and the Scopes Trial Debate." The Journal of American History. 87.4 (2001): 1275-1303. Print.

Clarke, Asia Booth. The Unlocked Book: A Memoir of John Wilkes Booth by his sister Asia Booth Clarke. New York: G. P. Putnam's Sons, 1938. Print.

Clarke, James W. Defining Danger: American Assassins and the New Domestic Terrorists. New Brunswick, N.J: Transaction Publishers, 2007. Print.

Clarke, Steve. "Conspiracy Theories and the Internet: Controlled Demolition and Arrested Development." Episteme: A Journal of Social Epistemology 4.2 (2007): 167-180.

---. “Conspiracy Theories and Conspiracy Theorizing." Philosophy of the Social Sciences 32 (2002): 131-150. Print.

Colley, Linda. Britons: Forging the Nation, 1707-1837. New Haven: Yale UP, 2005. Print.

Collins, R. G. W. Letter. A.P.A. Magazine 1.4 (Sept. 1895): 401-02. Print.

Creps III, Earl George. “The Conspiracy Argument as Rhetorical Genre.” Diss. 
Northwestern U. 1980. Ann Arbor: UMI, 1980. Print.

Crotty, William J. "Assassinations and their Interpretation within the American Context." Assassinations and the Political Order. Ed. William J. Crotty. New York: Harper \& Row, 1971. 3-53. Print.

Crowley, Sharon. Toward a Civil Discourse: Rhetoric and Fundamentalism. Pittsburgh: U of Pittsburgh P, 2006. Print.

“David Icke Biography 1.” David Icke Books, n. d. Web. 8 July 2013. $<\mathrm{http}: / /$ www.davidickebooks.co.uk/index.php?act=viewDoc\&docId=1 $>$.

“David Icke Biography 2.” David Icke Books, n. d. Web. 8 July 2013.

$<$ http://www.davidickebooks.co.uk/index.php?act=viewDoc\&docId=6>.

“David Icke Info.” Facebook.com. n. d. Web. 8 July 2013.

$<$ https://www.facebook.com/davidicke/info $>$.

Davis, David Brion. "Some Themes of Counter Subversion: An Analysis of Anti-Masonic, Anti-Catholic, and Anti-Mormon Literature.” Mississippi Valley Historical Review. 47 (September 1960): 205-224. Print.

Dean, Jodi. Aliens In America: Conspiracy Cultures from Outerspace to Cyberspace. Ithaca: Cornell UP, 1997. Print.

“Degrading Warfare of A.P.A. Forged Incendiary Literature the Favorite Weapon.” The New York Times (June 1, 1894): 1. Print.

DeLillo, Don. Running Dog. New York: Knopf, 1978. Print.

DePalma, Margaret C. Dialogue on the Frontier: Catholic and Protestant Relations 17931883. Kent: Kent State UP, 2004. Print.

Desmond, Humphrey J. The A.P.A. Movement: A Sketch. Washington: The New Century Press, 
1912. Print.

Dittmer, Jason. "Of Gog and Magog: The Geopolitical Visions of Jack Chick and Premillennial Dispensationalism" ACME: An International E-Journal for Critical Geographies 6.2 (2007): 278-303.

Dolan, Jay. "Catholic Attitudes Toward Protestants." Uncivil Religion: Interreligious Hostility in America. Ed. Robert N. Bellah and Frederick E. Greenspahn. New York: Crossroad, 1987. Print.

Drury, Marjule Anne. "Anti-Catholicism in Germany, Britain, and the United States: A Review and Critique of Recent Scholarship.” Church History 70.1 (March 2011): 98131. Print.

E. E. F. "Maligning Converted Priests. Is It Patriotism or Disguised Jesuitism?” A.P.A. Magazine 391 (June 1897): 75-76. Print.

Emerson, Jason. Giant in the Shadows: The Life of Robert T. Lincoln. Carbondale: Southern Illinois UP, 2012. Print.

Farrell, Thomas B. Norms of Rhetorical Culture. New Haven: Yale UP, 1993. Print.

“Father Chiniquy Is Dead.” The New York Times. Jan. 17, 1899. PDF.

Federman, Cary. "Between Structure And Agency: Assassination, Social Forces, And The Production Of The Criminal Subject." History Of The Human Sciences 24.5 (2011): 7388. Academic Search Premier. Web. 5 Sept. 2013.

Fehrenbacher, Don E. and Virginia Fehrenbacher. Recollected Words of Abraham Lincoln. Ed. Don E. Fehrenbacher and Virginia Fehrenbacher Stanford: Stanford UP, 1996. Print. ---. "Introduction." Recollected Words of Abraham Lincoln. Ed. Don E. Fehrenbacher and Virginia Fehrenbacher Stanford: Stanford UP, 1996. xliii-liv. Print. 
Fenster, Julie M. The Case of Abraham Lincoln: A Story of Adultery, Murder, and the Making of a Great President. New York: Palgrave Macmillan, 2007. Print.

Fenster, Mark. Conspiracy Theories: Secrecy and Power in American Culture. $2^{\text {nd }}$ ed. Minneapolis: U of Minnesota P, 2008. Print.

Fenton, Elizabeth. Religious Liberties: Anti-Catholicism and Liberal Democracy in NineteenthCentury U.S. Literature and Culture. New York: Oxford UP, 2011.

Fish, Carl. "Lincoln and Catholicism.” The American Historical Review 24.4 (July 1924). JSTOR. Accessed 6/25/13. Web.

Ford, Franklin L. Political Murder: From Tyrannicide to Terrorism. Cambridge: Harvard UP, 1985. Print.

Franchot, Jenny. Roads to Rome: The Antebellum Protestant Encounter with Catholicism. Berkeley. U of California P, 1994. Print.

Fredal, James. "The Language of Delivery and the Presentation of Character: Rhetorical Action in Demosthenes' Against Meidias.” Rhetoric Review 3/4 (2001): 251-67.

Fresenborg, Bernard. Thirty Years in Hell: Or, From Darkness to Light. St. Louis: NorthAmerican Book House, 1904. Project Gutenberg (23 March 2006). ibook file.

“"Friend' writes to inquire.” Evening Star 19 Feb. 1890: 4, col. 1.

Frobish, Todd. "An Origin of a Theory: A Comparison of Ethos in the Homeric Iliad with That Found in Aristotle's Rhetoric." Rhetoric Review 22.1 (2003): 16-30. Print.

Fulton, Justin D. Fulton, Justin D. “Rome’s Inquisition. It Was Not More Terrible In The Dark Ages Than It Is To-Day.” A.P.A. Magazine 1.1 (June 1895): 53-57. Print.

---. Washington in the Lap of Rome. Boston: W. Kellaway, 1888. Print.

Gagnon, Serge. “Dionne, Amable.” Dictionary of Canadian Biography, vol. 8, University of 
Toronto/Université Laval, 2003. Web.

Genette, Gérard. Paratexts: Thresholds of Interpretation. Cambridge: Cambridge University Press, 1997. Print.

George, Joseph Jr. "The Lincoln Writings of Charles P. T. Chiniquy.” Journal of the Illinois State Historical Society. 69 (Feb. 1976): 17-25. Web. 14 Oct. 2009. PDF.

Gjerde, Jon. Catholicism and the Shaping of 19th Century America. Ed. S D. Kang. Cambridge: Cambridge UP, 2012. Print.

Gladden, Washington. Recollections. Boston: Houghton Mifflin Co, 1909. Print.

Goldberg, Robert A. Enemies Within: The Culture of Conspiracy in Modern America. New Haven: Yale UP, 2001. Print.

Goldwag, Arthur. The New Hate: A History of Fear and Loathing on the Populist Right. New York: Pantheon Books, 2012. Print.

Graumann, Carl F, and Serge Moscovici, eds. Changing Conceptions of Conspiracy. New York: Springer-Verlag, 1987. Print.

Greeley, Horace. Greeley on Lincoln: With Mr. Greeley's Letters to Charles A. Dana and a Lady Friend; to Which Are Added Reminiscences of Horace Greeley. Ed. Joel Benton. New York: Baker \& Taylor Co, 1893. Print.

Griffin, Susan M. Anti-Catholicism and Nineteenth-Century Fiction. New York: Cambridge UP, 2004. Print.

Gutjahr, Paul C. "Diversification in American Religious Publishing." A History of the Book in America, Volume 3: the Industrial Book, 1840-1880. Ed. Scott E. Casper, Jeffrey D. Groves, Stephen W. Nissenbaum, and Michael Winship. Chapel Hill, NC: U of North Carolina P--American Antiquarian Society, 2007. 194-203. Print. 
Hanchett, William. The Lincoln Murder Conspiracies. Urbana: U of Illinois P, 1983.

Harvill, Jerry G. Aristotle's Concept of Ethos As Ground for a Modern Ethics of

Communication. Ann Arbor: University Microfilms International, 1990. Print.

Halloran, S. Michael. “Aristotle's Concept of Ethos, or If Not His Somebody Else's." Rhetoric Review 1.1 (1982): 58-63. Print.

Hauser, Gerald A. Introduction to Rhetorical Theory. Prospect Heights: Waveland Press, 1986. Print.

Havens, Murray C, Carl Leiden, and Karl M. Schmitt. The Politics of Assassination. Englewood Cliffs: Prentice-Hall, 1970. Print.

Higham, John. Strangers in the Land: Patterns of American Nativism, 1860-1925. $2^{\text {nd }}$ ed. New Brunswick: Rutgers UP, 1988. Print.

Hill, Charles A., and Marguerite H. Helmers. "Preface.” Defining Visual Rhetorics. Ed. Charles A. Hill and Marguerite H. Helmers. Mahwah: Lawrence Erlbaum, 2004. ix-xi. Print.

Hirst, Russel. "Ethos and the Conservative Tradition in Nineteenth-Century American Protestant Homiletics." Ethos: New Essays in Rhetorical and Critical Theory. Ed. James S. Baumlin and Tita French Baumlin. Dallas: Southern Methodist P, 1994. Print. 293-318.

“The History of Fleming H. Revell.” Baker Publishing Group, n. d. Web. 8 July 2013. $<$ http://bakerpublishinggroup.com/revell/about-revell $>$.

Hocks, Mary E. "Understanding Visual Rhetoric in Digital Writing Environments." College Composition and Communication. 54.4 (2003): 629-656. Print.

Hofstadter, Richard. The Paranoid Style in American Politics, and Other Essays. Chicago: University of Chicago Press, 1979. Print. 
Hogan, William. A Synopsis of Popery, As It Was and As It Is. Boston: Redding \& Co., 1845. Print.

Holiday, Judy. "In[ter]vention: Locating Rhetoric's Ethos." Rhetoric Review 28.4 (2009): 388405. Print.

Hubbard, Elbert. “A New Disease.” The Arena 10 (June 1894): 76-83. Print.

Hunter, Sidney. Is Alberto Real? Ontario, CA: Chick Publications, 1988. Print.

Hyde, Michael J., ed. The Ethos of Rhetoric. Columbia: U of South Carolina P, 2004. Print.

Ingersoll, Robert G. The Works of Robert G. Ingersoll. Vol. IX. New York: The Dresden Publishing Company, 1901. Print.

Isocrates. Isocrates. Trans. George Norlin. Vol. 2. Cambridge: Harvard UP, 1929. Print.

Ito, Robert. "Fear Factor: Jack Chick Is the World's Most Published Author-And One of the Strangest." Los Angeles (May 2003): 56-63. Print.

Jackson, Myra M. “Abe Lincoln on 'Conspiracy Theories.” Originally from the newsletter, someoftheabovenews@yahoo.com (n.d.).Web.28 Jan. 2014.

$<$ http://911blogger.com/news/2009-05-01/abe-lincoln-conspiracy-theories $>$.

Jacobs, Dale. "Marveling at "the Man Called Nova": Comics As Sponsors of Multimodal Literacy." College Composition and Communication. 59.2 (2007): 180-205. Print.

James, Henry. The Europeans. Ed. Ian Campbell Ross. New York: Oxford UP, 1985. Print. Jameson, Fredric. "Cognitive Mapping.” Marxism and the Interpretation of Culture. Eds. Cary Nelson and Lawrence Grossberg. Urbana: U of Illinois P, 1988. 347-60. Print.

Jarratt, Susan C. and Nedra Reynolds. "The Splitting Image: Contemporary Feminisms and the Ethics of Ethos." Ethos: New Essays in Rhetorical and Critical Theory. Ed. James S. Baumlin and Tita French Baumlin. Dallas: Southern Methodist P, 1994. Print. 37-63. 
Jasinski, James. Sourcebook on Rhetoric: Key Concepts in Contemporary Rhetorical Studies. Thousand Oaks, Calif: Sage Publications, 2001. Print.

John Hancock Mutual Life Insurance Company. "He was everybody, grown a little taller." Brown Digital Repository. Brown University Library. 1952. Web. 11 March 2014. $<$ https://repository.library.brown.edu/studio/item/bdr:78003/>.

Johnson, Nan. "Ethos and the Aims of Rhetoric." Essays on Classical Rhetoric and Modern Discourse. Ed. Robert J. Connors, Lisa S. Ede, and Andrea A. Lunsford. Carbondale: Southern Illinios UP, 1984. Print. 98-114.

---. "Ethos." Encyclopedia of Rhetoric and Composition: Communication from Ancient Times to the Information Age. Ed. Theresa Enos. New York: Garland Pub, 1996. Print. $243-45$.

Kaestle, Carl F. and Janice A. Radway. "A Framework for the History of Publishing and Reading in the United States, 1880-1940." A History of the Book in America, Volume 4: Print in Motion: the Expansion of Publishing and Reading in the United States, 18801940. Ed. Carl F. Kaestle and Janice A. Radway Chapel Hill, NC: U of North Carolina P, 2009. 7-21. Print.

Kaplan, Richard L. "From Partisanship to Professionalism: The Transformation of the Daily Press." A History of the Book in America, Volume 4: Print in Motion: the Expansion of Publishing and Reading in the United States, 1880-1940. Ed. Carl F. Kaestle and Janice A. Radway Chapel Hill, NC: U of North Carolina P, 2009. 116-39. Print.

Karp, Walter. Indispensable Enemies: The Politics of Misrule in America. Baltimore: Penguin Books, 1974. Print.

Katz, Steven B. "The Ethic of Expediency: Classical Rhetoric, Technology, and the Holocaust." 
College English. 54.3 (1992): 255-275. Print.

Kauffman, Michael W. American Brutus: John Wilkes Booth and the Lincoln Conspirators. New York: Random House, 2004. Print.

Kay, Jonathan. Among the Truthers: A Journey Through America's Growing Conspiracist Underground. New York: Harper, 2011. Print.

Kennedy, John F. "The President and the Press." Bureau of Advertising, American Newspaper Publishers Association, New York, NY. 27 April 1961. John F. Kennedy Presidential Library and Museum. Web. 28 Jan. 2014. $<$ http://www.jfklibrary.org/Research/Research-Aids/JFK-Speeches/AmericanNewspaper-Publishers-Association_19610427.aspx>.

Kennedy, George A. Classical Rhetoric and Its Christian and Secular Tradition. Chapel Hill: U of North Carolina P, 1999. Print.

Keyes, Ralph. "Nice Guys Finish Seventh": False Phrases, Spurious Sayings, and Familiar Misquotations. New York, NY: HarperCollinsPublishers, 1992. Print.

Kjeldsen Jens E. "Talking to the Eye: Visuality in Ancient Rhetoric." Word \& Image. 19.3 (2003): 133-137. Print.

Kinneavy, James L. and Susan C. Warshauer. "From Aristotle to Madison Avenue: Ethos and the Ethics of Argument." Ethos: New Essays in Rhetorical and Critical Theory. Ed. James S. Baumlin and Tita French Baumlin. Dallas: Southern Methodist P, 1994. Print. $171-90$.

Kinzer, Donald L. An Episode in Anti-Catholicism: The American Protective Association. Seattle: U of Washington P, 1964. Print.

Knight, Peter. Conspiracy Culture: From Kennedy to the X-Files. New York: Routledge, 2000. 
Print.

Knobel, Dale T. America for the Americans: The Nativist Movement in the United States. New York: Twayne, 1996. Print.

LaGrandeur, Kevin. "Digital images and classical persuasion." Eloquent Images: Word and Image in the Age of New Media. Ed. Mary E. Hocks and Michelle R. Kendrick. Cambridge: MIT Press, 2003. 117-136. Print.

Lannin, W. H. "Trailing the Historical Snake, Jesuitism.” A.P.A. Magazine 1.1 (June 1895): 4849. Print.

Laverdure, Paul. "Charles Chiniquy: The Making of an Anti-Catholic Crusader.” CCHA Historical Studies. 54 (1987): 39-56. PDF.

Lears, Jackson. The Rebirth of a Nation: The Making of Modern America, 1877-1920. New York: HarperCollins, 2009. Print.

Leonard, Elizabeth D. Lincoln's Avengers: Justice, Revenge, and Reunion After the Civil War. New York: W.W. Norton \& Co, 2004. Print.

Levine, Robert S. Conspiracy and Romance: Studies in Brockden Brown, Cooper, Hawthorne, and Melville. Cambridge: Cambridge UP, 1989. Print.

Leyden, Thomas. "Ex-Priests and the A.P.A.” A.P.A. Magazine 1.1 (June 1895): 63-65. Print. Lindon, Frank. “The Pope's New Departure in American Politics.” A.P.A. Magazine 1.1 (June 1895): 35-40. Print.

Lincoln, Abraham. Abraham Lincoln; Complete Works, Comprising His Speeches, State Papers, and Miscellaneous Writings. Vol. I. Ed. John G. Nicolay and John Hay. New York: Century, 1920. Print.

Lincoln, Abraham, Don E. Fehrenbacher, Roy P. Basler, and Roy P. Basler. Speeches and 
Writings, 1859-1865: Speeches, Letters, and Miscellaneous Writings, Presidential Messages and Proclamations. New York: Library of America, 1989. Print.

---. Speeches and Writings, 1832-1858: Speeches, Letters, and Miscellaneous Writings, The Lincoln-Douglas Debates. New York: Library of America, 1989. Print.

Lincoln, Robert. Letter to Charles Chiniquy. 10 Sept. 1885. Chiniquy Collection (O7, Letters to Chiniquy and Family, 187e), Allan Pequegnat, Elliot Lake, Ontario, Canada.

Losh, Elizabeth M, Jonathan Alexander, Kevin Cannon, and Zander Cannon. Understanding Rhetoric: A Graphic Guide to Writing. New York: Bedford/St. Martin's, 2013. Print. Lougheed, Richard. The Controversial Conversion of Charles Chiniquy. Toronto: Clements Academic, 2008. Print.

Maier, Pauline. "The Pope at Harvard: the Dudleian Lectures, Anti-Catholicism, and the Politics of Protestantism.” Proceedings of the Massachusetts Historical Society. 97 (1985): 16-41. Print.

Malcom, Allison O'Mahen. "Anti-Catholicism and the Rise of Protestant Nationhood in North America, 1830--1871.” Order No. 3472399 U of Illinois at Chicago, 2011. Ann Arbor: ProQuest. Web. 25 June 2013.

Marchant, Brandi S. Defined by What We Are Not: the Role of Anti-Catholicism in the Formation of Early American Identity. Diss. Liberty University, 2012. Ann Arbor: UMI, 2012. Print.

Marty, Martin E. Pilgrims in Their Own Land: 500 Years of Religion in America. Boston: Little, Brown, 1984. Print.

Massa, Mark S. Anti-Catholicism in America: The Last Acceptable Prejudice. New York: Crossroad Publishing, 2003. Print. 
Mason, Fran. "Mind Control." Conspiracy Theories in American History: An Encyclopedia.

Ed. Peter Knight. Santa Barbara, Calif: ABC-CLIO, 2003. 480-89. Print.

Mattingly, Carol. "Beyond the Protestant Literacy Myth.” In Press.

---."Uncovering Forgotten Habits: Anti-Catholic Rhetoric and Nineteenth-Century American Women’s Literacy.” College Composition and Communication 58.2 (Dec. 2006): 160181. Print.

Maury, Reuben. The Wars of the Godly. New York: R. M. McBride \& Co, 1928. Print. May, James M. Trials of Character: The Eloquence of Ciceronian Ethics. Chapel Hill: U of North Carolina P, 1988. Print.

McConville, Brendan. The King's Three Faces: The Rise \& Fall of Royal America, 1688-1776.

Chapel Hill: Published for the Omohundro Institute of Early American History and Culture, Williamsburg, Virginia, by the U of North Carolina P, 2006. Print.

McGreevy, John T. Catholicism and American Freedom. New York: Norton, 2003. Print.

Melley, Timothy. Empire of Conspiracy: The Culture of Paranoia in Postwar America. Ithaca: Cornell UP, 2000. Print.

Metz, Gary. "Jack Chick’s Anti-Catholic Alberto Comic Book Is Exposed as a Fraud." Christianity Today 52 (13 March 1981): 50-53 [354-57]. Print.

Miller, Carolyn R. "The Presumptions of Expertise: the Role of Ethos in Risk Analysis." Configurations 11.2 (2004): 163-202. Print.

---."Writing in a Culture of Simulation: Ethos Online.” The Semiotics of Writing: Transdisciplinary Perspectives on the Technology of Writing. Ed. Patrick Coppock. Turnhout, Belgium: Brepols, 2001. 253-279. PDF.

Moloney, Dierdra M. “Combatting 'Whiskey’s Work': The Catholic Temperance Movement in 
Late Nineteenth-Century America.” U. S. Catholic Historian 16.3 (Summer 1998): 123. JSTOR. Web. 8 July 2013.

Monk, Maria. Awful Disclosures of the Hotel Dieu Nunnery of Montreal, Revised, With an Appendix. 1836. New York: Arno, 1977. Print.

Morgan, David. Protestants \& Pictures: Religion, Visual Culture, and the Age of American Mass Production. New York: Oxford UP, 1999. Print.

---. The Sacred Gaze: Religious Visual Culture in Theory and Practice. Berkely: U of California P, 2005. Print.

---. Visual Piety: A History and Theory of Popular Religious Images. Berkeley: U of California P, 1998. Print.

Morris, Charles R. American Catholic: The Saints and Sinners Who Built America's Most Powerful Church. New York: Times Books, 1997. Print.

Neely, Jr., Mark E. “Come Retribution, A Review.” American Historical Review 95.3 (June 1990): 913-14.

---. "Richard W. Thompson: The Persistent Know Nothing." Indiana Magazine of History 72.2 (June 1976): 95-122. JSTOR. Web. 23 Nov. 2013.

---. The Abraham Lincoln Encyclopedia. New York: McGraw-Hill Book Company, 1982. Print.

Nelson, Lean. "Pastor Apologizes for Hate-filled Halloween Hand-out."splcenter.org Southern Poverty Law Center, 2 Nov. 2011. Web. 7 Mar. 2014. $<$ http://www.splcenter.org/blog/2011/11/02/pastor-apologizes-for-hate-filledhalloween-hand-out/>.

Nelson, Michael. "Fighting For Lincoln's Soul." Virginia Quarterly Review 79.4 (2003): 607623. Academic Search Premier. Web. 5 Sept. 2013. 
Noel, Jan. "Dry Patriotism: The Chiniquy Crusade." Canadian Historical Review. 71.2 (1990): 189-207. PDF file.

Noll, Mark A, and Carolyn Nystrom. Is the Reformation Over?: An Evangelical Assessment of Contemporary Roman Catholicism. Grand Rapids, Mich: BakerAcademic, 2005. Print.

Nordstrom, Justin. Danger on the Doorstep: Anti-Catholicism and American Print Culture in the Progressive Era. Notre Dame: U of Notre Dame P, 2006. Print

“November 22, 1963.” The Onion. Onion Inc. Issue 4147. 23 Nov. 2005. Web. 29 Jan. 2014. $<$ http://www.theonion.com/articles/november-22-1963,10584/>.

Obama, Barack. “Transcript: President Obama’s Convention Speech.” National Public Radio. 6 Sept. 2012. Web. 20 Jan. 2014. <http://www.npr.org/2012/09/06/160713941/transcriptpresident-obamas-convention-speech>.

O’Connor, Ryan. “"...you can beat us in the House of Assembly but you can't beat us on the street': The Symbolic Value of Charlottown's Orange Lodge Riot.” Historical Studies 72 (2006): 71-94. Print.

Ohmann, Richard. "Diverging Paths: Books and Magazines in the Transition to Corporate Capitalism." A History of the Book in America, Volume 4: Print in Motion: the Expansion of Publishing and Reading in the United States, 1880-1940. Ed. Carl F. Kaestle and Janice A. Radway Chapel Hill, NC: U of North Carolina P, 2009. 102-115. Print.

O’Leary, Stephen D. Arguing the Apocalypse: A Theory of Millennial Rhetoric. New York: Oxford UP, 1994. Print.

Olmsted, Kathryn S. Real Enemies: Conspiracy Theories and American Democracy, World War I to 9/11. New York: Oxford UP, 2009. Print. 
O’Malley, John. "Opening the Church to the World.” New York Times 10 October 2012: A31. Print.

Pagán, Victoria E. “Toward a Model of Conspiracy Theory for Ancient Rome.” New German Critique 103. 35.1 (Spring 2008): 27-49. Print.

Paterson, Frances R. A. Democracy and Intolerance: Christian School Curricula, School Choice, and Public Policy. Bloomington: Phi Delta Kappa Educational Foundation, 2003. Print.

“Patriotic Utterances of Patriotic Men.” A.P.A. Magazine 1.4 (Sept. 1895): 367-68. Print.Pauley, Garth. "Criticism in Context: Kenneth Burke's 'the Rhetoric of Hitler's 'battle." KB Journal. 6.1 (2009). Web. 4 February 2014. $<\mathrm{http}: / / \mathrm{kbjournal}$.org/content/criticism-context-kenneth-burkes-rhetoric-hitlers-battle> .

Paz, D. G. Popular Anti-Catholicism in Mid-Victorian England. Stanford: Stanford UP, 1992. Print.

Peterson, Merrill D. Lincoln in American Memory. New York: Oxford UP, 1994. Print.

Pfau, Michael W. "Who's Afraid of Fear Appeals? Contingency, Courage and Deliberation in Rhetorical Theory and Practice." Philosophy and Rhetoric 40.2 (2007): 216-237.

Phelps, Eric J. Vatican Assassins: "Wounded In the House of My Friends": The Diabolical History of the Society of Jesus Including: Its Second Thirty Years' War, 1914-1945, Its Cold War, 1945-1990, And Its Assassination of America's First Roman Catholic President, Knight of Columbus John Fitzgerald Kennedy (1963). Tehachapi, CA: Halycon Unified Services, 2001. Print.

Pipes, Daniel. Conspiracy: How the Paranoid Style Flourishes and Where It Comes From. New York: The Free Press, 1997. Print. 
Pittman, Coretta. "Black Women Writers and the Trouble with Ethos: Harriet Jacobs, Billie Holiday, and Sister Souljah.” Rhetoric Society Quarterly 37.1 (2007): 43-70. Print.

Pointer, Steven R. "American Postmillennialism: Seeing the Glory.” Christian History and Biography. Christianity Today 1 Jan. 1999 (61). Web. 9 March 2014. $<$ http://www.ctlibrary.com/ch/1999/issue61/61h028.html>.

Prokopowicz, Gerald J. "The Fatal Transition: From Lincoln to Johnson.” The Living Lincoln. Ed. Thomas A. Horrocks, Harold Holzer, and Frank J. Williams. Carbondale: Southern Illinois UP, 2011: 152-68. Print.

Prendergast, William B. The Catholic Voter in American Politics: The Passing of the Democratic Monolith. Washington, D.C: Georgetown University Press, 1999. Print.

Price, Warren E. "Editor's Innings. Aim of the A.P.A. Magazine." A.P.A. Magazine 1.2 (July 1895): front material, no page number. Print.

---. "Shop Talk." A.P.A. Magazine 1.6 (Nov. 1895): front material, no page number. Print.

---. "Small Talk." A.P.A. Magazine 1.4 (Sept. 1895): 403. Print.

---. "Where to Buy this Magazine." A.P.A. Magazine 2.2 (Jan. 1896): 834. Print. Public Policy Polling. "Republicans More Likely To Subscribe to Government Conspiracy Theories." National Survey Results. Raleigh, North Carolina: Public Policy Polling, 2 Oct. 2013. PDF.

Quinn, John F. “'The Nation's Guest?': The Battle between Catholics and Abolitionists to Manage Father Theobald Mathew's American Tour, 1849-1851." U. S. Catholic Historian 22.3 (Summer 2004): 19-40. JSTOR. Web. 8 July 2013.

Quintilian. Institutes of Oratory; or, Education of an Orator. In Twelve Books. Vol. 1. Trans. John Selby Watson. London: George Bell and Sons, 1907. Print. 
Raeburn, Daniel K., and Jack T. Chick. The Holy Book of Chick with the Apocrypha and Dictionary-Concordance. Chicago: IMP Publications, 1998. Print.

Ratzinger, Joseph and Jerome Hamer. "Declaration on Masonic Associations.” Rome: Office of the Sacred Congregation for the Doctrine of Faith, 26 Nov. 1983. Web. 9 July 2013.

Rausch, Jr., John David. “American Protective Association.” Conspiracy Theories in American History: An Encyclopedia. Peter Knight ed. Santa Barbara: ABC-CLIO, 2003. 58-59. Print.

Reed, Rebecca T. Six Months in a Convent, and Supplement. New York: Arno Press, 1977. Print.

Resner, André. Preacher and Cross: Person and Message in Theology and Rhetoric. Grand Rapids: William B. Eerdmans Pub, 1999. Print.

Reynolds, Nedra. "Ethos as Location: New Sites for Understanding Discursive Authority." Rhetoric Review 11.2 (1993): 325-38. Print.

Richards, Anne R, and Carol David. "Decorative Color As a Rhetorical Enhancement on the World Wide Web." Technical Communication Quarterly. 14.1 (2005): 31-48. Print.

Rivera, Alberto. "Foreword." Fifty Years in the Church of Rome. By Charles Chiniquy. Ontario, CA: Chick Publications, 1981. Print.

Rollins, Brooke. "Ghostwriting Ethos: Beyond Character and the Character Beyond." Diss. University of South Carolina, 2007. ProQuest. Web. 30 Apr. 2013.

Romsar, C. W. “Inside View of Rome's Superstitions. A Priest's Revelation.” A.P.A. Magazine 3.4 (Nov. 1896): 1555-59.

Ronald, Kate. "A Reexamination of Personal and Public Discourse in Classical Rhetoric." Rhetoric Review 9.1 (1990): 36-48. Print. 
Ronson, Jon. Them: Adventures with Extremists. London: Picador, 2008. Print.

Roy, Jody M. Rhetorical Campaigns of the Nineteenth-Century Anti-Catholics and Catholics in America. Lewiston: Edwin Mellen Press, 2000. Print.

"Rulers of Evil: Useful Knowledge about Governing Bodies." Rev. of Rulers of Evil: Useful Knowledge about Governing Bodies, by F. Tupper Saussy. Publisher's Weekly 25 June 2001. Web. 10 March 2014. < http://www.publishersweekly.com/978-0066210834>. Saussy, F. Tupper. Rulers of Evil: Useful Knowledge about Governing Bodies. New York: HarperCollins Publishers, 1999. Print.

Schmertz, Johanna. "Constructing essences: Ethos and the postmodern subject of feminism." Rhetoric Review 18:1 (1999): 82-91. Print.

Schrag, Peter. Not Fit for Our Society: Nativism and Immigration. Berkeley: U of California P, 2010. Print.

Schultz, Nancy Lusignan. Fire and Roses: The Burning of the Charlestown Convent. New York: The Free Press, 2000. Print.

Seguin, Peter A. Out of Hell and Purgatory: The Most Powerful Blow Ever Struck the Romish Hierarchy. Chicago: Militant Pub. Co, 1912. Print.

Serup, Paul. Who Killed Abraham Lincoln?: An Investigation of North America's Most Famous Ex-Priest's Assertion That the Roman Catholic Church Was Behind the Assassination of America's Greatest President. Prince George, B.C: Salmova Press, 2009. Print.

Shea, John G. A History of the Catholic Church Within the Limits of the United States: From the First Attempted Colonization to the Present Time with Portraits, Views, Maps and Facsimiles. Vol. 3. New York: J.G. Shea, 1890. Print.

Sherman, Allen B. and Edwin A. Sherman. "Sherman Was There: The Recollections of Major 
Edwin A. Sherman.” California Historical Society Quarterly 23.3 (Sept. 1944): 259-81. JSTOR. Web. 9 July 2013.

Sherman, Edwin A. The Engineer Corps of Hell: Or, Rome's Sappers and Miners. Containing the Tactics of the "militia of the Pope," or the Secret Manual of the Jesuits, and Other Matter Intensely Interesting, Especially to the Freemason and Lovers of Civil and Religious Liberty, Whithersoever Dispersed Throughout the Globe. San Francisco (?): n. p., 1883. Print.

Showalter, Elaine. Hystories: Hysterical Epidemics and Modern Media. New York: Columbia UP, 1997. Print.

“Six Lies Nailed (Compiled From Authoritative Sources).” Brooklyn: International Catholic Truth Society, 1914 (?). Print.

Slattery, Joseph. "Ex-Priests and the A.P.A.” A.P.A. Magazine 2.2 (Jan. 1896): 761-63. Print. ---. Secrets of Romish Priests Exposed. Cliftondale: Joseph Slattery, 1892. Print.

Smith, Craig. "Ethos Dwells Pervasively: A Hermeneutic Reading of Aristotle on Credibility." The Ethos of Rhetoric. Ed. Michael J. Hyde. Columbia: U of South Carolina P, 2004. 119. Print.

Smith, Ryan K. Gothic Arches, Latin Crosses: Anti-catholicism and American Church Designs in the Nineteenth Century. Chapel Hill, NC: University of North Carolina Press, 2006. Print.

Smith, Sydney F. Pastor Chiniquy: An Examination of His "Fifty Years in the Church of Rome.” London: Catholic Truth Society, 1908. Print.

Smith, Valerie J. "Aristotle's Classical Enthymeme And The Visual Argumentation Of The Twenty-First Century." Argumentation \& Advocacy 43.3/4 (2007): 114-123. 
MasterFILE Premier. Web. 9 Feb. 2014.

Stafford, Barbara M. Good Looking: Essays on the Virtue of Images. Cambridge: The MIT Press, 1996. Print.

Stauffer, Alvin P. Anti-Catholicism in American Politics, 1865-1900. Diss. Harvard, 1933. Print.

steelnvelvet. "Re: U.S. Civil War.” PrisonPlanet.com. Web. 11 March 2014. $<$ http://forum.prisonplanet.com/index.php?topic=25451.0; wap2>.

Steers, Jr., Edward. Lincoln Legends: Myths, Hoaxes, and Confabulations Associated with Our Greatest President. Lexington: U of Kentucky P, 2007. Print.

Steiner, Mark E. "The Lawyer As Peacemaker: Law and Community in Abraham Lincoln's Slander Cases." Journal of the Abraham Lincoln Association. 16.2 (1995): 1-22. Print.

Stephey, M. J. “Top 10 Memorable Debate Moments.” Time Magazine. n.d. Web. 21 Jan. 2014. $<$ http://content.time.com/time/specials/packages/completelist/0,29569,1844704,00.html $>$.

Strong, Josiah. Our Country: Its Possible Future and Its Present Crisis. New York: Published by Baker \& Taylor for the American Home Missionary Society, 1885. Print.

Swami, Viren et al. "Conspiracist ideation in Britain and Austria: Evidence of a monological belief system and associations between individual psychological differences and realworld and fictitious conspiracy theories." British Journal of Psychology 102 (2011): 443-63. Print.

Sweeting, Donald W. From Conflict to Cooperation?: Changing American Evangelical Attitudes Towards Roman Catholics: 1960-1998. UMI. ProQuest Dissertations and Theses, 1998. Print. 
Szymanski, Greg. “JFK's Hidden Agenda Speech Should Be Remembered: It Called Attention to the Jesuit and Vatican's New World Order Plan.” Investigative Journal Greg Szymanski. 30 Dec. 2010. Web. 28 Jan. 2014.

$<\mathrm{http}$ :/www.arcticbeacon.com/greg/headlines/jfks-hiden-agenda-speech-should-beremembered/>.

Taibbi, Matt. The Great Derangement: A Terrifying True Story of War, Politics, and Religion at the Twilight of the American Empire. New York: Spiegel \& Grau, 2008. Print.

The Assassination of Abraham Lincoln, Late President of the United States of America: And the Attempted Assassination of William H. Seward, Secretary of State, and Frederick W. Seward, Assistant Secretary, on the Evening of the 14th of April, 1865: Expressions of Condolence and Sympathy Inspired by These Events. Washington: Government Printing Office, 1867. Print.

“The Horrible Book.” A.P.A. Magazine 3.6 (March 1897): 1832. Print.

“The Moral Code of the Jesuits.” A.P.A. Magazine 1.1 (June 1895): 22-24. Print.

“The Pope's Encyclical. Lecture by Father Chiniquy.” Chicago Tribune 2 Nov. 1865. Vol. XIX. No. 154. Print.

Thompson, Richard W. The Papacy and the Civil Power. New York: Harper \& Brothers, 1876. Print.

“Three Assassins and Their History.” The Southern Guardian 10 Jan. 1914 (vol. 3, n. 44). Print.

Trudel, Marcel. Chiniquy. Trois Rivières: Editions du Bien Public, 1955. Print. Tumbleson, Raymond D. Catholicism in the English Protestant Imagination: Nationalism, Religion, and Literature, 1660-1745. Cambridge: Cambridge UP, 1998. Print. 
“Two Accounts of Father Chiniquy.” The Literary Digest 18.8 (Feb. 25, 1899): 227-28. Print. Van Horn, Chara Kay. The Paranoid Style in an Age of Suspicion: Conspiracy Thinking and Official Rhetoric in Contemporary America. Digital Archive@ GSU, 2010. Internet resource.

Ventura, Jesse, and Dick Russell. American Conspiracies: Lies, Lies, and More Dirty Lies That the Government Tells Us. New York: Skyhorse, 2011. Print.

Waldman, Steven. Founding Faith: Providence, Politics, and the Birth of Religious Freedom in America. New York: Random House, 2008. Print.

Walker, Jesse. The United States of Paranoia: A Conspiracy Theory. New York: HarperCollins Publishers, 2013. Print.

Wallace, George T. "A Word for the Ex-Priests.” A.P.A. Magazine 1.4 (Sept. 1895): 324. Print. Wallace, Les. The Rhetoric of Anti-Catholicism: The American Protective Association, 18871911. New York: Garland Pub, 1990. Print.

Warnick, Quinn. "What We Talk About When We Talk About Talking: Ethos at Work in an Online Community." Dissertation Abstracts International, Section A: the Humanities and Social Sciences. 71.9 (2011): 3256. Print.

"Washington.” Pullman Herald 28 Jan. 1899: 6. Print.

Watson, Thomas E. “The Romanists Cannot Afford to Fight Fair.” Watson's Magazine 15.5 (Sept.): 355-56. Print.

Weimann, David P. "Internet.” Conspiracy Theories in American History: An Encyclopedia. Peter Knight ed. Santa Barbara: ABC-CLIO, 2003. 347-49. Print.

Welter, Barbara. "From Maria Monk to Paul Blanshard: A Century of Protestant AntiCatholicism." Uncivil Religion: Interreligious Hostility in America. Ed. Robert N. 
Bellah and Frederick E. Greenspahn. New York: Crossroad, 1987. Print.

Westbrook, Steve. "Visual Rhetoric in a Culture of Fear: Impediments to Multimedia Production." College English. 68.5 (2006): 457-480. Print.

White, Horace. “Abraham Lincoln in 1854.” Putnam's Magazine (vol. 5) Mar. 1909: 723-29. Print.

White, Jr., Ronald C. A. Lincoln: A Biography. New York: Random House, 2009. Print.

Whitney, Henry C, and Paul M. Angle. Life on the Circuit with Lincoln. With Sketches of Generals Grant, Sherman and McClellan, Judge Davis, Leonard Swett, and Other Contemporaries. Boston: Estes and Lauriat, 1892. Print.

Wilcox, C T. The Transformation of the Republic: The Origins of the Religious Hi-Jacking of the American Government and the Truth Behind the Assassination of Abraham Lincoln. Calgary: Veracity, 2005. Print.

Williams, Linda S. "Strengthening the Ethics and Visual Rhetoric of Sales Letters." Business Communication Quarterly. 71.1 (2008): 44-52. Print.

Williams, Michael. The Shadow of the Pope. New York: Whittlesey House, McGraw-Hill Book Company, 1932. Print.

Wills, Garry. Head and Heart: American Christianities. New York: Penguin, 2007. Print.

Wilson, Douglas L. and Rodney O. Davis, ed. Herndon's Informants: Letters, Interviews, and Statements about Abraham Lincoln. Urbana: U of Illinois P, 1998. Print.

Woolf, Greg. Et Tu, Brute?: The Murder of Caesar and Political Assassination. Cambridge: Harvard UP, 2007. Print.

Yoos, George E. "A Revision of the Concept of Ethical Appeal." Philosophy \& Rhetoric. 12.1 (1979): 41-58. Print. 
Zanca, Kenneth J. The Catholics and Mrs. Mary Surratt: How They Responded to the Trial and Execution of the Lincoln Conspirator. Lanham, Md: University Press of America, 2008. Print.

Zarefsky, David. Lincoln, Douglas, and Slavery: In the Crucible of Public Debate. Chicago: U of Chicago P, 1990. Print.

--- “Abraham Lincoln, 'A House Divided': Speech at Springfield, Illinois (16 June 1858).” Voices of Democracy 6 (2011): 23-42. Web. 8 July 2013. $<$ http://www.voicesofdemocracy.umd.edu $>$. Zulick, Margaret D. "The Ethos of Invention: The Dialogue of Ethics and Aesthetics in Kenneth Burke and Mikhail Bakhtin.” The Ethos of Rhetoric. Ed. Michael J. Hyde. Columbia: U of South Carolina P, 2004. 20-33. Print. 


\section{CURRICULUM VITAE}

\section{MICHAEL JAMES SOBIECH}

\section{Education}

PhD in English, University of Louisville, Louisville, KY, expected May 2014

Dissertation: "The Ethos of Conspiracy Argument: 'Character' as Persuader in Conspiracy Rhetoric."

Committee: Debra Journet (Chair), Marilyn Cooper, Susan Griffin, Carol Mattingly, Bronwyn Williams.

MA in English, Western Kentucky University, Bowling Green, KY, 2008 Thesis: "A Mock Rhetoric: The Use of Satire in First-Year Composition." Committee: Dale Rigby (Chair), Jane Fife, Deborah Logan.

BS in Secondary Education, Indiana University, Bloomington, IN, 1988 Major: Social Studies

\section{Publications}

“A Critical Look at Robert Penn Warren's New (and old) Criticism on Satire.” $R P W$ : An Annual of Robert Penn Warren Studies. 9 (2012): 121-29.

\section{Awards, Honors, Grants}

John Richard Binford Memorial Award, 2014

University Fellow, University of Louisville, 2009-2010 \& 2012-2013

Western Kentucky University Yeager Scholarship (\$750), Fall 2008

Outstanding Graduate Student Award, Western Kentucky University Department of English, 2008-2009

Western Kentucky University Women's Studies Creative Writing Contest (Graduate Student Division), 2007

\section{Conference Presentations}

"The Illegitimacy of Roman Catholic Literacy: Nineteenth-Century Religious Conflicts and Contemporary Public Education." 2014 Conference on College Composition and 
Communication. Indianapolis. 22 March 2014.

"When (ex)Priests Lie About (dead) Presidents: The Religious/Political Fraud in Father Charles Chiniquy's Fifty Years in the Church of Rome." 2013 Conference on College Composition and Communication. Las Vegas. March 16, 2013.

“The Language of Mechanics." 2012 Thomas R. Watson Conference. Louisville. October 19, 2012.

"Using an Old Frame to Reframe a Gilded Age: Re-Constructing Post-Civil War American Identity via Antebellum Anti-Catholicism." 2012 Rhetoric Society of America Conference. Philadelphia. May 26, 2012.

Co-Presenter for "Better Materials, Better Thinking: How the Composition Program Helped Its Instructors to Emphasize Critical Thinking in Their Classrooms." 2012 Annual Ideas to Action (i2a) Institute: Critical Thinking Innovation. University of Louisville. May 22, 2012.

“Deerbrook's Dissent: Harriet Martineau's Non-Conforming Portrayal of NonAnglicans.” 2012 Modern Language Association. Seattle. January 7, 2012.

"When a Bear Wipes in the Woods: The Charmin Bears and the Rhetoric of the Taboo." 2011 Conference on College Composition and Communication. Atlanta. April 8, 2011.

"The Politics of Language at Work in E-mail.” 2010 Thomas R. Watson Conference. Louisville. October 15, 2010.

"Is that Elvis on the Grassy Knoll? Revisiting Critical Thinking by Rethinking Conspiracy Theories." 2010 Conference on College Composition and Communication. Louisville. March 18, 2010.

"(Funny Title Needed Here) The Use of Satire in Composition Pedagogy." 2009 Conference on College Composition and Communication. San Francisco. March 12, 2009.

"A Modest Proposal: How Satire Can Save the Universe (And Help Teach Rhetoric and Composition)." Humor Conference. Ohio University, October 4, 2008.

\section{Teaching}

Graduate Teaching Assistant, University of Louisville, 2009-2014

ENGL 101: Introduction to College Composition

ENGL 102: Intermediate College Composition

ENGL 306: Business Writing

ENGL 312: Survey of American Literature II

Adjunct Faculty, Western Kentucky University, Bowling Green, 2009

UC399: Conspiracy Theories and Pop Culture

ENG 100: Introduction to College Writing

ENG 300: Writing Across the Disciplines 
Instructor \& Substitute Instructor, English as a Second Language Institute, Bowling Green, KY, 2008-2009

Grammar, Reading, Speaking, and Writing classes

Graduate Teaching Assistant \& Graduate Assistant, Western Kentucky University, Bowling Green, 2007-2008

ENG 100: Introduction to College Writing

Writing Center Tutor.

\section{Administrative Experience}

Assistant Director of Composition

University of Louisville, Department of English

May 2011-May 2012

Henry James Fellow

University of Louisville, Department of English

August 2010-May 2012

\section{Professional Service \& Experience}

2013-2014 Paul Weber Award Selection Committee, University of Louisville (Graduate Student Representative)

First-Year PhD Student Mentor, 2010-2011, 2012-2013, \& 2013-2014

Research Assistant to the Chair of the Department of English, 2011-2013

Assessor for the University of Louisville's General Education Assessment Project for the General Education Curriculum Committee, September 2011 \& May 2012

Reviewer for Doug Downs \& Elizabeth Wardle's Writing about Writing: A College Reader (Bedford/St. Martin's, 2010), March 2012

Graduate Teaching Academy, Delphi Center, University of Lousville, 2011-2012

Executive Officer for the University of Louisville's English Graduate Student Organization, 2010-2011

Organized the University of Louisville's student chapter of the Rhetoric Society of America, Fall 2010

\section{Graduate Coursework}

Ph.D. University of Louisville

Politics of Language in the Study and Teaching of Composition (Bruce Horner)

Composition Theory and Practice (Min-Zhan Lu)

The Rhetoric of United States Slavery (Carol Mattingly) 
History of Rhetoric II (Carol Mattingly)

Research in Composition (Debra Journet)

Narrative Theory and Composition (Debra Journet)

Biology, Technology, and Writing (Marilyn Cooper)

Creative Nonfiction: Practices and Pedagogy (Bronwyn Williams)

Teaching College Composition (Joanna Wolfe)

Digital Media and Composition (Cindy Selfe \& Scott DeWitt, The Ohio State University)

Genre Studies: Film (Bronwyn Williams)

Sexuality and Aesthetics (Matthew Biberman)

M.A. Western Kentucky University

The History of Rhetoric (John Hagaman)

Theories of Rhetoric and Composition (John Hagaman)

Writing Center Practicum (Jane Fife)

Graduate Writing Workshop (Dale Rigby)

Graduate Rhetoric and Writing (David LeNoir)

Victorian Literature (Deborah Logan)

Shakespeare II (Elizabeth Oakes)

Literary Theory (Niko Endres)

Women's Fiction (Jane Olmsted)

\section{Professional Affiliations}

Conference on College Composition and Communication

Modern Language Association

National Council of Teachers of English

Rhetoric Society of America

Council of Writing Program Administrators

International Society for the History of Rhetoric

\section{References}

Debra Journet, Professor

Department of English, University of Louisville

Bronwyn Williams, Professor and Director of the Writing Center

Department of English, University of Louisville

Susan Griffin, Professor

Department of English, University of Louisville

Carol Mattingly, Professor

Department of English, University of Louisville 